UNIVERSIDADE DE SÃO PAULO

FACULDADE DE ARQUITETURA E URBANISMO

Curso de Pós-Graduação em Arquitetura e Urbanismo

\title{
CONTRIBUIÇÃO PARA O PROJETO URBANO ANHUMAS CAMPINASISP
}

PEDRO PAULO DE SIQUEIRA MAINIERI

São Paulo

2008 
UNIVERSIDADE DE SÃO PAULO

FACULDADE DE ARQUITETURA E URBANISMO

Curso de Pós-Graduação em Arquitetura e Urbanismo

\section{CONTRIBUIÇÃO PARA O PROJETO URBANO ANHUMAS CAMPINASISP}

PEDRO PAULO DE SIQUEIRA MAINIERI

Dissertação apresentada à
Faculdade de Arquitetura e
Urbanismo como parte dos
requisitos para obtenção do
título de Mestre em Arquitetura
e Urbanismo na área de
concentração de Projeto de
Arquitetura.

Orientador: Prof. Dr. Adilson Costa Macedo

São Paulo 
Ficha catalográfica pelo Depto de Arquitetura e Urbanismo da FAU USP

Mainieri, Pedro Paulo de Siqueira.

Contribuição para o Projeto Urbano Anhumas - Campinas/SP / Pedro Paulo de Siqueira Mainieri - São Paulo: FAU USP, 2008. $140 \mathrm{p}$.

Dissertação (Mestrado) - Universidade de São Paulo, 2008.

1. Projeto Urbano. 2. Operação Urbana, 3. Vazio Urbano. I. Título 
Dedico este trabalho ao futuro de Campinas, representado pelo meu filho João Pedro. 


\section{AGRADECIMENTOS}

Ao Prof. Dr. Adilson Costa Macedo, meu orientador, por ter acompanhado todo o desenvolvimento do meu trabalho, dando o direcionamento decisivo dos rumos a serem seguidos.

Agradeço a imensa contribuição dos professores Dr. Jorge Bassani e Dr. Paulo Bruna, na banca de qualificação, contribuindo com comentários para que eu pudesse ainda mais melhorar a pesquisa.

Aos meus pais Fernando e Wilma, pelo grande incentivo desde o início.

Aos meus irmãos Paulo e Luiz Fernando que me auxiliaram na formatação dos textos e imagens gráficas, sendo que os mesmos foram decisivos para conclusão desta tese.

À minha esposa Aline, por seu companheirismo e amor durante todo o período, tanto nos momentos tranqüilos como nos mais conturbados.

Aos funcionários das bibliotecas da FAU USP e FAU Puccamp, que viabilizaram a coleta do material para subsidiar este trabalho. 


\section{RESUMO}

Esta dissertação consiste em uma contribuição ao estudo de caso Projeto Urbano Anhumas em Campinas - SP, situado nas bordas do anel viário do centro expandido, em área de vazio urbano formado pela desativação do leito ferroviário, no ponto onde se forma o ribeirão Anhumas. Com o objetivo de propor diretrizes para a re-integração da área ao tecido urbano do entorno, considera o desenvolvimento urbano, a formação histórica da morfologia da cidade, bem como o estudo dos aspectos legais, ambientais e da dispersão urbana. A análise se dá nas escalas local e metropolitana, sob a perspectiva do desenvolvimento de novas centralidades situadas ao longo das antigas ferrovias. Tem como pano de fundo as recentes teorias do urbanismo contemporâneo, analisadas através de casos concretos das experiências nacionais e internacionais, confrontadas com a realidade local.

Palavras-Chave: Projeto Urbano, Vazio Urbano, Operação Urbana, Campinas, Anhumas

\section{ABSTRACT}

This dissertation consists of a contribuition to the case study of the Projeto Urbano Anhumas in Campinas - SP, located at the outskirts of the beltline of the expanded center of the city, in a vacant urban area created by the desactivation of the railroad bed at the point where the Anhumas stream is formed. With the objective of recommending procedures for the re-integration of the surronding urban mesh, it considers the urban development, the historical upbringing ot the city's morfology, as well as the study of the legal and environmental aspects, and of the urban dispersion. The analysis occurs on local and metropolitan scenario, under the perspective of the development of settelments situated along the old railroad. It has a background on recent theories on contemporary urbanism, analyzed through real cases of national and international experiences, confronted with the local reality.

Key-Words: Urban Project, Vacant Urban, Urban Operation, Campinas, Anhumas 


\section{SUMÁRIO}

INTRODUÇÃO

1. CAPITULO 1 - PROJETO URBANO: PANORAMA TEÓRICO E PRÁTICO............9

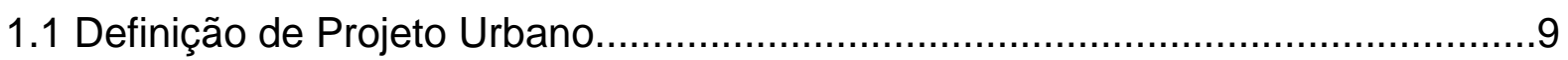

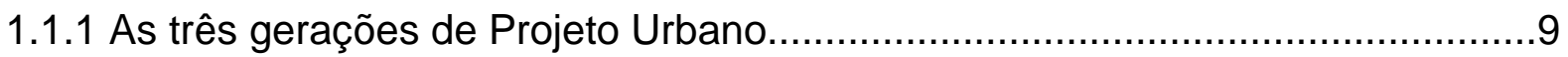

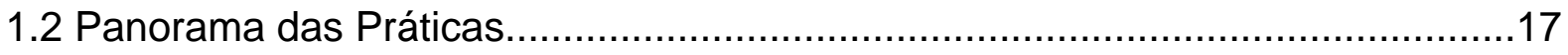

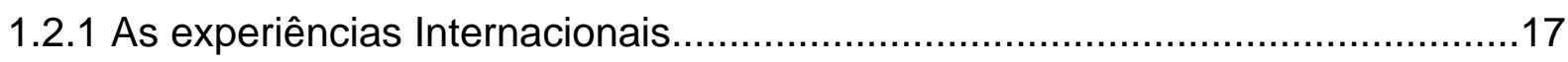

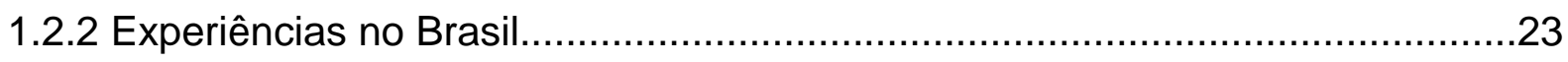

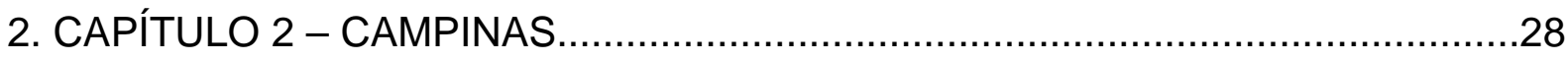

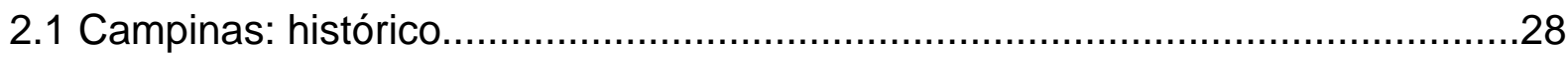

2.1.1 Análise da configuração da morfologia da área de estudo..............................37

2.2 Campinas Contemporânea: leitura na escala metropolitana...................................45

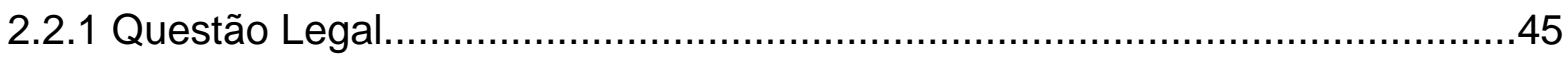

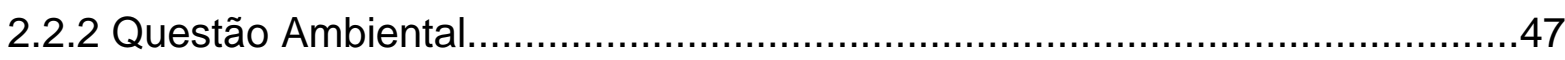

2.2.3 Questão da Urbanização Dispersa.........................................................52

3. CAPÍTULO 03 - ESTUDO DE CASO:

CONTRIBUIÇÃO AO PROJETO URBANO ANHUMAS......................................56

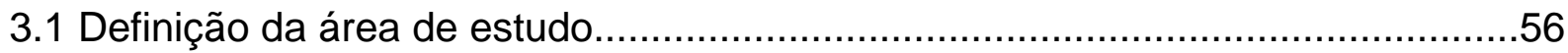

3.2 Configuração da estruturação urbana atual -

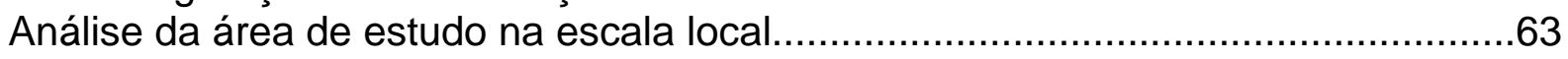

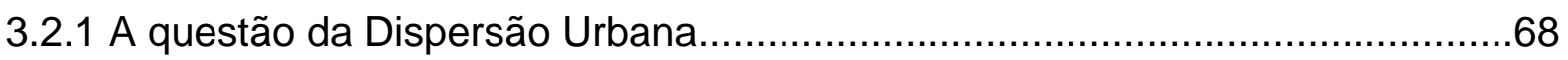

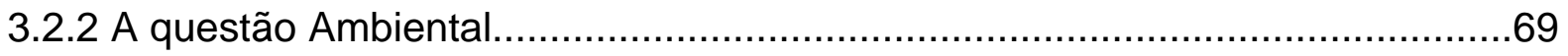

3.2.3 A questão da Legislação.......................................................................

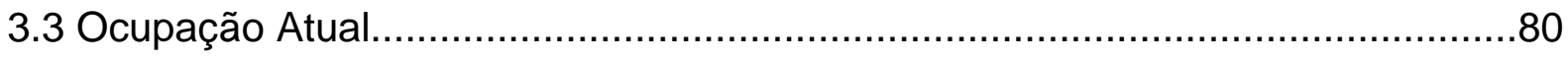

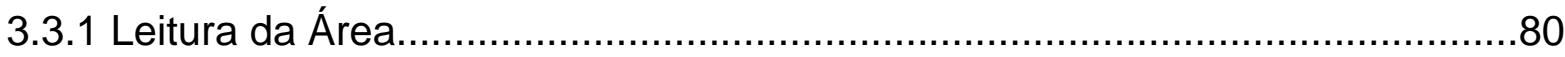




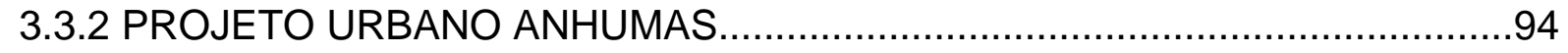

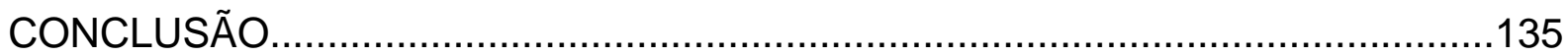

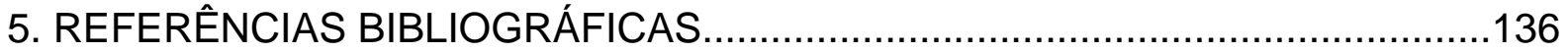




\section{INTRODUÇÃO}

A cidade de Campinas apresenta uma realidade dual. Por um lado configura-se como um pólo industrial de alta tecnologia, referência na área de saúde e como um importante centro universitário e de pesquisas, além de sua infra-estrutura rodoviária e aeroportuária. Por outro lado, como a maioria das grandes cidades brasileiras, apresenta um quadro de desigualdade social e desenvolvimento urbano desordenado, com conseqüente impacto ambiental e com problemas na infra-estrutura de transportes.

Uma das alternativas propostas pelo poder público, visando a integração dessas duas realidades é a criação de novas centralidades, situadas em vazios urbanos degradados ao longo dos eixos ferroviários.

A área de estudo analisada nesse trabalho é um desses vazios e se apresenta num contexto de fragmentação do tecido urbano, com descontinuidade do sistema viário e degradação ambiental. Por outro lado a área apresenta grande potencial de desenvolvimento devido ao interesse da iniciativa privada na região e a sua localização, entre o centro expandido e o anel viário externo.

A dissertação tem como objetivo contribuir com as diretrizes urbanísticas que visam o desenvolvimento e ocupação da área de estudo, apresentadas sob a forma de um Projeto Urbano.

Visando o melhor entendimento da proposta, a dissertação foi dividida em três capítulos.

No primeiro capítulo traçou-se um panorama sobre as teorias do urbanismo contemporâneo, refletidas nas análises de casos das experiências práticas nacionais e internacionais.

O segundo capítulo parte de um breve levantamento histórico do desenvolvimento sócio-econômico e urbano da cidade de Campinas, do período desde a fundação até a cidade contemporânea e aprofunda-se no estudo dos aspectos legais, ambientais e referentes à dispersão urbana, na escala metropolitana.

O conteúdo levantado nesses dois momentos serve de base para o desenvolvimento do estudo de caso apresentado no capítulo 3.

A leitura da realidade local e da metropolitana se consolidam como o Projeto Urbano Anhumas .

\section{CAPITULO 1 - PROJETO URBANO: PANORAMA TEÓRICO E PRÁTICO}

Nesse capítulo pretendo resumir o contexto histórico urbanístico, principalmente do período pós-segunda guerra até os dias de hoje, influenciado pelas transformações sociais e econômicas, com o objetivo de evidenciar a transição do Planejamento Urbano para a prática de projeto urbano.

\subsection{Definição de Projeto Urbano}

Segundo a definição de Cândido Malta e Nádia Someck, entende-se por projetos Urbanos as iniciativas de renovação urbana concentradas em determinados setores da cidade, 
combinando agentes públicos e privados, cujos investimentos e intervenções seguem um plano urbanístico, podendo se apoiar no redesenho do espaço urbano e arquitetônico, em normas legais específicas e em novas articulações institucionais e formas de gestão ${ }^{54}$.

\subsubsection{As três gerações de Projeto Urbano}

Visando facilitar o entendimento do desenvolvimento da idéia de projeto urbano, seguirei a abordagem de Carlos Leite que aborda essa questão em três gerações.

\section{A Primeira Geração}

A primeira Geração pretende configurar de forma exemplar o que deveria ser a cidade moderna. Caracteriza-se através de projetos de grande dimensões e complexidade. Desde 1914, com a criação de habitações coletivas moderna, em Amsterdã Sul por Berlage, até a construção de cidades novas.

Os conceitos da primeira geração ganham maior expressão com a Carta de Atenas em 1933, porém, somente no período pós-guerra é que encontrarão demanda para as realizações parciais na Europa ${ }^{55}$.

A Carta de Atenas propunha regras objetivas para a reconstrução das cidades baseadas no racionalismo, setorizando as cidades em 4 atividades: trabalhar, lazer, circular e habitar.

Nas primeiras décadas do pós-guerra, a Europa experimenta um momento de forte crescimento econômico, coexistindo com a reconstrução da maioria das suas grandes cidades. Dentro desse panorama coube ao Planejamento o papel de organizar os espaços das cidades, através de planos reguladores e orientadores do solo.

Segundo Benfatti, o processo de discussões envolvendo o crescimento e a transformações das cidades, o planejamento urbano e as propostas de contenção e de redistribuição equilibrada da população no território urbano e regional incidirá de maneira decisiva na formulação do Plano da Grande Londres (1944). Também o ato que viabilizaria a política de New Towns na Inglaterra, editado em 1946, baseou-se nesta discussão onde a Town and Country Planning Association teve papel fundamental, em seu papel de oposição sistemática à criação dos novos subúrbios. Defendia, como alternativa, a criação de cidades novas autônomas. Foi proposto um reassentamento populacional em oito cidades novas, auto-suficientes, localizadas a uma distância média de $50 \mathrm{~km}$ do centro de Londres, com objetivo, entre outros, possibilitar a desconcentração industrial e residencial e a diminuição da população da grande Londres em seu conjunto. Esta estratégia de contenção de crescimento, através de cidades novas, foi seguida posteriormente por

\footnotetext{
${ }^{54}$ CAMPOS, Candido Malta; SOMECKH Nádia. Desenvolvimento Local e projetos urbanos Artigo apresentado no IX Encontro nacional da ANPUR. Ética, Planejamento Urbano e Construção democrática do Espaço (tema: Escalas de poder e novas formas de gestão urbana e regional) e disponibilizado em 08.2004.

55 SOUZA, Carlos Leite de. Fraturas Urbanas e a possibilidade de novas territorialidades metropolitanas: A Orla Ferroviária Paulistana. Tese de Doutorado, FAU USP, São Paulo, 2002.
} 
diversos países. Primeiramente nos países escandinavos, em Helsinki e Estocolmo, no início da década de 50. Em seguida no Japão, nos moldes do modelo inglês, com o Plano para a Grande Tóquio, contando com um cinturão verde rodeado por novas cidades. Esta abordagem também foi proposta na Rússia, França, Estados Unidos e vários outros países, inclusive tardiamente no Brasil, nos anos 70 , com as políticas de contenção adotadas nos programas de cidades médias e regiões metropolitanas, da qual o caso de Campinas é de interesse a este trabalho ${ }^{56}$.

Os grandes conjuntos habitacionais construídos em várias cidades européias também são exemplos dos ideais modernistas, que têm a cidade de Brasília como um dos maiores exercícios urbanísticos de inspiração corbusiana. Para se ter uma idéia da profundidade da crise habitacional européia no pós-guerra, na cidade de Paris, segundo Benfatti, em 1954, apenas 22\% das habitações possuíam sistema de abastecimento de água corrente, cerca de $40 \%$ não possuíam lavabo interno e apenas 20\% possuíam banheiros com ducha ${ }^{57}$. Num período de 15 anos, entre 1955 e 1970, foram edificados mais de 4 milhões de apartamentos em toda a França, sem contar milhares de habitações individuais ${ }^{58}$.

A visão abstrata das propostas da cidade funcionalista, contida na Carta de Atenas e edificada, foi criticada a partir de 1951, no VII Congresso CIAM (Congresso Internacional de Arquitetura Moderna), na cidade de Hoddeston (GB). Surge a segunda geração de projetos urbanos.

\section{A Segunda Geração}

Segundo Bassani, a nova geração de arquitetos não tinha mais a ilusão que a lógica maquinista e uniformizadora poderia dar conta de solucionar os grandes conflitos da cidade do pósguerra e propõe um "core" da cidade mais local e comunal.

Em 1956, no X CIAM, ocorre a ruptura com o pensamento da época através das propostas do Team $X$, que criticam a ausência das relações humanas na cidade funcionalista ${ }^{59}$.

Segundo Leite, o termo "desenho urbano" surge na década de 60 para identificar um campo disciplinar, na escola anglo-saxã, com a proposição de metodologias alternativas que consideram as necessidades e vontades das populações locais.

O Urbanismo resultante era crítico às propostas autorais e generalistas do planejamento urbano moderno.

Nesta década, diversos autores desenvolveram metodologias para dotar os projetos das dimensões urbanas e humanas, perdidas com as grandes intervenções modernistas ${ }^{60}$. Destacam-se os autores: Kevin Lynch, Jane Jacobs, Gordon Cullen e Aldo Rossi.

${ }^{56}$ BENFATTI, Denio Munia. Nome artigo em negrito; in: Revista Óculum 9 - Ed. Agosto 1997, Publicação da Fau Puccamp. p. 18

${ }^{57}$ Ibid, p.18

58 LE DANTEC Jean Pierre. En fin l'Architecture - Autrement, Paris 1984. p 33, in BENFATTI, Denio Munia. Nome artigo em negrito; in: Revista Óculum 9 - Ed. Agosto 1997, Publicação da Fau Puccamp. p. 18.

${ }^{59}$ BASSANI Jorge. A função é a comunicação. Tese de Doutorado, FAU USP, São Paulo, 2005.

${ }^{60}$ SOUZA, op. cit 
Segundo Bassani, Kevin Lynch, em 1960, publica o livro "A imagem da cidade", pelo Massachusetts Institute of Technology, resultado de pesquisas com os habitantes de três cidades norte americanas: Boston, Los Angeles e Jersey City. Através da análise qualitativa da relação do homem com o ambiente urbano, baseados na imagem que o usuário urbano faz da cidade, Lynch baliza novas formas de interpretação da cidade que fundamentam os projetos, como a revitalização urbana em Boston.

Jane Jacobs, em 1961, lança o livro "Morte e vida de grandes cidades", atacando o planejamento moderno e propondo novos princípios para o planejamento urbano e reurbanização, chamando fortemente a atenção para estes temas ${ }^{61}$.

Segundo Josep Maria Montaner, "Morte e vida de grandes cidades" constituiu uma das primeiras críticas abertas ao urbanismo moderno, demonstrando que onde existe mais vida social, mais relação entre as pessoas e, inclusive, mais segurança, é nos tecidos da cidade tradicional" ${ }^{\prime 62}$.

Ainda em 1961, Gordon Cullen publica "Paisagem Urbana", reunindo artigos publicados por ele na revista "The Architectural Review". Apresenta uma metodologia baseada a partir da experiência pessoal e estruturada pelo desenho. Trabalha com o específico da paisagem, sistematizando-as, classificando-as e identificando-as como acontecimentos especiais que organizam o pensamento projetual para o urbano. Utiliza como referência, as cidades antigas, principalmente italianas, para criticar a ausência de ambiente sensível do funcionalismo moderno.

Em 1966, Aldo Rossi publica "A Arquitetura da cidade". Segundo Montaner:

"Arquitetura da cidade" se converteu no fundamento teórico das interpretações contemporâneas que entende a cidade como lugar da complexidade, de memória urbana, de tantos elementos irredutíveis e irracionais. (...) A tese básica é a interpretação da cidade como fenômeno cultural, humano, econômico e geográfico de uma extrema complexidade.(...) O livro é um argumento contra a pretensão de uma interpretação exclusivamente racionalista e quantitativa da complexidade urbana"63.

Segundo Bassani, "A arquitetura da cidade" coloca em discussão um importante tema ao ambiente urbano: o "lócus".

O "lócus" urbano seria a expressão de coletivos ao longo da história, identificável pela memória coletiva, revalorizando as qualidades de ambiente multisensorial ${ }^{64}$.

O conceito de espaço funcionalista; abstrato, matemático, projetual e contínuo, é confrontado pela idéia de lugar: "aquela relação singular mas universal entre certa situação local e as construções que se encontram naquele lugar, ${ }^{\prime \prime 5}$.

\footnotetext{
${ }^{61}$ BASSANI, op.cit.

62 MONTANER, Josep Maria. A modernidade superada, ed Gustavo Gilli S.A..Barcelona 2001.p. 158.

63 Ibid.,p.
} 


\section{A Terceira Geração}

Segundo Leite, a terceira geração de projetos urbanos surge a partir da década de 70, quando o panorama econômico global entra em crise, exigindo novas concepções de planejamento e gestão de cidades em decorrência do surgimento de grandes áreas nas cidades industriais ${ }^{66}$. Conforme Maricato e Whitaker Ferreira:

"Já na década de 70, inicia-se na Europa e nos EUA um processo paulatino de déficit de arrecadação do Estado, devido a problemas como o aumento do desemprego, o alto custo de manutenção do Estado-Providência e a crise fiscal, todos relacionados com as transformações paradigmáticas geradas pela reestruturação produtiva e o esgotamento do modelo fordista-taylorista. Por esta razão, ganharam força política visando a uma co-responsabilização da gestão das cidades por todos os agentes participantes da produção do espaço urbano"67.

Esse momento de reestruturação econômica é o que Harvey nomeia de "passagem do fordismo para a acumulação flexível", conforme as citações abaixo:

"A transição do sistema de produção fordista, fortemente dependente de fatores locacionais e respaldado pelo Estado do bem-estar keynesiano, para formas de acumulação flexíveis, muito mais abertas geograficamente e baseadas no mercado"68.

"A acumulação flexível, como vou chamá-la, é marcada por um confronto direto com a rigidez do fordismo. Ela se apóia na flexibilidade dos processos de trabalho, dos mercados de trabalho, dos produtos e padrões de consumo. Caracteriza-se pelo surgimento de setores de produção inteiramente novos, novas maneiras de fornecimento de serviços financeiros, novos mercados e sobretudo, taxas altamente intensificadas de inovação comercial, tecnológica e organizacional. A acumulação flexível envolve rápidas mudanças nos padrões do desenvolvimento desigual, tanto entre

\footnotetext{
${ }^{64}$ BASSANI, op. cit.,

${ }^{65}$ ROSSI, Aldo. A Arquitetura da Cidade. São Paulo, M. Fontes, 1995.p.18

${ }^{66}$ SOUZA, op. cit.,

67 MARICATO Ermínia e FERREIRA João Sette Whitaker, Operação Urbana consorciada: diversificação urbanística participativa ou aprofundamento da desigualdade?, p. 81
} 
setores como entre regiões geográficas, criando por exemplo, um vasto movimento no emprego no chamado "setor de serviços", bem como conjuntos industriais completamente novos em regiões ate então subdesenvolvidas"69.

Essa transição implica na modificação do papel do Estado e na gestão das cidades, passando do gerenciamento ao empresariamento, conforme afirma Harvey: "(...) a abordagem do gerenciamento, tão típica dos anos sessenta, deu prontamente lugar a formas de ação de empresariamento dos anos setenta e oitenta" ${ }^{\prime 70}$.

O poder público passa a incentivar ou mesmo se associar ao desenvolvimento privado e a função do Planejamento também muda. Os agentes sociais envolvidos nesse processo têm sua força e seu peso alterados diante dessa nova esfera de negociação das questões urbanas. Conseqüentemente, os planos e projetos urbanos também sofrerão alterações, quer na escala, quer nas características e pontos relevantes de intervenção, como afirma Nobre:

"Observou-se que as modificações no paradigma de
desenvolvimento têm causado uma série de conseqüências na
estruturação territorial das cidades e regiões. A transferência das
atividades manufatureiras, o crescimento dos fluxos de
investimentos e informações em nível mundial, possibilitados pelo
novo paradigma tecnológico, tem ocasionado a decadência e a
ascensão de diferentes regiões do mundo"71.

Em decorrência desse cenário, as cidades passam a competir entre si pelos novos investimentos, com novas formulações de urbanismo, entre elas o "marketing urbano", segundo Harvey:

"As cidades atualmente parecem estar prestando mais atenção em criar uma imagem positiva e de alta qualidade, e tem procurado uma arquitetura e formas de desenho urbano que respondam a essa necessidade (...) com poucas opções além de competir umas com

\footnotetext{
${ }^{68}$ HARVEY, David, A condição Pós Moderna, p.58.

${ }^{69}$ HARVEY, David. Do gerenciamento ao empresariamento: a transformação da administração urbana no capitalismo tardio. p. 49 Originalmente escrito em inglês e publicado em Geografiska Annaler 71B (1989) p.3-17.

Espaço e Debates - Numero 39-1996 p.49-64.

${ }^{70}$ Ibid.p.

${ }^{71}$ NOBRE, Eduardo A. Cusce. Reestruturação econômica e território: Expansão recente do terciário na marginal do rio Pinheiros. Doutorado FAU USP Agosto de 2000-SP p. 91
} 
as outras, principalmente como centros financeiros, de consumo e de entretenimento"72.

Segundo Carlos Leite, a partir dos anos 80, aparecem as intervenções urbanas de maior porte para nas metrópoles contemporâneas, inseridas neste contexto sócio-econômico e cultural. Ocorre a substituição do termo "desenho urbano" pelo termo "projeto urbano", refletindo a nova e complexa lógica dos projetos de partido conceitual inovador para a construção de novas territorialidades. A principal diferença entre a terceira geração e as primeiras, não é de dimensão nem de composição funcional dos projetos urbanos e sim da complexidade da dinâmica do território metropolitano contemporâneo.

Entra em cena o planejamento estratégico ao qual se vinculam os projetos urbanos ${ }^{73}$. Conforme Borja e Castells, os principais objetivos das atuações estratégicas são os que permitem melhorar a acessibilidade, integração e mobilidade do espaço urbano, com as cidades buscando melhores condições de competitividade através de uma visão a longo prazo e da modernização física e administrativa ${ }^{74}$.

Segundo Leite, a questão da capacidade executiva e de dinamizar trechos da cidade é expressão do planejamento estratégico ${ }^{75}$.

Conforme Maricato e Whitaker Ferreira, o planejamento estratégico tem uma bem sucedida aceitação por ser uma possibilidade de flexibilização da legislação modernista/funcionalista, pois: "Regras que pretendiam dar conta da normatização o uso do solo em todo o território urbano, desconhecendo, frequentemente, especificidades espaciais, sociais e ambientais, foram perdendo paulatinamente prestígio"76.

Conforme Leite, os planos estratégicos seguem três princípios: os objetivos urbanos são definidos de acordo com as dinâmicas em curso, a relação entre os objetivos, os projetos e os impactos, e a participação dos agentes públicos e privados em todas as fases do processo.

Os processos urbanos podem ser de três tipos: metástase urbana, com a intervenção integrada ao entorno imediato, gerando efeitos transformadores; buscando o equilíbrio entre o câmbio de atividades, usos e populações dos tecidos sociais da área da intervenção urbana; e dinamizando econômica, física e culturalmente, a totalidade ou uma parte da cidade.

Pode-se ainda dividir as intervenções em relação à escala: grande, intermediária e menor. A grande escala de intervenção atende aos objetivos econômicos, sociais e culturais propostos; e deve ser coerente com outras intervenções no território, gerar o efeito da metástase urbana no entorno além de gerar iniciativas que reforcem seu potencial. A escala intermediária, corresponde a intervenções de renovação, de promoção de novos pólos ou novas centralidades e

\footnotetext{
${ }^{72}$ HARVEY, David. A condição Pós Moderna, p.58.

${ }^{73}$ SOUZA, op. cit.

${ }^{74}$ BORJA, J. e CASTELLS, M. As cidades como atores políticos. Novos Estudos CEBRAP, n. 45, jul. 1996, p.152-166.

${ }^{75}$ SOUZA, op. cit., $p$

${ }^{76}$ MARICATO, op. cit., p 81
} 
deve também se relacionar com outras intervenções paralelas de forma coesa e complementar. A escala menor se refere às situações pontuais e mesmo assim mantém vínculo com o desenvolvimento urbano de acordo com os efeitos que causar na dinâmica metropolitana ${ }^{77}$.

\subsection{Panorama das Práticas}

\subsubsection{As experiências Internacionais}

As experiências internacionais de implementação de projetos urbanos são tão variadas quanto diversificadas. Como aprofundamento das questões abordadas, será estudada uma pequena parte dos chamados "Grandes Projetos Urbanos", elaborados a partir da década de 80. 0 recorte da leitura resumida de alguns casos destes, em tão amplo panorama mundial, se deve às seguintes classificações, redutoras porém didáticas: Battery Park, em Nova York, como a primeira ação deste porte, Vila Olímpica em Barcelona, reconhecidamente como a experiência mais bem sucedida em termos urbanísticos e sócio-econômicos, e a experiência de Bercy-Rive Gauche, em Paris, pelas possíveis similaridades - em escala, mix funções e partido urbanístico - com a proposta apresentada como estudo de caso no capítulo 03.

\section{O caso de Nova York}

Segundo Bassani, o Battery Park City, em Nova York, é uma área de 37 hectares situada às margens do Rio Hudson, no extremo sudoeste da ilha de Manhattan. Situada junto ao sítio original de Nova York e onde hoje se encontra um dos principais complexos financeiros mundiais, o Downtown, abrigava o porto da cidade, entre armazéns e linhas ferroviárias e pátios de manobra.

Com a transferência do porto, nos anos 60, a área entra em processo de decadência. È nessa época que a área é utilizada como local de descarga de entulhos das obras das torres do World Trade Center. A área do antigo porto, acrescida do terreno criado pelos aterros, possuía um grande potencial de expansão do centro financeiro.

Desde os anos 70, quando da construção das torres do World Trade Center, já havia um plano de ações para a área, porém os projetos não tiveram continuidade. Em 1979, foi criado o Battery Park City Authority para estabelecer um plano e recuperação da gleba, configurando-se como uma das primeiras ações urbanas características que vieram a caracterizar o final do século.

O plano inicial de Alexander Cooper e Stanton Eckstut, determina os critérios de ocupação e usos, apontando soluções típicas como a mistura de usos, a valorização dos espaços públicos e a qualificação paisagística.

Os objetivos são: reintegrar a área à cidade - como extensão do centro financeiro, configurar o novo "waterfront" do sul da cidade, principalmente para quem vem de Long Island e se tornar um referencial simbólico para toda a cidade. As seis torres do World Financial Center,

\footnotetext{
${ }^{77}$ SOUZA, op. cit
} 
projetadas pelo arquiteto César Pelli e inaugurados em 1988 se configuram como grande ponto focal, simbólico e paisagístico de todo conjunto.

Como a estruturação viária se dá somente pela West street, a integração fica comprometida, pois a avenida se configura como barreira, apenas transposta por passarelas. Esta situação, em conjunto com o fato da iniciativa privada assumir totalmente o empreendimento, tornam o conjunto como uma "bolha urbana". Espaços públicos pouco freqüentados configuram a área como valor simbólico urbano, e não como valor de uso público ${ }^{78}$.

\section{O caso Europeu: Paris e Barcelona}

\section{O caso de Paris}

Segundo Maricato e Whitaker Ferreira, a legislação francesa das ZACs(Zones D’Ámenagement Concertée - trauzida por Zona de Renovação Concensual), de 1967 e aplicada nos anos 70 e 80, estabelece um marco regulatório, coordenando as ações dos diversos agentes envolvidos na renovação de áreas antigas ou implantação de grandes equipamentos. As terras em áreas degradadas são adquiridas pelo Estado, que decide seu uso e pode até, em alguns casos, fazer o projeto do edifício a ser construído no local. Os equipamentos públicos são negociados com os órgãos responsáveis. A iniciativa privada compra as áreas de escritórios ou estabelecimentos comerciais gerando os recursos que amortizam financeiramente a operação e garantem a oferta de moradias $^{79}$.

Um exemplo de utilização da ZAC é o projeto Bercy-Rive Gauche, em Paris. Segundo Bassani, em Paris, na década de 70 , os esforços urbanísticos estão concentrados no Centro e no extremo oeste, em La Defense, reforçando a cidade qualificada pelo Louvre e pela Champs Elysées. A zona Sudeste e Leste permanecem em alto grau de deteriorização. As grandes áreas dos pátios ferroviários ao longo do rio Sena, assim como a presenca de armazéns e fábricas desativadas passar a ser objeto de estudos pelo APUR (Ateliê Parisiense de Urbanismo) somente na década de 80.

Em 1988 é lançado o plano de J.P. Buffi e M. Macary para o bairro de Bercy, na margem norte.Uma área de 54,5 hectares foi declarada Zona de Renovação Consensual (ZAC), com o objetivo criar um novo bairro, articulado por um parque de 13 hectares (objeto de concurso vencido pela equipe de $B$. Huet).

O parque, de configuração retangular, às margens do Sena, tem, em uma cabeceira, um complexo esportivo. Na outra ponta, um grande centro de comércio, serviços e lazer. Ao longo do parque estão instaladas habitações e equipamentos escolares.

\footnotetext{
${ }^{78}$ BASSANI, op. cit.

${ }^{79}$ MARICATO, op cit., p. 81.
} 
As intervenções citadas relacionam grandes equipamentos com premissas opostas às do urbanismo funcionalista moderno. Configura-se a "cidade do passeio" com foco no pedestre, onde as relações entre os espaços construídos e verdes dos desenhos das quadras de Tolbiac se articulam com equipamentos em diversas escalas: municipal, metropolitana e até internacional, como no caso da Biblioteca Miterrand. Em outro momento ocorre a convivência entre as grandes estruturas (como o Complexo Esportivo) e as tipologias mantidas, como no caso dos moinhos requalificados e do mercado de peixe.

Na margem sul, o plano Seine Rive Gauche de 1992 apóia-se numa ZAC de 130 hectares. Dividida em três bairros, Auterlitz - projeto de C. Devillers, Tolbiac - de R. Schweitzer e Massena - de C. Portzamparc, têm como epicentro a Biblioteca François Miterrand, projetada por D. Perrault em 1997. Com capacidade para 12 milhões de volumes e 5 mil lugares de leitura, a Biblioteca inscreve-se nas estratégias dos "grandes trabalhos" de Miterrand, recolocando a cultura como principal produto francês.

Os três blocos de intervenções são articulados pela Avenue de France, transformada em espaço público linear semelhante a uma rambla.

Auterlitz compõe-se de um centro de escritórios corporativos. Em Tolbiac, em torno da Biblioteca, encontra-se, em quadras com miolos abertos, habitações de alto padrão e inúmeros cinemas, restaurantes e lojas. Estes quarteirões abertos se configuram como pátios privativos pois não se misturam com o uso público.

A área de Massena terá uso predominantemente habitacional, com escolas e a renovação dos antigos moinhos existentes ${ }^{80}$. Neste bairro, a pluralidade de soluções e sua vinculação com as situações concretas é colocada pelo arquiteto Christian de Portzamparc como a grande questão do momento atual: "Após a cidade pré-industrial e a cidade industrial, as quais não podem, de modo algum, constituir um modelo teórico para o momento atual, continuamos obrigados a inventar formas da cidade contemporânea, da cidade da era das metrópoles"81.

\section{O caso de Barcelona}

Segundo Leite, em Barcelona, o processo de recuperação urbana implementado, desde a redemocratização espanhola, no início da década de 80 até o advento indutor das Olimpíadas em 92, serve como grande exemplo da implementação, com sucesso, de um plano estratégico claro, onde os diversos projetos urbanos atuaram como pólos indutores de renovação do

\footnotetext{
${ }^{80}$ BASSANI, op. cit.

${ }^{81}$ PORTZAMPARC,Christian. Revista Óculum, numero 9 agosto 97, p 41
} 
tecido urbano local. A "metástase urbana", referenciada anteriormente por Bojas,Castells e Portas, mas de fato criada por Oriol Bohigas, o diretor de Urbanismo de Barcelona naquele período.

O processo de reurbanização de Barcelona é o caso de maior sucesso em termos de projetos urbanos contemporâneos. Sucesso que vai do uso popular ao retorno financeiro, passando pela recuperação imagética da cidade ${ }^{82}$.

Segundo Bassani, em 1986, quando Barcelona foi confirmada como a sede dos Jogos Olímpicos de 1992, criou-se o "Plano Especial de Ordenação da Fachada Marítima", de responsabilidade de O. Bohigas, D. Mackay, J. Martorel e A. Puigdomenech.

A área da intervenção fica situada a leste do centro medieval, entre o Parque da Ciudadela, o bairro de habitação operária Poble Nou, e ainda, apartado da costa marítima pela presença de duas linhas ferroviárias. Esta mesma área havia sido objeto de aprovação, nos anos 60, de projeto da empresa Ribeira S/A para urbanização das praias situadas a leste do Centro Histórico, que não eram utilizadas para o lazer tampouco como paisagem.

Devido ao caráter especulativo do projeto aprovado, as associações de bairros e de arquitetos organizam um concurso paralelo chamado "Requalificação do setor de Poble Nou". A equipe vencedora, formada entre outros, por Solá-Morales e Juan Busquets, apresenta uma abordagem teórica esclarecedora, baseada em análise morfológica do processo de formação da área e das suas características específicas. O novo plano, portanto, é parte de um longo processo de entendimento das questões ali colocadas.

O "Plano Especial de Ordenação da Fachada Marítima" tinha como objetivos: criar condições de utilização das praias e dar acessibilidade ao setor leste da cidade, através da criação de habitações e novas centralidades. A partir dos significativos urbanísticos e do acervo de obras arquitetônicas de qualidade, criar desenvolvimento turístico e econômico.

A estrutura urbana proposta para a Vila Olímpica trabalha sobre a estrutura urbana existente proposta por Cerda (Plano Ensanche), que por sua vez configura a volumetria das novas quadras e estabelece o discurso de um urbanismo fixado aos contextos pré- existentes.

Este ponto articula claramente as discussões entre o planejamento moderno e o desenho urbano. Do urbanismo moderno ficam as grandes obras infra-estruturais, enquanto as soluções do desenho urbano refletem as novas condições da cidade contemporânea ${ }^{83}$. É a terceira geração de projetos urbanos articulando conceitos das duas gerações anteriores.

Segundo Benfatti, Oriol Bohigas, um dos coordenadores deste projeto, afirma que:

"A redefinição da cidade comporta efetivamente a reconsideração das formas tradiconais. Nossa geração pensou muito longamente que seria possível encontrar uma outra forma de cidade. Nós todos fomos grandes admiradores de Le Corbusier, da idéia da Cidade Radiosa, das proposições dos CIAM. Mas atualmente, estimamos que a cidade deve ter uma forma legível para aqueles que nela

\footnotetext{
${ }^{82}$ SOUZA, op. cit.

${ }^{83}$ BASSANI, op.cit.
} 
habitam. A cidade deve corresponder a uma tradição, e é por isso que julgamos que a quadra, a rua, a calçada, o jardim urbano são ainda utilizáveis e bem mais eficazes que outras formas de cidade" $" 84$.

Segundo Bassani, a reestruturação do sistema ferroviário que contou, inclusive, com eliminação de linhas, desbloqueou a cidade fisicamente em relação à frente marítima.

A inserção de um enorme verde espaço público, configurado pelo parque linear "Parc Del Mar", estrutura a faixa costeira ocupada pelo Passeio Marítimo e a faixa das habitações da Vila Olímpica ${ }^{85}$.

Situado ao longo da costa, este parque organiza e integra o sistema viário, que ora está no subsolo e depois na superfície. Preconiza-se, em Barcelona, o espaço público como grande estruturador das intervenções nas cidades renovadas.

O centro comercial do complexo, situado junto à Marina é marcado pela verticalidade das duas maiores torres da Espanha, abrigando Hotel e Serviços. A escala, de cidade contemporânea atrativa ao interesse internacional, contrasta com a implantação da Vila Olímpica que se configura pela articulação do percurso do pedestre e pela relação entre as áreas verdes projetadas e as edificações. As condições ambientais do urbano, na escala local, são valorizadas através das quadras permeáveis ${ }^{86}$.

Segundo Benfatti, nessas quadras é possível verificar influências anteriores, principalmente do IBA 87 (Internationale Bauhausstelling Berlim), uma grande área de renovação junto ao muro de Berlim. Nos dois casos observa-se um retorno à morfologia tradicional da cidade, também encontrada na proposta para a Postdamer Platz, que recompõe a rua, a quadra e a calçada $^{87}$.

Segundo Leite, constata-se a atuação de grandes nomes da arquitetura contemporânea em grandes projetos urbanos, realizados em várias cidades, buscando alternativas ao urbanismo moderno, pretendendo vencer o novo desafio da cidade sobre a cidade, através de soluções que atendam a complexidade da metrópole contemporânea.

\subsubsection{Experiências no Brasil}

No final do século $X X$, as lutas pela redemocratização de países na América Latina influenciaram a elaboração de políticas públicas, visando atender as demandas dos movimentos sociais organizados, com ênfase na participação popular nos processos de gestão e planejamento.

${ }^{84}$ BENFATTI Denio Munia. Revista Óculum, Número 9 - Ed. Agosto 1997. Publicação da Fau Puccamp p.30 Citando La Ville.Six Interventions d'architectes. Publications de Moniteur, Paris 1994 p.44.

${ }^{85}$ BASSANI, op. cit.

${ }^{86}$ BSSANI, op. cit.

${ }^{87}$ BENFATTI, op. cit., p. 44. 
O planejamento estratégico nos países Latino Americanos busca integrar as cidades ao novo panorama econômico global, desenvolvendo políticas que valorizem o potencial, a identidade e a cultura local, através da qualificação do tecido social e dos empreendimentos existentes. Procura destinar recursos para programas sociais, evitando vantagens fiscais e de infra-estrutura desmedidas para os agentes da iniciativa privada. Busca a construção de uma imagem positiva da cidade e um novo modelo de desenvolvimento.

No Brasil, pode-se citar vários instrumentos que incentivam a democratização da gestão municipal: Plano Diretor, Estatuto das Cidades, Orçamento Participativo (e suas plenárias populares), Audiências Públicas, Conferências Municipais, Conselhos Gestores e Conselhos Setoriais, Comitês de Fiscalização, Comitês Ambientais e Comissões de Co-gestão.

Segundo o Guia do Estatuto da Cidade, a idéia de introduzir operações urbanas como instrumento urbanístico no Brasil tem duas influencias: européia (principalmente francesa) e norte americana. Nesses dois casos o instrumento busca a reutilização de áreas esvaziadas e conta com o capital privado para realizar as transformações urbanísticas.

Em São Paulo, desde os anos 70, já existia a idéia de reurbanizar áreas em parceria com proprietários e investidores. Nesse contexto, reurbanizar significava realizar investimento público em áreas públicas, desapropriadas para essa finalidade, com redefinição de zoneamento. Somente em 1985 o instrumento Operações Urbanas é incluído no Plano Diretor de São Paulo, com o objetivo de atrair recursos privados visando a realização de mudanças estruturais em áreas específicas da cidade. Quatro fatores influenciaram o estabelecimento desse novo instrumento na experiência urbanística brasileira: a falta de recursos públicos, a valorização imobiliária decorrente dos investimentos públicos, o controle do potencial construtivo pelo poder público e as críticas as estratégias de uso e ocupação do solo que não captavam singularidades nem promoviam o redesenho ${ }^{88}$.

No Brasil, os projetos urbanos recentes foram, na sua maioria, implementados em diversas cidades através do instrumento de indução de desenvolvimento urbano chamado Operação Urbana, definida pelo Estatuto da Cidade (Lei 10.257/ 2001).

\section{Definição de Operação Urbana}

Segundo o Guia do Estatuto da Cidade, as operações urbanas consorciadas são um tipo especial de intervenção urbanística que visa a transformação estrutural de um setor da cidade, envolvendo o re-desenho, a combinação de investimentos privados e públicos, a alteração dos direitos de uso e edificabilidade do solo e de obrigações de urbanização. Não se restringe a questão do controle urbano, sendo um instrumento de implementação dos projetos urbanos em áreas da cidade, com a participação dos proprietários, investidores privados, poder público, moradores e usuários permanentes. As operações delimitam um setor específico da cidade, propõe utilização distinta da situação existente, visando a reconstrução e redesenho do tecido urbanístico, econômico e

\footnotetext{
${ }^{88}$ Instituto Pólis e Câmara dos Deputados. Estatuto da Cidade, Guia para implementação pelos municípios e cidadãos - Brasília 2001 -- Coordenação de publicações, p. 90.
} 
social de acordo com a política urbana definida no Plano Diretor. A Prefeitura coordena as intervenções, definidas em lei municipal, visando a preservação, recuperação ou transformação das áreas em questão ${ }^{89}$.

Conforme Maricato e Whitaker Ferreira, deve-se ter muita cautela na comparação entre as operações internacionais (francesa e norte americana) e as brasileiras, pois os instrumentos envolvem a dinamização de mercados muito mais includentes que o nosso. Esses países possuem longa tradição política, principalmente na Europa, com elevada integração dos tecidos sociais, o que possibilita o engajamento efetivo da sociedade civil nesses processos, servindo de contra peso às intenções da iniciava privada. Além disso, o poder público também possui um peso diferente do brasileiro, devido a tradição do Estado Providência Social Democrata ${ }^{90}$.

\section{O início das Operações Urbanas no Brasil}

No termos do Guia do Estatuto da Cidade, a continuidade da obra de reurbanização do Vale do Anhangabaú levantou a questão mais ampla da "revitalização" da área central e da valorização dos imóveis privados no entorno da obra gerada por este investimento. Esta foi a motivação para o estabelecimento da Operação urbana Anhangabaú (Lei 11.090/91), que tinha como objetivos a melhoria da paisagem urbana e da qualidade ambiental, o melhor aproveitamento dos imóveis vagos ou subutilizados, o incentivo à preservação do patrimônio histórico, cultural e ambiental urbano e a regularização de imóveis construídos em desconformidade com legislação urbanística e edílica vigentes. Visava, ainda, à ampliação e articulação dos espaços de uso público, em particular dos arborizados e destinados a pedestres e à complementação das obras de drenagem e infraestrutura.

Em quatro anos de vigência, apenas cinco propostas foram protocoladas, sendo que apenas a regularização de área construída da Bolsa de Valores de São Paulo foi aprovada.

Com o fim do prazo da Operação Urbana Anhangabaú, uma nova operação foi definida para a área, a chamada Operação Urbana Centro (Lei 12.349/97), agora ampliada para uma área de 660 hectares, incluindo os chamados Centro velho e Centro novo e parte de bairros centrais como Bexiga, Brás, Glicério, Vila Buarque e Santa Ifigênia.

A Operação Urbana Centro, em cinco anos de vigência, aprovou apenas uma proposta de construção nova com índices alterados (um shopping Cultural, do grupo Silvio Santos, no bairro do Bexiga) e uma regularização. Além destas, duas transferências de potencial de imóveis tombados foram realizadas.

A Operação Urbana Água Branca (Lei 11.774/95) abarca um território de 500 hectares, e sua criação justificou-se por referir-se a uma área próxima ao centro, com muitos terrenos vagos ou subutilizados e, ao mesmo tempo, bem servida por transporte coletivo nos vários modos

${ }^{89}$ Ibid., p. 90. 
- trem, ônibus e metrô - além de apresentar problemas crônicos de drenagem. A operação foi restrita, até o momento, a apenas um grande empreendimento - Centro Empresarial Água Branca - conjunto de torres comercias, das quais, quatro, estão construídas, e a obras que na verdade viabilizam o acesso e valorização do próprio empreendimento ${ }^{91}$.

Conforme Magalhães, como contrapartida foi custeada a construção do prolongamento da Avenida Auro de Moura Andrade e a restauração da "Casa das Caldeiras", patrimônio histórico tombado localizado na área"2.

Segundo Heck, conforme a conclusão da Comissão de análise do desempenho da Operação Urbana Água Branca (Portaria 132/2001), essa operação não atingiu os resultados pretendidos: na falta de um plano urbanístico, recomenda um estudo detalhado para que sejam elaboradas novas propostas e em conseqüência, que seja feita a revisão da lei ${ }^{93}$.

Conforme Magalhães, em 2003, para o local da operação Urbana Água Branca, o arquiteto Paulo Mendes da Rocha, aproveitando a oportunidade oferecida pela postulação de São Paulo à Sede dos Jogos Olímpicos 2012, conceitua um projeto que contemplava a integração total da Vila Olímpica com a área urbana da Cidade. Dentro de São Paulo "Cidade Olímpica" as instalações e Vilas Olímpicas foram agrupadas em cinco núcleos reservados durante os Jogos, distribuídos principalmente ao longo dos rios Tietê e Pinheiros e do grande lago artificial de Guarapiranga. No núcleo Água Branca foram propostas, entre outras instalações, a Vila Olímpica e o Estádio Olímpico. O projeto "São Paulo Cidade Olímpica" foi engavetado com a vitória da cidade de Londres para sediar os Jogos $^{94}$.

Em 2004, através da SEMPLA, a prefeitura de São Paulo lançou o Concurso Bairro Novo para seleção de projetos urbanísticos. Atualmente existe uma pendência jurídica entre a equipe vencedora e a prefeitura.

Conforme o Guia do Estatuto da Cidade, a Operação Urbana Faria Lima (Lei 11.732/95), envolvendo uma área com aproximadamente 450 hectares situada na região sudoeste do município de São Paulo, uma das mais dinâmicas do ponto de vista do mercado imobiliário, foi apresentada com a justificativa da necessidade de prolongamento da Av. Faria Lima, pretendendo-se

\footnotetext{
${ }^{90}$ Instituto Pólis e Câmara dos Deputados. op. cit.

91 Instituto Pólis e Câmara dos Deputados, op. cit., p. 90.

92 MAGALHAES Jr.,José. Operações Urbanas em São Paulo: crítica, plano e projeto. Parte 8 Operação urbana Água Branca, revisão e proposição. Disponível em: http://www.vitruvius.com.br/arquitextos/arq066/arq066 03.asp. Acesso em: 24 de novembro de 2007.

${ }^{93}$ HECK, Eneida R. B. Godoy. A EMURB como instrumento de planejamento Urbano em São Paulo. 1971-2001. Dissertação de mestrado FAU USP 2004 p. 192.

${ }^{94}$ MAGALHAES Jr.,op.cit.
} 
a criação de uma via paralela à Av. Marginal do Rio Pinheiros, para aliviar a saturação viária da região sudoeste ${ }^{95}$.

Segundo Sales, apesar de definir um programa de investimentos que incluem um novo terminal de ônibus, habitações de interesse social, construção de habitações multifamiliares e aquisição de imóveis para implantação de praças e equipamentos institucionais, até hoje, a Operação Urbana Faria Lima investiu apenas em melhoramentos viários, além de configurar uma nova situação fundiária com as propostas já aprovadas, já que em $60 \%$ dos casos houve agregação de pequenos lotes para formar os terrenos que se beneficiarão da Operação Urbana ${ }^{96}$.

De acordo com a Prefeitura Municipal de São Paulo, a Operação Urbana Água Espraiada (Lei 13.260/2001) estabelece diretrizes urbanísticas para a área de influência da atual Avenida Água Espraiada, de interligação entre a Avenida Nações Unidas (Marginal do Rio Pinheiros) e a Rodovia dos Imigrantes, visando a melhoria e transformações urbanísticas, sociais e ambientais na área de influência da atual Avenida Água Espraiada. O projeto tem como um dos seus principais objetivos revitalizar a região através da mescla de usos para estimular a dinâmica urbana e com a criação de espaços públicos de lazer e esportes, estabelecendo um mínimo de espaços por Setor destinados à implementação de áreas verdes.

As obras de interligação viária foram chamadas de Complexo Real Parque. A primeira fase, que foi aberta aos veículos em 2006, consistiu na entrega de dois viadutos de acesso no sentido Castelo Branco/Interlagos e Avenida Morumbi, sentido Bairro/Centro. As obras prosseguem para a construção das transposições do Rio Pinheiros sobre duas pontes estaiadas. Os recursos da Operação Urbana Águas Espraiadas, advém da venda, em leilões, de Certificados de Potencial Adicional de Construção, os Cepac's, e também de investimentos do orçamento do município $^{97}$.

Diante destas experiências, algumas críticas são publicadas.

Em 2004 Nunes aponta a necessidade de inserção das operações urbanas em um plano geral para a cidade, evitando que se tornem instrumentos arrecadatórios com baixo potencial de transformação do espaço urbano. Constata-se que as simples edições de leis não modificam ou direcionam os interesses imobiliários que está mais vinculado às demandas que à legislação. Defende a regulação por diretrizes estabelecidas na lei após a elaboração de um projeto urbanístico: "Em muitos casos, houve a inversão do processo, e tentou-se fazer com que a lei originasse um desenho da cidade, quando um desejo de cidade deve produzir uma lei que o viabilize" ${ }^{\prime 98}$.

\section{Operações Urbanas recentes}

\footnotetext{
${ }^{95}$ Instituto Pólis e Câmara dos Deputados. Estatuto da Cidade, Guia para implementação pelos municípios e cidadãos - Brasília 2001 -- Coordenação de publicações- p. 90

${ }^{96}$ SALES, Pedro M. R.. Operações Urbanas em São Paulo: crítica, plano e projetos. Parte 1 Introdução. Disponível em: http://www.vitruvius.com.br/arquitextos/arq000/esp295.asp. Acesso em: 15 de dezembro de 2007.

${ }_{97}$ Prefeitura Municipal de São Paulo.

Disponívelem:http://portal.prefeitura.sp.gov.br/empresas autarquias/emurb/operacoes urbanas/agua espraiada/0001/index html. Acesso em 11 de dezembro de 2007

${ }_{98}$ NUNES, Mônica Balestrin. A configuração espacial da várzea do Rio Tietê: a região da Água

Branca e as várzeas municipais. Dissertação de mestrado FAU USP 2004 p.174.
} 
Segundo Sales, durante o período de 2001 a 2004, dentro do Departamento de Projetos Urbanos da Secretaria Municipal de Planejamento Urbano da Prefeitura do Município de São Paulo, inicia-se um processo de reavaliação crítica das operações urbanas então vigentes na cidade. Este trabalho também elaborou as proposições para a formulação de novas operações previstas no Plano Diretor Estratégico de 2002, de modo a apontar alguns problemas da atuação urbanística na cidade contemporânea brasileira, sugerindo hipóteses de desdobramento e renovação dessa atuação.

Em 2002, a Lei Municipal $N^{\circ} 13.430 / 2002$, respaldada na Lei Federal $N^{\circ} 10.257 / 2001$ - Estatuto da Cidade - aprovou a criação de nove novas áreas de Operação Urbana Consorciada em São Paulo. Após a instituição da Operação Urbana Jacu Pêssego (2004), os esforços da administração municipal voltaram-se para a formulação de quatro operações urbanas, cada uma a seu modo, buscando responder ao processo de mudanças por que passam essas extensas e importantes partes da cidade.

As Operações Urbanas são: Operação Urbana Butantã - Vila Sônia, Operação Urbana Vila Maria - Campo de Marte, Operação Urbana Vila Leopoldina - Jaguaré e Operação Urbana Diagonal Sul ${ }^{99}$.

Segundo Sales com o objetivo de avançar estratégias de atualização, qualificação e integração da base territorial, técnica e social da cidade de São Paulo e obter maior alcance urbanístico e social, as novas operações urbanas procuram:

i) fugir da armadilha arrecadatória, da lógica tributarista e/ou especulativa que muitas vezes acabam se sobrepondo às decisões e interesses públicos;

ii) garantir a recuperação e distribuição da mais-valia gerada pelo próprio investimento público, e, assim, regular distorções de valorização geradas por esses mesmos investimentos;

iii) promover formas de ocupação mais intensa, qualificada e inclusiva do espaço urbano articuladas a medidas que racionalizem e democratizem a utilização das redes de infra-estrutura e equipamentos sociais ${ }^{100}$.

Conforme Sales, a Operação Urbana Butantã-Vila Sônia tem como principal característica a exploração das possibilidades urbanísticas provenientes da implantação da nova

\footnotetext{
${ }^{99}$ SALES, Pedro M. R.. Operações Urbanas em São Paulo: crítica, plano e projetos. Parte 1 Introdução. Disponível em http://www.vitruvius.com.br/arquitextos/arq000/esp295.asp. Acesso em: 15 de dezembro de 2007.

100 SALES,Pedro M. R.. Operações Urbanas em São Paulo: crítica, plano e projetos. Parte 3 Operações Urbanas: plano-referência e proposições. Disponível em: http://www.vitruvius.com.br/arquitextos/arq000/esp310.asp Acesso em: 18 de dezembro de 2007.
} 
linha do metrô (Linha 4), que interconectará a Vila Sônia à Luz, no Centro da cidade ${ }^{101}$.Segundo Sales, a Operação Urbana Diagonal Sul, com área de 2.000 ha requalifica os terrenos ao longo do vale do Tamanduateí, nos bairros do Pari, Brás, Mooca, Ipiranga e Vila Prudente, basicamente composto por áreas de origem ferroviária ou industrial ${ }^{102}$.

Conforme Bernardini, a Operação Urbana Vila Leopoldina-Jaguaré, possui área de 1028 ha na região da Lapa, ocupada por antigas indústrias e próxima ao CEAGESP apresenta potencialidades para, frente ao abandono das atividades industriais, se requalificar junto ao desenvolvimento do vetor oeste de expansão da cidade e do processo de verticalização da Vila Leopoldina $^{103}$.

Segundo Oliveira, a Operação Urbana Carandiru - Vila Maria, com área de 1752 ha, tem como objetivo absorver parte da valorização do entorno da Casa de Detenção, gerada pela sua desativação e implosão, entre os anos de 2002 e 2005. Outro fator importante é a proximidade do centro da cidade e a infra-estrutura instalada. Com o objetivo de, foi criada a Operação Urbana ${ }^{104}$.

\section{Exemplos de Operações Urbanas no Brasil}

De acordo com o Guia do Estatuto da Cidade, ao contrário das grandes áreas definidas nas propostas de São Paulo, pelo Brasil, são mais comuns as chamadas pequenas operações urbanas, entre as quais destacamos as seguintes:

Em Natal/RN, desde 1997, as operações urbanas estão localizadas em áreas passíveis de adensamento mas que apresentam valor histórico-cultural significativo para o patrimônio da cidade. Os bairros de Cidade Alta e Ribeira são áreas de operação urbana em andamento, apesar de poucos resultados e de falta da participação popular.

Em Belo Horizonte/MG, o instrumento "Operação Urbana" consta do Plano Diretor de 1996. É uma parceira entre o poder público municipal, proprietários e a Rede Ferroviária. Consiste na requalificação de área degradada da Rede Ferroviária que possui uma edificação tombada - Casa do Conde de Santa Marina. O terreno e a edificação passarão a ser propriedade pública, para abrigar o Museu do Trem em um contexto de uso cultural para todo o terreno. A contrapartida será a cessão de parâmetro urbanístico adicional para o terreno remanescente, que permanece patrimônio da Rede Ferroviária.

\footnotetext{
${ }^{101}$ SALES, Pedro M. R. Operações Urbanas em São Paulo: crítica, plano e projetos. Parte 4 Operação Urbana Butantã - Vila Sônia. Disponível em: http://www.vitruvius.com.br/arquitextos/arq000/esp311.asp. Acesso em 18 de dezembro de 2007. ${ }_{102}$ SALES, Pedro M. R.. Operações Urbanas em São Paulo: crítica, plano e projetos. Parte 5Operação Urbana Diagonal Sul. Disponível em: http://www.vitruvius.com.br/arquitextos/arq000/esp315.asp. Acesso em: 18 de dezembro de 2007 ${ }^{103}$ BERNARDINI, Marcelo M.. Operações Urbanas em São Paulo: crítica, plano e projetos. Parte 6 - Operação Urbana Vila Leopoldina Jaguaré. Disponível em: http://www.vitruvius.com.br/arquitextos/arq062/arq062 03.asp. Acesso em: 10 de dezembro de 2007. ${ }^{104}$ OLIVEIRA, José G. M. de. Operações Urbanas em São Paulo: crítica, plano e projeto. Parte 7 - Operação Urbana Carandiru - Vila Maria". Disponível em: http://www.vitruvius.com.br/arquitextos/arq065/arq065 03.asp. Acesso em: 03 de setembro de 2007.
} 
Em Campo Grande/MS consta no Plano Diretor de 1991, com a nomenclatura "Urbanização Negociada" e "Urbanização Consorciada" em 1995.

Foi criada especificamente para o projeto Urbanização do Parque das Nações Indígenas. Envolve a criação de um parque, ao longo de futuras novas avenidas em área central. O proprietário cedeu a área à municipalidade em troca de potencial construtivo em outras áreas. Como a lei não foi mais utilizada, em 2000, a Prefeitura a reformula, definindo áreas de novas operações urbanas, principalmente de enfoque cultural e ambiental, como o Centro, Antiga Estação de Trem e cabeceiras de córregos ocupadas ilegalmente. Admite, para tais locais de interesse do município, a transferência de potencial, alteração de índices e usos desde que vinculando à realização de obras de interesse social ou de requalificação urbanística.

Em Mauá/SP, consta no Plano Diretor de 1998, onde diversas operações urbanas estão previstas, e cada uma delas tem uma lei específica. Merecem destaque duas das operações realizadas:

A primeira, na área abandonada da rodoviária, próxima à Prefeitura, onde uma parte da área foi comprada pelo McDonald's, que construiu um teatro e duas escolas municipais.

A segunda área, ao longo da Avenida dos Estados, tinha como antigo uso: um estacionamento, uma fábrica e uma rua pública. Toda a grande área foi desafetada para dar lugar a um Shopping, que em contrapartida assumiu um termo de compromisso de construir um "Centro de Educação para o Menor".

Em Santo André/SP, ocorre a combinação de um grande projeto com pequenas operações urbanas.

O Projeto Eixo Tamanduatehy, lançado pela prefeitura em 1998, propõe-se a requalificar o principal eixo de transportes da cidade, correspondendo a uma faixa de $12,8 \mathrm{~km}^{2}$ situada entre a Avenida dos Estados, a estrada de ferro e a Avenida Industrial. Em um primeiro momento, foram elaboradas propostas para o projeto de requalificação da área, sem que no entanto se chegasse a um projeto que sintetizasse e integrasse o conjunto das propostas. Dessa maneira, o Eixo Tamanduatehy não configurou um projeto de lei de Operação Urbana. Mesmo na ausência do projeto síntese, foram realizadas pequenas operações urbanas, referentes a empreendimentos isolados e implementadas por meio de leis específicas para cada projeto.

Operação Urbana Industrial I - 1997

Permuta de área para abertura de via, com contrapartida em doação de área, visando a ampliação do sistema viário da Av. industrial.

Operação Urbana Industrial II / Cyrella - 1998/99

Concessão de benefícios urbanísticos através de outorga onerosa e da doação de 16.545,60 $\mathrm{m}^{2}$ de área com a contrapartida visando a ampliação e reforma (obras e equipamentos) do Parque Duque de Caxias.

Operação Urbana Flat da Av. Portugal - 1998

Concessão de benefícios urbanísticos caracterizados pela permissão da categoria de uso no lote, em área de $3.000 \mathrm{~m}^{2}$ com a contrapartida visando o custeio da execução do projeto arquitetônico do "Centro de Atividades Andrezinho Cidadão". 
Operação Urbana Cidade Pirelli - 1998

Plano urbanístico de revitalização de área de $187.300 \mathrm{~m}^{2}$ com a concessão e benefícios urbanísticos e mudança de zoneamento através de outorga onerosa, permuta de áreas e de isenção de IPTU. No local serão construídos um Hotel 4 estrelas, Centro de Convenção, praças e Rua de Comércio 24 horas. O destino da contrapartida foi o custeio da execução do projeto arquitetônico do "Centro de Atividades Andrezinho Cidadão"105.

\section{Operações Urbanas em Campinas}

Em Campinas, o instrumento "Operação Urbana" consta no Plano Diretor de 1996 e são dois os exemplos. Um caso, em fase de elaboração, é a chamada Operação Urbana Consorciada CIATEC e o outro exemplo é a já implementada Operação Urbana Consorciada Parque Linear do Rio Capivari - Trecho Cerâmicas, de 21 de outubro de 2004.

A Operação Urbana Parque Linear Cerâmicas - Capivari, situada ao longo do Rio Capivari, na região sudoeste de Campinas, entre as rodovias Santos Dumont e a dos Bandeirantes, propõe a criação de um Parque Urbano.

A área apresenta, ao longo das últimas décadas, por sua situação estratégica e peculiar no território regional, expressivo crescimento urbano e populacional. Abriga, em sua área de influência, cerca de 300.000 habitantes e se mostra desprovida de infra-estrutura básica, equipamentos sociais e com recreação e lazer em extrema dependência para com a área central do Município. A premissa básica é: "A implantação de um extenso e multifuncional parque urbano em um território explorado à exaustão, beneficiando diretamente um terço da população campineira constituir-se-á em um elemento propulsor de requalificação sócio-espacial da cidade e região."

São objetivos da Operação Urbana: compatibilizar a proteção aos recursos naturais e da paisagem com o atendimento das necessidades sócio-espaciais da região, além de promover a requalificação das áreas degradadas e áreas de interesse sócio-ambiental, através da implementação e criação de áreas verdes, de recreação e lazer.

Entre outros aspectos, busca recuperar as áreas degradadas pela extração de argila e areia; promover melhoramentos nas áreas de habitações sub-normais com o estabelecimento de programas de reurbanização e regularização fundiária e criar estímulos para a implantação da mescla de usos, de índices e parâmetros urbanísticos, compatíveis com as tendências e potencialidades da localização das glebas e lotes.

O Parque proposto estrutura-se em quatro setores articulados de espaços públicos e áreas verdes, visando: a recomposição da mata ciliar, a integração da Mata Santa Terezinha constituição de um bosque urbano e a criação de um passeio público ligando a Mata Santa Terezinha ao corpo do Parque Linear. Além de atividades como Lazer Ativo, Lazer Contemplativo, Preservação Ambiental

\footnotetext{
${ }^{105}$ Instituto Pólis e Câmara dos Deputados., op. cit., p. 90.
} 
e cultura, além das atividades esportivas e institucionais, o Parque prevê portais de serviços públicos, espaços para exposições e eventos e ciclovias. ${ }^{106}$

Apesar de instituída desde 2004, a Operação Urbana não obteve êxito junto à iniciativa privada.

A outra Operação Urbana, em fase de elaboração, é a Operação Urbana Consorciada CIATEC, para viabilizar o Parque Tecnológico de Campinas, a ser construído no Pólo II de Alta Tecnologia do município. O projeto faz parte do Sistema Paulista de Parques Tecnológicos que o governo estadual quer implantar. Serão quatro parques: Campinas, Região Metropolitana de São Paulo, São José dos Campos e em São Carlos.

Em área de quase 8 milhões de metros quadrados, entre as rodovias Dom Pedro I e Campinas-Mogi Mirim, tem como fronteira a Unicamp e a PucCampinas. Nesta área já estão instaladas mais de 30 empreendimentos. São empresas, Incubadoras, Institutos de Pesquisa e de Ensino, tais como Xtal Fibras Ópticas, Benchmark, Magneti Marelli Divisão Eletrônica, Pósitron e Northern Telecom, que geram 3 mil empregos. Na mesma gleba encontram-se o Laboratório Nacional de Luz Síncrotron (LNLS), o Centro de Pesquisa e Desenvolvimento em Telecomunicações (CPqD) e o Softex Campinas.

A proposta é que o parque científico e tecnológico se volte para a atração de pequenas empresas de base tecnológica em área onde hoje se encontra o Pólo Ciatec II, constituído na década de 1970.

O estudo prevê melhores ligações viárias do Parque com a Unicamp, a PUC-Campinas e as rodovias Dom Pedro I e Campinas-Mogi, sendo que edificações de interesse histórico e os elementos da paisagem ambiental serão integrados a um plano de uso misto que prevê: novas empresas, residências, setor de hotelaria, convenções, esporte, lazer e entretenimento ${ }^{107}$.

Com base nesta realidade local, inserida no contexto global descrito, pretendo contribuir por um estudo das questões urbanas contemporâneas no território de Campinas, visando o debate e o desenvolvimento de idéias e diretrizes a serem consolidadas na forma do Projeto Urbano Anhumas.

\footnotetext{
${ }^{106}$ CAMPINAS, Prefeitura Municipal. Disponível em: http://www.campinas.sp.gov.br/seplama/projetos/pqcapivari/portparqcapivari.htm. Acesso em: Março de 2007

107 Boletim INOVAÇÂO UNICAMP.

http://www.inovacao.unicamp.br/report/news-parque.shtml Publicada em 14 de julho 2005
} 


\section{CAPÍTULO 2 - CAMPINAS}

$\mathrm{Na}$ primeira parte desse capítulo, pretendo descrever um breve histórico sobre o desenvolvimento urbano de Campinas, desde o surgimento do pouso em 1722 até a cidade contemporânea. Para isso, utilizarei como base o livro "O despontar da Modernidade"108 de Ricardo Badaró e "O Plano de Requalificação Urbana da Área Central de Campinas"109 da Secretaria de Planejamento, Desenvolvimento Urbano e Meio Ambiente.

Na segunda parte estabeleço uma leitura em escala metropolitana que aborda os aspectos legais ambientais e de tecido urbano pertinentes à área de estudo.

\subsection{Campinas: histórico}

\section{A fundação}

Segundo Badaró, Campinas nasce em 1722 em um local destinado ao pouso de bandeirantes à beira do caminho dos Guaiases, que ligava São Paulo às novas jazidas de ouro em Goiás e Mato Grosso. Os três campinhos com regatos ofereciam água e alimentação para as tropas, além da oportunidade de descanso em meio a densa mata que cobria a região.

Esses fatores favoreceram a construção de um pouso e o desenvolvimento de um bairro rural pertencente e dependente da Vila de Jundiaí, chamado Bairro do Mato Grosso das Campinas. Em 1745, o bairro era formado por pequenas propriedades rurais, com aproximadamente 200 pessoas, onde se desenvolviam atividades básicas de subsistência através da policultura rudimentar com destaque para o milho e os eventuais excedentes eram trocados à beira da estrada por sal e utensílios.

As dificuldades decorrentes da distância de Jundiaí favorecem o surgimento do cemitério em 1753 e da licença para a construção da Igreja Matriz de

\footnotetext{
108 BADARÓ, Ricardo de Souza Campos. - Campinas, o despontar da modernidade. Unicamp, 1996, Campinas.

109 CAMPINAS, Prefeitura Municipal. Plano de Requalificação Urbana da Área Central de Campinas", 2002.
} 
grande porte em 1773. Em 1774, uma capela provisória é construída e determina a praça ao redor da qual o núcleo urbano da Freguesia de Nossa Senhora da Conceição se desenvolve. Esse momento marca a fundação do povoado e o fundador Barreto Leme segue orientações do Governador para o dimensionamento das quadras e ruas, num traçado retilínio e ortogonal.

O núcleo inicial, localizado nas proximidades do atual viaduto Laurão, entra em declínio com a alteração da estrada para os lados da igreja e passa a ser chamado Bairro das Campinas Velha.

A área urbana cresceria ao norte para o Bairro Santa Cruz e ao sul para os lados do Cemitério e em 1796 atingiria uma área de aproximadamente 26 mil metros quadrados.

\section{A Vila da Cana de Açúcar}

Em 1797 a Freguesia é elevada à condição de Vila, sendo chamada de Vila de São Carlos, ocorrendo a delimitação do território, demarcação do rossio e localização da Casa do Conselho e Cadeia, além da construção do Pelourinho, na praça central.

A elevação dos preços do açúcar no mercado internacional no final do século XVIII, transformou a economia e os hábitos locais com a agro-indústria do açúcar, voltada para a exportação, tornando-se a atividade principal da Vila.

Esse desenvolvimento é impulsionado pelas mudanças decorrentes da vinda de D. João VI para o Brasil, em 1808 e da independência em 1822.

Surgem grandes latifúndios para o cultivo da cana, instalam-se engenhos para a produção do açúcar e há a necessidade de um grande número de escravos para a produção. Aparecem os primeiros traços de riqueza, com os casarões e sobrados dos senhores de engenho da elite nascente, sendo construídos com taipa de pilão, substituindo as casas térreas de pau a pique. Nesse período surgem novos arruamentos e construções como a Catedral (1807-1833), Teatro São Carlos (1814), Igreja do Rosário (1817) e Casa do Conselho e Cadeia (1825-1830).

O Comércio dependia das tropas de burro que levavam o açúcar para Santos e voltavam com produtos importados e também estendeu-se pelas ruas centrais. A agro-indústria do açúcar influencia a organização espacial e funcional da 
Vila, que basicamente tinha papel administrativo e religioso complementar à vida dos mais de 100 engenhos existentes, até princípios da década de 1840.

Entre 1800 e 1830, o uso do café se generaliza na Europa. A partir de 1830 o Brasil se torna o maior produtor mundial principalmente com a produção para exportação no Vale do Ribeira. O esgotamento das terras nessa região fez com que a cultura cafeeira migrasse para o interior paulista.

A partir de 1835, o café se torna significativo para a economia da Vila, impulsionada pelos preços internacionais, pela fertilidade das terras, além da menor mão de obra requerida para a sua cultura. A produção do açúcar foi prejudicada pelas geadas de 1840,1841 e 1842 e é superada pela do café.

\section{A Cidade do Café}

Em 1842 a Vila de São Carlos é elevada à condição de cidade, sendo denominada Campinas. A vila do açúcar vai se transformando na cidade do café, que adquire grande prestígio político e social no país pelo crescimento e riqueza. A partir de 1850 o cenário se modifica com o aumento dos custos internos decorrentes da distância cada vez maior das fazendas até o porto de Santos devido ao deslocamento das lavouras e com o fim do tráfico negreiro que elevou o custo da mão de obra. Quando os preços internacionais eram favoráveis havia a expansão da lavoura e esse aumento da produção quando chegava ao mercado provocava a queda dos preços levando a uma situação de impasse no final da década de 1860. Em 1868 houve uma quebra na produção mundial que elevou os preços provocando uma nova fase de expansão da produção no Brasil.

Em relação à questão da mão de obra a solução encontrada pelos fazendeiros foi a introdução da máquina de beneficiamento do café, o que melhorou a qualidade do produto e do preço internacional.

A implantação de estradas de ferro, a partir de 1865, foi a solução para as dificuldades do transporte da produção. Em 1867 é inaugurada a São Paulo Railways ligando Jundiaí a Santos. Em 1877 é inaugurada a Central do Brasil no Rio de Janeiro. Em 1872 os trilhos da Companhia Paulista de Vias Férreas e Fluviais ligam Campinas à Jundiaí, possibilitando a ligação com São Paulo e Santos além dos trilhos Campinas - Limeira - Rio Claro. Em 1875 surge a Companhia Mogiana de Estradas de Ferro ligando Campinas e Mogi Mirim. Em 1889 é inaugurada a 
Companhia Ramal Férreo Campineiro, ligando a região produtora de Sousas e Joaquim Egídio com o centro da cidade e em 1899 a Estrada de Ferro Funilense liga Campinas e Cosmópolis.

Nesse cenário, Campinas assume a função de Pólo Regional, sendo a maior produtora nacional de café, mas a questão da mão de obra se colocava uma vez que o movimento abolicionista ganhava força e a cidade era a que possuía o maior número de escravos em São Paulo.

Com a substituição da mão de obra escrava pelo trabalhador assalariado, negro ou imigrante, ocorre a modificação dos procedimentos de distribuição de terras no Brasil a partir de 1854. Não haveria mais doação a quem as cultivasse e sim a venda, o que dificultava a posse dos imigrantes ou negros libertos que ficavam sem alternativa a não ser trabalhar nas lavouras alheias.

Campinas recebe imigrantes Alemães, Belgas, Suíços e Tiroleses a partir da década de 1850. Nos anos 1860 chegam os franceses e a partir dos anos 1870 os italianos. Em 1873 a população era de 33.000 habitantes, sendo 13 mil brancos e 20 mil negros. A vida cultural era intensa com o surgimento de colégios e associações artísticas, literárias e musicais. Muitos estudantes se formavam na Europa ou nos Estados Unidos e a cidade tornou-se um dos centros mais importantes da articulação e propaganda dos ideais republicanos nos anos que antecederam a proclamação da República. Crescia o centro comercial estimulado pelas estradas de ferro que atraiam consumidores do interior e da capital além de possibilitar transações diretas com os europeus.

A partir de 1875 iniciam-se obras de infraestrutura, possibilitando água encanada e tratada, telégrafo, serviço postal, iluminação a gás e sistema de bondes de burro.

A economia cafeeira serve de base para o desenvolvimento industrial, através da criação de demandas e da concentração de capital que era investido quando os preços do café não estavam bons. Com a imigração italiana, a mão de obra cria condições para o crescimento industrial e com a valorização dos terrenos centrais as indústrias e trabalhadores buscavam a periferia, ao longo das saídas da cidade.

Em 1888, Campinas tinha cerca de 20 mil habitantes na área urbana e 50 mil na área rural. Surgem as questões relacionadas ao saneamento já que não 
havia água encanada nem esgoto, com as ruas terminando em brejos e córregos que envolviam a cidade.

Ocorre a distinção precisa de classes sociais e gera consequentemente as diferenciações arquitetônicas.

Com isso, se dá a substituição da Taipa de Pilão por Tijolo, principalmente devido às obras necessárias ao beneficiamento de café.

As Estações e Armazéns passaram a ser o vetor de desenvolvimento da área urbanizada, demarcando novos limites para a cidade.

Campinas estava envolvida com Questões Sanitárias desde 1850, pois o lixo tinha condição precária, com esgoto em praças e cemitérios insalubres. Importante lembrar que a Abolição da Escravatura contribuiu para aumentar população urbana.

As primeiras ações da Câmara (Poder Público) em 1889 foram: eliminação de cocheiras da área central, fornecimento de água tratada (1891) pela Cia. Campineira de Águas e Esgotos e implantação do primeiro "Código de Construção" da cidade, em 1895.

Três surtos consecutivos de febre amarela, a partir de 1889, interrompem a fase de prosperidade. A epidemia provocou inúmeras mortes e um forte êxodo entre 1889 e 1897, provocando a redução da população para 5 mil habitantes. A intendência municipal toma medidas para o combate a epidemia, com a retomada das obras de infra-estrutura da Cia. Campineira de Águas e Esgotos para o abastecimento predial de água e para destinação dos esgotos sanitários. Em 1896 implanta-se o primeiro Código de Construção da cidade com dimensões para recuos, áreas de iluminação e ventilação, cômodos e janelas, altura de pavimentos e pisos além da espessura de paredes e revestimentos.

\section{A Cidade Industrial}

O Engenheiro Saturnino de Brito, com investimentos realizados pelo governo estadual, implementa planos para abastecimento, tratamento e distribuição de água para toda a cidade, melhorias na coleta e destinação do lixo e esgotos além da canalização de córregos e drenagem de charcos. Dessa forma, mesmo sem a finalização das obras, houve a modificação do aspecto da cidade e o controle da epidemia. 
Em 1900, Campinas tem 19 mil habitantes, população equivalente a que possuía antes da epidemia, ganha em organização, infra-estrutura e saneamento, mas economicamente perde a primazia do desenvolvimento industrial para a Capital. Os anos após a epidemia não foram favoráveis para a comercialização do café, o que não contribuiu para a instalação de muitas fábricas em Campinas, no início do século XX. O Município passa a investir em obras de pavimentação, abertura das avenidas Anchieta e Canal de Saneamento, atual avenida Orozimbo Maia, canalização do córrego Tanquinho e melhoria no abastecimento de água para os novos bairros.

Campinas ostentava exemplares condições de vida urbana e estava preparada para retomar o crescimento econômico baseado nas culturas do café e do algodão e no processo de industrialização. A cultura algodoeira se associa à indústria têxtil e muitas indústrias se instalam produzindo máquinas para agricultura, fios, tecidos, roupas, couros, peles, produtos químicos e laticínios que atendiam ao mercado das novas zonas cafeeiras de São Paulo e Paraná. Essa diversificação industrial é decorrente de vários fatores: Paralização das importações em decorrência da Primeira Guerra Mundial, proximidade com a capital, entroncamento ferroviário, energia elétrica desde 1905, além das boas condições de infra-estrutura e de vida urbana em Campinas.

Em 1920 a população da cidade atinge 50 mil habitantes e ocorre um grande crescimento da área urbana a partir de 1925. Surgem novos bairros que extrapolavam os limites do rossio, como resultado da divisão das chácaras e fazendas de café mais próximas, com patrocínio da iniciativa privada individual ou de companhias de loteamento, que surgiram devido a grande procura pelos terrenos escassos na cidade após 1922. Dessa forma a especulação imobiliária entra em ação, influenciando o novo desenho da cidade.

A Prefeitura não tinha meios nem diretrizes para controlar e orientar o crescimento da cidade decorrente dos novos loteamentos privados que muitas vezes não obedeciam critérios técnicos nem a um planejamento geral, causando problemas nas ligações viárias, abastecimento de água e esgotos. Essa expansão indiscrimidada, maior que a demanda da população colocou a prefeitura em uma situação desconfortável.

Surgia a necessidade da elaboração de um plano que devolvesse o controle da Prefeitura sobre a malha urbana. A lembrança das consequências da 
epidemia de febre amarela, somente controlada após grandes investimentos no saneamento, também contribuiu para a idéia da necessidade de um plano de urbanismo para Campinas.

Em 1929, o prefeito Orozimbo Maia se posiciona de maneira favorável a necessidade da elaboração de um planejamento urbano para o futuro da cidade, com a elaboração de uma planta cadastral constando todos os novos loteamentos que serviria de base para o empreendimento. A Revolução de 30 atrasa essa realização e o processo começa novamente somente em 1933 com propostas do engenheiro Carlos Stevenson.

Somente em 1934 institui-se o Código de Construções que regulamentava os arruamentos e construções e alturas dos edifícios, especificava usos e ocupações próprias para cada uma das quatro zonas em que a cidade foi dividida. Nesse ano foi contratado o engenheiro arquiteto Francisco Prestes Maia para estudar um plano de urbanismo para a cidade.

\section{O Plano de Melhoramentos Urbanos}

O Plano de Melhoramentos Urbanos proposto por Prestes Maia e aprovado em 1938, tem forte influencia dos princípios gerais contidos na Carta de Atenas, tanto pela metodologia como no conteúdo.

Muitas propostas se perderam nas discussões prévias da implementação do plano, mas a idéia de modernidade está presente na intenção de adequar a ordenação espacial às necessidades da cidade industrial. Grandes avenidas, praças, parques, edifícios públicos e privados, bairros residenciais, distritos industriais e um novo sistema viário devem compor uma linguagem urbana nova, que romperia com o passado. O plano previa a noção de planejamento contínuo, com controle e correções da implantação através de revisões periódicas. Na prática o plano foi reduzido e aceito pelas comissões de urbanismo e houve uma continuidade técnica e administrativa que garantiu a implantação das obras planejadas ao longo de três décadas.

Observa-se dois momentos de condução do plano: Entre 1938 e 1948 com o predomínio de critérios técnicos e orientação dos engenheiros municipais. De 1949 a 1962, a condução passa a ser mais política, deformando-se pelo clientelismo ou submetendo-se aos interesses privados. 
Nas décadas de 1950 e 60 os casarões do século XIX cedem lugar aos edifícios de escritórios e apartamentos, renovando a região central. (PRUACC)

Essa importante experiência de urbanismo acaba em 1962 com forte influencia da recessão econômica. Após 1964 os recursos financeiros e as decisões se concentraram na esfera federal, dentro do novo quadro político e institucional imposto pelo regime autoritário. Os municípios deveriam fazer planos diretores para conseguir os financiamentos federais. Reduz-se a participação da população local nas decisões sobre a sua cidade.

Em 1971 foi aprovado o Plano de Transportes que propunha um sistema de vias expressas radiais, acoplado a um anel viário, com o automóvel como meio prioritário. A região central apresentava trânsito congestionado e dificuldades crescentes de acessibilidade mas somente as vias Aquidabã e Suleste foram parcialmente executadas. Inicia-se o processo de migração do comércio e os pequenos serviços para as regiões residenciais próximas, configurando a região chamada de centro expandido.

A partir da década de 1970 a expansão urbana observada foi marcada pela crescente horizontalização e periferização dos espaços urbanizados, com a formação de vazios urbanos retidos como reserva de valor, o que determinou, em grande média, a intensificação do processo de articulação urbana de Campinas com os municípios limítrofes e a conformação de áreas conturbadas.

O padrão de instalação industrial do processo de interiorização do desenvolvimento, privilegiando grandes eixos rodoviários regionais consolidou-se principalmente no vetor sudoeste de expansão da cidade (ver imagens 19 e 20), configurando áreas situadas além da Rodovia Anhanguera, em direção aos municípios de Sumaré , Hortolândia, Monte-Mor e Indaiatuba. Contribuíram muito para essa consolidação a implantação do Aeroporto de Viracopos, pela implantação do Distrito Industrial e construção de vários conjuntos habitacionais através das Cohabs Campinas e Bandeirantes.

A crise do petróleo e a recessão econômica, fazem minguar os recursos para intervenções no espaço urbano.

Em 1983 desenvolve-se um plano para a implantação de uma Rede Básica de Transportes que priorizava o ônibus e valorizava o pedestre, através da otimização do sistema viário existente. 
Esse plano também foi somente parcialmente implantado, demonstrando as dificuldades de implementação, o imediatismo administrativo e a falta de um projeto urbano socialmente validado capaz de dar a ação municipal o sentido de continuidade.

A partir dos anos 80, investimentos privados de grande porte passam a se concentrar em empreendimentos na região da Rodovia D. Pedro I, em busca de amplas áreas com melhores condições de acesso e preços, evitando a área central valorizada e congestionada.

O processo de metropolização em curso exigia essa nova escala para facilitar o fluxo local e regional de automóveis e modernizar os padrões de segurança e conforto. A saída do comércio e serviços mais sofisticados, faz com que a região central entre em um processo de popularização, com o crescimento da economia informal e a instalação e fixação do comércio de ambulantes.

Desde a década de 80, apesar do crescimento da cidade e da região, 0 centro de Campinas enfrenta um processo de degradação. A cidade inchou, viu a população empobrecer e os problemas sociais se agravarem. A precariedade das habitações e as deficiências do sistema de transporte são os problemas que mais atingem a população de baixa renda.

Em 1996 foi implantado o Projeto Rótula visando reorganizar a circulação viária e restringir o acesso de veículos à área central. As avenidas perimetrais internas e externas voltam a operar como anéis de contorno ao centro e ao centro expandido. No final dos anos 90, com a competição do transporte alternativo e informal, ocorre a desorganização do sistema de transporte coletivo. Posteriormente ocorre a regularização do transporte por peruas de forma complementar ao transporte coletivo.

\section{A Região Metropolitana de Campinas}

No ano 2000, foi criada a Região Metropolitana de Campinas, constituída por 19 cidades, com população de aproximadamente 3 milhões de habitantes.

Atualmente Campinas é pólo dessa importante região econômica do país, com grande participação no produto interno bruto nacional, contando com um 
parque industrial moderno e diversificado, com a presença de muitas empresas multinacionais, com estrutura agrícola e agro-indústria significativa. É um diversificado centro comercial e possui vários Institutos de pesquisa e universidades.

Além da malha viária integrada, possui o aeroporto de Viracopos. Com o projeto de ampliação que duplicará sua área e ampliará a capacidade de passageiros/ano, o aeroporto de Viracopos se tornará o maior aeroporto de carga da América Latina e terá intenso fluxo de passageiros, desafogando o Aeroporto Internacional de Cumbica.

Ainda segundo o projeto, a conexão entre o aeroporto e o centro se dará através de trem de superfície, reativando o leito sul da malha ferroviária. O ponto de conexão central será a rodoviária intermodal, em fase de execução, a ser instalada no vazio urbano da Fepasa.

\subsubsection{Análise da configuração da morfologia da área de estudo}

Neste momento apresento através de imagens o desenvolvimento urbano da cidade de Campinas, com destaque à área de estudo.

O objetivo principal é evidenciar a importância dos leitos ferroviários na história da cidade de a conseqüências de sua desativação. Este leitos passam, de antigos limites do perímetro da malha da cidade, para vazios urbanos fragmentadores do tecido urbano da cidade contemporânea. 


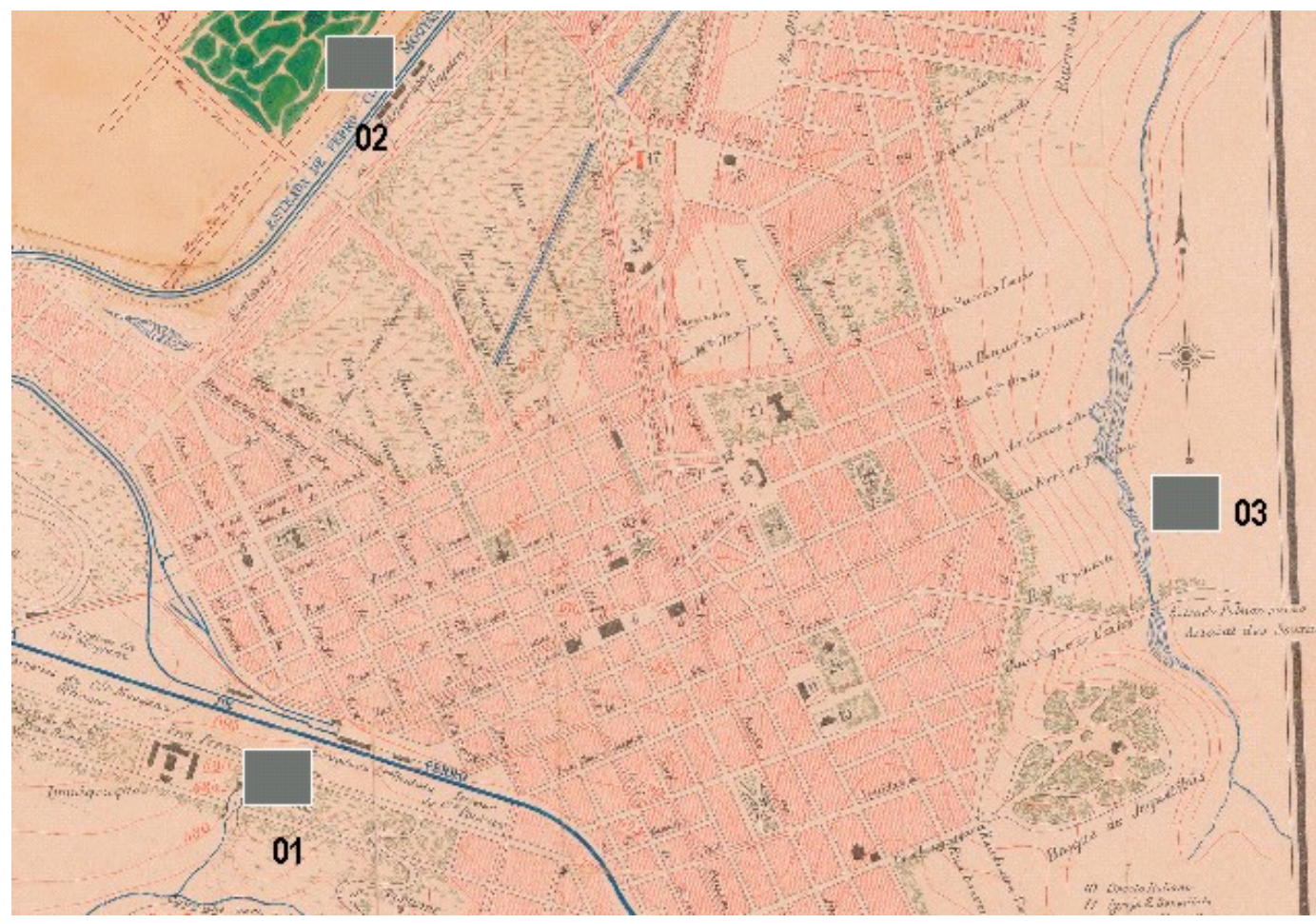

Imagem 01 Mapa de 1900 - Ampliação da mancha urbana central indicando o local dos novos limites urbanos: 01-Pátio da Fepasa (ao sul), 02- Pátio Guanabara (à oeste) e 03- As margens do córrego Proença (ao leste).

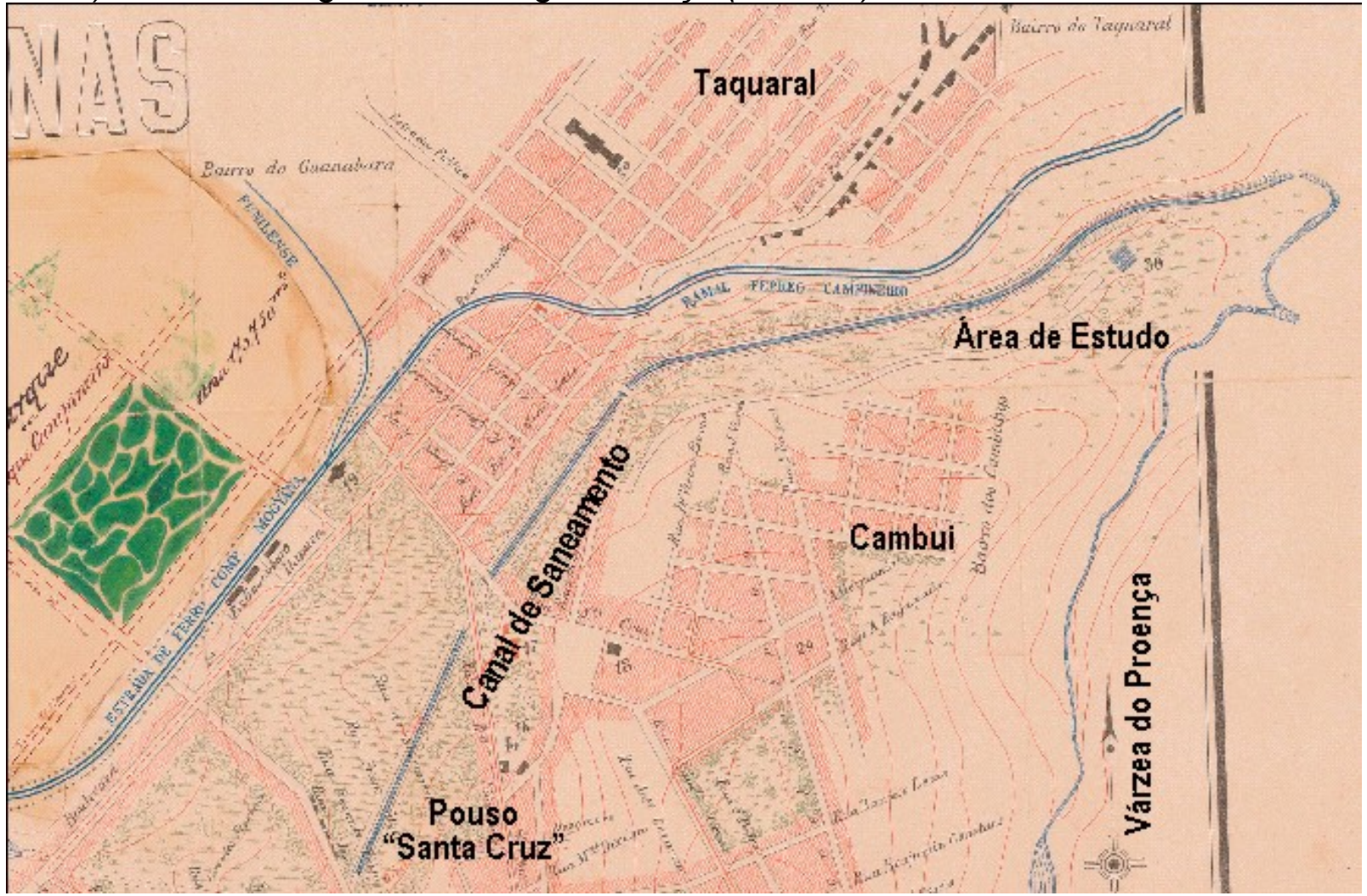

Imagem 02 Mapa de 1900 - Ampliação da mancha urbana indicando o local da Área de Estudo configurada pelas margens do Proença (à leste), pelo Canal de Saneamento e o bairro Cambuí (à suleste ) e pelo Bairro do Taquaral (à noroeste). A área rural definia o quadrante nordeste. 


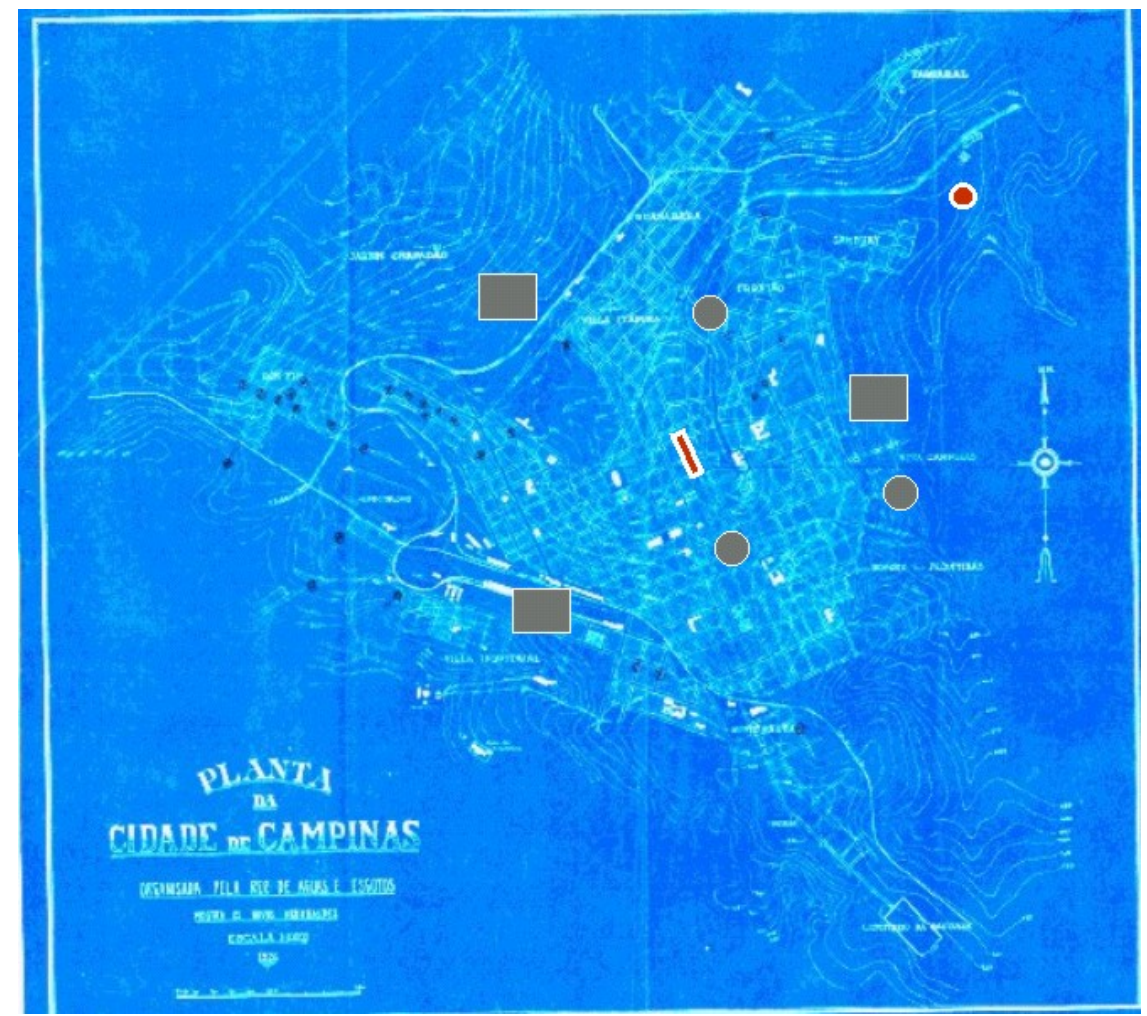

Imagem 03: Mapa de 1926 -Mancha Urbana com sinalização dos antigos Pousos (círculos), a Praça de Câmara e cadeia (retângulo vermelho), os antigos Limites Urbanos (retângulos cinza) e o círculo vermelho para demarcar a Área de Estudo.

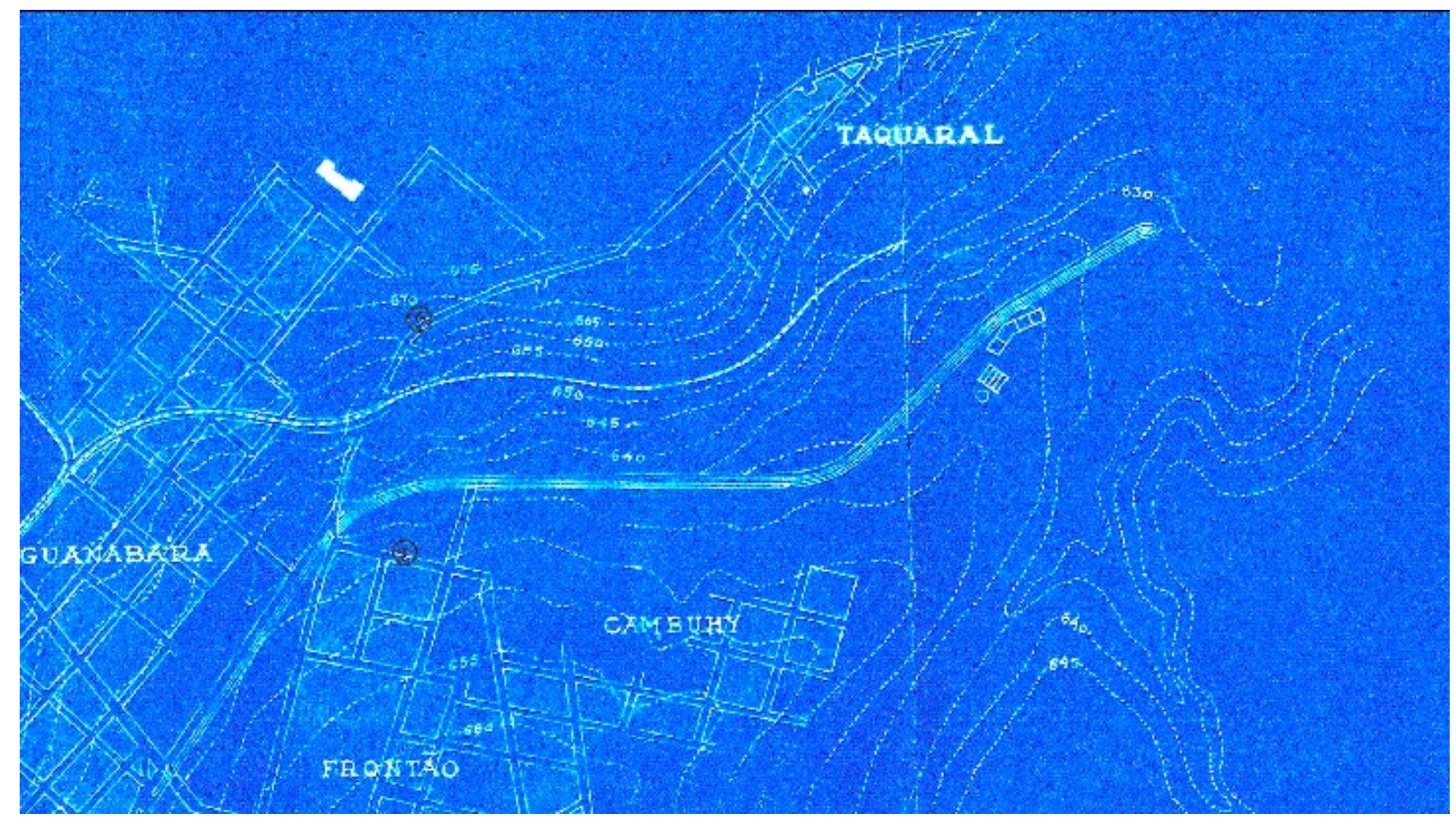

Imagem 4: Mapa de 1926 - Ampliação da mancha da área de Estudo, já com equipamentos de Tratamento de Esgoto. 


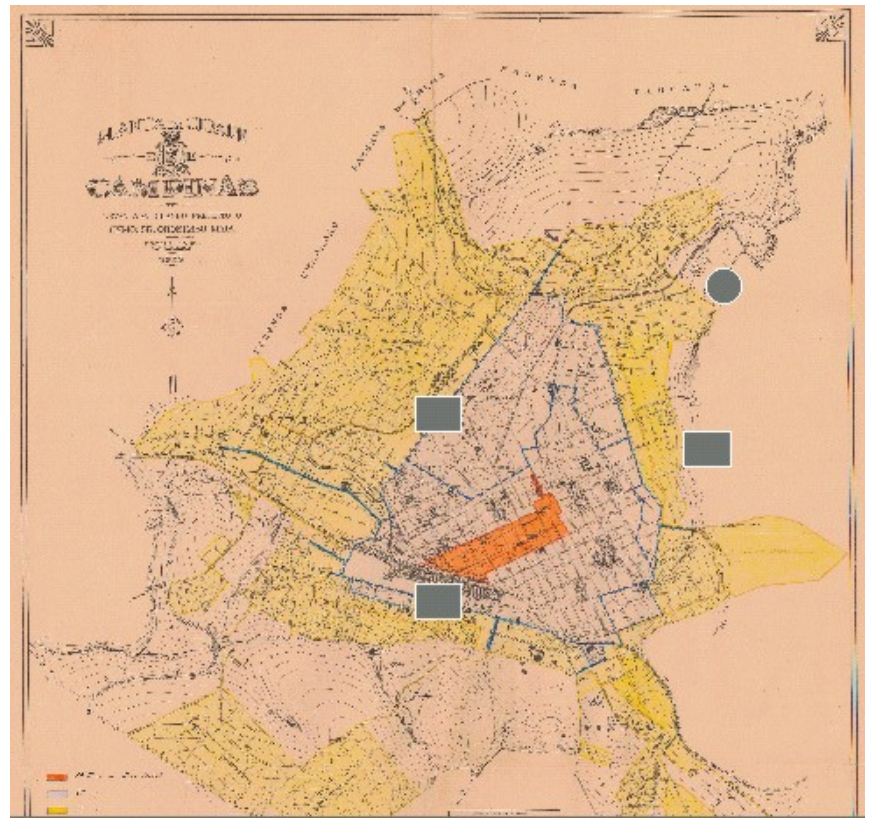

Imagem 5: Mapa de 1929 -Mancha Urbana com sinalização do Centro Histórico (mancha laranja), os antigos Limites Urbanos (retângulos cinza) e o círculo cinza para demarcar a Área de Estudo.

Observar que a mancha urbana já ultrapassa o limite sul do Pátio da Fepasa (com a Vila Industrial já configurada), ultrapassa o limite oeste do Pátio Guanabara (com o bairro Guanabara já configurado) e as margens do Proença ainda se mantém como limite da zona urbana (à leste).

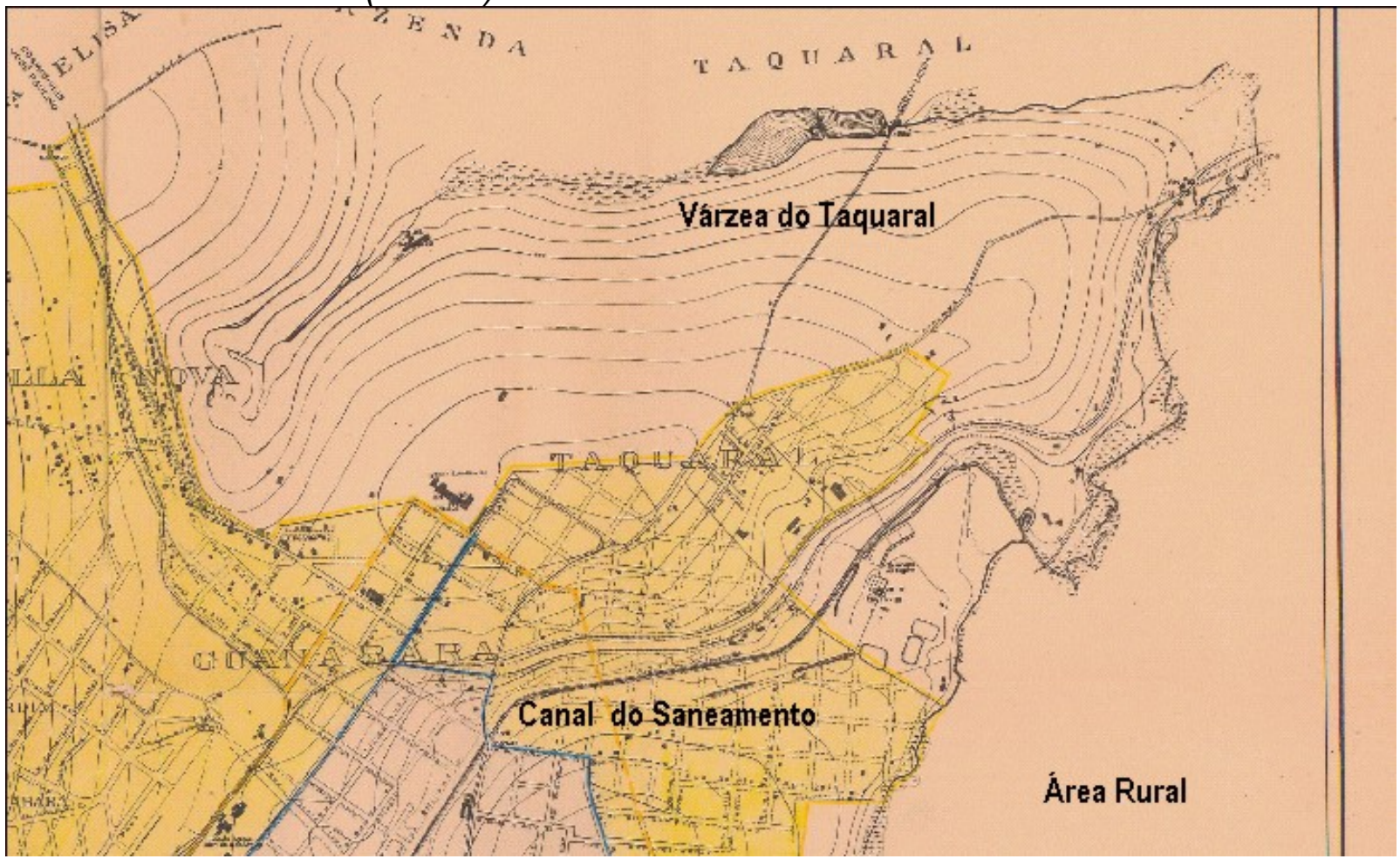

Imagem 6: Mapa de 1929 - Ampliação da Área de Estudo configurada pelo Bairro Cambuí (à sudeste), Margens do Proença e Área Rural (à leste) e Bairro Taquaral e sua várzea (à noroeste), o Leito Ferroviário da Mogiana e Leito do Ramal Férreo correndo paralelos (à oeste), alem das áreas de várzea do Canal de Saneamento e do Proença. 


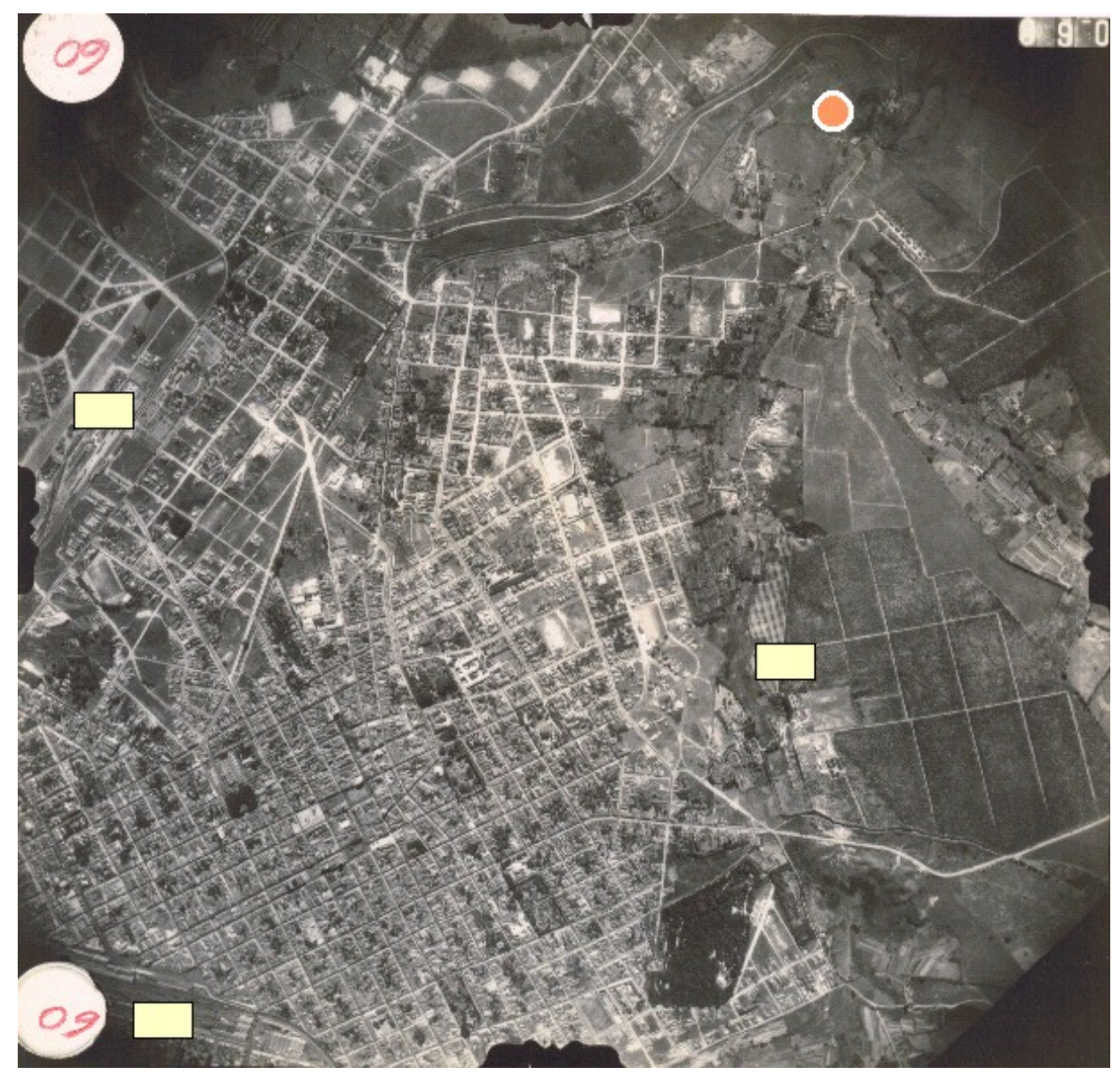

Imagem 7: Imagem Aérea de 1940 - Mancha Urbana de Campinas com indicação em amarelo dos antigos Limites Urbanos, sendo: O limite sul do Pátio da Fepasa, o Limite Oeste do Pátio Guanabara e as margens do Proença ainda se mantêm como Limite Leste da zona urbana. Em laranja, a Área de Estudo.

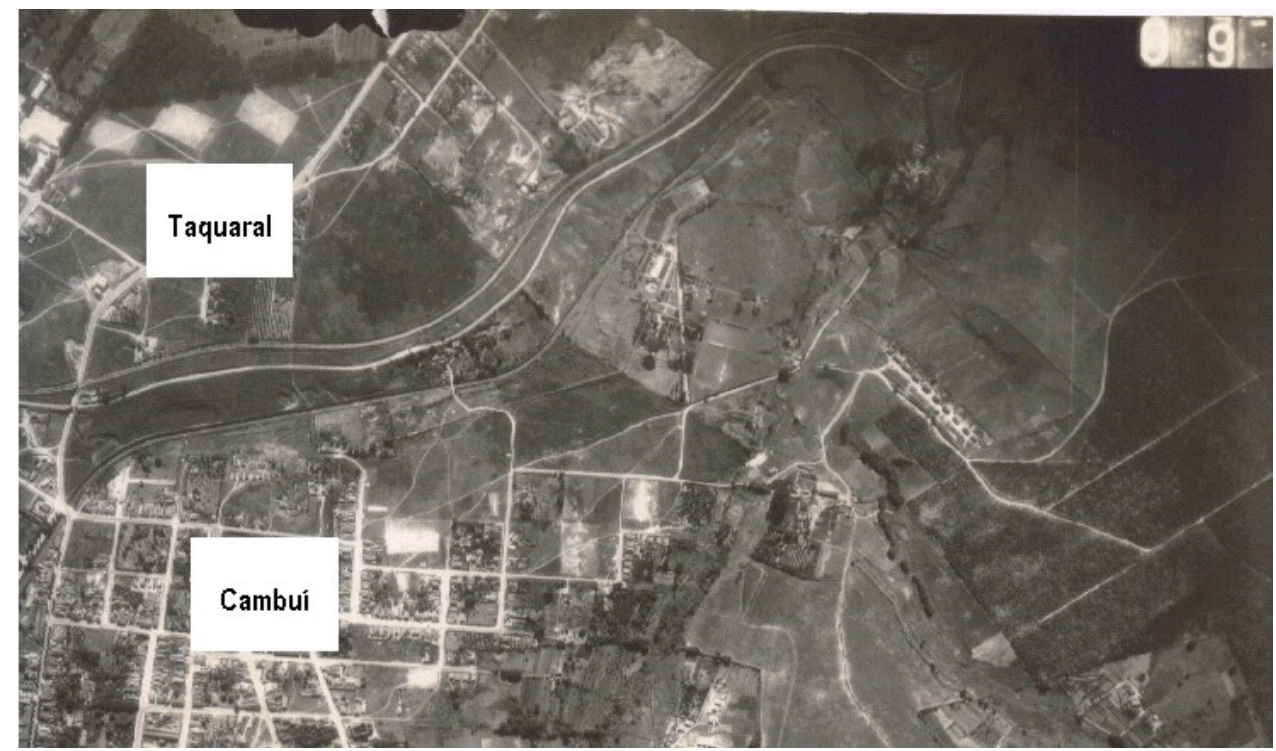

Imagem 8: Imagem Aérea de 1940 - Mancha Urbana de Campinas com ampliação da Área de Estudo. 


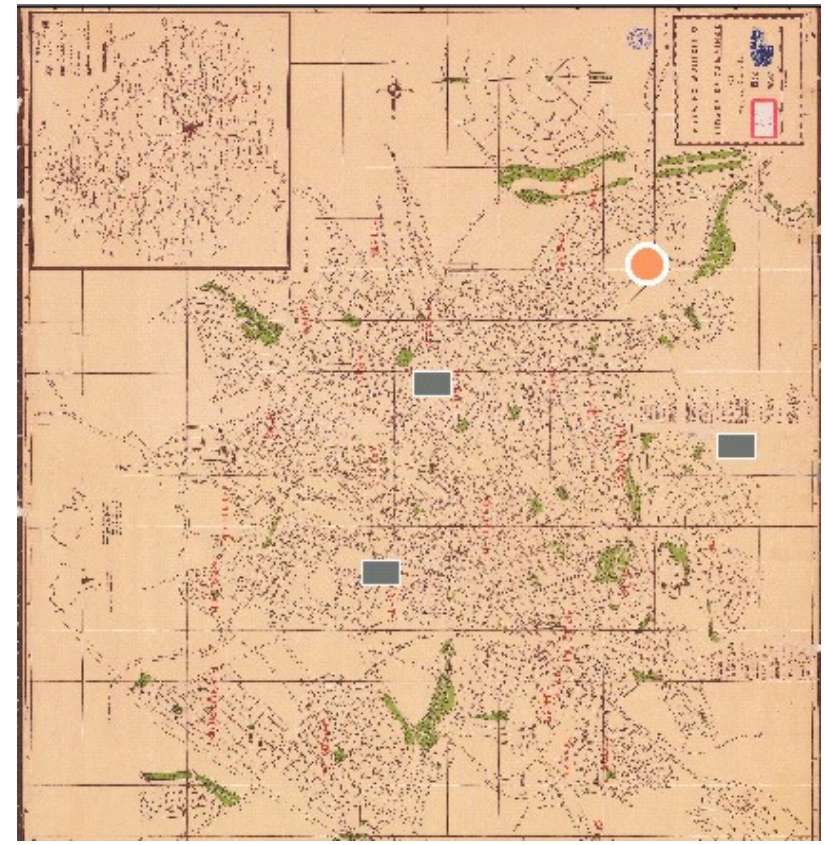

Imagem 9: Mapa de 1952 - Mancha Urbana e indicação dos antigos Limites Urbanos (retângulos cinza) e a Área de Estudo em laranja.

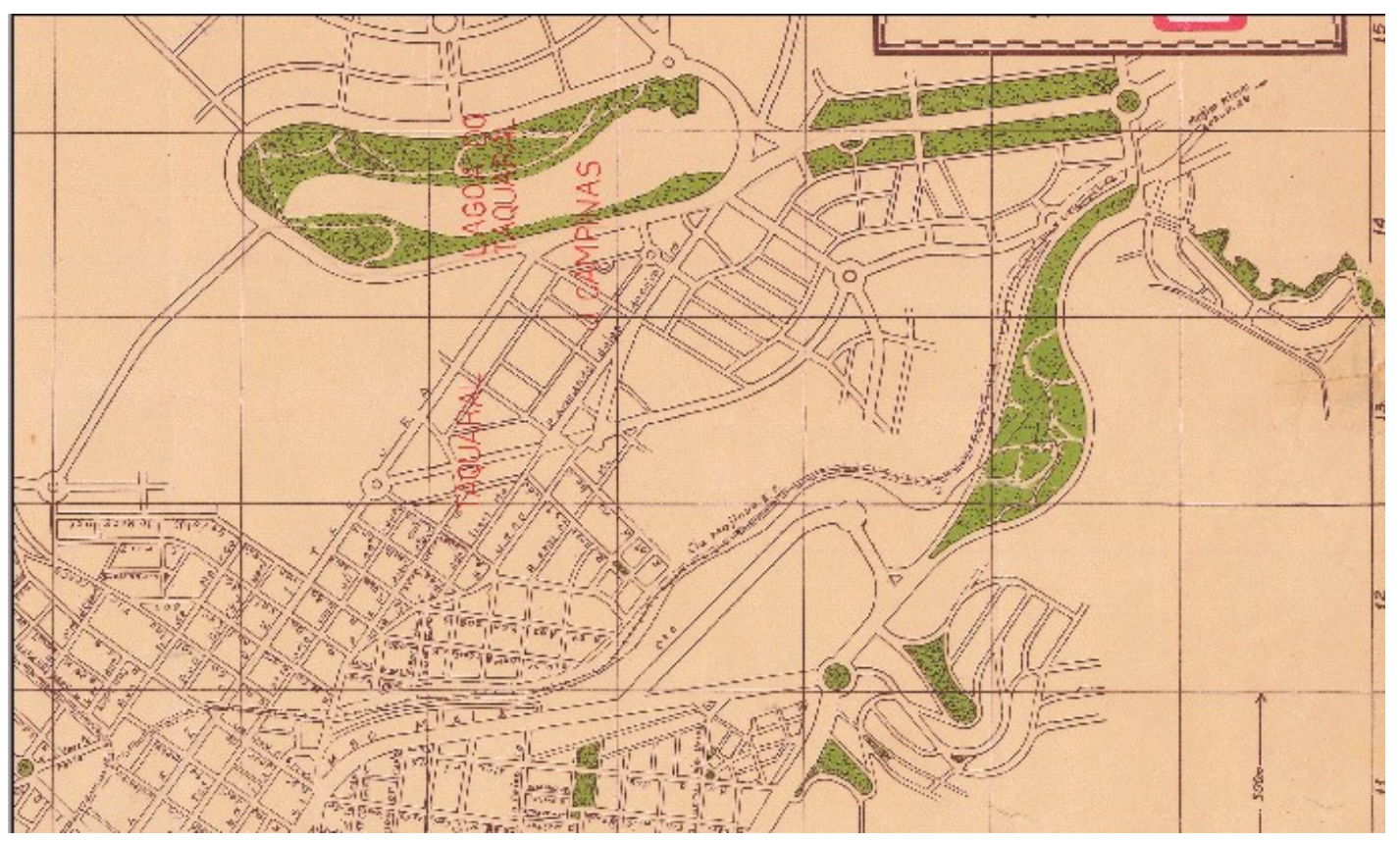

Imagem 10: Mapa de 1952 - Ampliação da mancha urbana da Área de Estudo.

É importante perceber a área já configurada por ocupação urbana à leste, à sudeste o bairro do Cambuí, à oeste o bairro do Taquaral bem consolidado e a noroeste estudo de ocupação da Lagoa do Taquaral, já com intenção de conexão com a Área de Estudo através de Área Verde. 


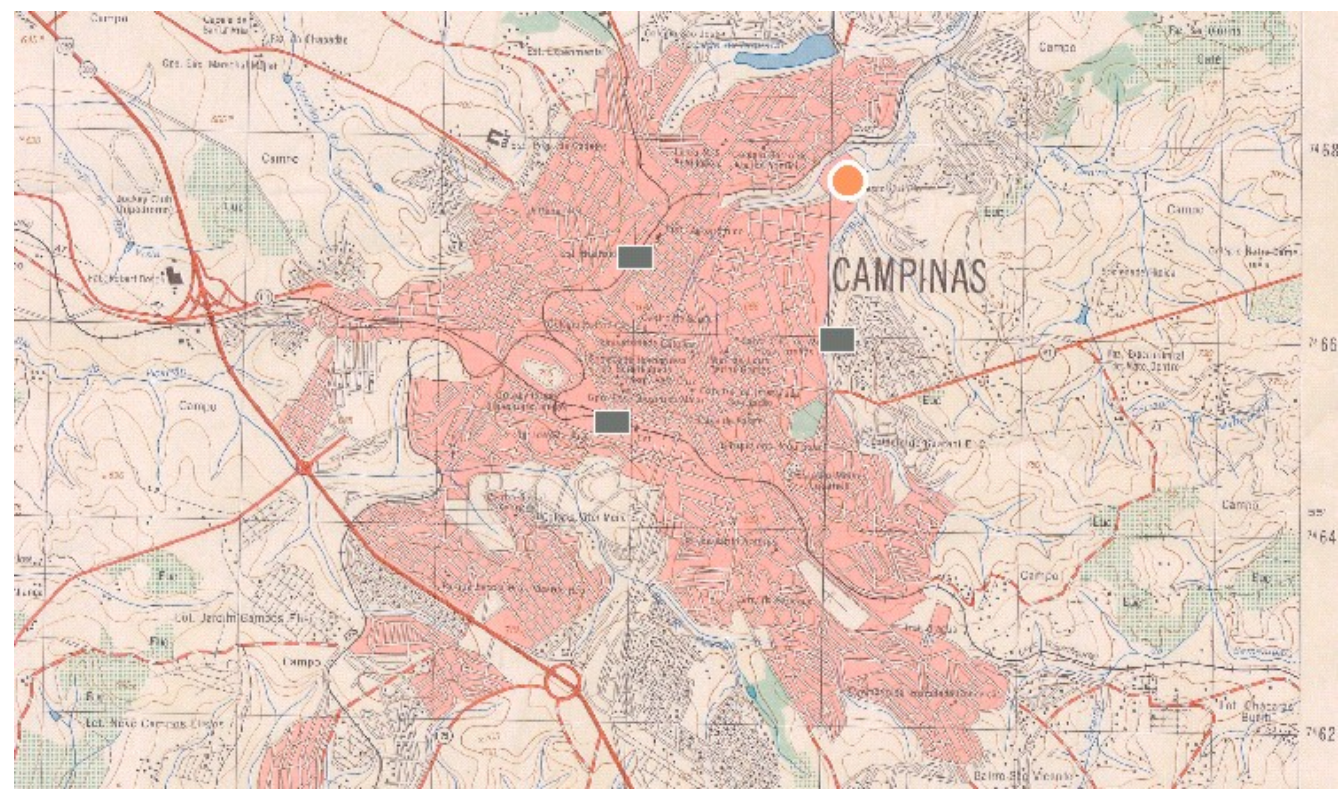

Imagem 11: Mapa de 1974 - Mancha Urbana indicando os antigos Limites Urbanos (retângulos cinza) e a Área de estudo em laranja. Notar as rodovias cruzando o tecido urbano e o início da Urbanização Dispersa.

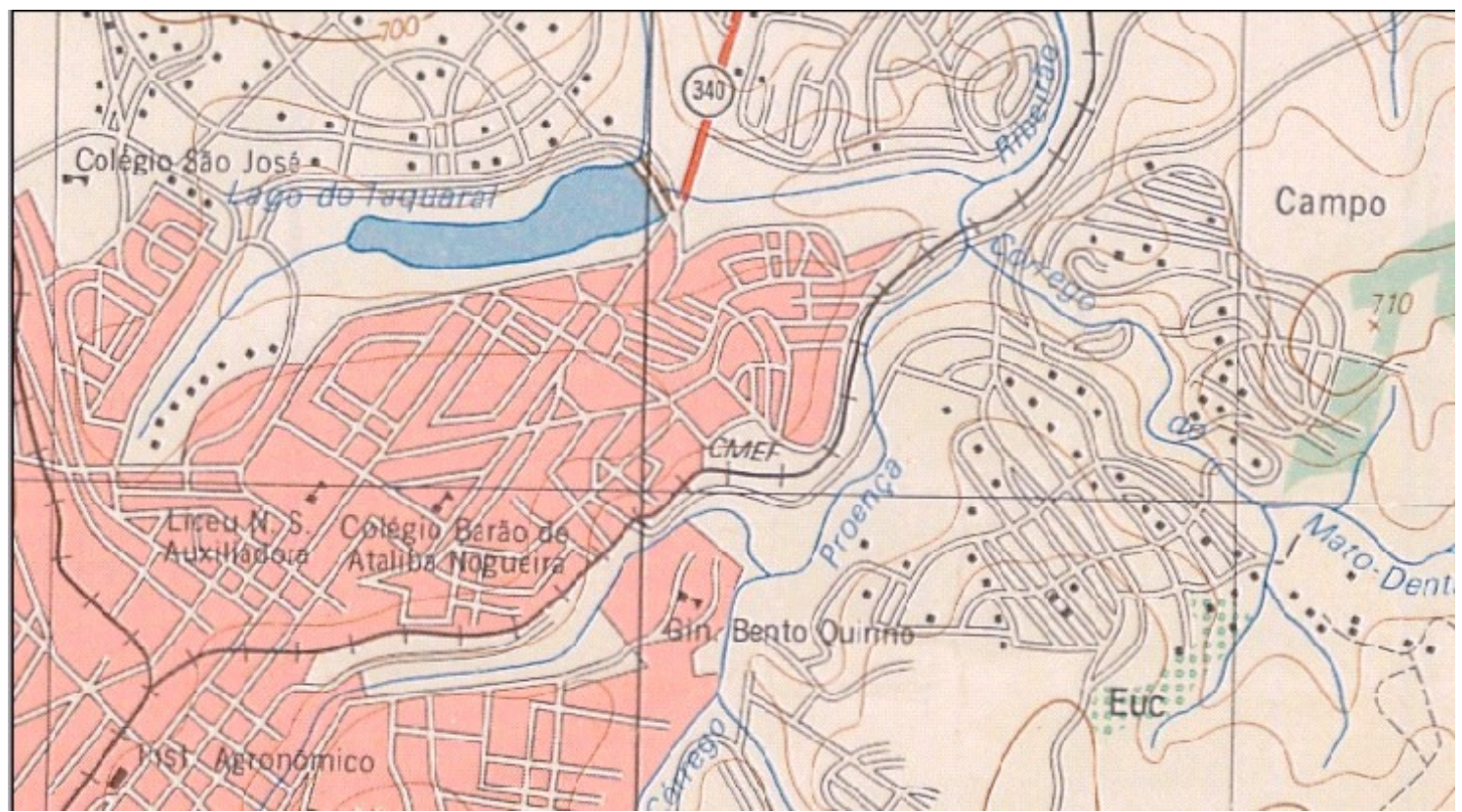

Imagem 12: Mapa de 1974 - Ampliação da Área de Estudo, completamente envolvida pelo tecido urbano. 


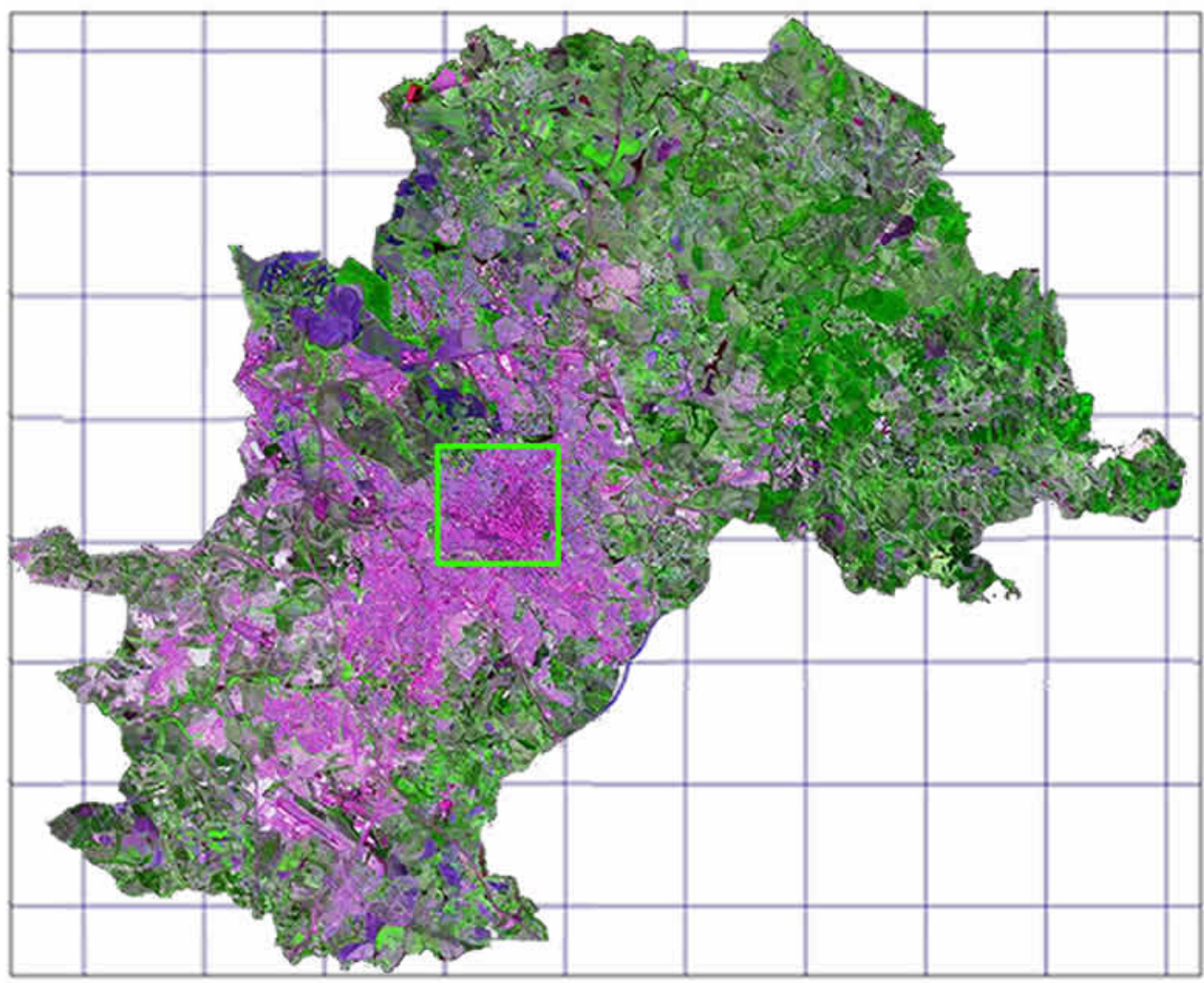

Imagem 12A: Município de Campinas - Imagem de Satélite e indicação da área de estudo - Fonte: Embrapa

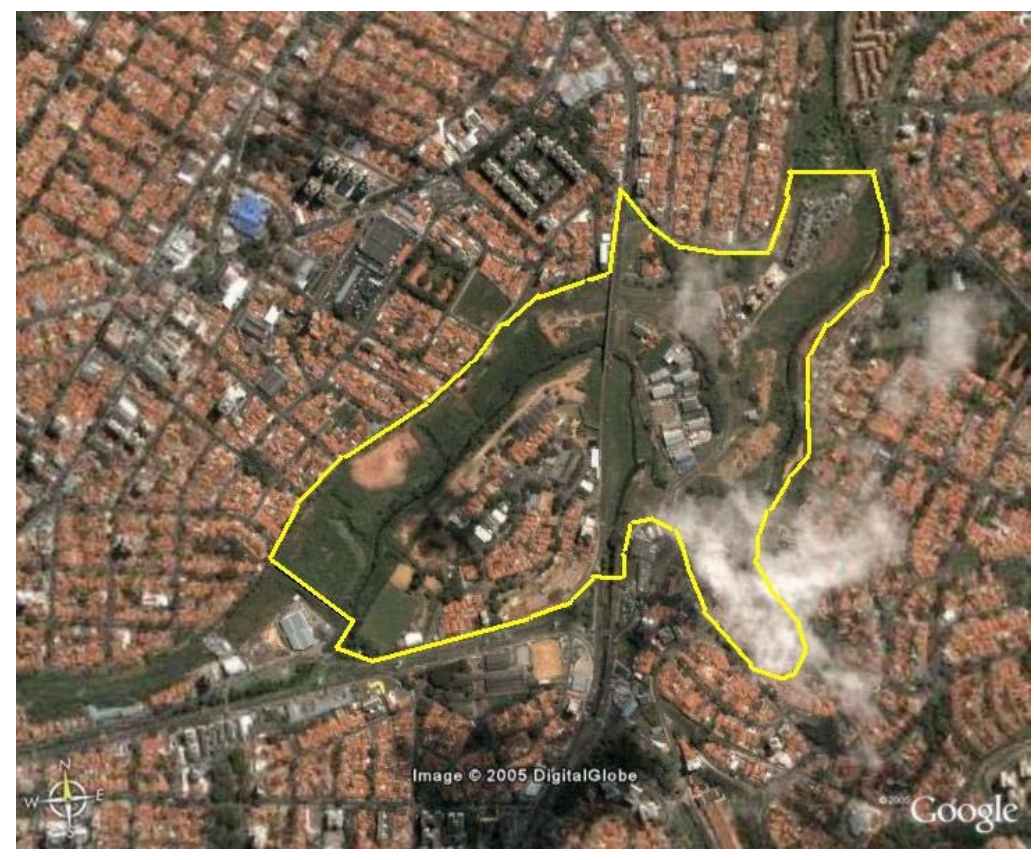

Imagem 12B: Perímetro da área de estudo editado pelo autor sobre imagem de Satélite ( Google Earth) 


\subsection{Campinas Contemporânea: leitura na escala metropolitana}

\subsubsection{Questão Legal}

O município de Campinas está dividido em sete Macrozonas, para fins de planejamento administrativo. Destas Macrozonas, a de número 4 é uma área de urbanização consolidada e adensada, abrangendo toda a região central da cidade, e concentrando o maior número de atividades urbanas do município. De acordo com o Senso Demográfico de 1991 (Prefeitura Municipal de Campinas, 1995) a população desta Macrozona era de cerca de 600 mil pessoas, ou quase $70 \%$ da população do município, dos quais $7 \%$ eram de favelados, o que representava $61 \%$ da população favelada de Campinas. A região é cortada por córregos e ribeirões que drenam para as duas bacias hidrográficas que atravessam o município, as bacias dos rios Atibaia e Capivari.

Citando o Plano Diretor de Campinas de 2006:

É objetivo do macrozoneamento de planejamento, a partir da compreensão das diferentes realidades das regiões do município, orientar o planejamento e a definição de políticas públicas, especialmente aquelas definidoras e/ou indutoras do processo de urbanização. Para tanto, foram estabelecidas diretrizes estratégicas para as diferentes macrozonas.

Para a definição das macrozonas partiu-se dos estudos básicos de caracterização e da análise da problemática urbana de Campinas, considerando, especialmente:

- a questão ambiental: identificam-se as áreas com restrições à ocupação urbana, quais sejam, as com potencial de exploração agrícola e mineral e as de preservação e proteção do patrimônio ambiental (cultural e natural): explicitam-se as delimitações e as condições das bacias hidrográficas.

- a estrutura urbana: análise do perfil de parcelamento, uso e ocupação das diferentes regiões e das tendências de crescimento urbano e dinâmicas de transformação presentes; estudo da capacidade de infra-estrutura instalada e prevista, notadamente quanto ao sistema viário, transportes, drenagem, água e esgotamento sanitário. 
Como limites das macrozonas ( ver imagem 01) foram utilizados principalmente os divisores de água das microbacias e as barreiras físicas existentes no município. Foram identificadas macrozonas de planejamento com o seguinte perfil:

- Macrozona 1 - Área de Proteção Ambiental - APA;

- Macrozona 2 - Área com Restrição à Urbanização - ARU;

- Macrozona 3 - Área de Urbanização Controlada Norte - AUC-N;

- Macrozona 4 - Área de Urbanização Consolidada - ACON;

- Macrozona 5 - Área de Recuperação Urbana - AREC;

- Macrozona 6 - Área de Urbanização Controlada Sul - AUC-S;

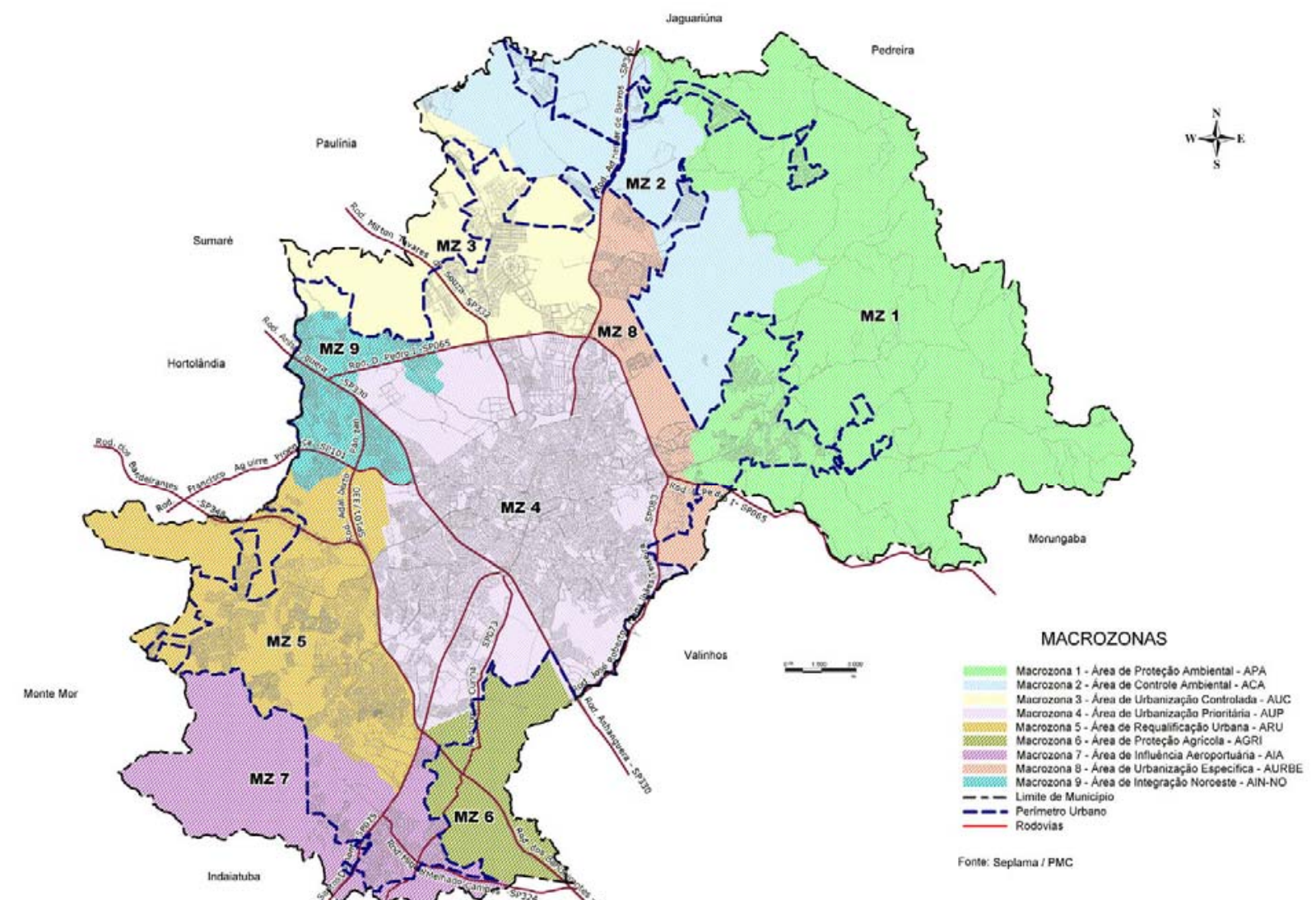


Da proposta de estruturação urbana de Campinas explicitada no macrozoneamento de planejamento destaco as seguintes orientações estratégicas:

- recuperação das áreas precariamente urbanizadas, com requalificação e estruturação urbana, buscando a articulação dos bairros existentes e criação de subcentros, com fomento à mescla criteriosa de atividades e geração de empregos, objetivando a reversão da condição de periferia! dormitório ou de espaço desaparelhado, sem, contudo, incentivar um adensamento contínuo da região

- manutenção e preservação de áreas verdes, de áreas de proteção dos mananciais e de áreas com vocação rural e de pesquisa científica, tais como as fazendas Santa Elisa e Chapadão e as bacias do Samambaia, Atibaia e Jaguari, visando ao equilíbrio ambiental;

- permissão da expansão do centro, com intensificação de atividades e adensamento da ocupação do entorno (Castelo, Guanabara, Taquaral), com controle adequado;

- abertura de novas possibilidades de adensamento e de localização de atividades geradoras de emprego em locais potencializados pelos investimentos públicos, notadamente em viário e transportes;

- estruturação do sistema viário e de transportes, considerando também as intervenções previstas (Veículo Leve sobre Trilhos - VLT, Trem Intrametropolitano - TIM, novo terminal rodoviário intermunicipal, complementação do anel viário), de maneira a diminuir os fluxos de passagem pelo centro.

\subsubsection{Questão Ambiental}

Quanto aos impactos ao Meio Ambiente, analisaremos brevemente a bacia do ribeirão Anhumas e a situação dos fragmentos das Áreas Verdes originais, bem como o alinhamento com a criação dos Eixos Verdes em processo de implantação. 


\section{Bacia do ribeirão Anhumas Localização}

A bacia do ribeirão Anhumas corresponde a uma superfície de $15.024,82 \mathrm{ha}$, aproximadamente $150 \mathrm{~km} 2$. Tem sua maior parte inserida no município de Campinas e uma pequena parte no município de Paulínia, a noroeste da bacia, onde o ribeirão desemboca no Rio Atibaia.

Situa-se em uma área de transição entre o Planalto Atlântico e a Depressão Periférica Paulista, com o relevo a norte e nordeste da bacia formado, predominantemente, por colinas amplas e a leste, por colinas médias e amplas. As planícies apresentam, com raras exceções, superfícies reduzidas e os remanescentes da vegetação original são raros.

A bacia do ribeirão Anhumas possui área aproximada de $150 \mathrm{~km} 2$, sendo que cerca de $50 \%$ desta área encontra-se urbanizada.

Esta bacia, afluente do Atibaia, corta o município no sentido norte-sul apresentando uma série de impactos que degradam seus afluentes, suas margens e os fundos de vale. O ribeirão Anhumas apresenta vários pontos de inundação, desde suas nascentes até a passagem sob a rodovia Dom Pedro I.

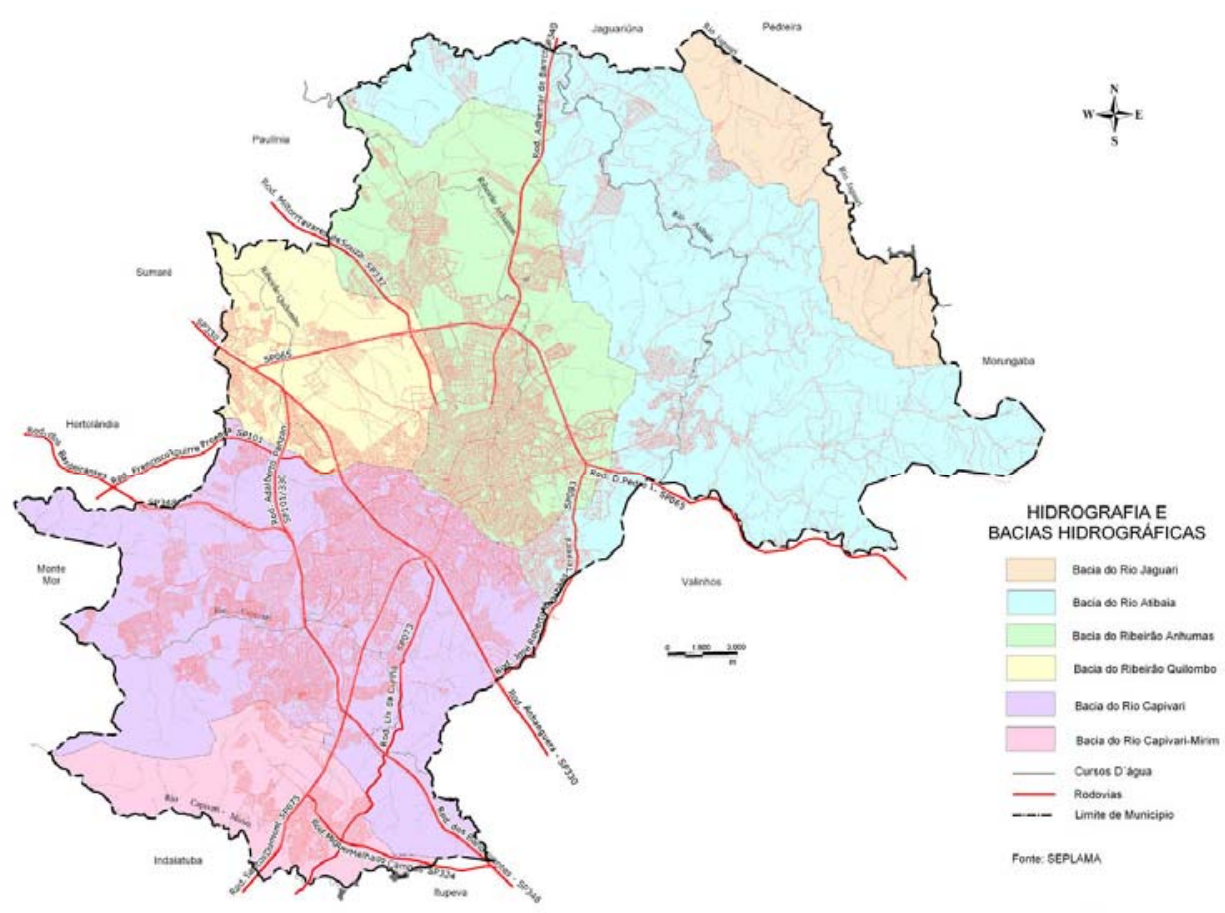




\section{Tendências}

Caracteriza-se por ter, espacialmente, uma importante tendência de crescimento e desenvolvimento municipal, em função da localização e expansão de pólos tecnológicos, universidades, novos loteamentos, áreas industriais e estabelecimentos comerciais de grande porte. Essa tendência é notada principalmente em áreas ao norte da bacia. A região sul destaca-se por ser uma área urbana densamente consolidada, onde se localiza toda a área central da cidade.

Ao longo e sua área de drenagem são encontrados loteamentos nos mais diferentes estágios de urbanização, desde toda a área central da cidade (próxima as nascentes) até loteamentos e bairros em processo de urbanização.

\section{Córregos}

Os córregos localizados em áreas centrais encontram-se canalizados ou revestidos, sem suas áreas de proteção permanente (APPs). Em geral, todos os canais que drenam a área urbana estão degradados, sendo neles despejado o esgoto sem nenhum tratamento. As áreas de baixada, várzeas naturais do ribeirão, encontram-se ocupadas principalmente por uma população de baixa renda, que sofre anualmente com os efeitos do período chuvoso. Na área rural, que está sob grande pressão de urbanização, a situação de degradação ambiental também é grande.

\section{Uso atual da terra}

Com relação ao uso atual das terras da bacia do ribeirão Anhumas, as áreas urbanizadas representam $46,44 \%$ da área total, enquanto as áreas verdes e lagos mapeados somam apenas 3,06\%. Os demais usos, como pasto e culturas, alcançam 50,50\%. As áreas urbanizadas da bacia, foram classificadas em: urbano denso, urbano e mediamente urbanizada.

\section{Fragmentos da Vegetação Original}

A melhor forma de conservar a biodiversidade é mantendo áreas suficientemente grandes para se auto-perpetuarem. 
Entretanto, áreas com estas características estão cada vez mais raras, e um exemplo da fragmentação da vegetação nativa pode ser encontrado na própria bacia do ribeirão Anhumas. Devido à reduzida quantidade de remanescentes, menos de 3\% da área da bacia, é extremamente importante a recuperação das áreas de APP e de reserva legal, de modo a não aumentar a área coberta com vegetação nativa, mas também aumentar a conectividade entre os fragmentos.

Uma possibilidade de manejo da paisagem, a fim de minimizar os efeitos dos processos de fragmentação/degradação é a chamada restauração ecológica de ecossistemas naturais, ou mais simplesmente, restauração florestal

A restauração pode ter um papel importante na conservação da biodiversidade, desde que haja um trabalho criterioso no estabelecimento de populações representativas de espécies nativas do local a ser restaurado. Para reconectar populações isoladas em fragmentos, é necessária a melhoria da rede de corredores verdes, seja construindo novos ou melhorando os já existentes e associar práticas de manejo florestal àquelas de restauração. A escolha de áreas a serem recuperadas deve ser feita com base na estrutura e no potencial de conectividade da paisagem.

È importante ressaltar que as áreas de preservação permanente são, sem dúvida, prioritárias para se restaurar, pois, agindo nessas áreas, é possível diminuir os riscos de extinção de espécies e restabelecer uma série de funções de uma paisagem equilibrada, evitando-se vastas erosões e cheias repentinas.

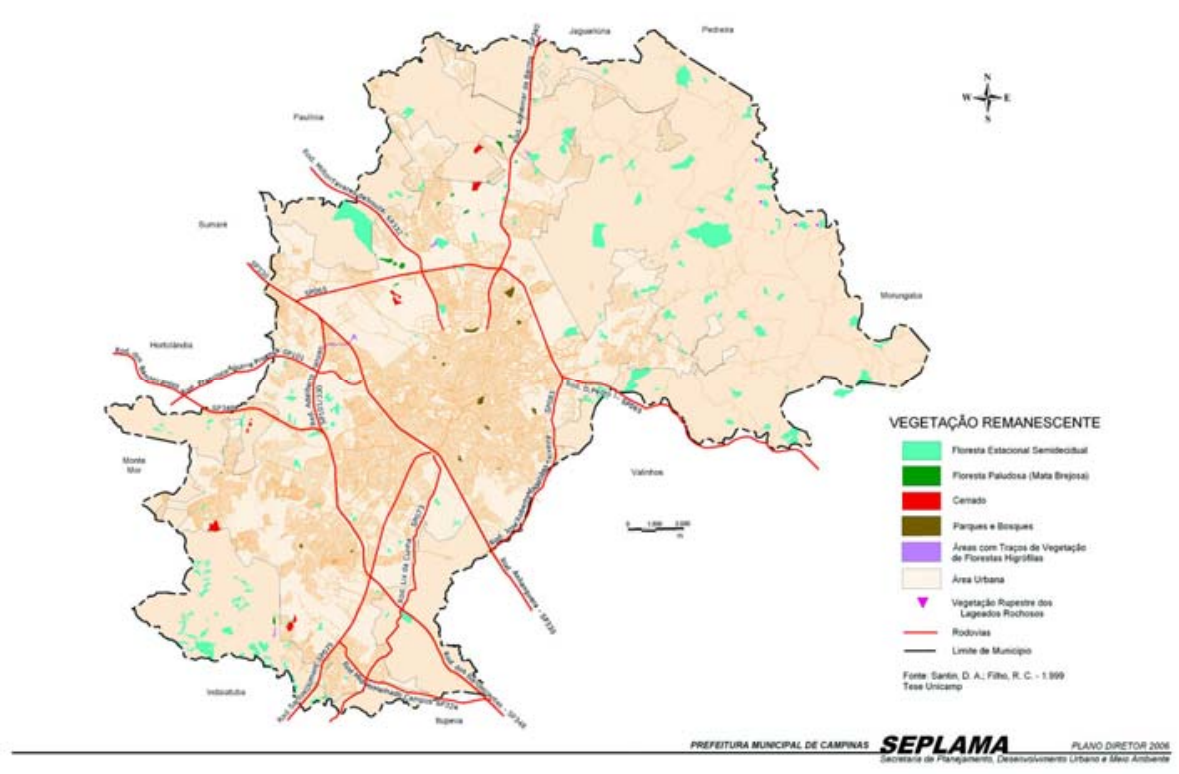

Imagem 15. Vegetação Remanescente em Campinas, Plano Diretor 2006 


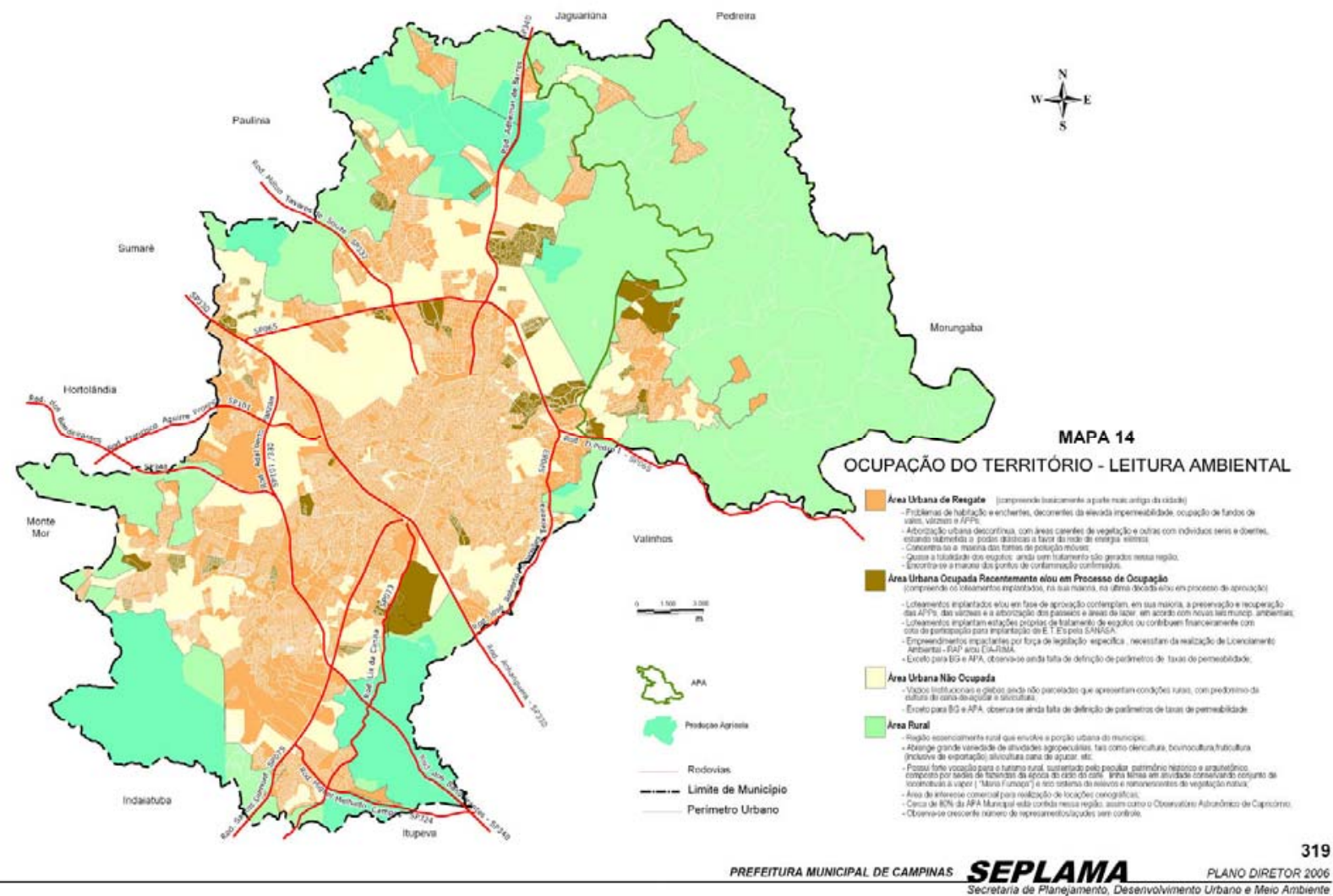

Imagem 16. Ocupação do território - Leitura Ambiental, Plano Diretor 2006

Visando atender esta premissa ambiental, o Plano Diretor de Campinas, revisado em 2006, propõe a criação de Eixos Verdes (ver imagem 06).

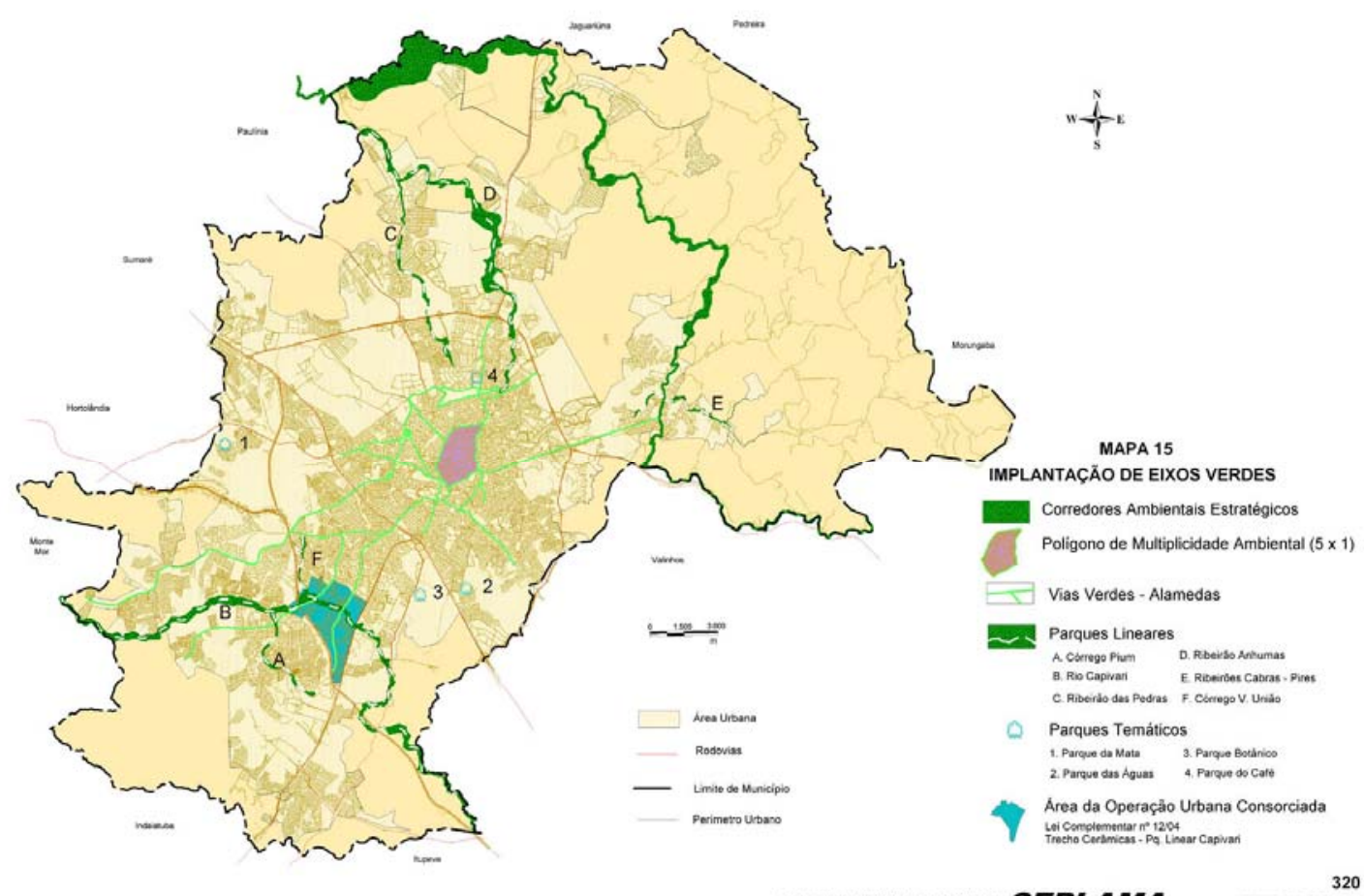

Imagem 17. Implantação de Eixos Verdes, Plano Diretor 2006 


\subsubsection{Questão da Urbanização Dispersa}

Torna-se necessário também analisarmos o caso específico da Urbanização Dispersa - Rodovia Dom Pedro I, uma vez que a área em estudo encontra-se em posição intermediária entre o Centro e a rodovia.

\section{Campinas e a Urbanização Dispersa - o caso da Rodovia Dom Pedro I:}

È possível analisar a Urbanização Dispersa em duas escalas, estudadas em suas especificidades e de modo integrado, como partes que são de um só processo. Segundo Nestor Goulart Reis Filho em "Urbanização Dispersa e mudanças no tecido urbano" em 2006:

- Escala da Área Metropolitana - a dispersão se define como a dispersão da cidade, onde se definem as polarizações, os eixos de transporte de passageiros e as formas diferenciadas de apropriação do espaço urbano pelas classes sociais.

- Escala do Tecido Urbano - é onde se define a posse do espaço urbano e a produção material, bem como apropriação, uso e transformação desse espaço. São essas relações que se definem nos projetos e obras.

A Dispersão Urbana, na Escala Metropolitana, pode ser caracterizada preliminarmente, pelos seguintes tópicos:

- Esgarçamento crescente do tecido dos principais núcleos urbanos em suas áreas periféricas;

- Formação de "nebulosas" de núcleos urbanos e bairros isolados em meio ao campo, de diferentes dimensões, integrados em uma área metropolitana ou em um sistema de áreas metropolitanas;

- Pelas mudanças no transporte diário intermetropolitano de passageiros, que transformou as vias de transporte interregional de modo a se tornarem grandes vias expressas inter e intrametropolitanas;

- Pela difusão de modos metropolitanos de vida e de consumo, também estes dispersos pela área metropolitana. 
A situação da Rodovia Dom Pedro I, em Campinas, é um caso emblemático da realidade da Urbanização Dispersa. A área do entorno deste importante eixo torna-se exceção frente ao contexto de desenvolvimento da cidade, tornando-se um eixo de grande desenvolvimento.

Na Escala do Tecido Urbano, ficam evidentes as novas formas de organização do tecido urbano, com o surgimento de empreendimentos de grande porte que, segundo o mesmo autor citado:

- Freqüentemente utilizam os princípios propostos pelo Movimento Moderno com outros objetivos, por iniciativa do capital privado e não de agências estatais, como anteriormente;

- São destinados à atender a demanda dos setores de renda alta e médias e não os de baixa renda, como anteriormente;

- Atendem a usos habitacionais mas também a usos comerciais, industriais, de lazer e cultura;

- Geram novas centralidades;

- Adotam formas condominiais complexas;

- Geralmente reúnem duas ou mais formas de uso.

A seqüência de imagens ilustram o caso da rodovia Dom Pedro I:

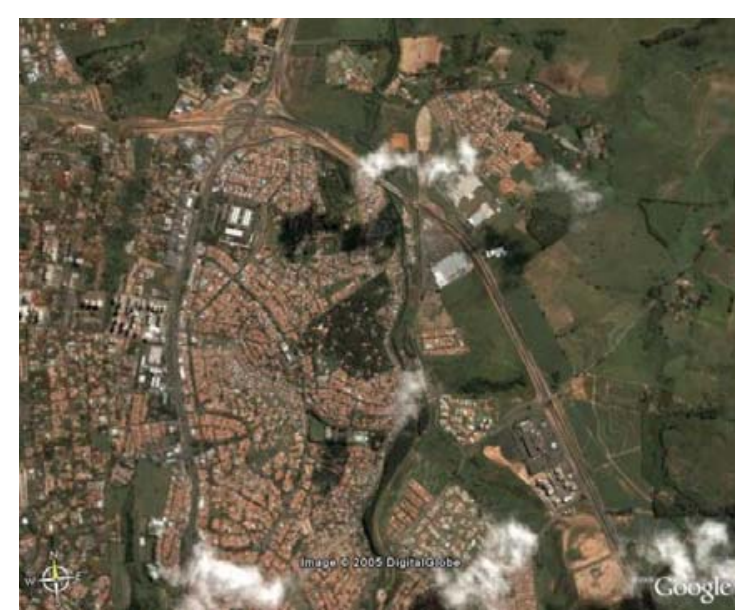

Carrefour e Shopping Galleria

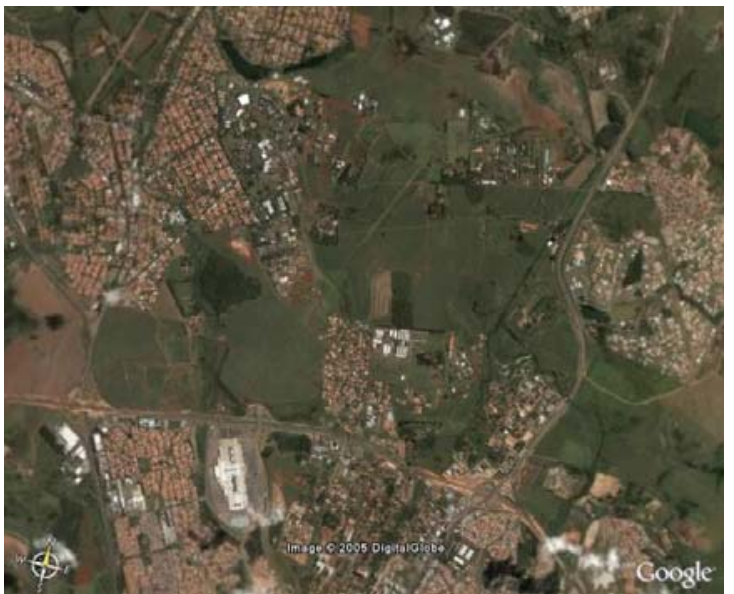

Vista aérea do Ciatec e LNLS 

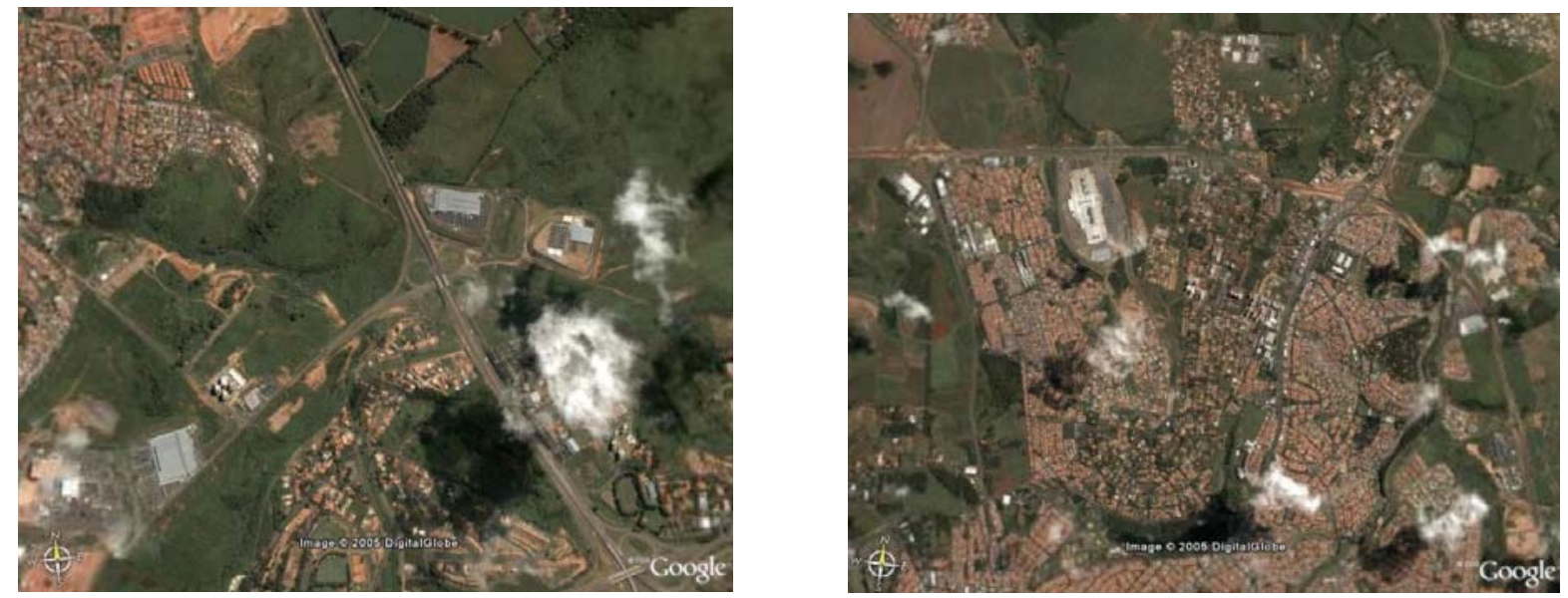

Vista Dom Pedro I - Shopping Iguatemi - Leroy Merlin e Shopping Dom Pedro I

\section{Valorização da Campinas Contemporânea: Eixo da Rodovia Dom Pedro I}
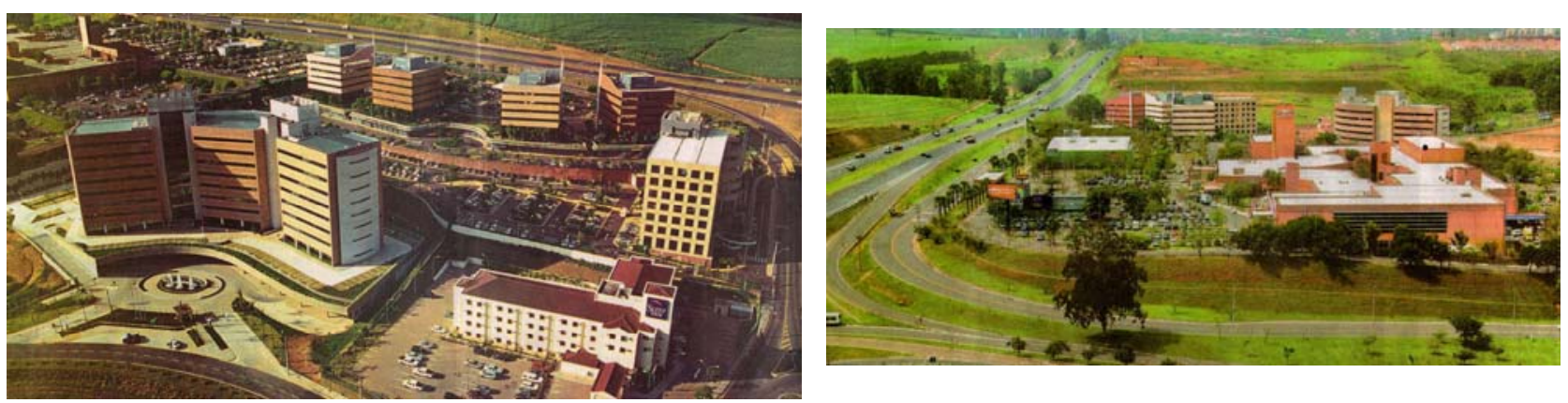

Imagem 18 e 19: Complexo Galleria Office Park e Shopping Galleria

A valorização do eixo da rodovia Dom Pedro I está inserida no contexto regional de circulação de mercadorias e pessoas, configurada como importante conexão do interior do estado.

As tabelas abaixo, segundo o jornal Correio Popular, contém dados ilustrativos sobre o poder de atração de investimentos na área, cerca de $R \$ 2,5$ bilhões de reais somente na última década ${ }^{110}$.

\begin{tabular}{|l|l|}
\hline Empreendimentos Comerciais/ Serviço & Investimento ( R\$) \\
\hline Galleria Office Park & 115 milhões \\
\hline Galleria Corporate, e Galleria Shopping & 50 milhões \\
\hline Shopping Parque Dom Pedro & 310 milhões \\
\hline Condomínio Praça Capital & 60 milhões \\
\hline Leroy Merlin & 15 milhões \\
\hline Decathlon & 10 milhões \\
\hline
\end{tabular}

\footnotetext{
${ }^{110}$ JORNAL CORREIO POPULAR - "Novos pólos de desenvolvimento de Campinas". 30 de outubro, Campinas, 2005.
} 


\begin{tabular}{|l|l|}
\hline Empreendimentos Residenciais & Investimento (R\$) \\
\hline Bougainville 01 & 100 aptos de 450 mil \\
\hline Bougainville 02 & 380 residências de 1 milhão \\
\hline Alphaville 01 & 1700 residências de 800 mil \\
\hline Gallery & 30 residências de 1 milhão \\
\hline Vila Verde & 200 residências de 1 milhão \\
\hline Alphaville 02 & 500 residências de 150 mil \\
\hline Seasons & 22 residências de 700 mil \\
\hline Casas D'Itália e Inglesas & 300 residências de 300 mil \\
\hline
\end{tabular}

\begin{tabular}{|l|l|}
\hline Empreendimentos Industriais & Investimento (R\$) \\
\hline Techno Park & 200 milhões \\
\hline Samsung & 500 milhões \\
\hline Lucent & 500 milhões \\
\hline
\end{tabular}
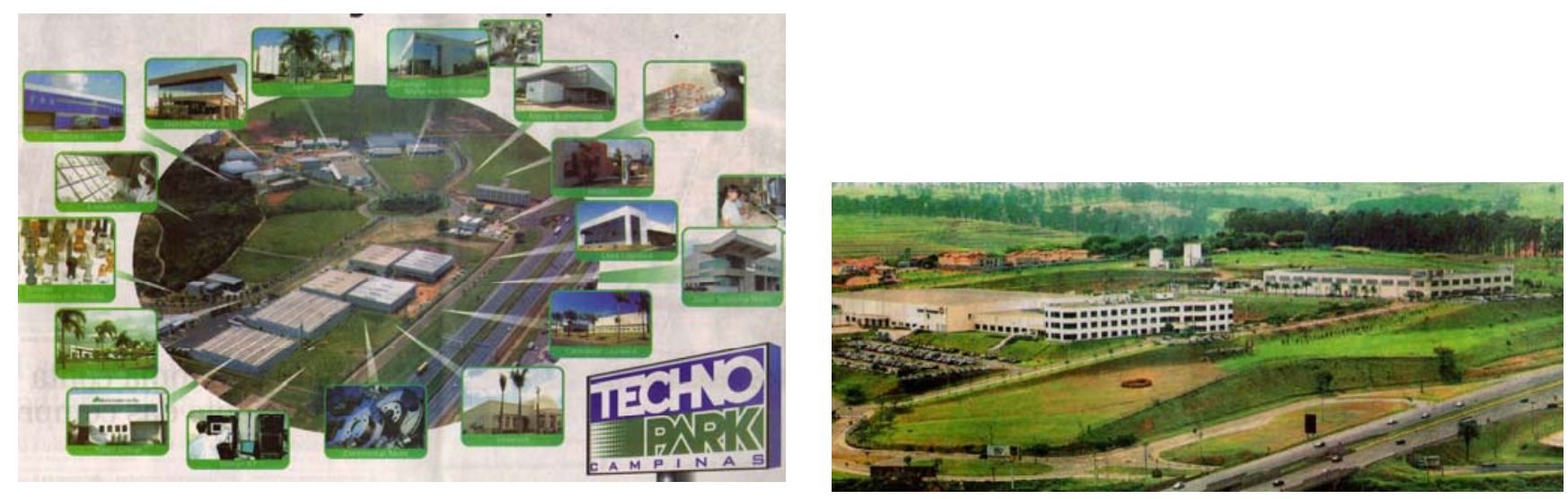

Imagem 20 e 21: Complexo Techno Park e Empressa Lucent

A tabela abaixo, conforme o jornal Correio Popular, contém índices comparativos demonstrando a intensa valorização imobiliária ocorrida na última década ao longo da Rodovia Dom Pedro I, atingindo todos os segmentos do mercado imobiliário ${ }^{111}$.

\begin{tabular}{|l|l|l|l|}
\hline Local & Valor Inicial & Valor Atual & \% ao ano \\
\hline Galleria Office Park & $\mathrm{R} \$ 1,7 \mathrm{mil} / \mathrm{m} 2$ & $\mathrm{R} \$ 3,5 \mathrm{mil} / \mathrm{m} 2$ & $15 \%$ \\
\hline Lotes Vila Verde & $\mathrm{R} \$ 30 \mathrm{mil}$ & $\mathrm{R} \$ 300 \mathrm{mil}$ & $25 \%$ \\
\hline Lotes Alphaville 01 & $\mathrm{R} \$ 70 \mathrm{mil}$ & $\mathrm{R} \$ 250 \mathrm{mil}$ & $23 \%$ \\
\hline Lotes Bouganville & $\mathrm{R} \$ 70 \mathrm{mil}$ & $\mathrm{R} \$ 400 \mathrm{mil}$ & $17 \%$ \\
\hline
\end{tabular}

${ }^{111}$ JORNAL CORREIO POPULAR. op. cit. 


\section{CAPÍTULO 03 - ESTUDO DE CASO: CONTRIBUIÇÃO AO PROJETO URBANO ANHUMAS}

Neste capítulo apresento os motivos da escolha da área de estudo, bem como uma leitura da área na escala local e por fim a contribuição ao Projeto Urbano Anhumas.

\subsection{Definição da área de estudo}

Como conseqüência da análise histórica do desenvolvimento de Campinas, observamos claramente a existência dos vazios urbanos ao longo dos trilhos gerados com a desativação das ferrovias ocorrida quando da mudança de prioridades, de transporte ferroviário para rodoviário, no modelo de desenvolvimento brasileiro e da dinâmica de urbanização ocorrida.

Num breve relato do desenvolvimento da malha ferroviária de Campinas, podemos ressaltar:

A instalação de diferentes companhias férreas em Campinas, se deu a partir de 1872, com a inauguração da ligação entre Campinas e Jundiaí (portanto ao porto de Santos) pela Companhia Paulista. A Mogiana (1875), Ramal Férreo (1889), Funilense (1899) e Sorocabana (1921) consolidam Campinas como "entroncamento ferroviário" no interior do Estado.

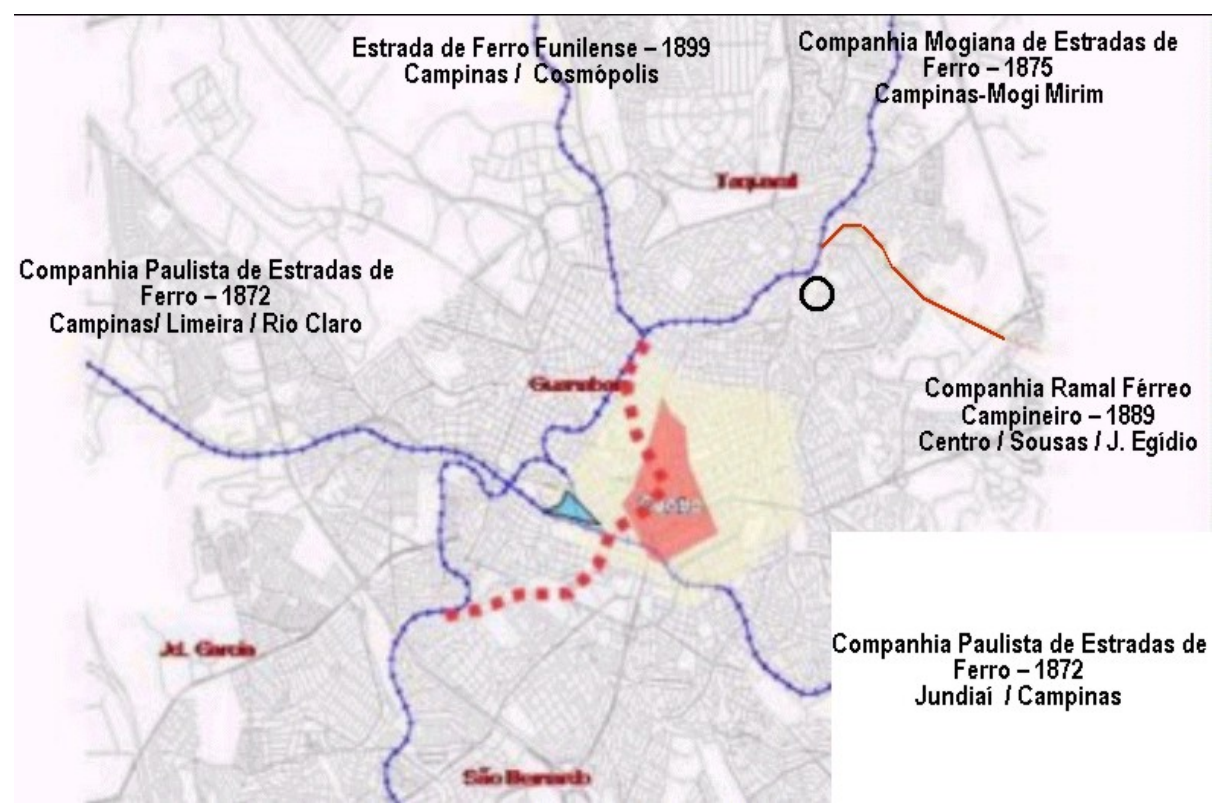

Imagem 22: Mapa atual ilustrado com os Leitos ferroviários e com círculo indicando a Área de Estudo. 
A partir da década de 1950, as mudanças operadas na área de transporte começaram a transferir para o setor rodoviário o papel até então desempenhado pelas ferrovias.

No início da década de 1970, as antigas estradas de ferro foram incorporadas à Fepasa, e, no curso da década de 1980, a malha ferroviária começou a ser concessionada.

A partir de então, a desestruturação e desativação dos serviços colocou em risco a sobrevivência do conjunto histórico, arquitetônico e urbanístico do complexo ferroviário, ameaçado pelo abandono e pela especulação imobiliária.

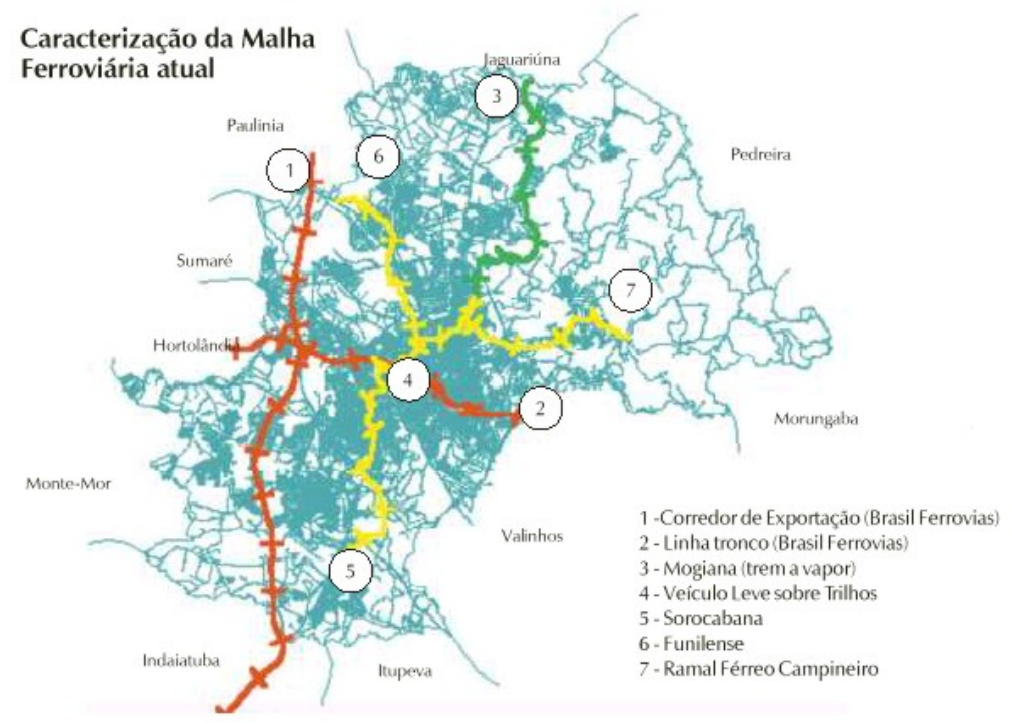

Imagem 23: Malha Ferroviária atual - em vermelho o fluxo de carga, em amarelo os leitos desativados e em verde o leito com função turística até a cidade de Jaguariúna.

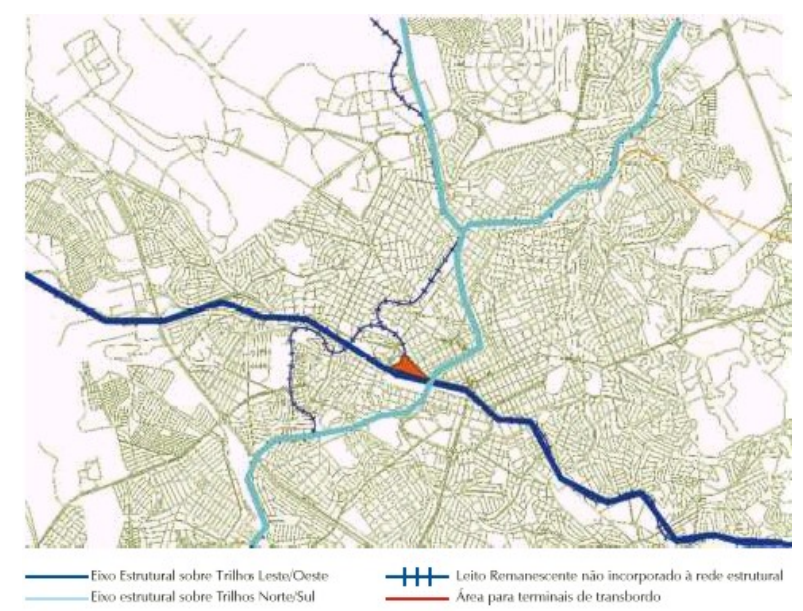

Imagem 24: Leitos na Área Central 

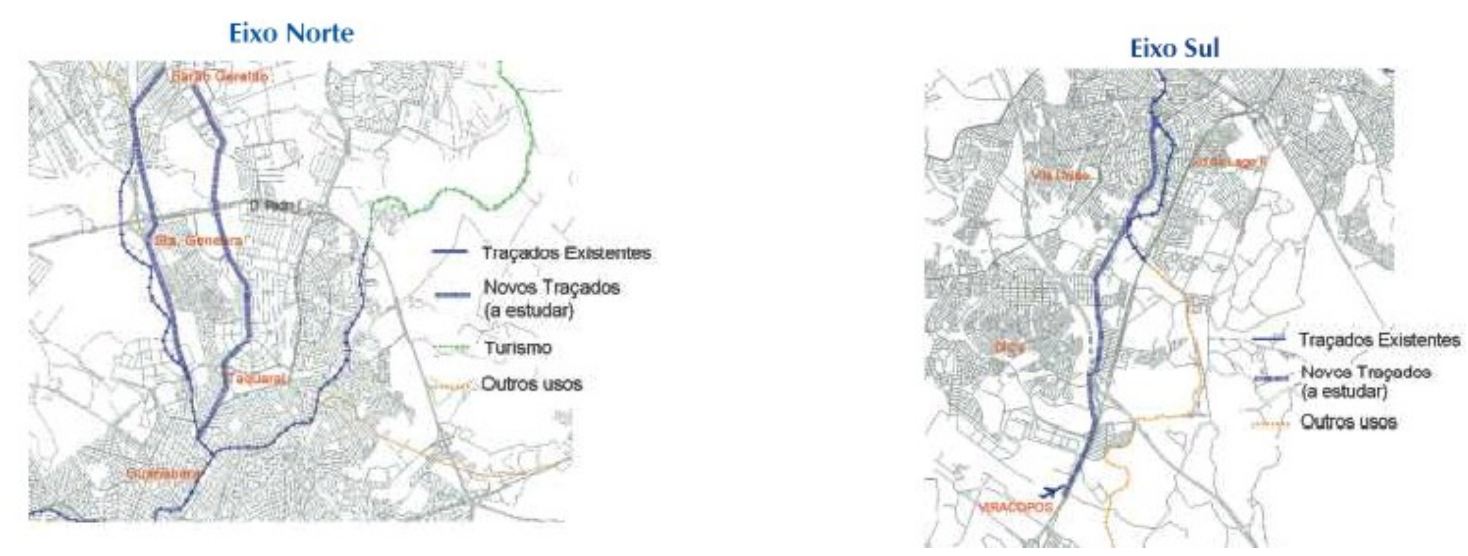

Imagem 25,26: Leito Norte e Leito Sul

\section{Situação atual dos leitos}

Dos quase $93 \mathrm{~km}$ de ramais ferroviários anteriormente operacionais, atualmente $44 \mathrm{~km}$ estão desativados, gerando cerca de 50 terrenos dos mais variados tamanhos, compondo esses vazios.

Como referência, podemos citar a existência de 8 terrenos com área de 662 mil m2 ainda sem destinação de uso, variando de 13 mil a 230 mil m2, conforme exemplos a seguir:

- Entorno da antiga Estação Central que mesmo tendo parte já utilizada, onde ficam a Estação Cultura, antiga Estação Central, o Ceprocamp e as obras da nova Rodoviária e Terminal Metropolitano em fase final de conclusão, ainda dispõe de cerca de $300.000 \mathrm{~m} 2$ a serem re-urbanizados.

- Trechos que já foram reutilizados com o Veículo Leve sobre Trilhos (VLT) Norte e VLT Sul, que com a constatação da inviabilidade econômica do empreendimento, voltaram a ser abandonados e por conseqüência sofreram o processo de degradação. São duas áreas com $80.000 \mathrm{~m} 2$ cada uma nos bairros Bonfim, V. Teixeira e Guanabara no ramal Norte e, Parque Industrial e Campos Elíseos no ramal Sul,

- Trechos reativados parcialmente dentro do uso inicial, ou seja, linhas ferroviárias, como o da antiga Mogiana, onde foi implantada a linha turística Maria- 
Fumaça que liga Campinas a Jaguariúna, resultando numa área degradada de $30.000 \mathrm{~m} 2$.

- O entorno da Estação Guanabara, da mesma Mogiana com 103.000 m2 que foi objeto de diversos estudos e propostas de uso diversificado, mas que até o momento encontra-se abandonada.

- Duas áreas situadas no Taquaral, no entorno do leito da extinta Fepasa, somando cerca de $70.000 \mathrm{~m} 2$.

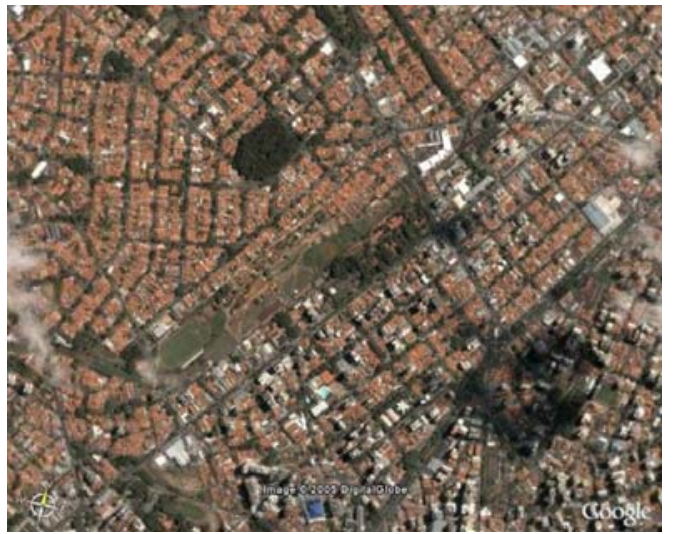

Imagem 27. Vazio Leito Guanabara

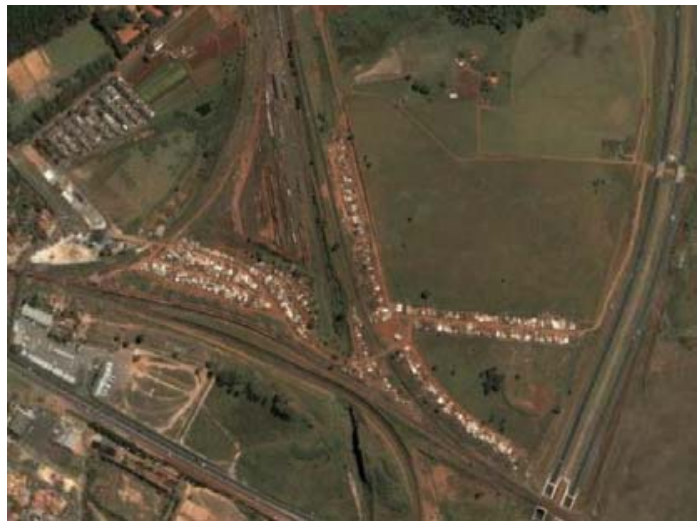

Imagem 29. Vazio Leito Aparecidinha

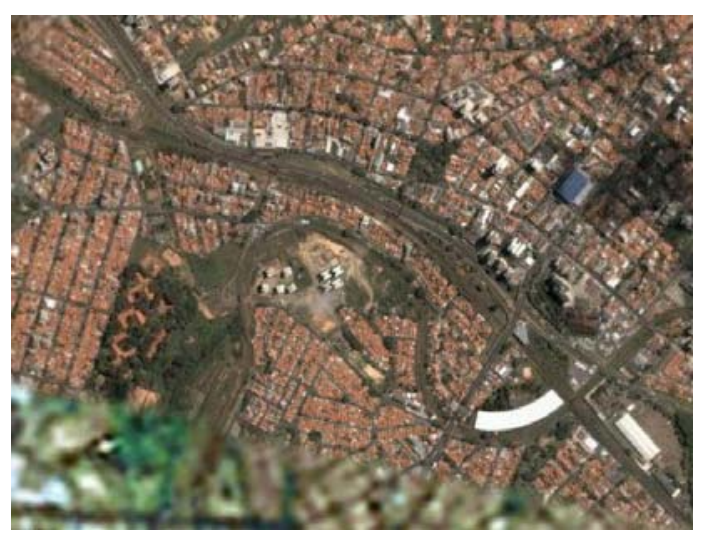

Imagem 28. Vazio Urbano Leito Sul

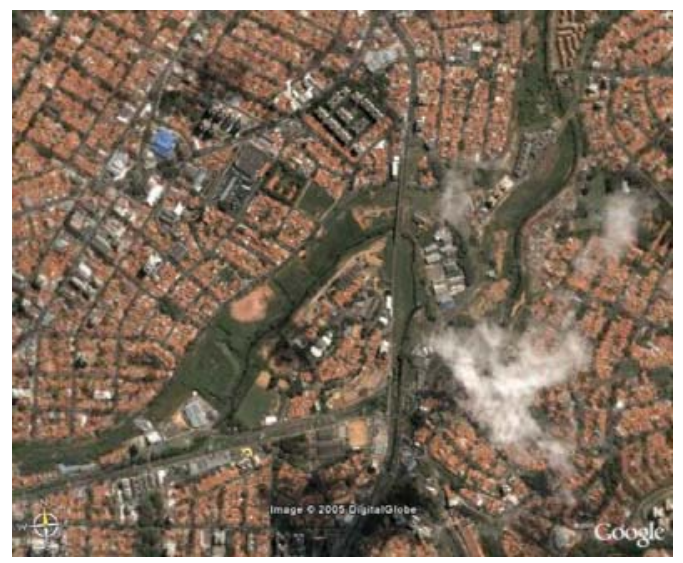

Imagem 30 Vazio Urbano Av. Norte Sul

\section{Deslocamentos - transporte de massa}

Aprofundando o panorama da situação atual, estudos efetuados pela EMDEC maperam as necessidades de deslocamento da população de Campinas e região, através de pesquisas de Origem/Destino. Os resultados evidenciam os 
trechos prioritários no processo de implantação das soluções de transporte de massa, em escala metropolitana e municipal.

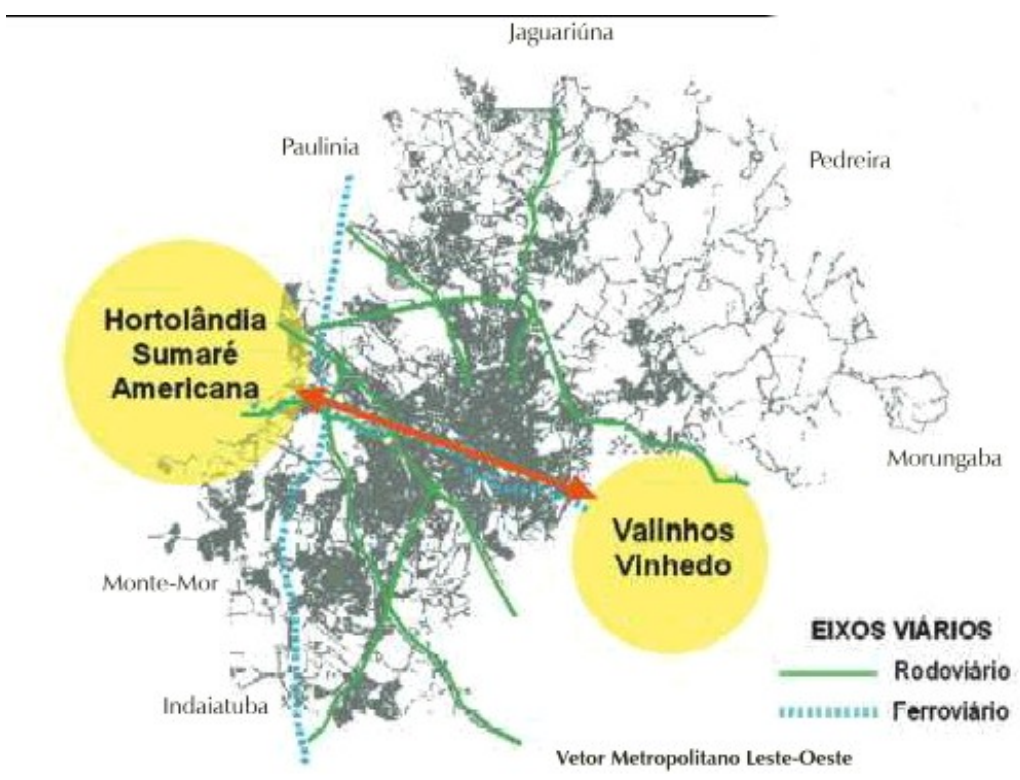

Imagem 31: Vetor Metropolitano Leste-Oeste

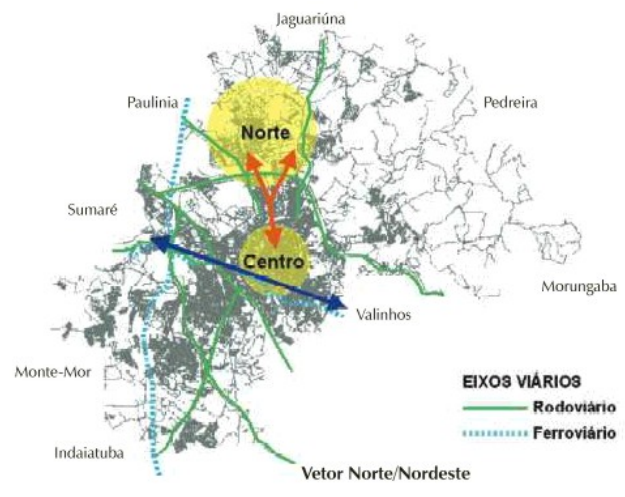

Imagem 32: Vetor Norte/ Nordeste

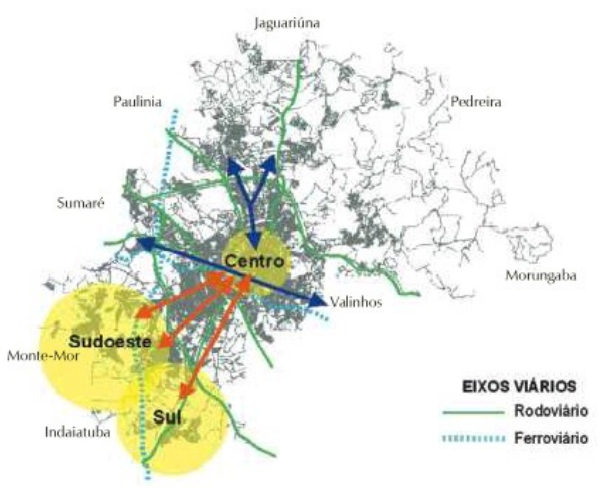

Imagem 33: Vetor Sul /Sudoeste

Novas centralidades e novas polaridades

Com a sobreposição do mapeamento do deslocamento da população com o mapeamento da infra-estrutura sub-utilizada dos leitos desativados, constata- 
se que, em grande parte, os deslocamentos da população coincidem com a infraestrutura instalada.

Esta cenário em potencial foi expresso em estudos realizados pela Prefeitura de Campinas, que priorizavam a reutilização dos leitos ferroviários desativados. Os leitos seriam ligações entre as diferentes partes da Região Metropolitana, de forma ainda mais abrangente do que a de transportes, pois seriam os potenciais indutores e qualificadores da urbanização:

\begin{abstract}
"Campinas possui aproximadamente $44 \mathrm{Km}$ de Leitos Férreos desativados, distribuídos por diferentes regiões do município, em sua maior parte caracterizadas por forte urbanização. Esses leitos localizam-se nas regiões Sul, Norte, Nordeste e Leste, e constituemse quase que de maneira natural, tramos de uma rede. Desativados nas décadas de 60 e 70, ainda hoje boa parte dos leitos encontramse desimpedidos, mas caracterizando-se como barreiras no processo de expansão urbana. Dessa forma, cumpre utilizar esse raro patrimônio físico disponível como suporte das ligações ferroviárias, evitando que a expansão urbana e a especulação imobiliária dela se aproprie."
\end{abstract}

Dentre as várias propostas previstas neste Plano está a definição de núcleos urbanizados, denominados "Novas Centralidades", ao longo dos eixos ferroviários, que deverão valorizar e requalificar porções do território da cidade, redefinindo os investimentos em infra-estrutura bem como sua relação com a área central do município ${ }^{112}$.

${ }^{112}$ CAMPINAS, Prefeitura Municipal. "Sistema Estrutural de Transporte de Campinas" Publicação em Novembro 2003 


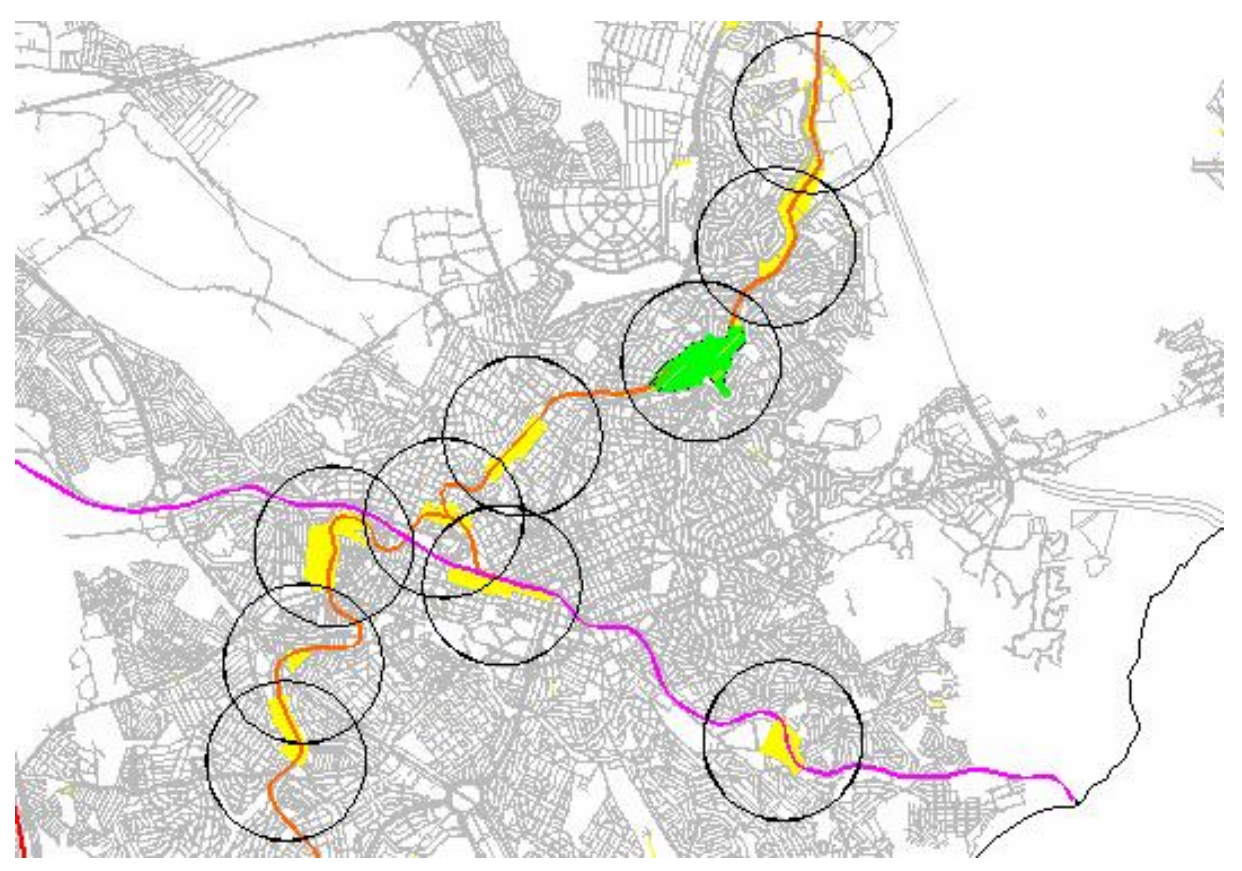

Imagem 34: Situação atual dos vazios urbanos ao longo dos eixos ferroviários

Dada a quantidade de pontos identificados, situados por boa parte da Campinas, nos parece importante estudar alternativas de uso e integração destas áreas com a cidade e as cidades da Região Metropolitana

\section{Definição da área de estudo}

A escolha do vazio urbano situado próximo ao entroncamento da Av. Norte Sul com a Av. Orozimbo Maia se deve, basicamente pela reunião de três fatores: sua localização - entre a região central e a urbanização dispersa do entorno do Anel Viário, o interesse da iniciativa privada na região, que apresenta investimentos e desenvolvimento econômico diferenciado, e a complexidade apresentada devido à degradação ambiental do seu entorno imediato.

Configura-se portanto, como possível área de qualificação da área central, configurada como borda do centro, segundo Solà-Morales: “... algumas das mais importantes ações materiais de transformação, têm lugar na bordas dos centros, não dentro e nem demasiado longe deles." ${ }^{113}$ 

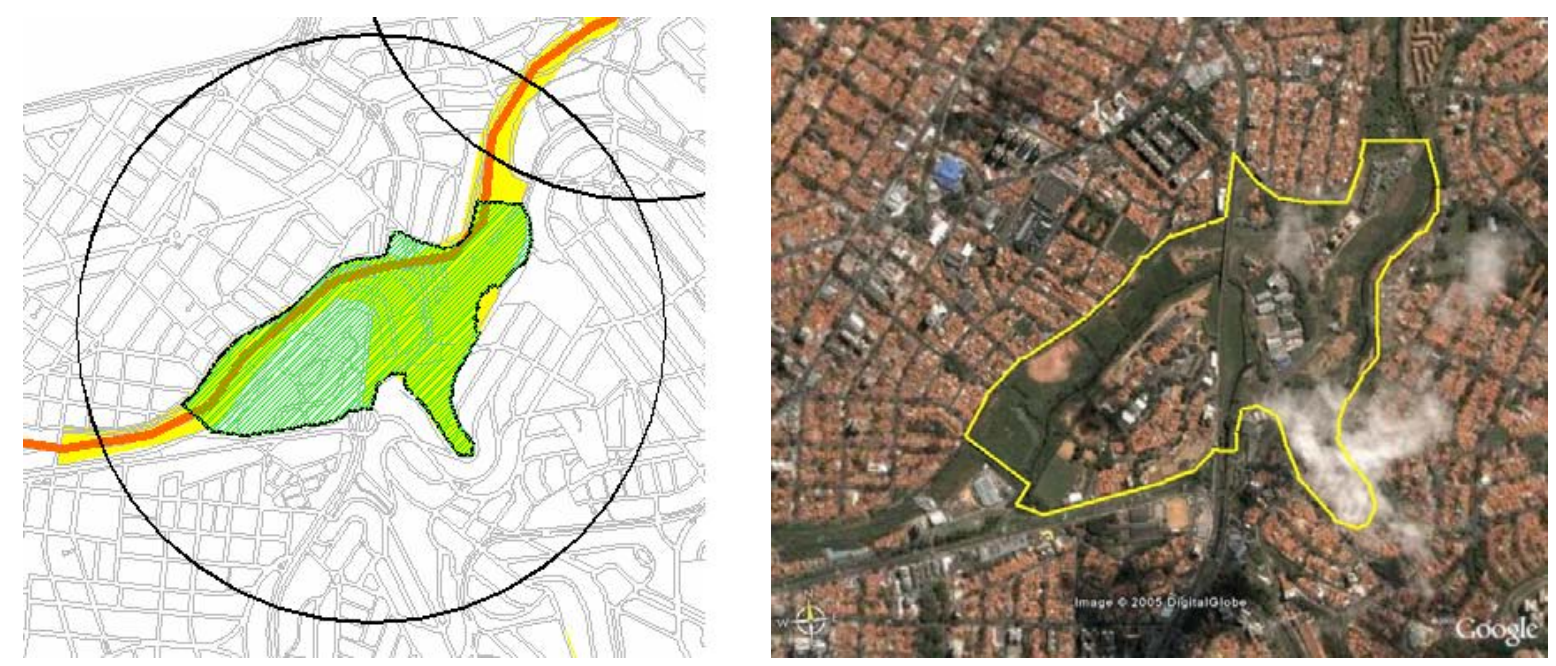

Imagem 35 e 36: Área de estudo em planta e vista aérea.

\subsection{Configuração da estruturação urbana atual - Análise da área de estudo na escala local}

\section{Descrição}

O "Projeto Urbano Anhumas" ocupa uma área de aproximadamente 67 hectares $(667.318,88 \mathrm{~m} 2)$. O recorte da área foi definido pelas limites entre as bordas edificadas da cidade e o vazio urbano, ressalvando a área consolidada junto ao entroncamento entre a Av Norte Sul e a Av. Orozimbo Maia, ao sul da área.

\section{Os limites}

Os limites da área de estudo foram definidos pela linha ferroviária desativada existente, no sentido suleste / noroeste da área. Ao norte da área, definida pelo limite da área urbanizada existente, até o limite nordeste, delimitado pela divisa do lote do conjunto habitacional e a ponte sobre o Ribeirão Anhumas. No sentido norte/sul, acompanha a os limites do bairro existente, contornando o bosque existente (em forma de gota na imagem abaixo). No sentido leste / oeste, é definido pelo entroncamento da av. Norte Sul com a Orozimbo Maia e, ao longo desta até a ponte sobre o Canal de Saneamento e desta, ao longo da divisa do lote no sentido sul / noroeste até reencontrar o leito ferroviário. A configuração atual é de área

\footnotetext{
${ }^{113}$ SOLÁ-MORALES, Ignasi de. "Ações estratégicas de reforço do centro". Ciclo de Palestras São Paulo, 1995.
} 
degradada ambientalmente, inclusive contendo invasões irregulares. A gleba fragmenta a malha urbana, gerando ilhas isoladas de degradação urbana.

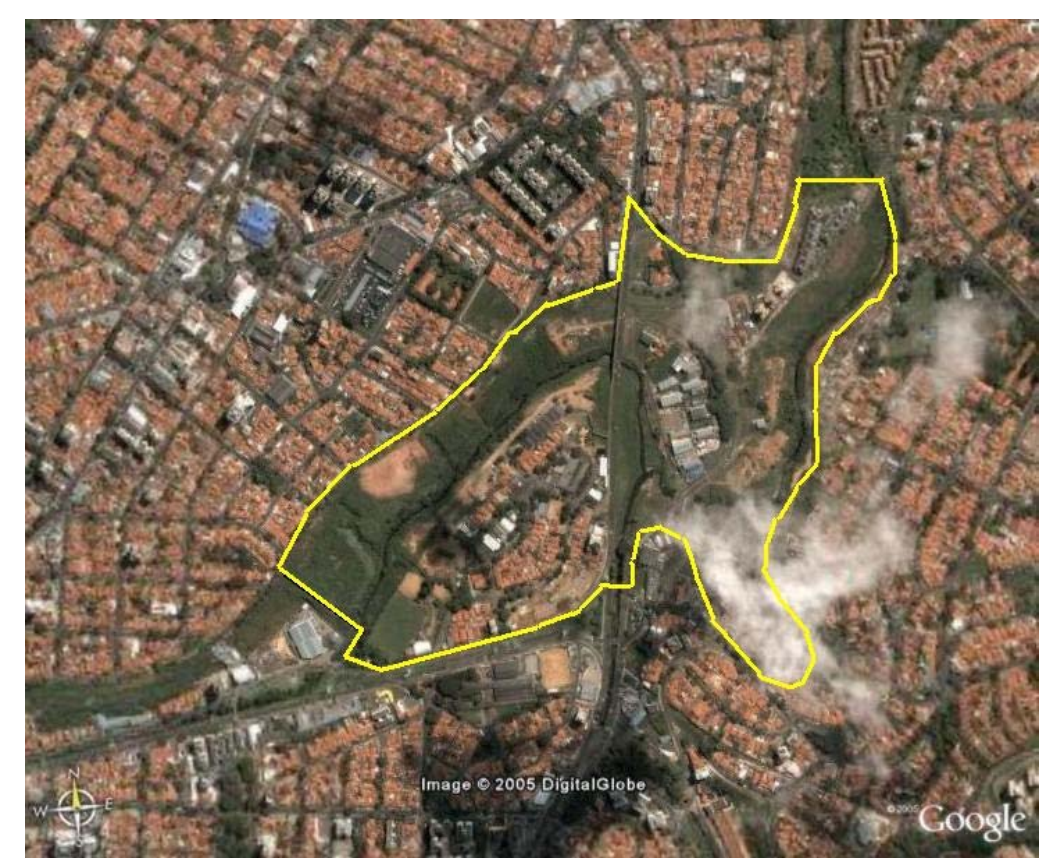

Imagem 37: Vazio Urbano objeto de estudo do Projeto urbano Anhumas. (Google Earth 2005)

\section{Localização da Área de Estudo}

Situada na porção Nordeste do território do município de Campinas (ver Imagem 01 e 02), a área de estudo do Projeto Urbano Anhumas encontra-se na Macrozona 04, caracterizada pelo alto grau de urbanização. 


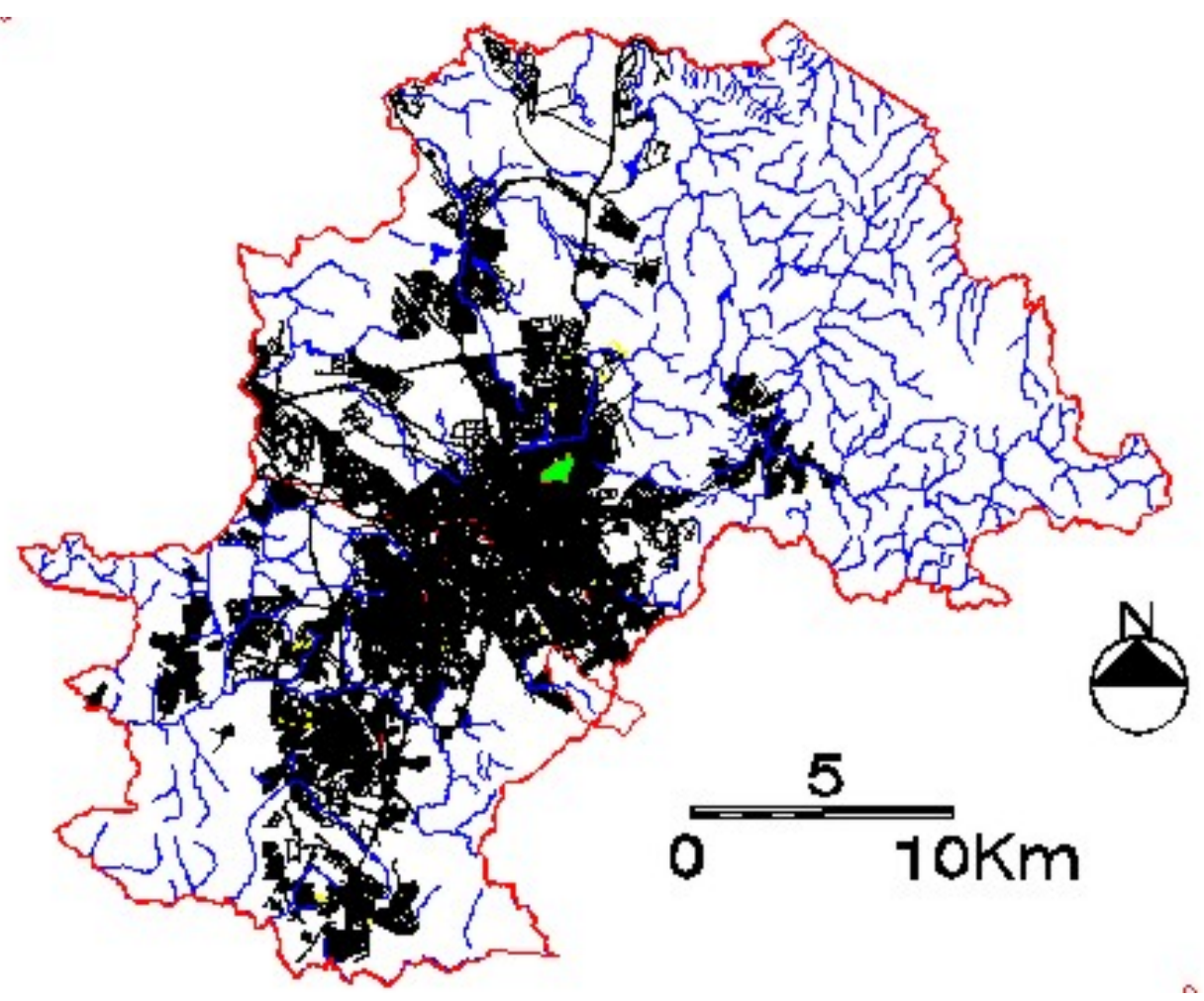

Imagem 38: Município de Campinas, com área de estudo sinalizada em verde. ( Seplama Campinas, editado pelo autor)

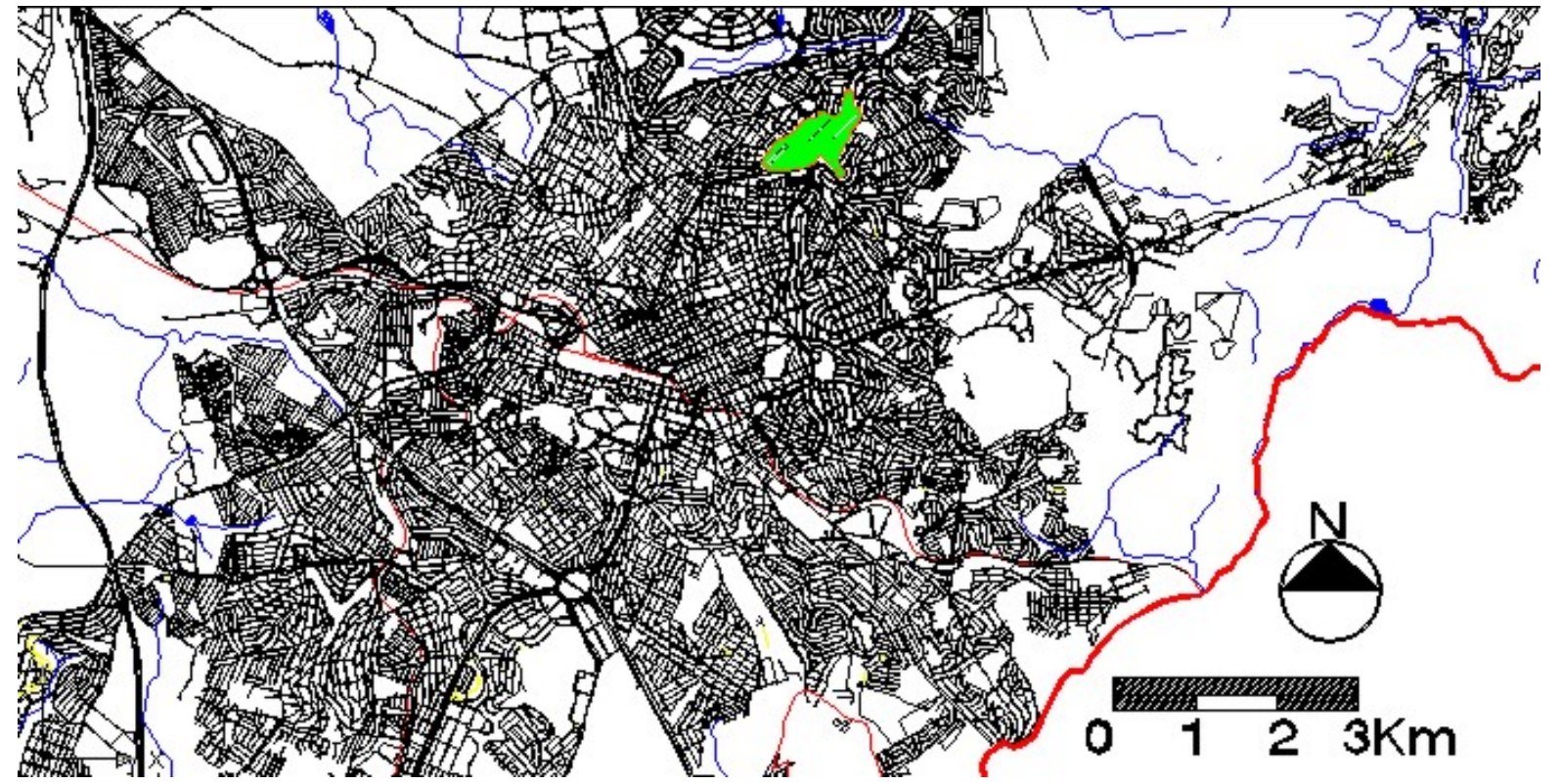

Imagem 39: Malha Urbana com Área de Estudo sinalizada em verde. (Seplama Campinas, editado pelo autor).

Distante cerca de apenas 3 km do "Centro Verticalizado", considerado "Centro Expandido", está situada no segundo anel de circulação do Sistema Viário de Rótula de Campinas (ver imagem 03), no entroncamento de duas importantes avenidas: Av. Orozimbo Maia e Av. Norte Sul (Ver imagens 04, 05, 06 e 07). 


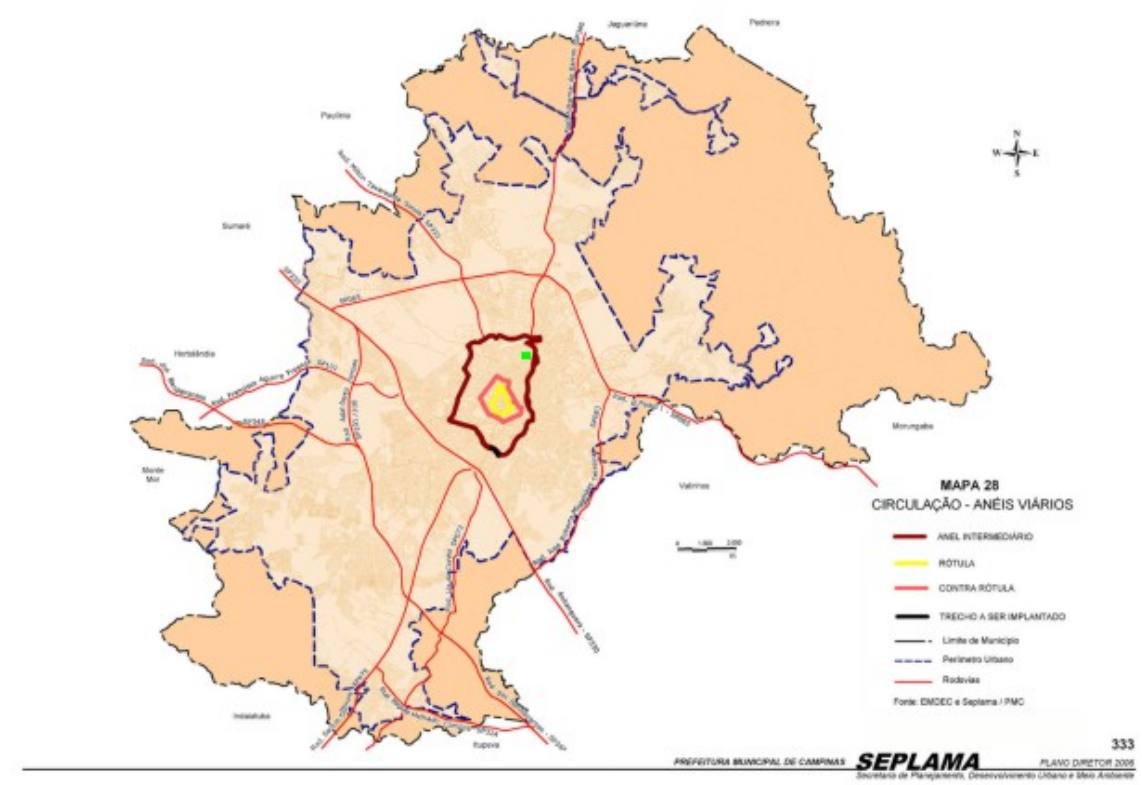

Imagem 39 A: Sistema de Circulação - Anéis Viários - Área de estudo sinalizada em verde. (Seplama Campinas, editado pelo autor).

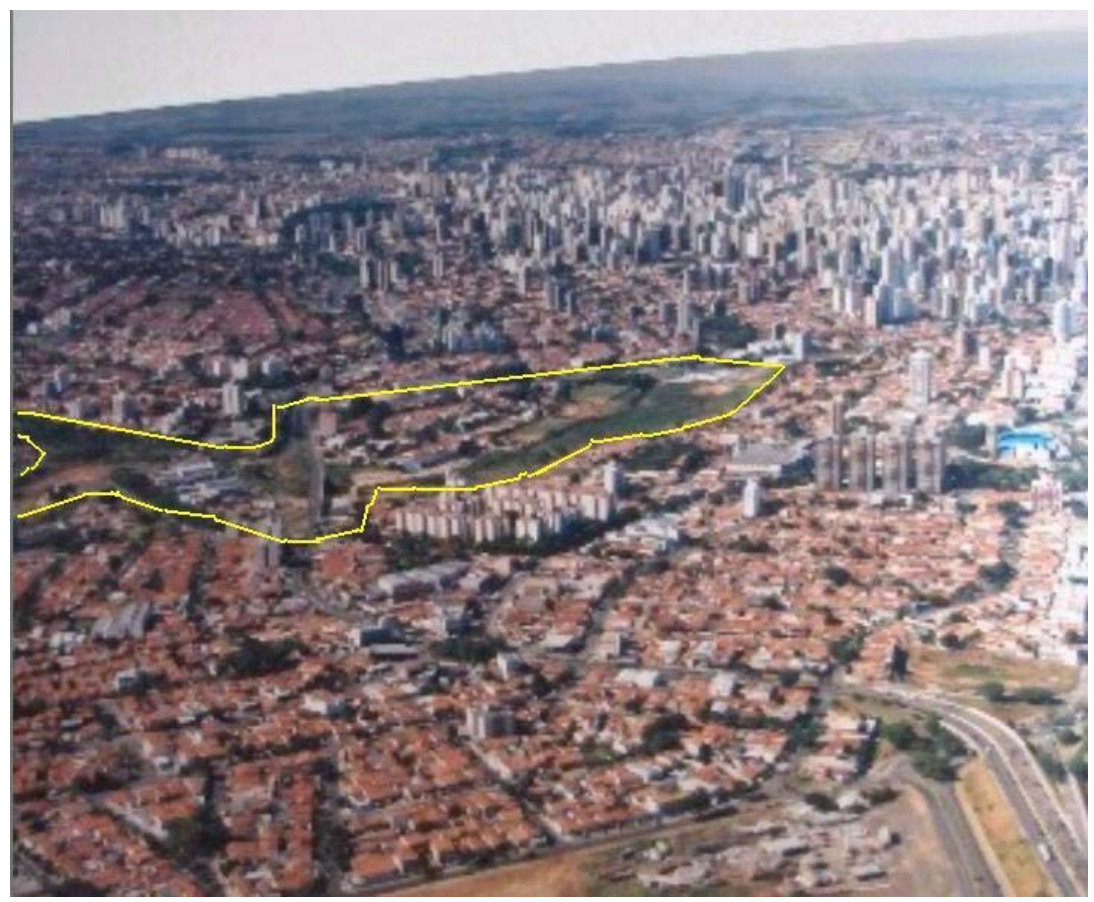

Imagem 40: Centro Consolidado ao fundo e vista da área de estudo configurada como um grande vazio urbano (delimitada em amarelo, no centro da foto) (www. rodrigoruiz.com.br) 


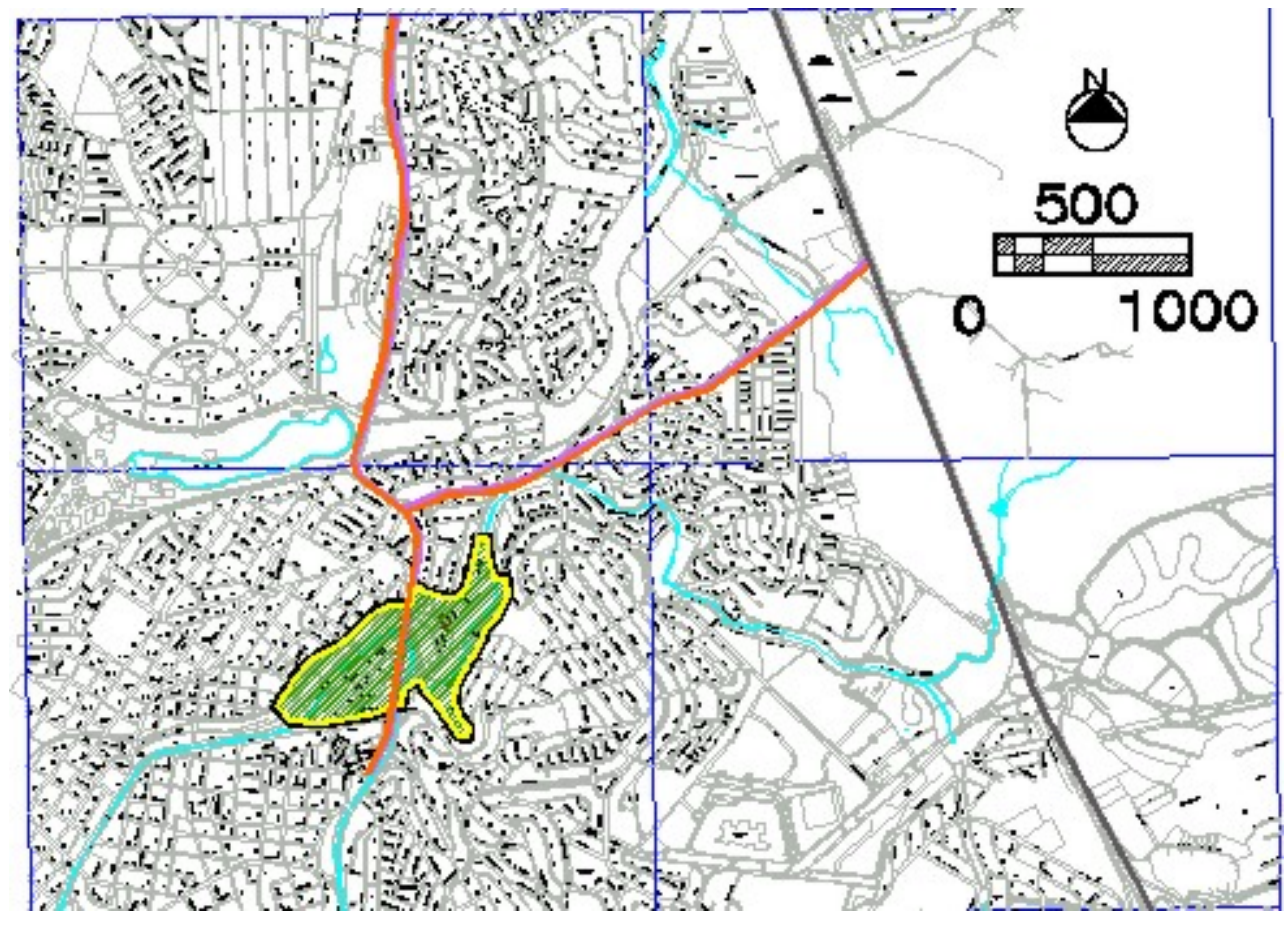

Imagem 41: Área do Projeto Urbano Anhumas (em verde) e as avenidas expressas de conexão ao Anel Viário. (Seplama editado pelo autor)

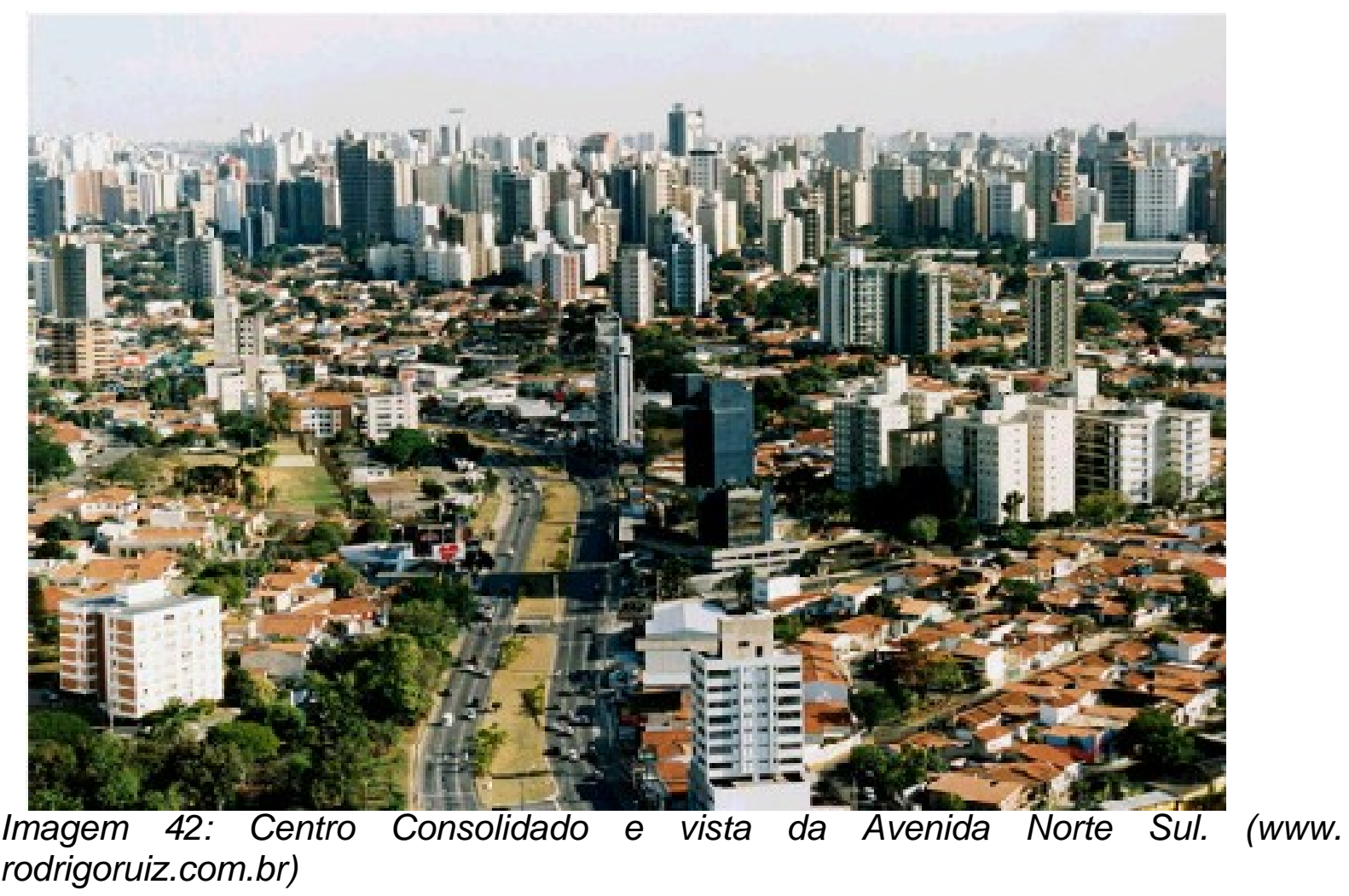




\subsubsection{A questão da Dispersão Urbana}

A área apresenta importante característica de articulação urbana devido ao fato de se situar próxima ao centro consolidado assim como se conectar através de via expressa - ao Anel Viário de Campinas, formado por importantes rodovias como a Dom Pedro I , Anhanguera e Bandeirantes. Esta situação permite a consideração de novos usos, sejam na escala do bairro ou da cidade, como também na escala da Região Metropolitana de Campinas (RMC),formada por 19 municípios.

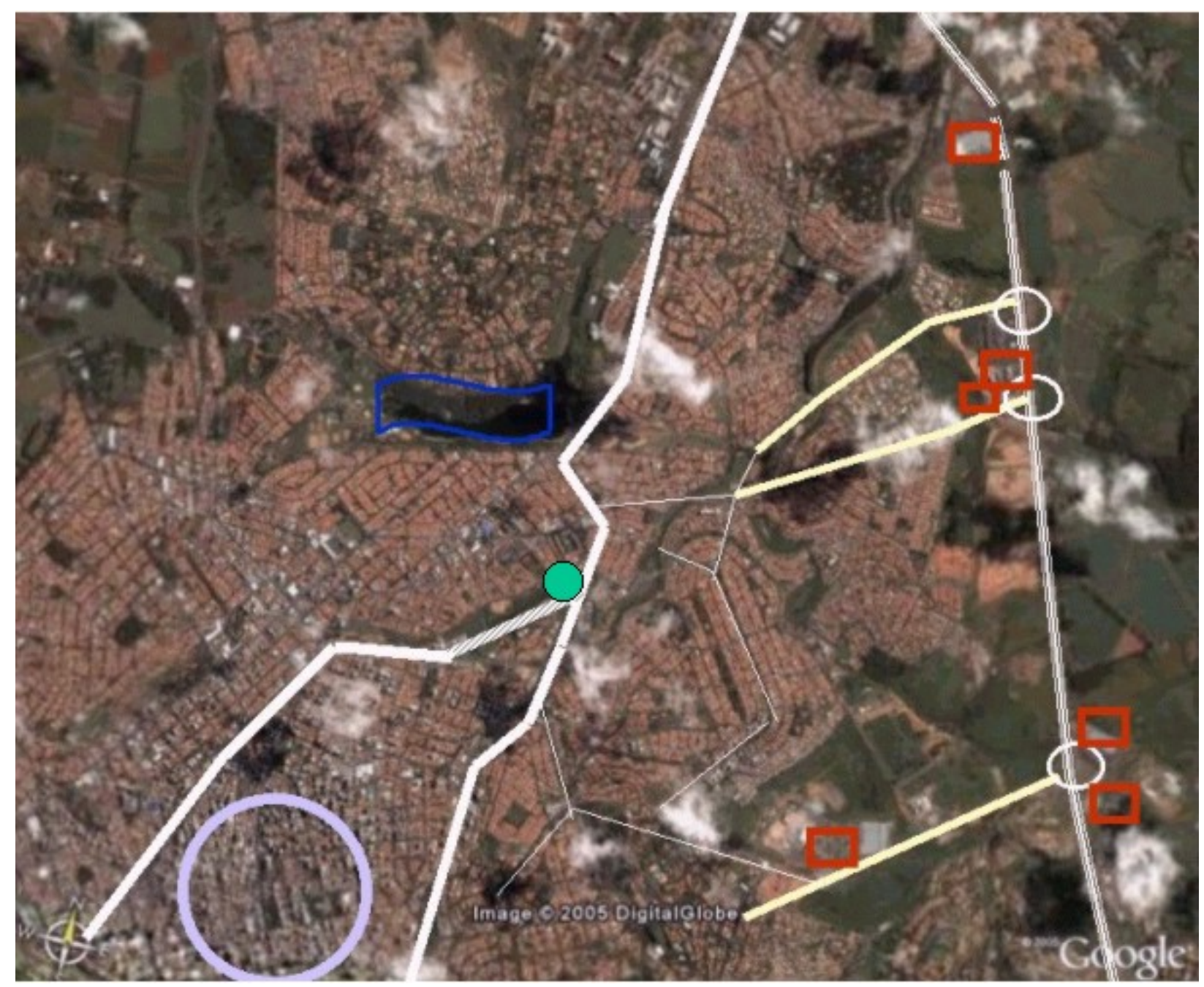

Imagem 43: Área do Projeto Urbano Anhumas (círculo verde) próximo ao entroncamento das avenidas (em branco) que contornam o centro consolidado (círculo azul). Evidencia a característica de conexão urbana entre a cidade tradicional e a malha da Dispersão Urbana, ao longo da Rod. Dom Pedro I (em branco) e seus grandes empreendimentos comerciais, empresariais e industriais de alta tecnologia (quadrados vermelhos).Parque Lagoa do Taquaral em azul. (Google Earth 2005 ditado pelo autor) 


\subsubsection{A questão Ambiental}

\section{As Águas}

Para efeito de estudo, segundo o Relatório de Pesquisa "Recuperação Ambiental, participação e poder público: uma experiência em Campinas", o curso do ribeirão Anhumas foi dividido em três momentos: alto curso, médio curso e baixo curso. Neste momento, somente as descrições do alto e médio curso se fazem necessários, por estarem inseridas na área de estudo.

$\mathrm{Na}$ rede de drenagem do alto curso, localizam-se os dois principais afluentes que formam o ribeirão Anhumas: o córrego Proença e o Canal de Saneamento (ou Serafim, ou córrego Orozimbo Maia, como é popularmente conhecido). Ambos drenam áreas centrais ou bairros próximos ao centro da cidade. Estas áreas, fruto da dinâmica ocupacional do município, possuem elementos físicos e socioeconômicos densamente urbanizados, edificados e impermeabilizados. Estes córregos, através do escoamento superficial e da rede de drenagem, recebem águas pluviais e esgoto de toda área central e bairros vizinhos.

O córrego do Proença, que tem seu curso ligado à história da fundação de Campinas, possui suas nascentes próximas ao Parque Ecológico Monsenhor Emilio José Salim, drenando à jusante os bairros de Parque Itatiaia, São Fernando, Vila Lemos, Proença, Guarani, Ponte Preta, Nova Campinas, Cambuí e outros, recebendo, assim, grande parte das águas da rede de drenagem e esgoto desses bairros.O córrego, em função da sua contribuição fluvial, é o principal formador do ribeirão Anhumas.

Apresenta algumas características urbanísticas importantes relacionadas à diferenciação no aspecto ocupacional, verificados ao longo do seu curso. Inicialmente, na Avenida Princesa D'oeste, o córrego se encontra canalizado e posteriormente revestido parcialmente, com vias expressas marginais. Após o cruzamento com a Avenida Moraes Sales, onde se inicia a Av. José de Souza Campos (Via Norte Sul), o córrego possui em seu entorno, ao longo de 300 metros aproximadamente, uma área que foi integrada à estrutura urbana como "área verde". As Praças Augusto César e Ralph Stettinger são um bom exemplo de um uso adequado frente às possibilidades de impactos do local. 
Esta política de ocupação não foi seguida à jusante, onde, ao longo da Via Norte Sul, o córrego Proença foi canalizado e aterrado em obras de saneamento. A Prefeitura, meados da década de 1990, executou as obras com objetivo de se evitar alagamentos nas margens ao longo do canal.

O Canal de Saneamento, que drena boa parte da área central da cidade, não possui características hídricas e urbanísticas muito diferentes. Seu leito se encontra revestido parcialmente. Também possui vias expressas em sua área marginal, as avenidas Anchieta e Orozimbo Maia. Em relação ao aspecto hídrico, o córrego possui uma vazão baixa, ma s a exemplo do Proença, recebe o despejo do esgoto e as águas do sistema de drenagem que, além de comprometer a qualidade hídrica do córrego, aumenta em muito sua vazão quando há ocorrências de chuvas extremas. Devido a sua menor vazão, problemas como o mau cheiro se torna mais graves.Em seu entorno observa-se pouca presença de vegetação, que deu lugar as torres de fios alta tensão da CPFL..

Em função das conseqüências sociais dos impactos, o médio curso da bacia destaca-se negativamente. Suas particularidades começam a ser notadas já no encontro dos córregos da Orozimbo e Proença, onde se forma o ribeirão Anhumas.

A Via Norte Sul tem continuidade através de dois pontilhões que passam sobre o local. A área sofre inundações, minimizadas pelo "piscinão" destinado a conter o aumento do volume e da velocidade da vazão fluvial na ocorrência de chuvas intensas. O estado de degradação se acentua à jusante, onde as áreas marginais e os fundos de vale, além de estarem sem a vegetação ciliar estão ocupados,100 evidenciando o problema habitacional e de saneamento enfrentado pelas comunidades que ocupam as margens do Anhumas.

A ocupação, com nome de Favela Guaraçai, na rua Natividade (próximo ao limite leste da área), com cerca de 531 famílias, foi objeto de reurbanização por parte da COHAB, com a construção de edifícios visando propiciar maior qualidade de vida aos moradores. ${ }^{114}$

O médio curso continua percorrendo o fundo de vale, onde há a foz do córrego Brandina, a confluência com a foz da Lagoa do Taquaral (na atual Praça

114 TORRES, R.B; Costa, M.C.; NOGUEIRA,F.P. e PEREZ Filho, A. (coord). Recuperação Ambiental, participação e poder público: uma experiência em Campinas. Relatório de Pesquisa 2006 
Arautos da Paz) e ao longo da Favela Moscou até o cruzamento com a rodovia Dom Pedro I. Neste ponto foi inaugurada em 2007 a ETE Anhumas, com capacidade de tratar esgoto correspondente a de uma população de 250 mil moradores, sendo a maior ETE de Campinas e uma das maiores do interior de São Paulo. Conseqüentemente, as cidades de Paulínia, Sumaré, Americana e Piracicaba, localizadas à jusante, serão diretamente beneficiadas, uma vez que suas águas captadas para abastecimento público deixarão de receber as cargas poluidoras dos esgotos domésticos de Campinas.

A área do Projeto Urbano Anhumas é o setor urbano onde o antigo Leito Ferroviário da Mogiana corre paralelamente ao Córrego canal de Saneamento. Este córrego posteriormente se encontra com o Córrego Proença, formando o Ribeirão Anhumas, que dá nome ao Projeto Urbano (Ver Imagens 10 e 11).

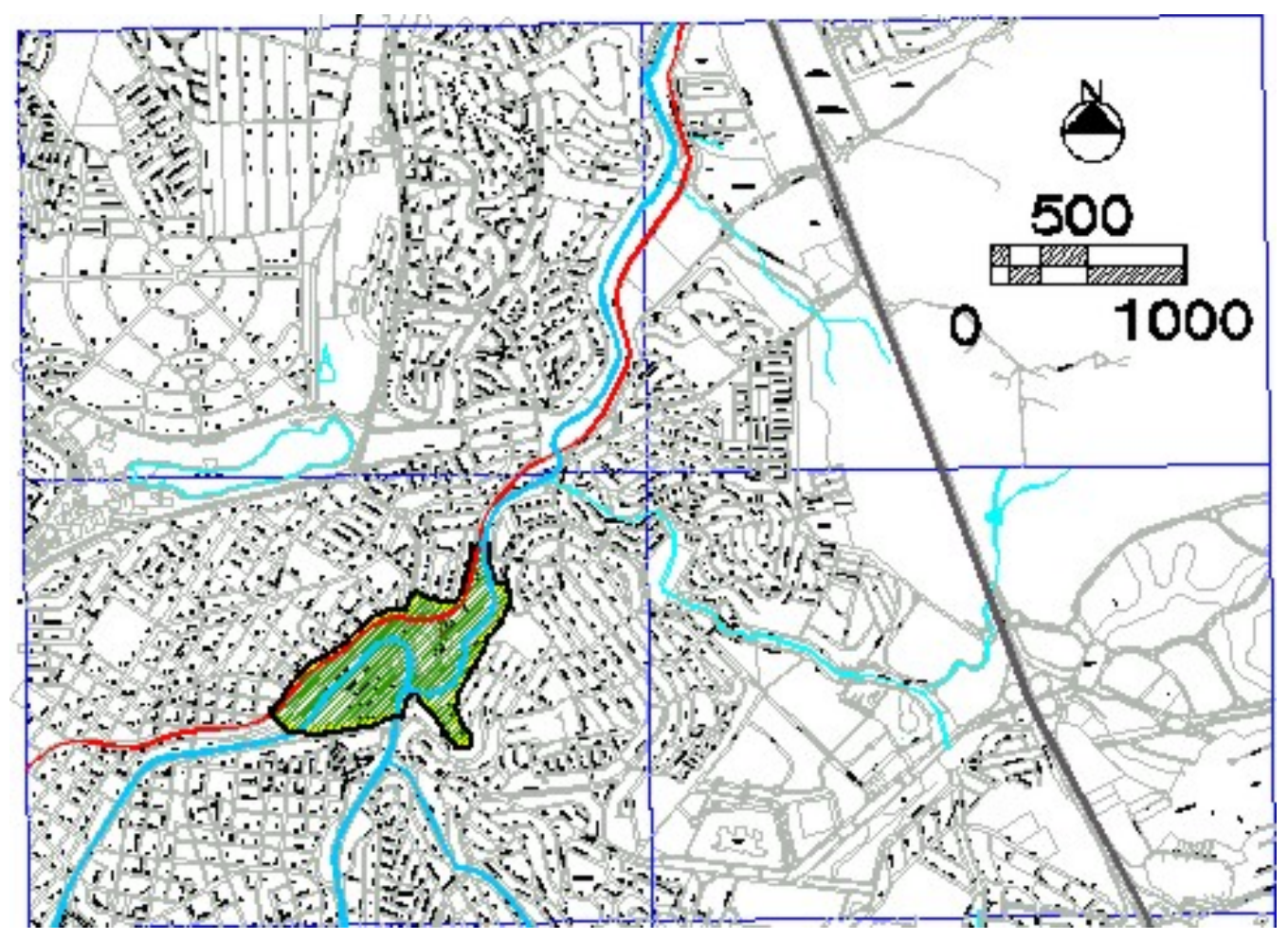

Imagem 44: Área do Projeto Urbano Anhumas (em verde), o Leito Ferroviário (em vermelho) e os córregos formadores do ribeirão Anhumas. (Seplama editado pelo autor) 


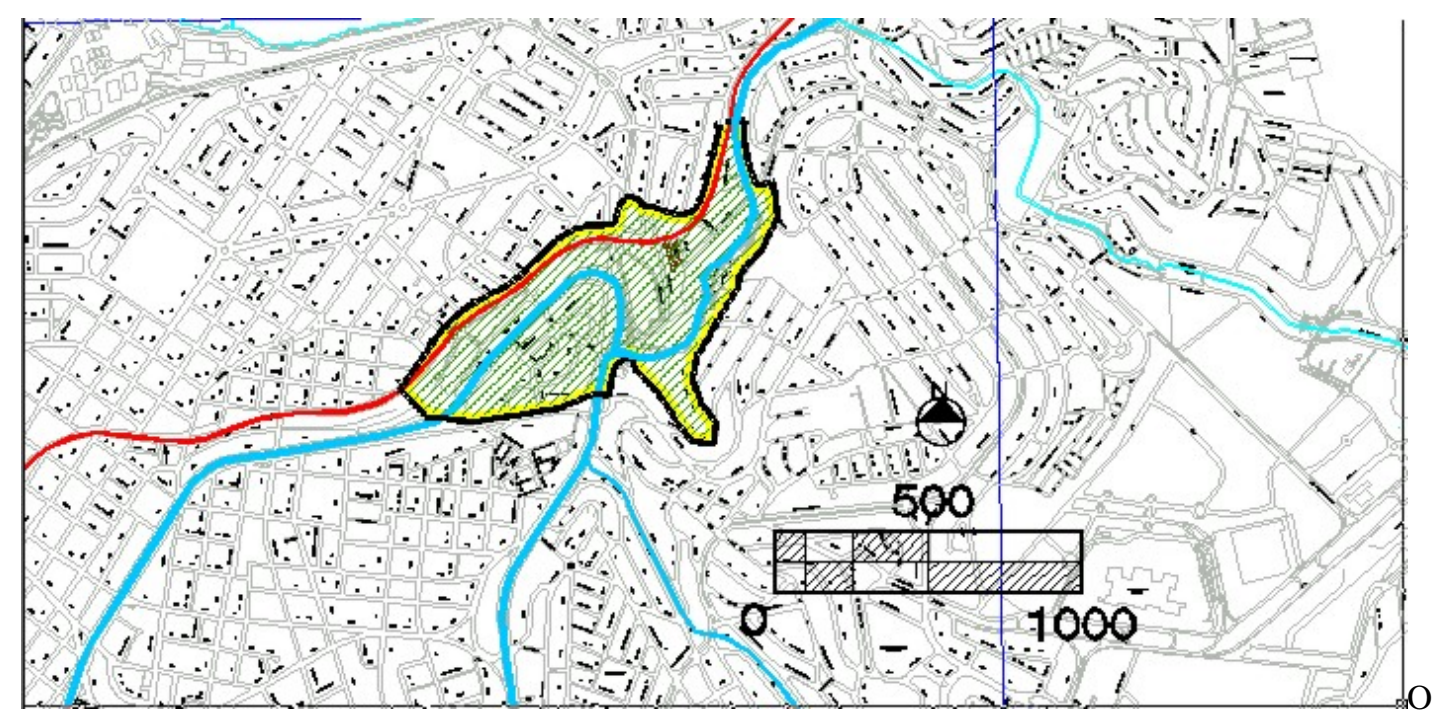

Imagem 45: Aproximação da área do Projeto Urbano Anhumas (em verde), o Leito Ferroviário (em vermelho) e os córregos formadores do ribeirão Anhumas. (Seplama editado pelo autor).

\section{Eixos Verdes}

Outro importante fator é a configuração de conexão, na escala urbana, de grande áreas livres. Situada como ponto de convergência dos córregos Oriente e Mato Dentro, que nascem na região do Parque Ecológico de Campinas (ver Imagem 12 e 13), posteriormente funcionam como "Eixo Verde" até o Parque Lagoa do Taquaral, a mais importante área de lazer pública da cidade (ver imagem 14 e 15). 


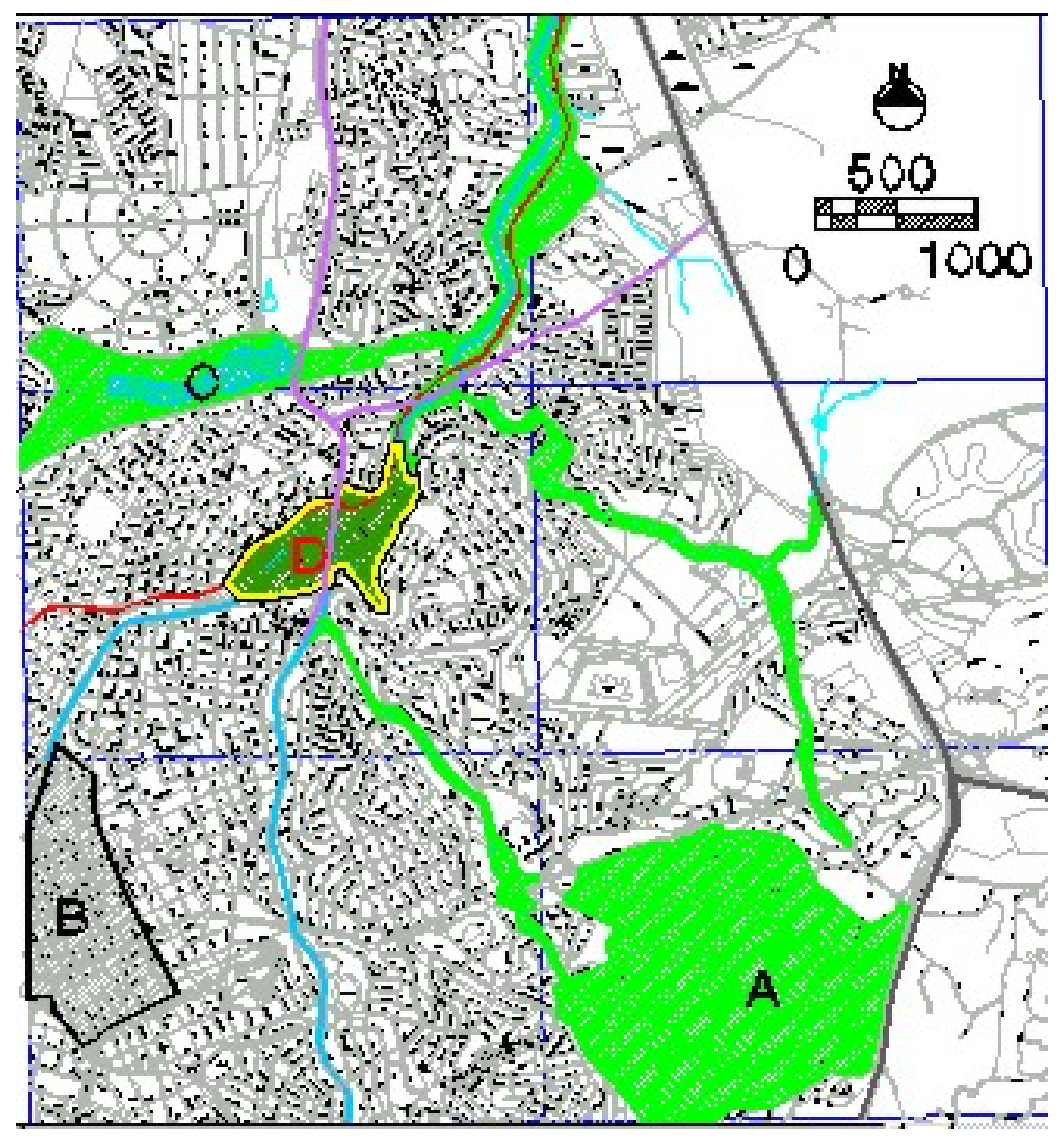

Imagem 46: "Eixos Verdes" conectando o Parque Ecológico (letra A), o Projeto Urbano Anhumas (letra D) com o Parque Lagoa do Taquaral (letra C) através dos cursos d'água dos córregos Mato Dentro, Oriente e Anhumas. Centro Verticalizado sinalizado com a letra B. (Seplama editado pelo autor)

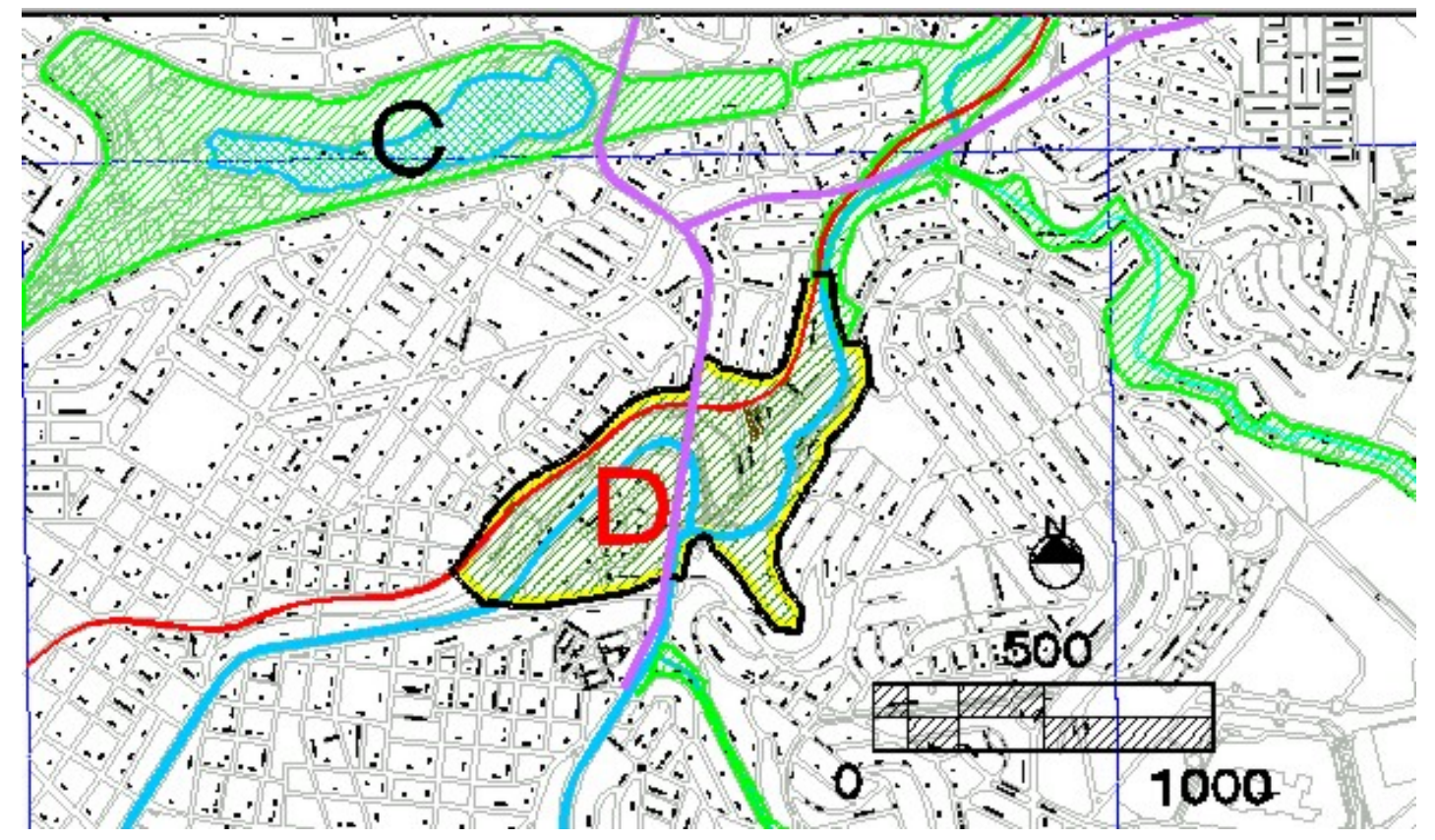

Imagem 47: "Eixos Verdes" articulados pelo Projeto Urbano Anhumas (Seplama editado pelo autor) 


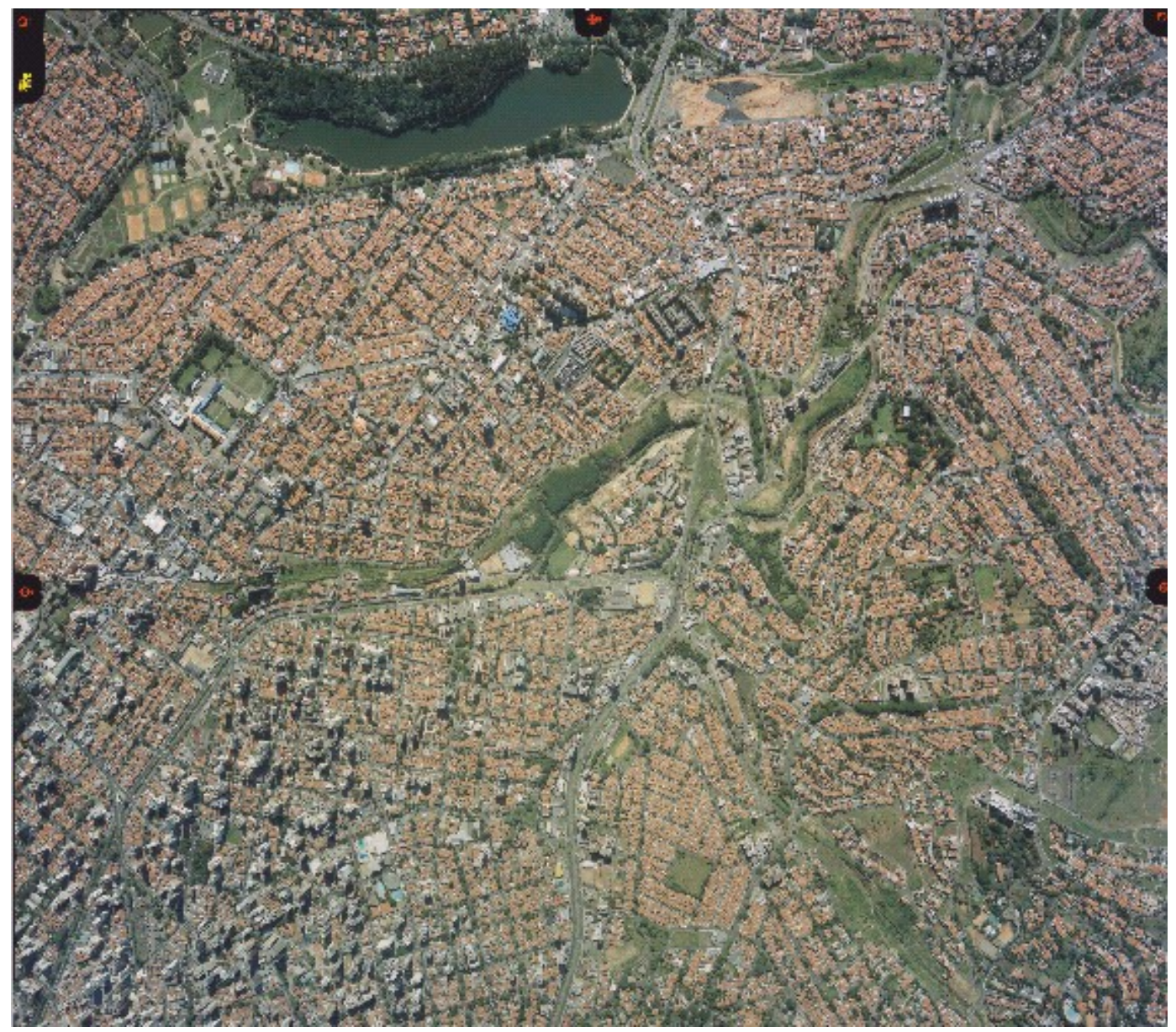

Imagem 48: "Eixos Verdes",área do Projeto Urbano Anhumas (centro da imagem), o Parque Lagoa do Taquaral ( parte superior) e a Praça Arautos da Paz. (Foto Aérea Seplama 2004)

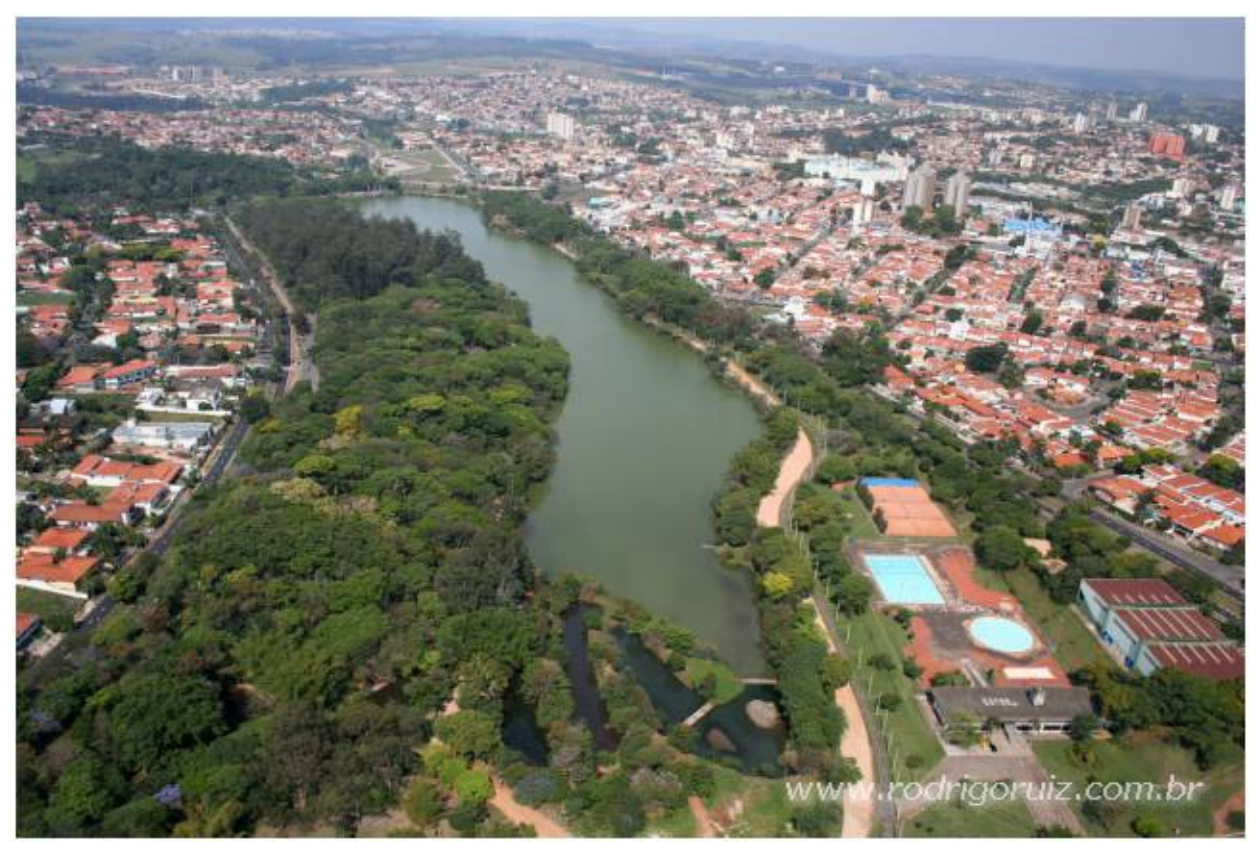

Imagem 49: Vista aérea do Parque Lagoa do Taquaral.. (www.rodrigoruiz.com.br) 


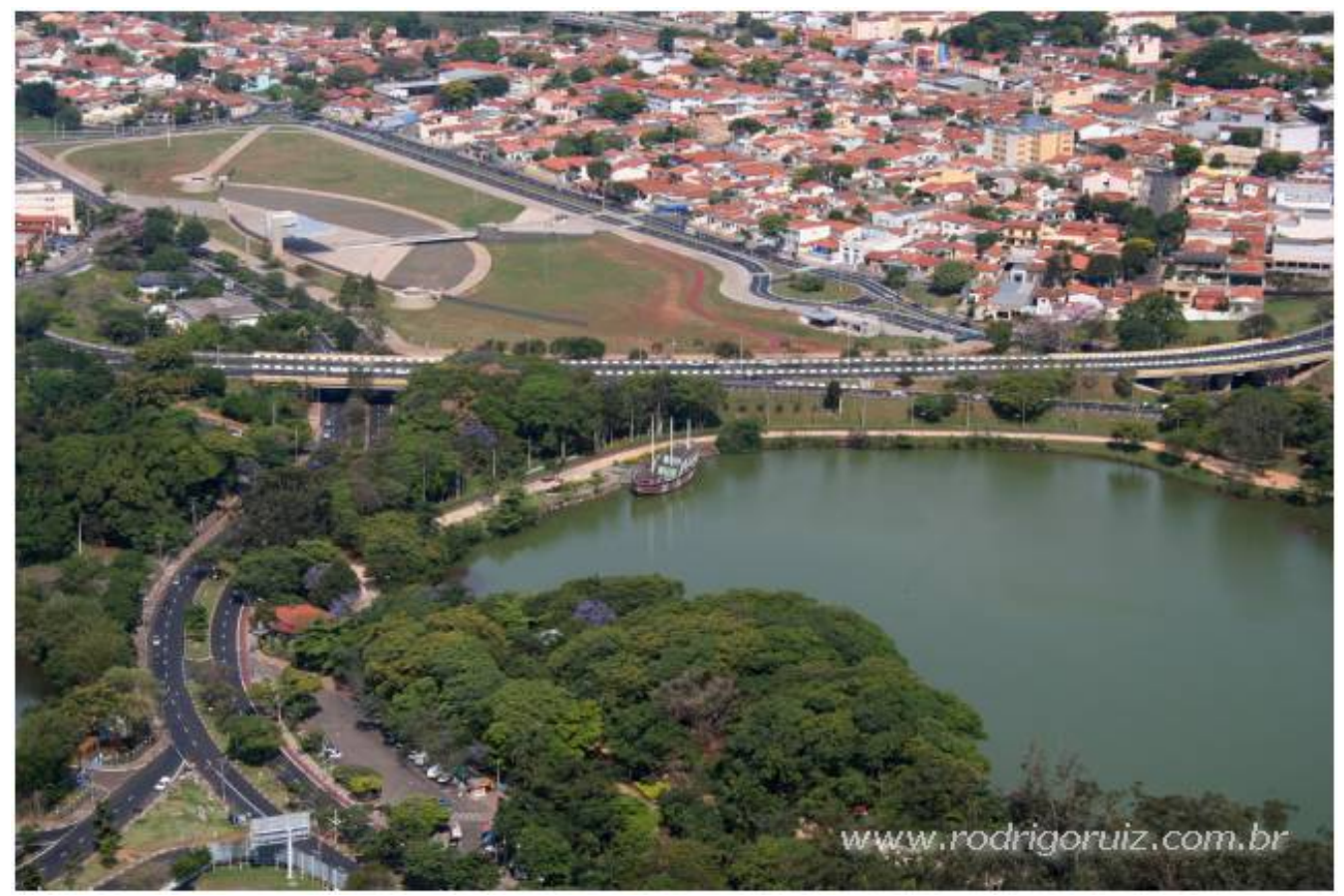

Imagem 50: Vista aérea do Parque Lagoa do Taquaral e a Praça Arautos da Paz. (www.rodrigoruiz.com.br) 


\subsubsection{A questão da Legislação}

Em relação ao zoneamento, de acordo com a Lei de Uso e Ocupação do Solo, a área de estudo apresenta restrição apenas ao uso industrial e possui uma gleba (em magenta) considerada como Zona Especial, onde é necessária avaliação de estudo específico.

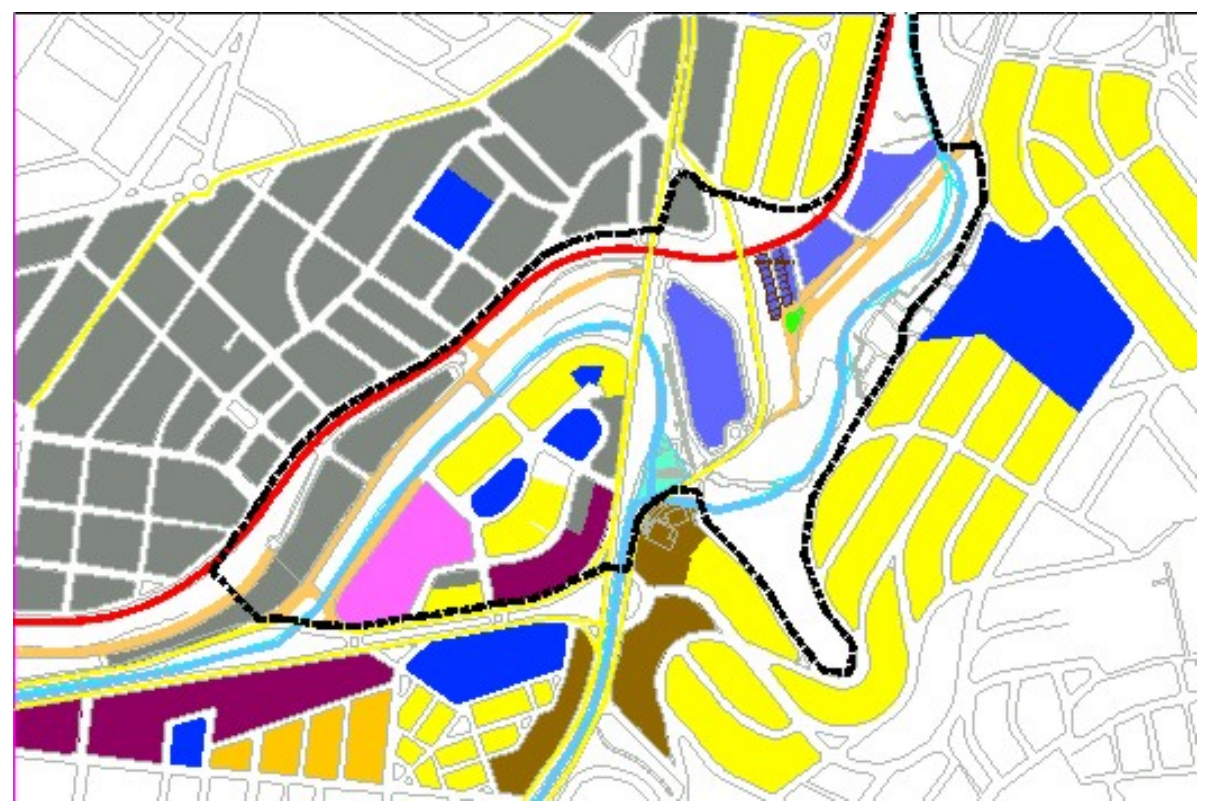

Imagem 51: Zoneamento da área e da região do Entorno do Projeto Urbano Anhumas, conforme a seguinte legenda de cores para as zonas:

Fonte: Lei de Uso e Ocupação do Solo - Prefeitura Municipal de Campinas/2001

Cinza: $\mathbf{Z 9 ~ - ~ C o m e ́ r c i o , ~ S e r v i c ̧ o s ~ e ~ I n s t i t u c i o n a l ~ - ~ H a b i t a c ̧ a ̃ o ~ u n i ~ e ~ m u l t i ~}$ familiares, horizontais e verticais;

Vinho: Z10 - Comércio, Serviços e Institucional - Habitação uni e multi familiares, horizontais e verticais;

Magenta: Z18 I Zona Especial - Áreas de Interesse somente sob avalição de estudo específico;

Azul: Z11 - Comércio, Serviços e Institucional - Habitação uni e multi familiares, horizontais e verticais;

Amarelo: Z3 - Comércio, Serviços e Institucional - Habitação uni e multi familiares, horizontais e verticais;

Laranja: Z6 - Comércio, Serviços e Institucional - Habitação uni e multi familiares, horizontais e verticais; 
Marrom: Z13 - Comércio, Serviços e Institucional - Habitação uni e multi familiares , horizontais e verticais;

O Plano Diretor de Campinas (2006) define, para a Macrozona 04, o seguinte perfil: "Área urbana por excelência, onde se faz necessária a otimização e racionalização da infra-estrutura existente, através do controle do adensamento e do incentivo à mescla de atividades, à consolidação de subcentros e à implantação de atividades geradoras de emprego fora da área central."

O Plano Diretor ainda cita as seguintes orientações estratégicas gerais para a macrozona de estudo, que podem ser diretamente aplicadas ao Projeto Urbano Anhumas:

- recuperação das áreas precariamente urbanizadas, com requalificação e estruturação urbana, buscando a articulação dos bairros existentes e criação de subcentros, sem, contudo, incentivar um adensamento contínuo da região;

- manutenção e preservação de áreas verdes, de áreas de proteção dos mananciais visando ao equilíbrio ambiental;

- permissão da expansão do centro, com intensificação de atividades e adensamento da ocupação do entorno (Castelo, Guanabara, Taquaral), com controle adequado;

- abertura de novas possibilidades de adensamento e de localização de atividades geradoras de emprego em locais potencializados pelos investimentos públicos, notadamente em viário e transportes

- $\quad$ estruturação do sistema viário e de transportes, considerando também as intervenções previstas (Veículo Leve sobre Trilhos - VLT, Trem Intrametropolitano - TIM, novo terminal rodoviário intermunicipal, complementação do anel viário), de maneira a diminuir os fluxos de passagem pelo centro.

Dentre as diretrizes específicas para a Macrozona 04 propõe: 
“(...)Controlar a expansão e a ocupação urbana, buscando equilibrar a distribuição das atividades e otimizar a infra-estrutura instalada através de:

- critérios específicos para ocupação dos diferentes setores identificados com base na capacidade da infra-estrutura instalada e projetada;

priorização dos investimentos públicos para as áreas ocupadas e com carência de infra-estrutura;

abertura de novas possibilidades de adensamento e de localização de atividades geradoras de emprego em locais potencializados pelos investimentos públicos, notadamente em viário, transporte e drenagem;

estruturação do sistema viário e de transportes, promovendo a interligação entre bairros através de obras de complementação viária, de correções geométricas e alterações operacionais;

- implantar sistema viário interbairros de forma a integrar a configuração do sistema viário atual promovendo a interligação entre os subcentros existentes e propostos, através de obras de complementação viária, correções geométricas e alterações operacionais, com vistas a incrementar a não-viagem, democratizar o acesso aos serviços e otimizar a circulação inter-setorial ;

dar continuidade ao sistema VLT, integrando-o aos demais sistemas de transporte;

- correção dos problemas críticos de drenagem, especialmente no ribeirão Anhumas, desde suas nascentes até a passagem sob a rodovia D. Pedro I,

manter as condições atuais das áreas não parceladas encravadas na mancha urbana, de forma a contribuir para 0 equilíbrio ambiental de Campinas e da região"115.

\section{Potencial da área de Estudo}

Em relação às características gerais da área como um todo, a área do Projeto urbano Anhumas apresenta inúmeras potencialidades, entre as quais destacam-se: 
- $\quad$ Requalificação do entorno urbano imediato;

- $\quad$ Integração de áreas da cidade hoje descontinuadas;

- $\quad$ Requalificação Ambiental da área ao longo do cursos d’água;

- $\quad$ Articulação de espaços verdes livres na escala da cidade;

- $\quad$ Articulação de sistemas de transportes intermodal;

- $\quad$ Percusos urbanos que valorizem o pedestre;

- $\quad$ Requalificação da Paisagem Urbana;

${ }^{115}$ CAMPINAS, Plano Diretor. Secretaria Municipal de Planejamento, Desenvolvimento Urbanos e Meio Ambiente. 2006 


\subsection{Ocupação Atual}

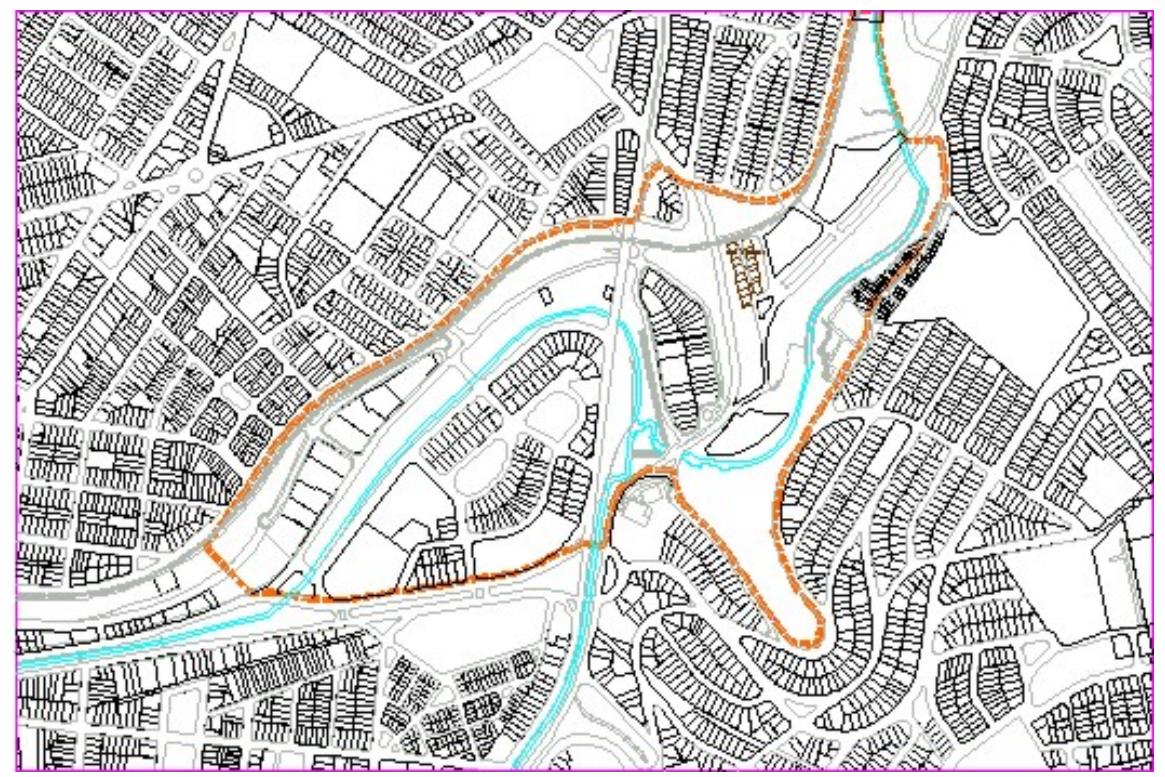

Imagem 52: Perímetro do Projeto Urbano Anhumas.(Seplama editado pelo autor)

O "Projeto Urbano Anhumas" ocupa uma área de aproximadamente 49 hectares (485.564 $\left.\mathrm{m}^{2}\right)$.

\subsubsection{Leitura da Área}

Em um primeiro momento, a área de estudo foi analisada sob os seguintes aspectos, conforme ilustrações abaixo: sistema viário, superfície dos corpos d'água, área verde, área loteada à transformar, área de construção irregular e área loteada consolidada. Para análise mais clara, entretanto, os itens acima foram agrupados sob dois aspectos: "área livre" e "área ocupada", subdividida em "consolidada" e "à transformar".

Da área total, cerca de 45\% configuram-se como área livre, enquanto que cerca de 55\% são de área ocupada, dos quais 18\% são de área à transformar e $82 \%$ são de área consolidada.

Confirmou-se portanto a percepção inicial de que a grande área livre deve exercer papel fundamental na nova organização do território. Em relação a área ocupada, 18\% sofrerá impactos diretos da intervenção. Os $82 \%$ restantes serão analisados de forma qualitativa de modo a se definir as a serem requalificadas e as áreas a serem mantidas. Este aprofundamento foi efetuado em visitas ao local. 

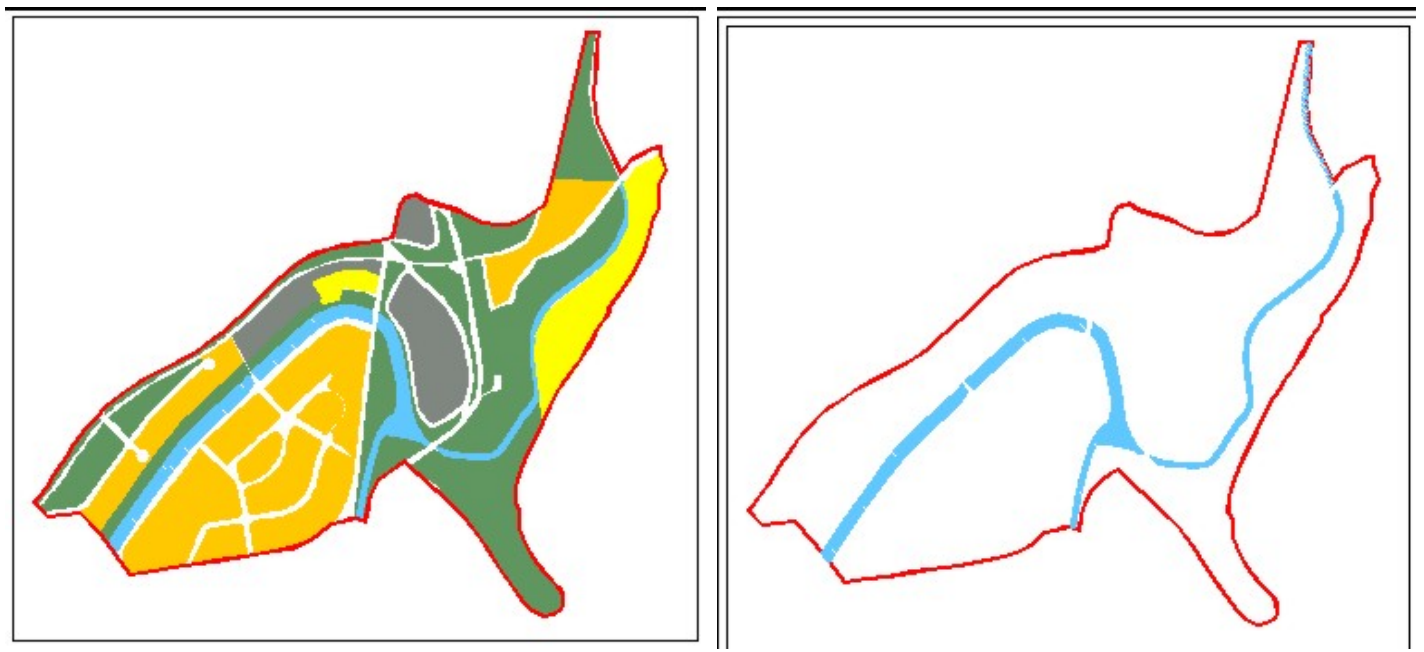

Imagem 53 e 54: Infográfico do Perímetro do Projeto Urbano Anhumas e suas subáreas (esq) e em destaque o item "Água" (dir).
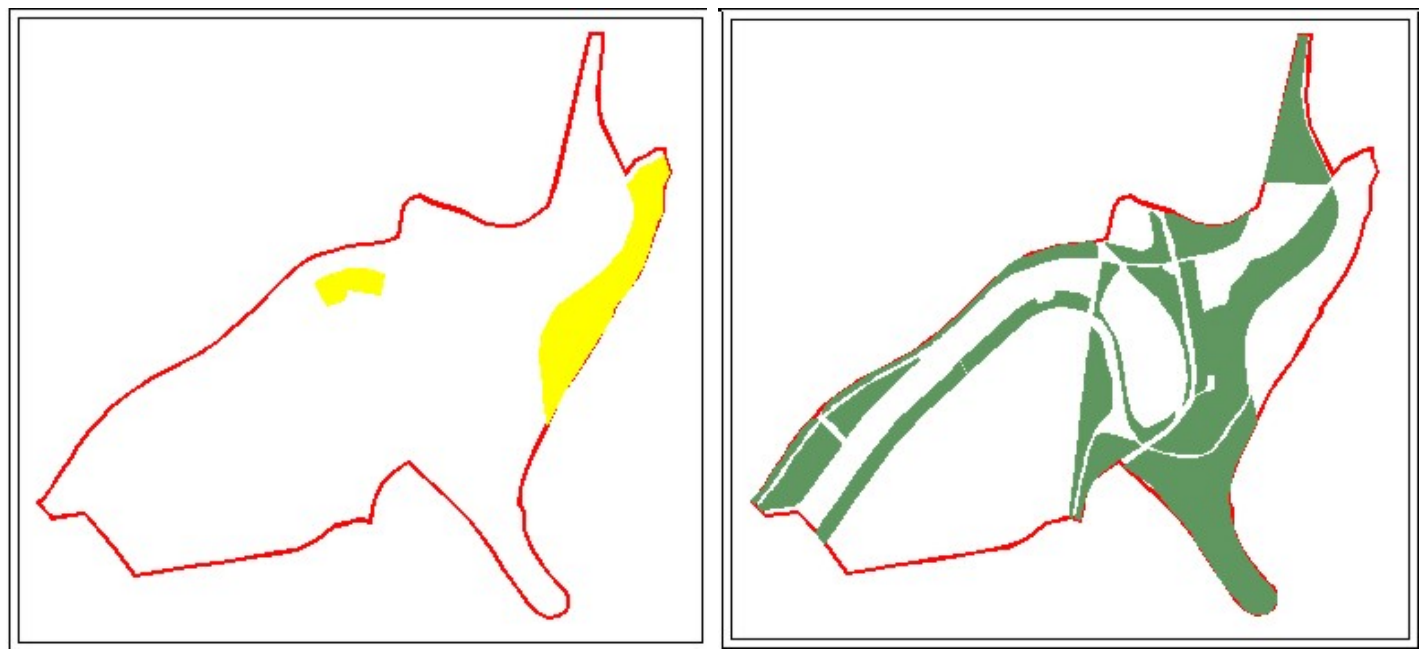

Imagem 55 e 56: "Construção Irregular " e "Verde".
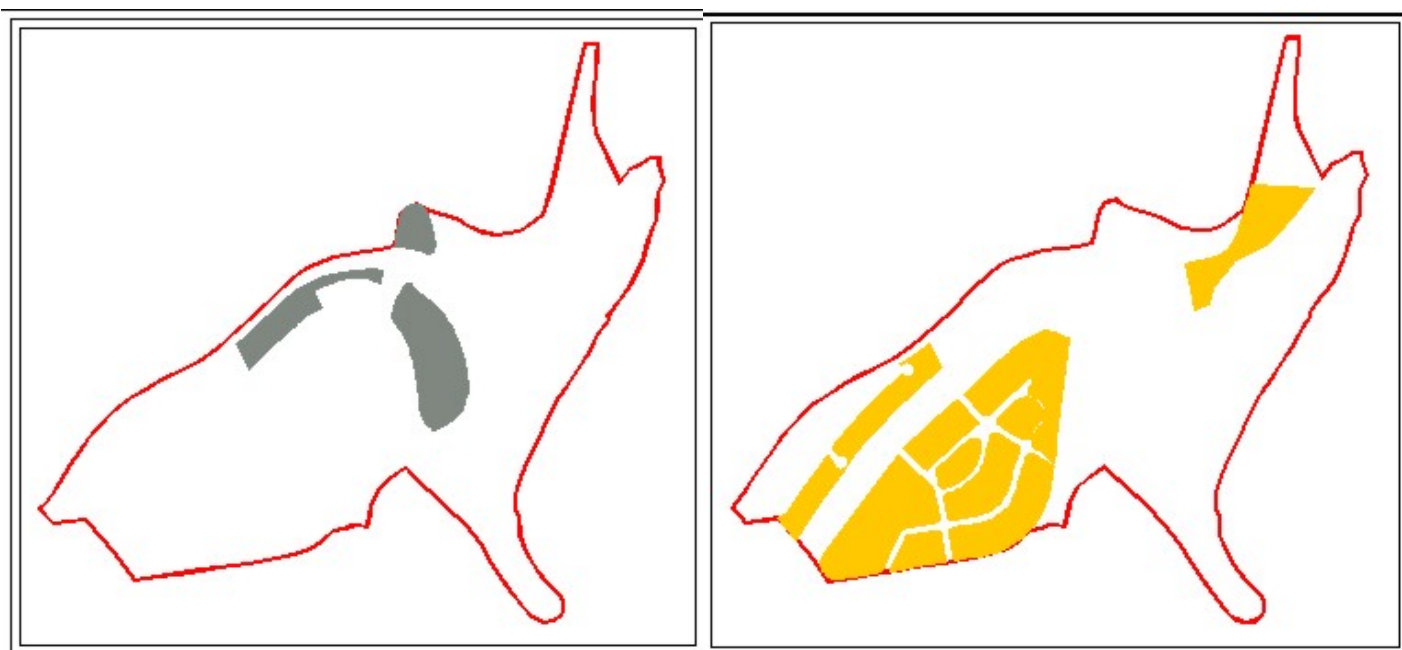

Imagem 57 e 58: "Transformar" e "Consolidada" 


\section{Setorização}

Com o aprofundamento da análise da área, foi percebida a continuidade espacial da área verde, ao longo das margens do ribeirão. A constatação de que a configuração espacial da área se dava ao longo de eixos lineares, como o da ferrovia e do ribeirão, foi logo contraposta devido à presença marcante dos viadutos. Este complexo viário, com duas alças distintas, interrompe a linearidade dos elementos, pois se torna barreira física quando está elevado sobre aterro. Estes aterros definem a llha urbana, isolada no centro da área de estudo. Com base nesta constatação, a análise de estudo passa a ser por segmentos, o que implica, necessariamente, quando da proposta, em buscar soluções de integração entre eles.

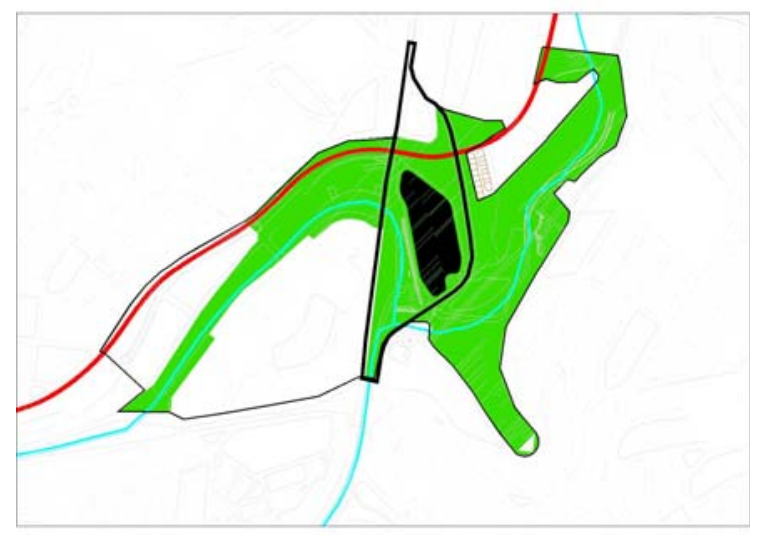

Imagem 59: Área de estudo e a continuidade espacial interrompida

A área de estudo foi segmentada em três setores, configurados em Setor A, Setor B e Setor C.(Ver imagem 60)

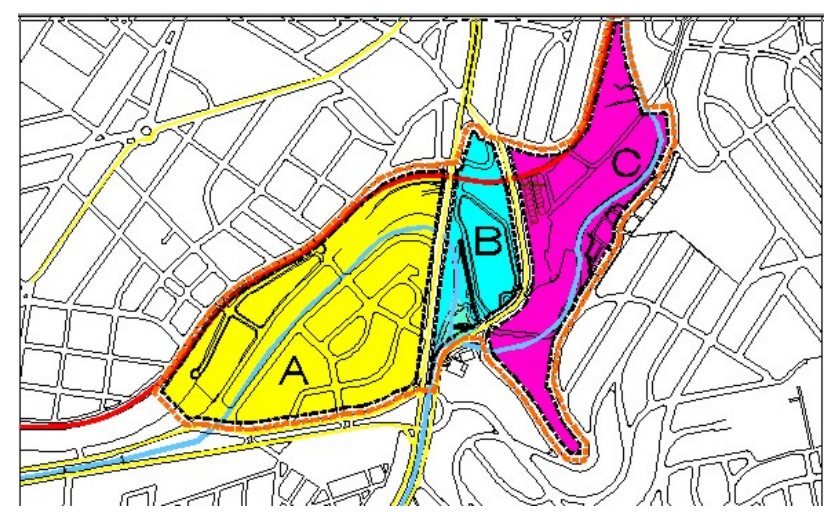

Imagem 60: Setorização da área de estudo - Setores A, B e C. 


\section{Setor A}

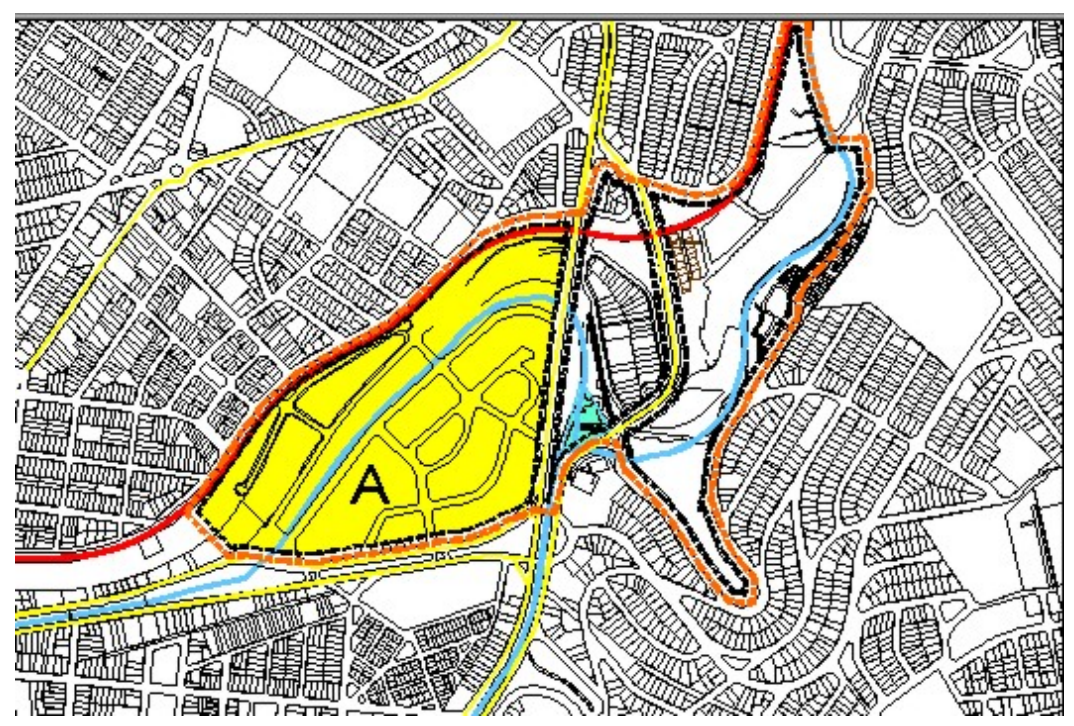

Imagem 61: Setor A, o Leito Ferroviário (em vermelho) e o Canal de Saneamento (em azul).Avenida Paula Bueno ao Norte e Av. Orozimbo Maia, ao sul (ambas em amarelo).

O Setor A apresenta área de 23 ha e está situado na parcela oeste da gleba. É seccionado por duas barreiras de integração ao tecido urbano local: o poluído ribeirão Tanquinho e o desativado Leito Ferroviário.

Este grande vazio urbano possui, em suas margens, bairros consolidados sendo:

- Bairro Taquaral - nas imediações da R. Paula Bueno - ao Norte

Situado na face suleste da encosta de uma colina (ver imagem 27), o bairro foi consolidado ao longo da Av. Paula Bueno ( ponto mais de maior altitude na topografia local), com fluxo intenso de circulação de automóveis, pedestres e transporte público.

Caracteriza-se pelo predominante uso residencial, com comércio e serviços distribuídos majoritariamente ao longo da avenida Paula Bueno.

A urbanização do bairro ocorreu entre os anos de 1945 e 1955, consolidando o tecido urbano que hoje congrega habitações unifamiliares isoladas no lote, com recuo e afastamentos (ver imagem 30).

Apresenta grande potencial ambiental e paisagístico a ser explorado, através de conexão da malha urbana com o antigo leito ferroviário que, no futuro, será mais um elemento de ligação entre bairros, com a implantação do VLT (Veiculo Leve sobre Trilhos) (ver imagem 28). 
Apresenta também, potencial de percursos qualificados para pedestres assim como de desenvolvimento urbano qualificado gerando valorização imobiliária.
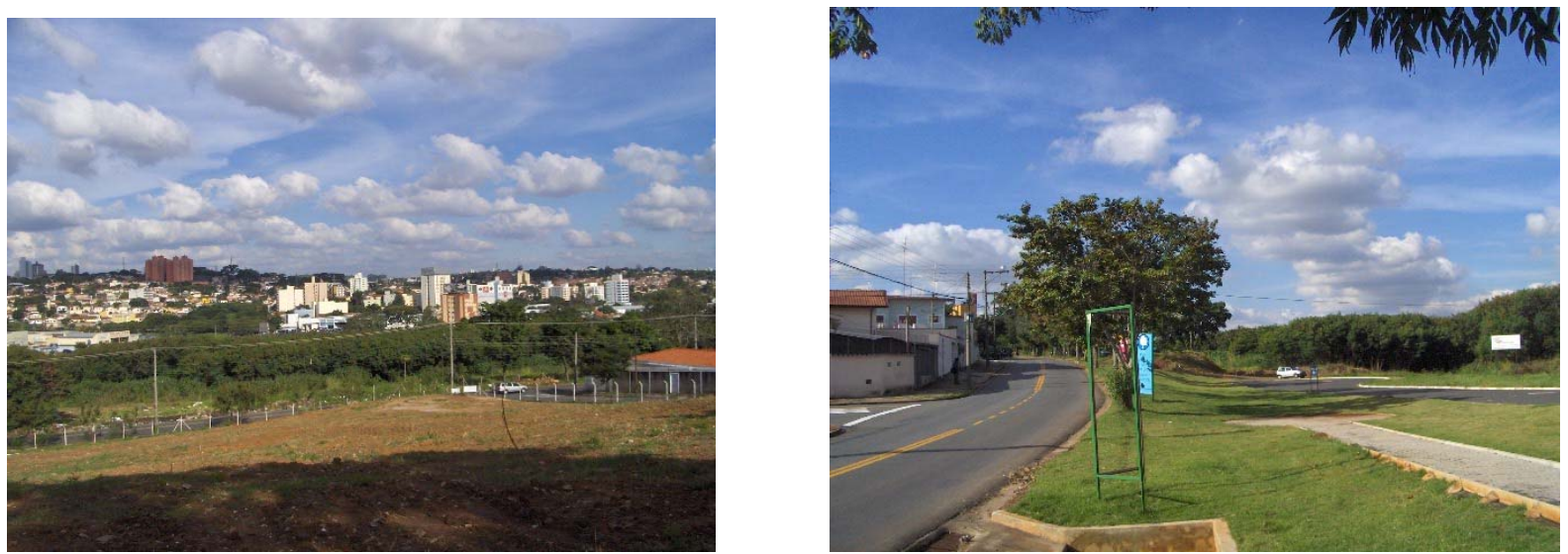

Imagem 62 e 63: Pormenores do Setor A: à esquerda, Área do Projeto Urbano Anhumas vista do Bairro Paula Bueno. À direita, avenida que separa o bairro consolidado do antigo leito ferroviário e das margens do ribeirão Tanquinho.
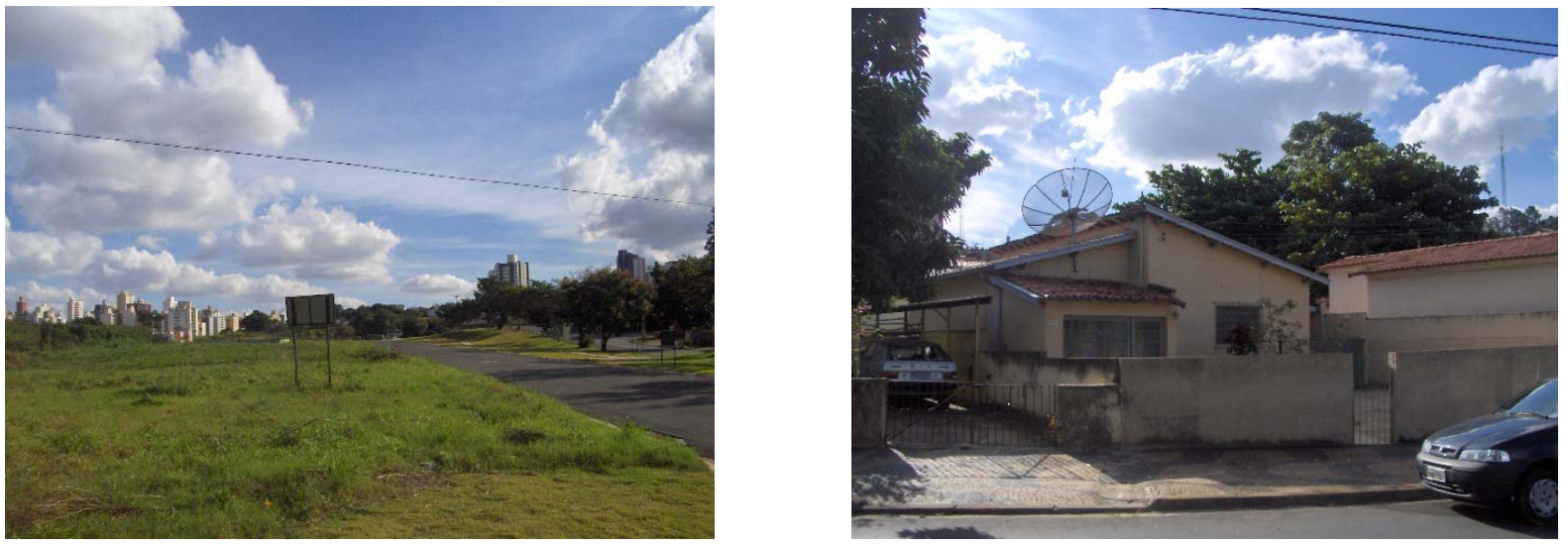

Imagem 64 e 65: Pormenores do Setor A: à esquerda, Vazio Urbano ao longo do antigo leito ferroviário. Á direita, tipologia habitacional do bairro Paula Bueno.

- Área das imediações da Igreja Menino Jesus de Praga, ao Sul:

Configurada como "ilha urbana", pois se encontra entre duas barreiras urbanas: a várzea abandonada do ribeirão e a descontinuidade viária, seccionada pela Avenida Orozimbo Maia.

Configura-se com caráter residencial e institucional, apresentando uma escola pública, uma igreja e duas creches. Nas bordas que se relacionam com a Av. Orozimbo Maia, apresenta pontos comerciais. 
Apresenta também, duas grandes áreas sub-aproveitadas, com zoneamento Z18 - Zona Especial:

01) Área da SANASA - funciona como estoque e pátio de manobra e de carga/descarga de inúmeros materiais de obra;

02) Área do Clube Cambuí - Escolinha de futebol improvisada nas margens do ribeirão Anhumas.

A acessibilidade é qualificada pela Av. Orozimbo Maia e pela proximidade da Av. Norte Sul.

A proximidade do bairro Cambuí torna a região alvo de grande interesse imobiliário, pois se apresenta com o custo da terra mais baixo do que os valores do entorno.

Apresenta grande potencial paisagístico a ser explorado, caso a conexão da várzea do Canal de Saneamento com a malha urbana, seja configurada para percursos de pedestres.

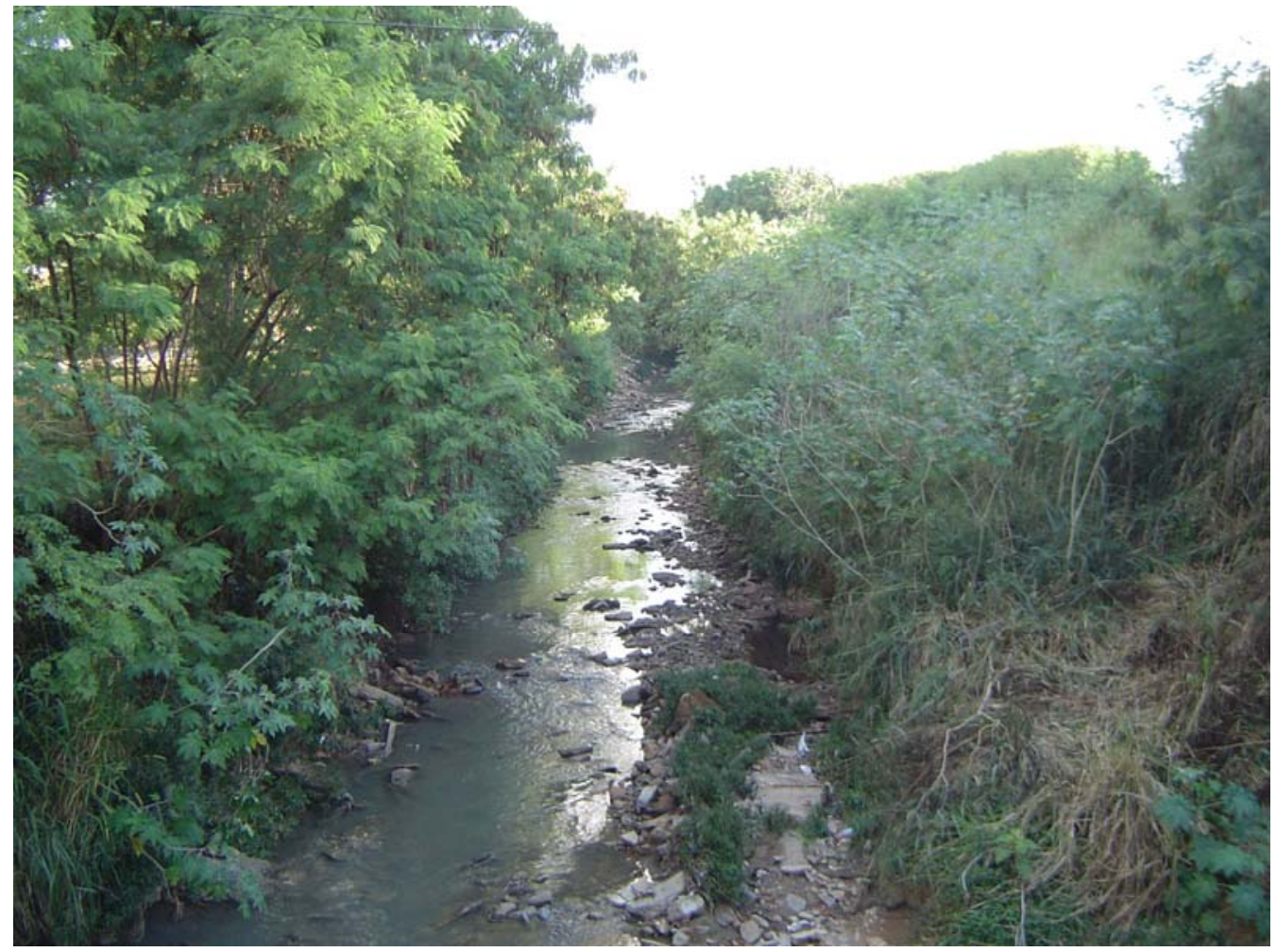

Imagem 66: Pormenores do Setor A: Córrego Tanquinho visto da ponte de pedestres. 


\section{Setor B}

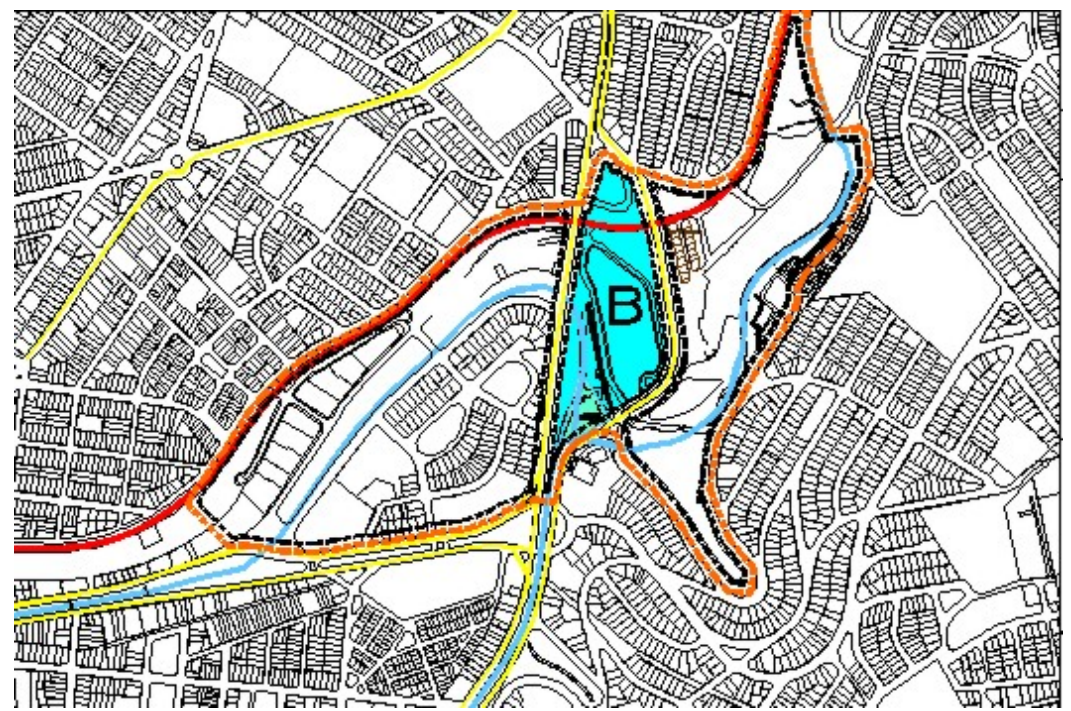

Imagem 67: Setor B,entre as duas alças dos pontilhões viários e na confluência do canal do Saneamento e o córrego Proença, formando o ribeirão Anhumas.

O Setor B possui área de cerca de 9,15 ha e é configurado como "ilha urbana" pois se encontra entre as duas alças viárias que conformam barreiras visuais e urbanas (ver imagens 33 a 38 e 40).
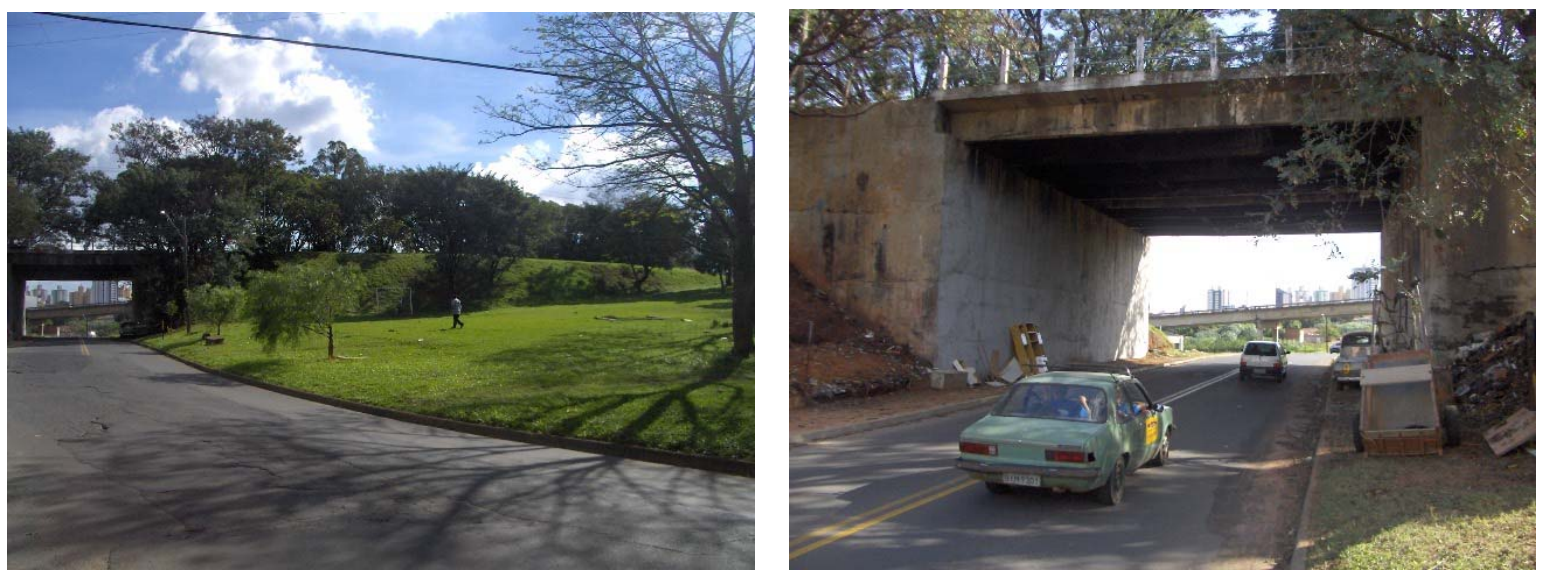

Imagem 68 e 69: Pormenores Setor B: Vistas da área e dos viadutos e seus impactos 

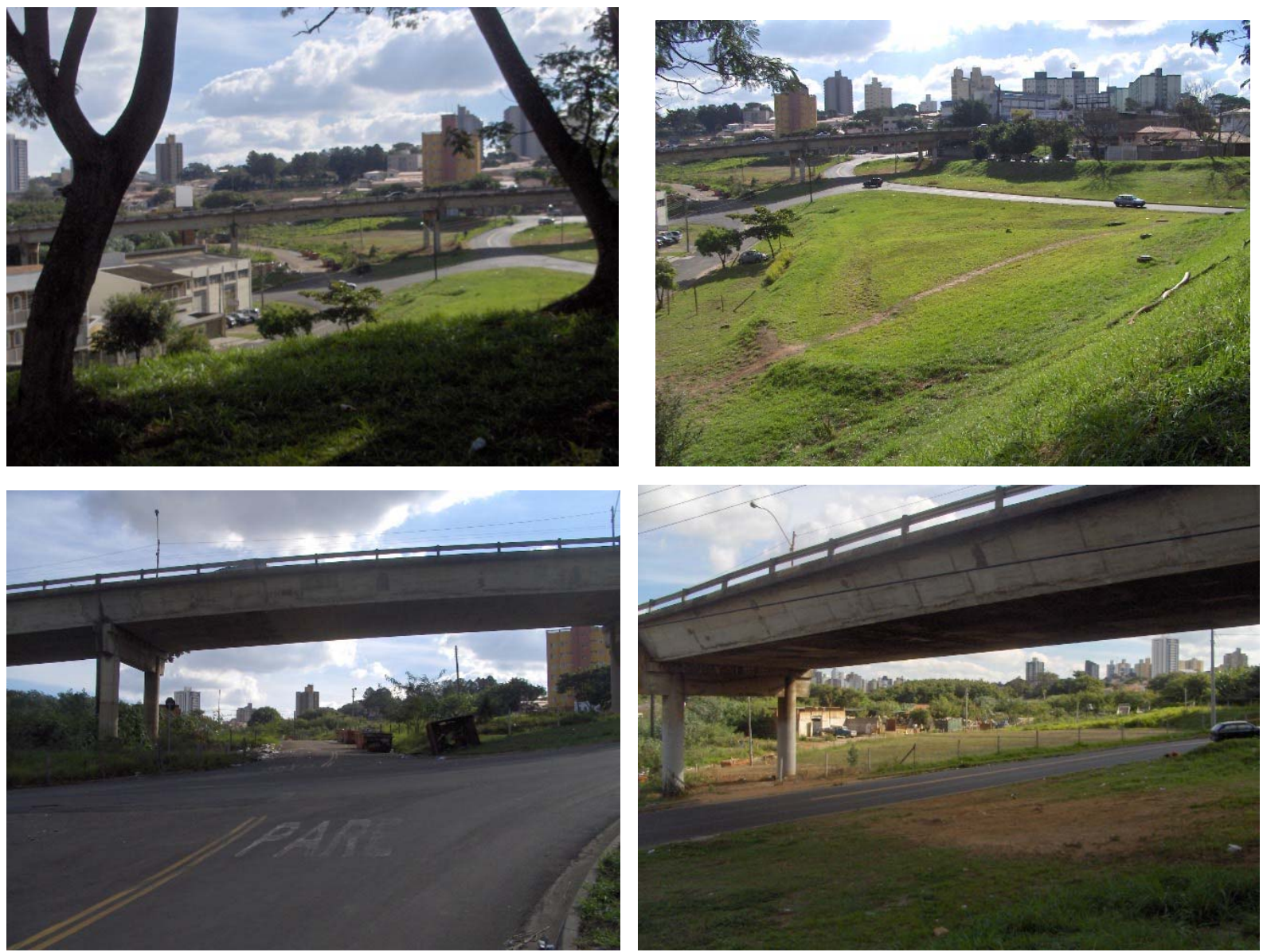

Imagem 70 a 71: Pormenores Setor B: Vistas da área e dos viadutos e seus impactos

Outro fator que dá característica ao local é o "Piscinão", para melhoria na vazão em caso de enchente, formado na confluência dos córregos Proença e Canal de Saneamento, formando o ribeirão Anhumas.
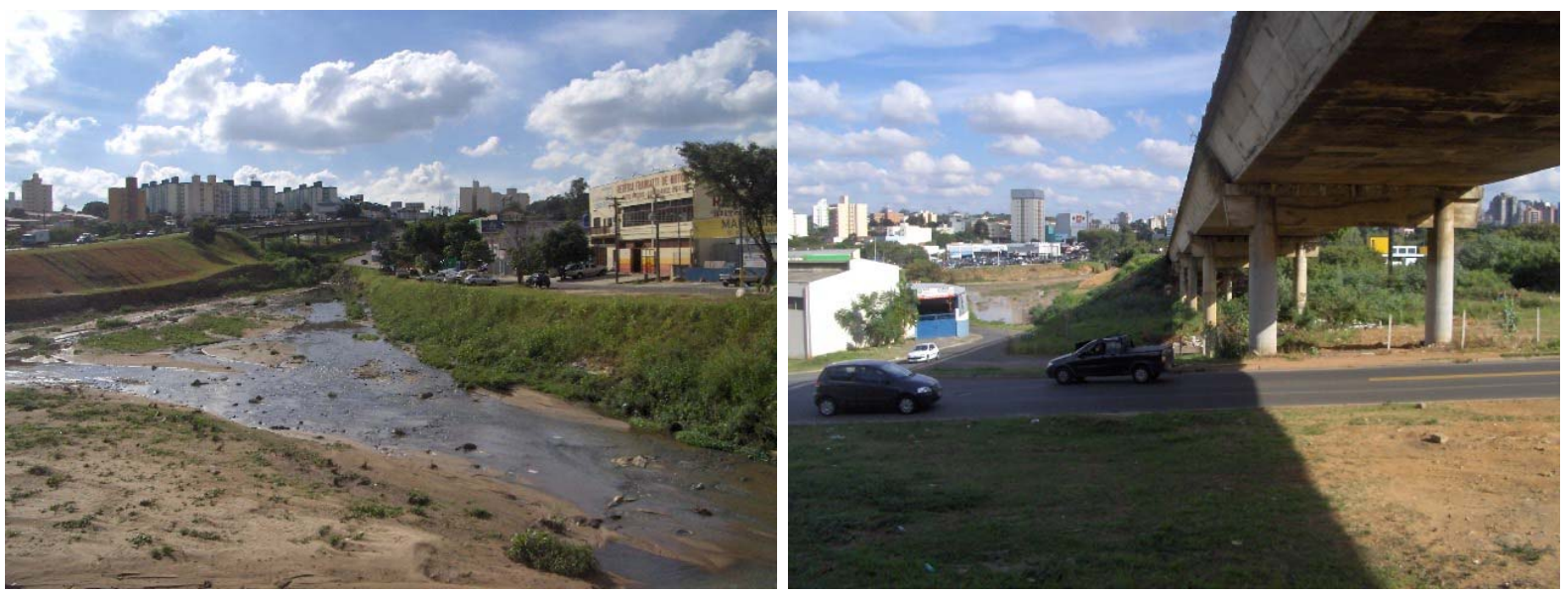

Imagem 72 e 73: Pormenor Setor B: "Piscinão" da confluência dos córregos e vista da área embaixo do viaduto, com "Piscinão" ao fundo. 
Em termos de uso, a área encontra-se sub-utilizada. Encontra-se no final da Avenida Norte Sul, importante pólo de negócios em Campinas porém pela degradação do local, instalaram-se apenas empresas de pequeno porte, tais como: Funilaria e Pintura, Auto Elétricas, Serralherias e Distribuidoras de Gás.

Embora "ilhado" entre dois pontilhões viários que formam verdadeiras barreiras urbanas - no caso do pontilhão apoiado em taludes, cria-se uma barreira física e no outro pontilhão, o impacto maior é o visual, aliado á descontinuidade das vias embaixo do viaduto - este conjunto de lotes tem potencial de grande valorização imobiliária, em caso de requalificação urbana e ambiental da área.
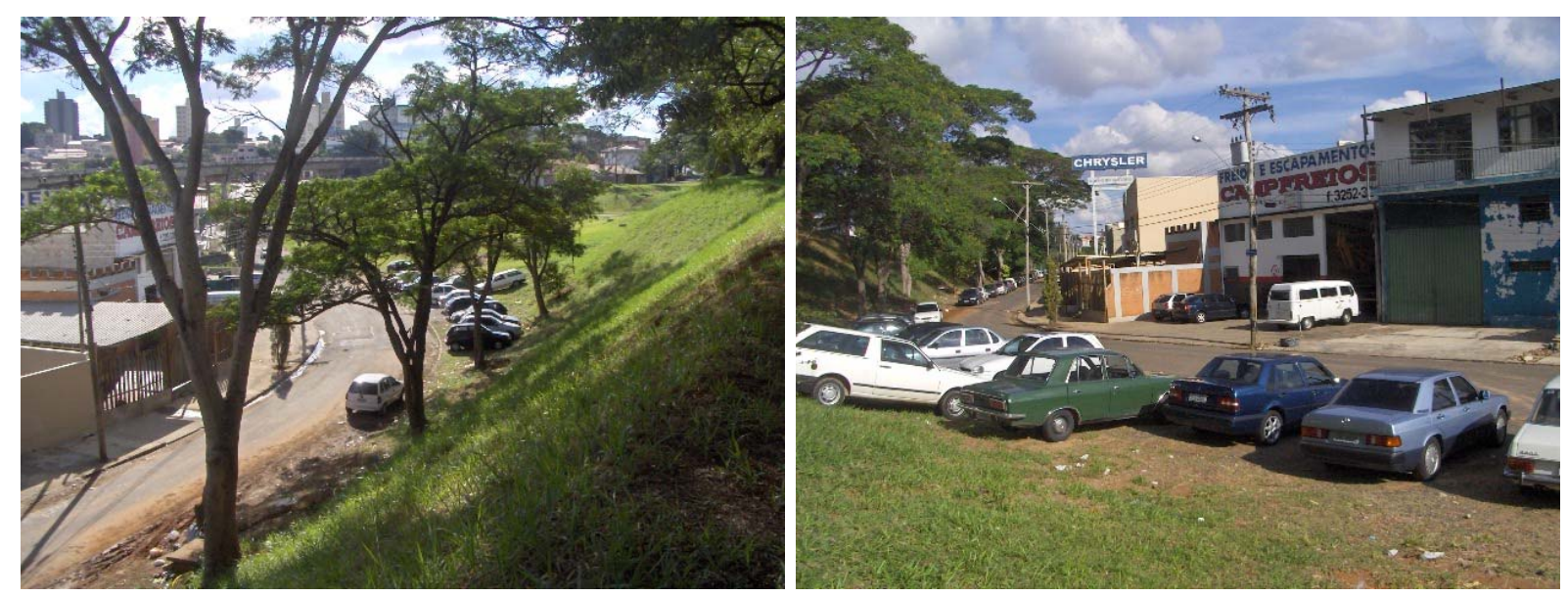

Imagem 41 e 42: Pormenores Setor B: Situação urbana entre barreiras e uso do solo por empresas de pequeno porte.
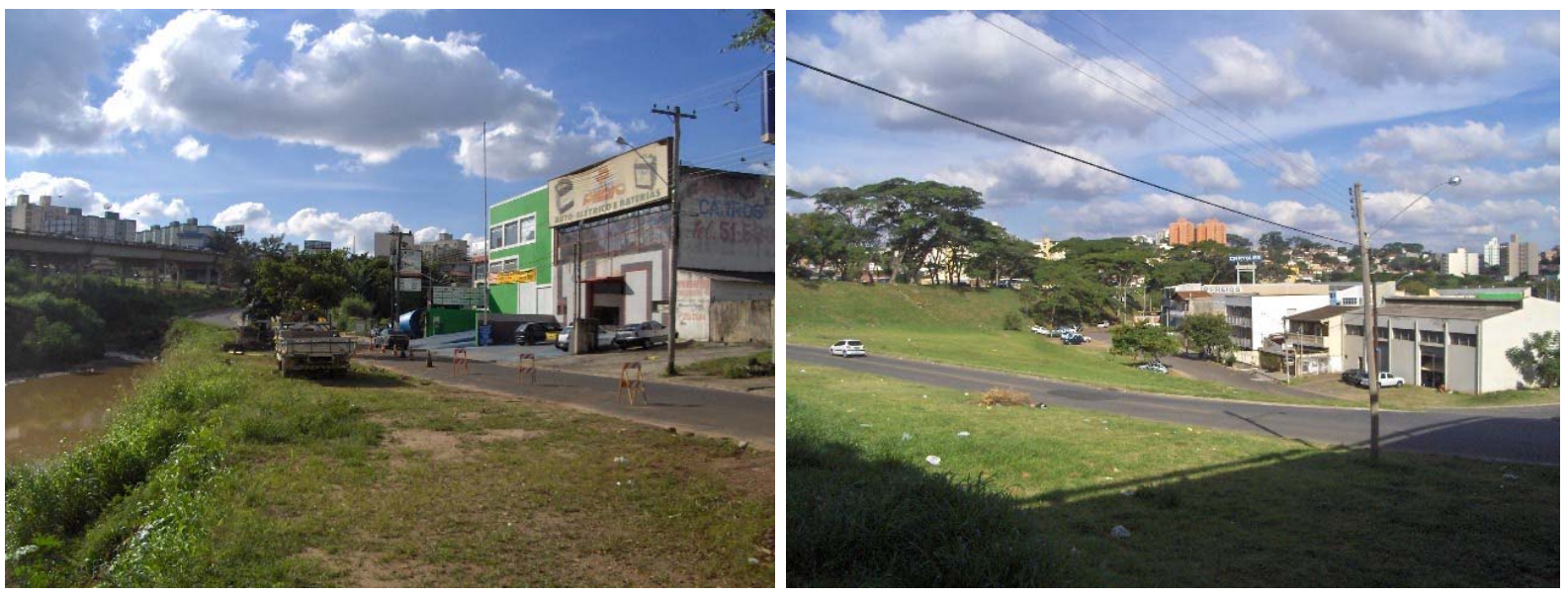

Imagem 43 e 44: Pormenores Setor B: Situação urbana entre barreiras e uso do solo por empresas de pequeno porte. 
O Setor B apresenta ainda uma grande área livre de construções, situada estrategicamente de forma paralela ao viaduto e perpendicularmente ao Leito Ferroviário. A configuração desta área é propícia para instalação de Terminal Intermodal. Esta estação deverá integrar o tecido urbano da região, pois deverá tirar partido dos desníveis existentes na gleba (ver imagens 45 e 46).
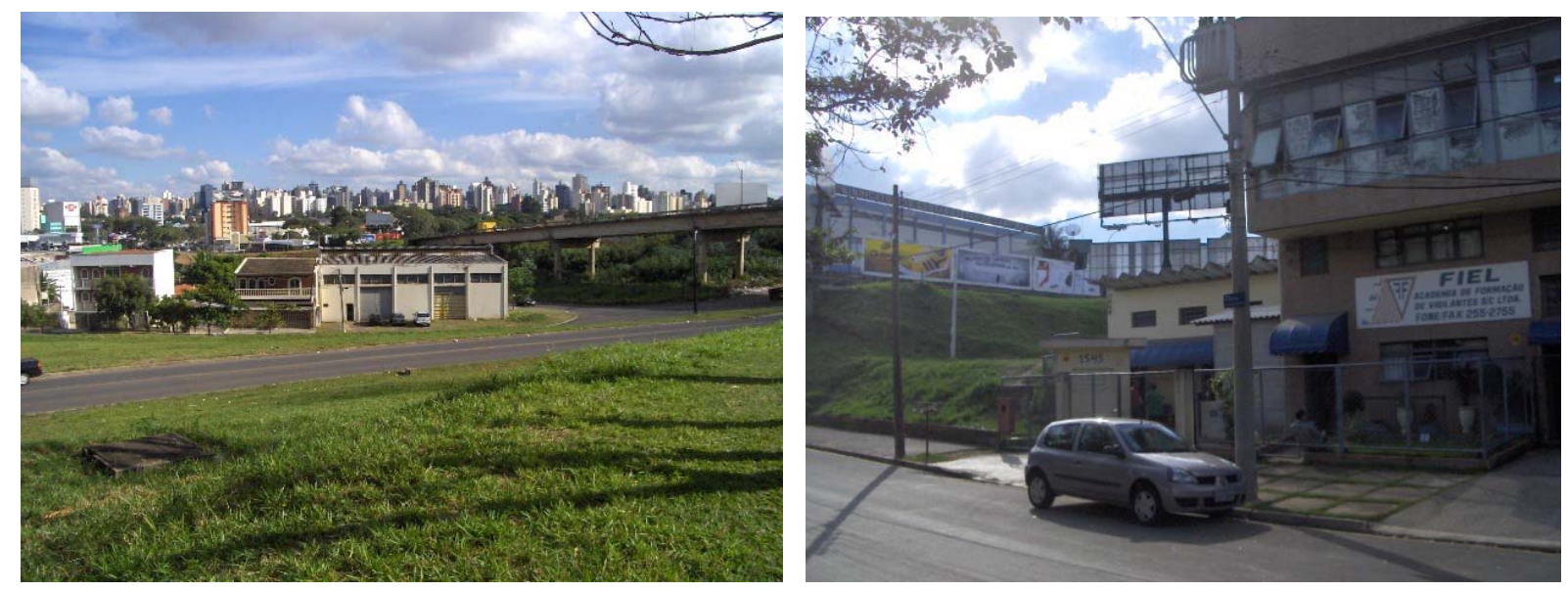

Imagem 74 e 75: Pormenores Setor B: área livre existente com adequada situação urbana e topografia propícia à instalação de Estação Intermodal

Em termos gerais de potencial, o Setor B apresenta-se com boa acessibilidade viária através da Avenida Norte Sul, e mesmo com sistema viário incompleto, permite a movimentação entre bairros, ao longo da gleba.

Apresenta importante potencial para requalificação urbana, ambiental e paisagística a ser explorado.

A integração entre as avenidas, os bairros do entorno e a nova linha de VLT deve configurar-se como um nó de conexões intermodais focado no transporte público e no pedestre, valorizando o espaço público e qualificando esta área de grande potencial para o desenvolvimento e valorização imobiliária.

Nesta gleba de interface da "Cidade Tradicional" com a cidade da "Dispersão Urbana", novos usos metropoltanos e regionais podem ser explorados, devido ao perfil de interligação da cidade em escala urbana: no sentido leste-oeste pelo sistema de VLT e no sentido norte Sul pela Avenida Norte Sul até o Anel Viário de Campinas ( Rodovia Dom Pedro I). 


\section{Setor C}

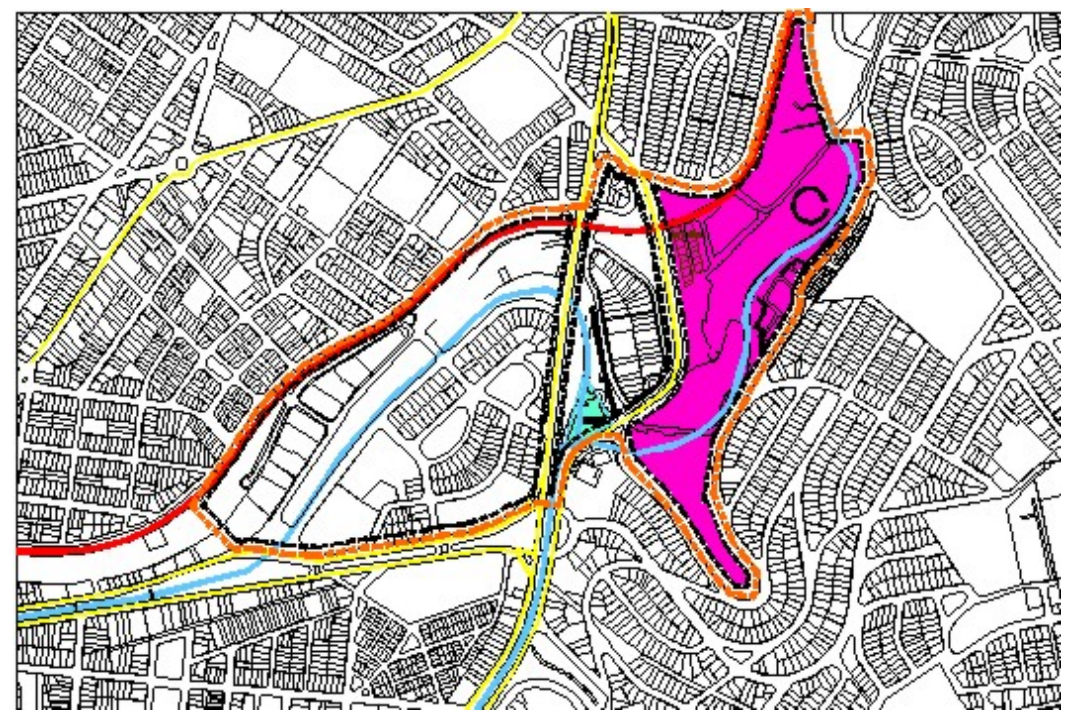

Imagem 76: Setor C com o ribeirão Anhumas e o Leito Ferroviário correndo paralelos.

O Setor C possui área de cerca de 16,30 ha, situado à leste da área do Projteto Urbano Anhumas, é configurado como uma grande área livre às margens do ribeirão Anhumas(ver imagens 49 e 50).
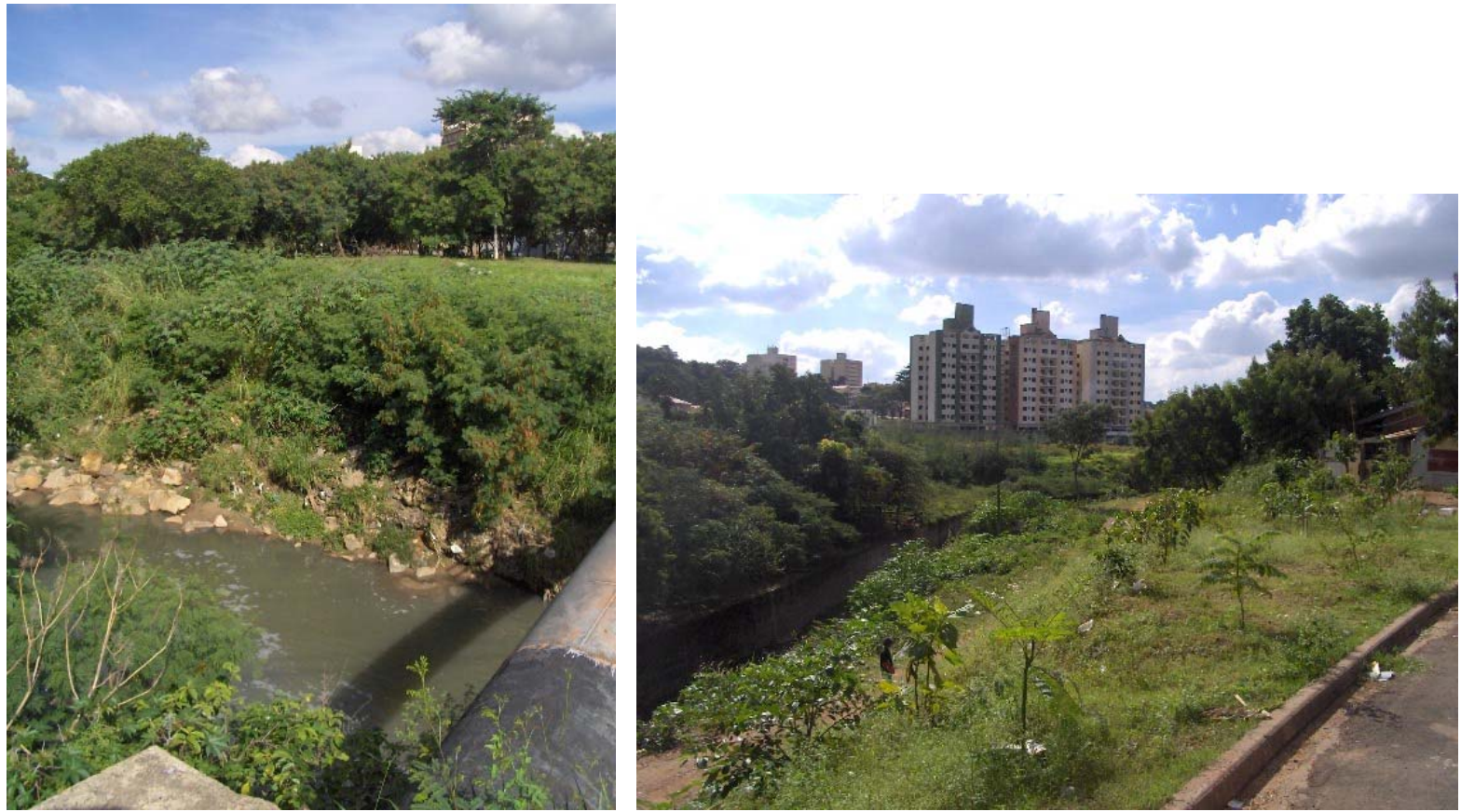

Imagem 77 e 78: Pormenores Setor C: Ribeirão Anhumas e seu leito em área verde degradada. 
Possui área livre chamada "Praça Natividade" (ver imagens 51 e 52) que, mesmo densamente arborizada não se configura como uso adequado ao lazer. Seu entorno é de bairro residencial de classe media baixa, caracterizado por residências unifamiliares isoladas no lote (ver imagens 53 e 54).
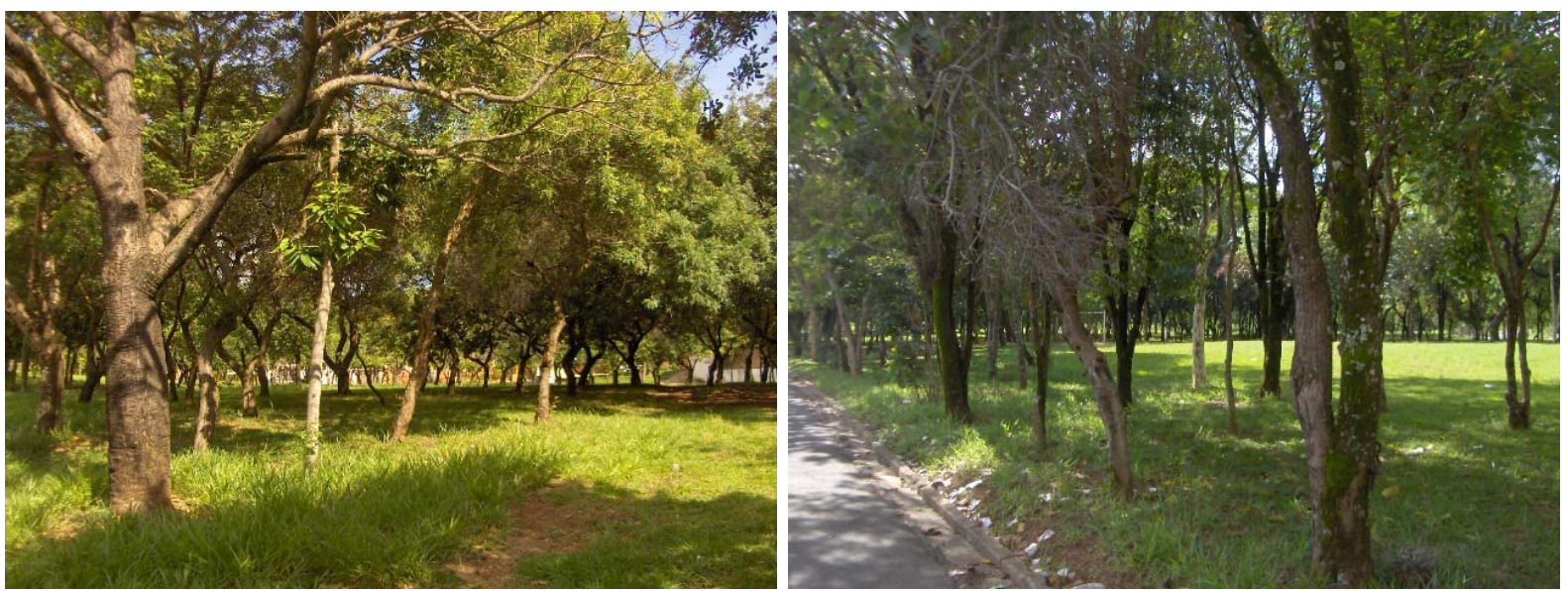

Imagem 79 e 80: Pormenores Setor C: Praça Natividade e sua densa arborização aleatória, sem projeto paisagístico.
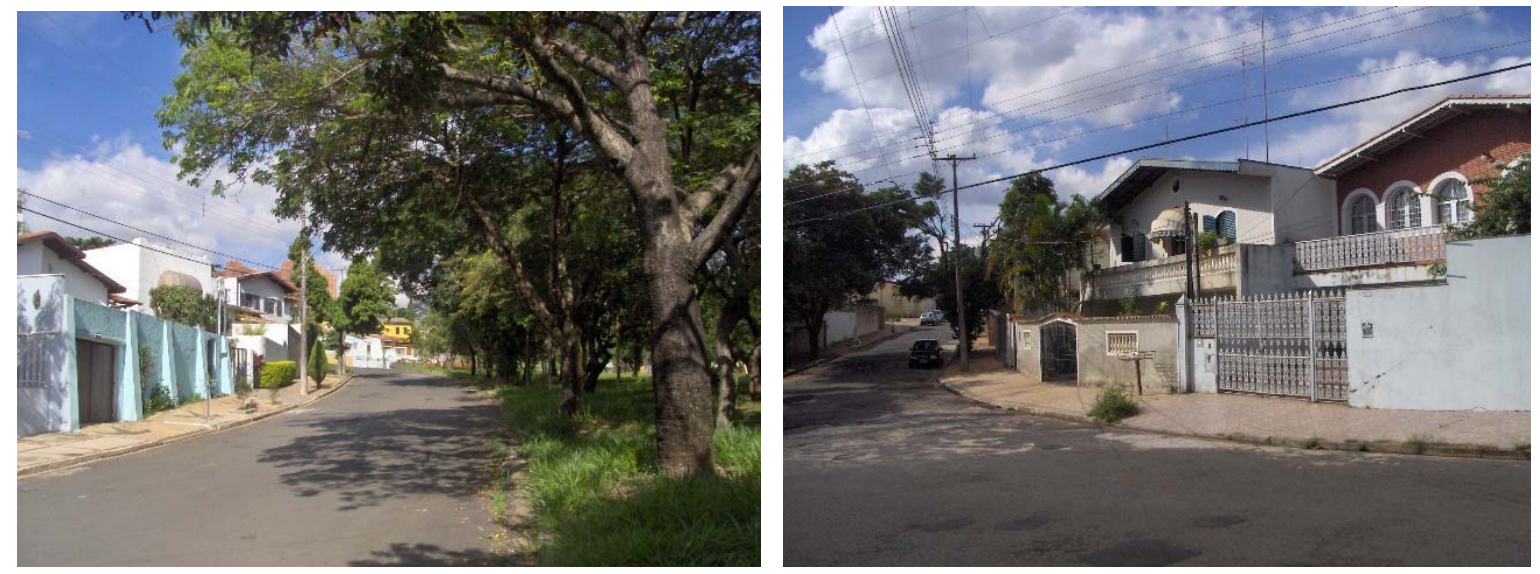

Imagem 81 e 82: Pormenores Setor C: Habitação e a relação urbana com a praça Natividade

Possui área de sub-habitação que está em fase de requalificação urbana por parte da Prefeitura de Campinas, que já construíu 40 unidades, atendendo metade das 80 famílias do local (ver imagens 55 e 56). 


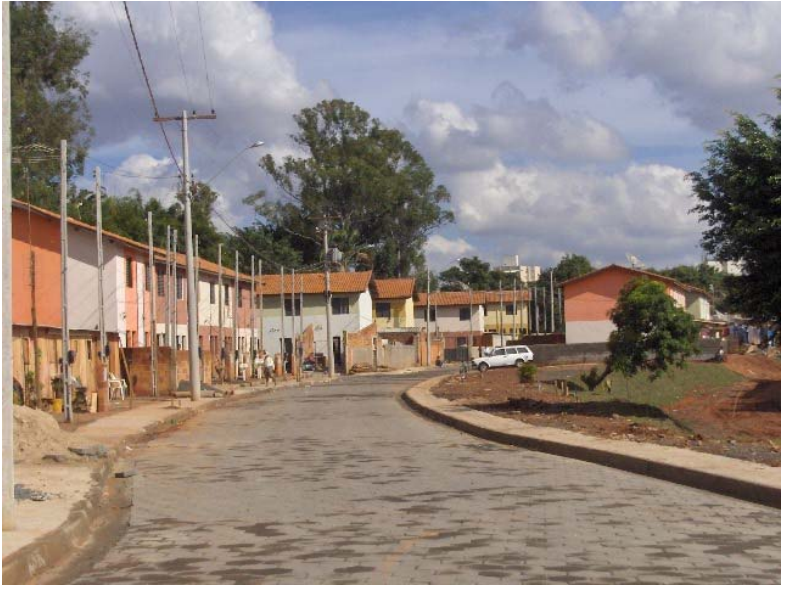

Imagem 83 e 84: Pormenores Setor requalificada e detalhe das unidades.

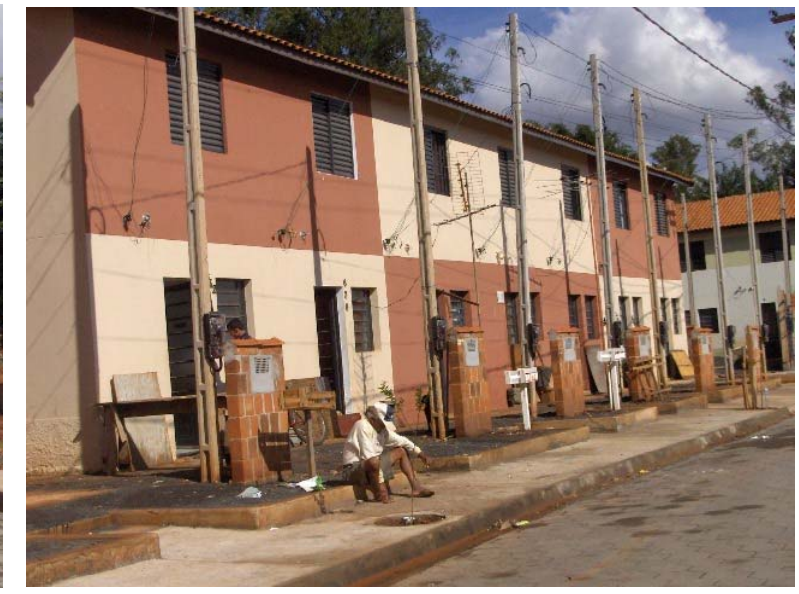

C: Vista da implantação da habitação

O Leito Ferroviário corre paralelo ao ribeirão, e entre estes dois elementos existe uma urbanização que apresenta desde a configuração de subhabitação requalificada (ver imagens 57 e 58 ), edifícios habitacionais isolados ( ver imagens 59 e 60 ) e em conjunto (ver imagens 61 e 62).
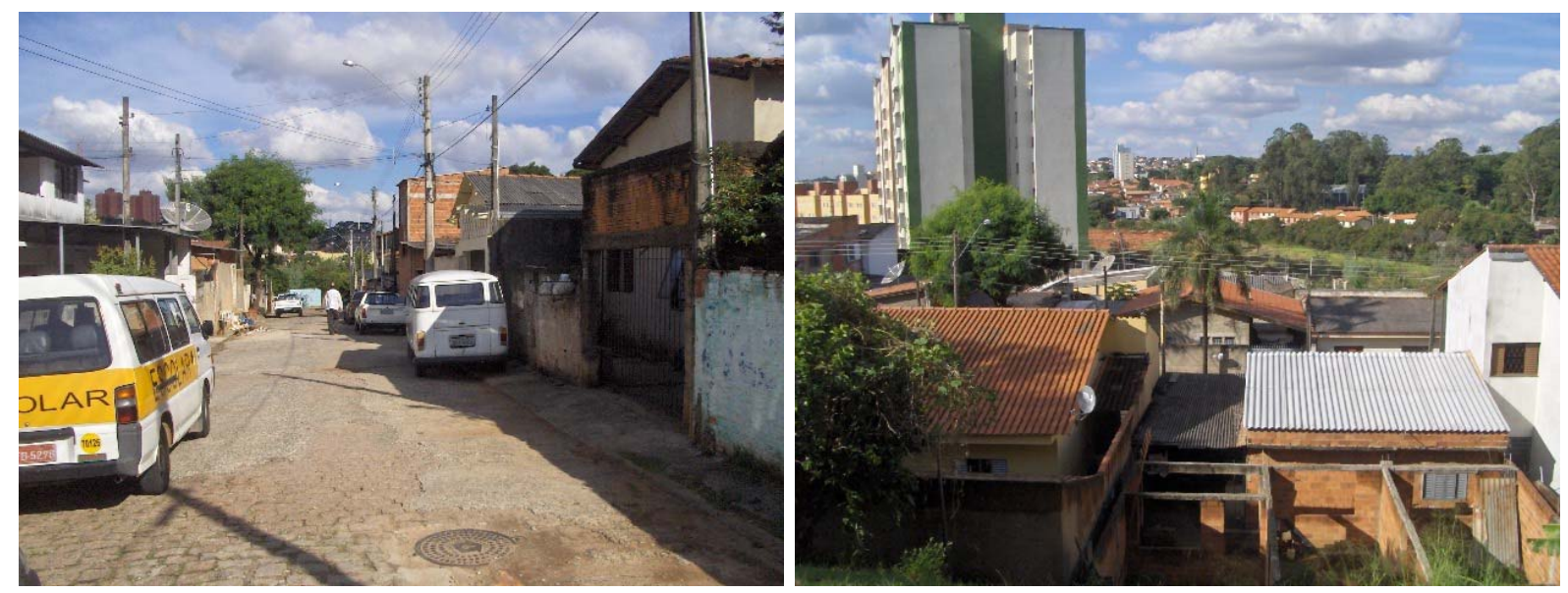

Imagem 85 e 86: Pormenores Setor C: Vista das habitações requalificadas . 

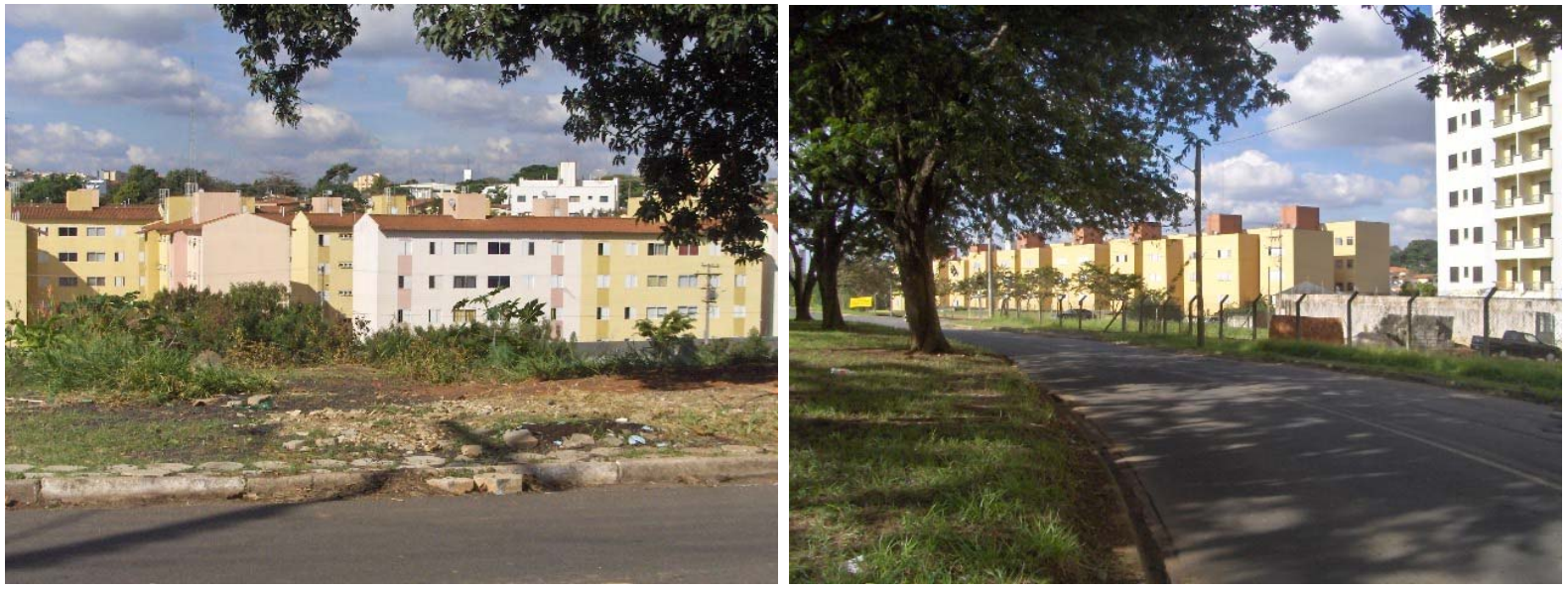

Imagem 87 e 88: Pormenores Setor C: Vistas do conjunto habitacional.
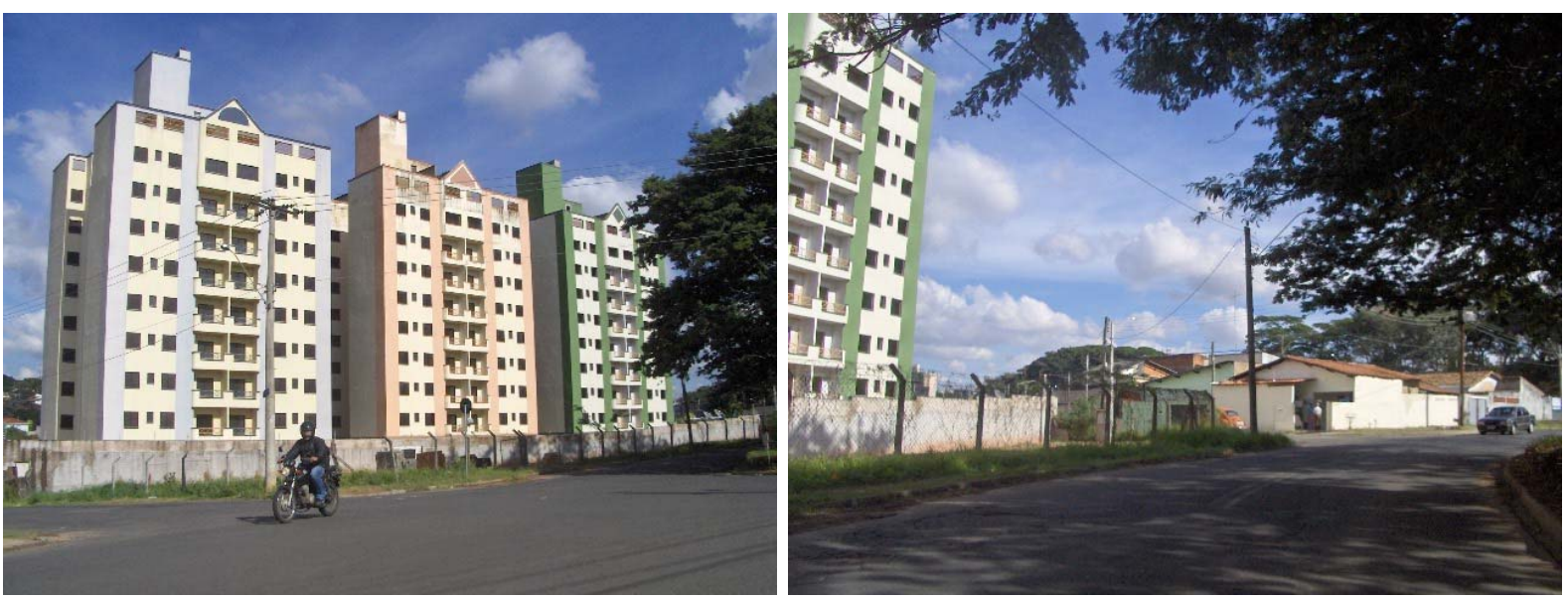

Imagem 89 e 90: Pormenores Setor C: Vistas dos edifícios isolados e sua relação urbana com a área de habitação.

O Setor C se apresenta, portanto, como elemento de grande potencial ambiental e paisagístico. Está latente a configuração de Parque Urbano de lazer e contemplação.

A descontinuidade do sistema viário atualmente isola e fragmenta o tecido urbano do entorno, mas os espaços sub utilizados se encontram na sua maioria como espaços livres, o que facilita a inserção de novas ruas e avenidas, sem o custo da desapropriação.

Uma nova acessibilidade através da implantação de estação de VLT integrado ao Sistema Municipal de transporte público deverá criar fluo de pessoas ao novo Parque.

O entorno consolidado de bairros residenciais configura-se como elemento âncora para atrair novas funções e de novos usos, complementares ao existente. 
Esse fator demonstra o potencial de desenvolvimento e valorização imobiliária do setor, minimizando o impacto das áreas de requalificação das habitações para população de baixa renda.

\subsubsection{PROJETO URBANO ANHUMAS}

As contribuições para o Projeto Urbano Anhumas partem da leitura metropolitana da cidade de Campinas, pormenorizada em questões julgadas pertinentes ao melhor entendimento da área de estudo. Entende-se, resumidamente, como papel do projeto urbano a capacidade de propor alternativas de estruturação e configuração do tecido urbano, propor transformações de setores abordando acessibilidade, mobilidade e usos, regular a atuação da iniciativa privada e prever estoques de áreas. Esses objetivos são obtidos, interrelacionando-se as escalas e temas, através do parcelamento, da definição da infra-estrutura e das edificações, inseridas num contexto da dinâmica metropolitana contemporânea.

\section{PREMISSAS}

O desenvolvimento das diretrizes urbanísticas decorre das especificidades físico-territoriais analisadas sob tal ótica metropolitana.As diretrizes e as intervenções propostas partem do estabelecimento de diversas premissas norteadoras do Projeto Urbano Anhumas. Estas premissas são embasadas em estudos elaborados pelas diversas escalas de governo e com amplo apoio da sociedade civil e empresarial. Como exemplos citamos:

1) Conexão ferroviária entre São Paulo e Campinas, o chamado expresso Bandeirantes, que conectará o Aeroporto de Viracopos ao Terminal Intermodal Barra Funda, em São Paulo, e deste ao Aeroporto Internacional de Cumbica, em Guarulhos. Este estudo é parte do plano da Infraero, portanto do Governo Federal.

2) Conexão Ferroviária entre o Aeroporto de Viracopos e o centro de Campinas, até a Estação Central, junto ao novo Terminal Rodoviário. Plano de responsabilidade do Governo Municipal.

3) Implantação de Transporte Inter Metropolitano (TIM) utilizando os antigos leitos ferroviários para conectar as cidades da Região metropolitana de Campinas. Cruzará o território municipal no sentido Norte Sul, conectando 
a cidade de Valinhos à Hortolândia. A Estação Central de Campinas será o ponto de principal articulação com outros modos de transportes e o centro da cidade. Plano de responsabilidade do Governo Municipal.

4) Implantação de Veiculo Leve sobre Trilhos (VLT) cruzando o município no sentido leste - oeste, com função de transporte público de massa em escala intermunicipal. Plano de responsabilidade do Governo Municipal.

5) Em relação ao Meio Ambiente, parte da premissa integração ao Sistema de Eixos Verdes, conforme Plano Diretor Municipal de 2006, em áreas ao longo dos ribeirões e córregos tratados como Parques Lineares.

6) Em relação ao Plano Diretor de Campinas, parte da premissa, entre outras, de adequação às diretrizes gerais e de macrozoneamento, entre elas a diretriz de integração entre os tecidos urbanos. Esta é uma questão referencial em relação à urbanização dispersa e a cidade tradicional . 


\section{PROJETO URBANO ANHUMAS - CONCEITO GERAL}

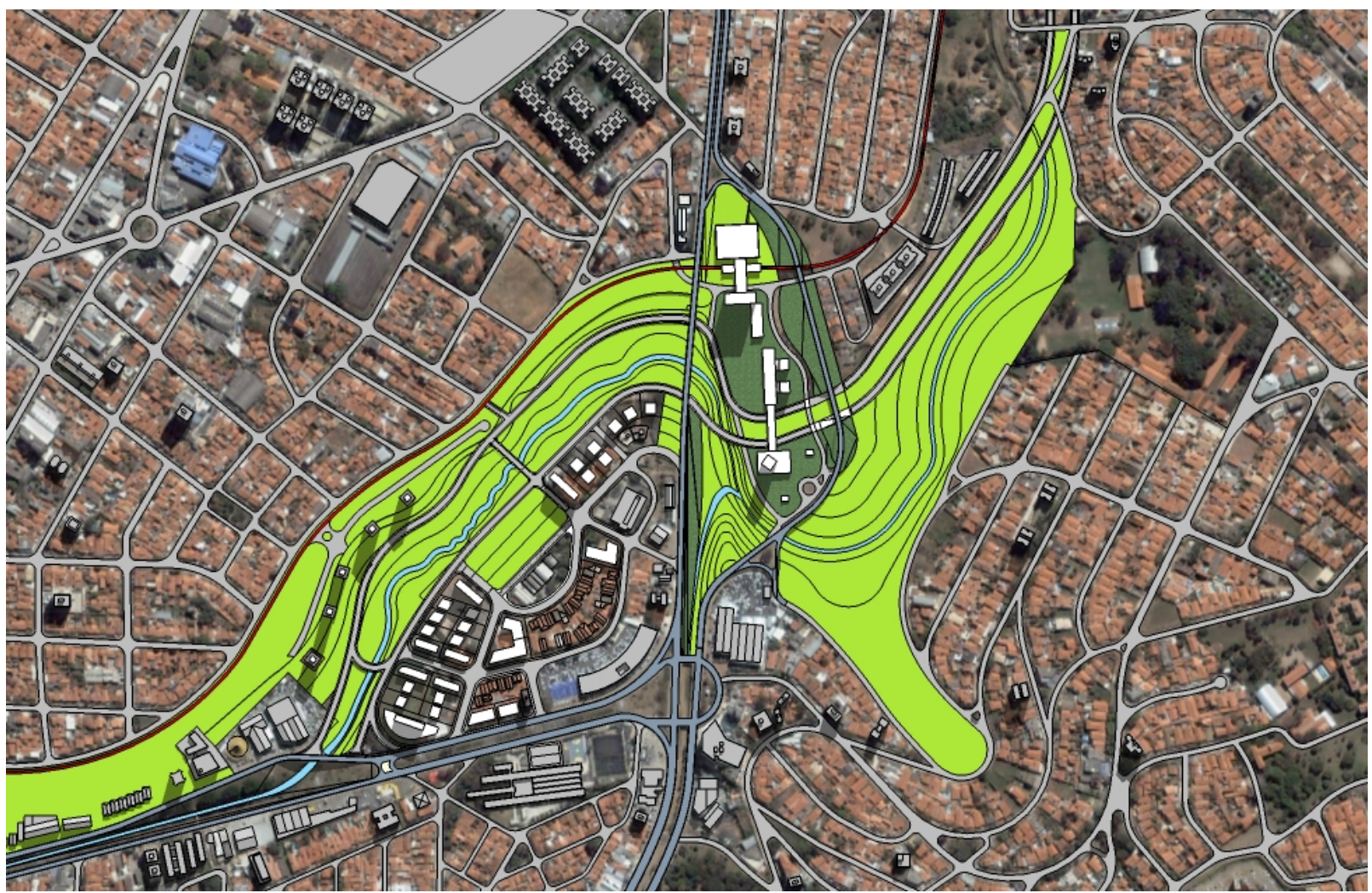

Imagem 91: Projeto Urbano Anhumas- Implantação geral.

A constatação dos estudos realizados é que a área se encontra isolada do tecido urbano do entorno e apresenta, entre os maiores problemas, as questões relacionadas ao Ribeirão Anhumas e suas margens, ao Leito Ferroviário desativado, a descontinuidade do sistema viário e as duas alças de acesso viário.

Importante lembrar que a presença dos viadutos se dá, entre outros quesitos, pela necessidade de conexão viária entre a cota topográfica da cidade ao longo da Av. Norte-Sul à cota elevada situada nas imediações do entorno. Esta conexão viária deve, simultaneamente, vencer a barreira dos trilhos e do Ribeirão, porém se configura como barreira urbana pois ora esta configurada como ponte elevada ora como via elevada sobre aterro. Esta questão é importante para a definição do partido da intervenção, uma vez que se fossem propostas alternativas de intervenção baseadas em eliminar qualquer dos elementos da paisagem, seja do Ribeirão - através de canalização, seja dos trilhos - que poderiam ser rebaixados ou elevados, mesmo assim, as questões topográficas ainda configurariam a área de estudo como uma área de abordagem complexa. 


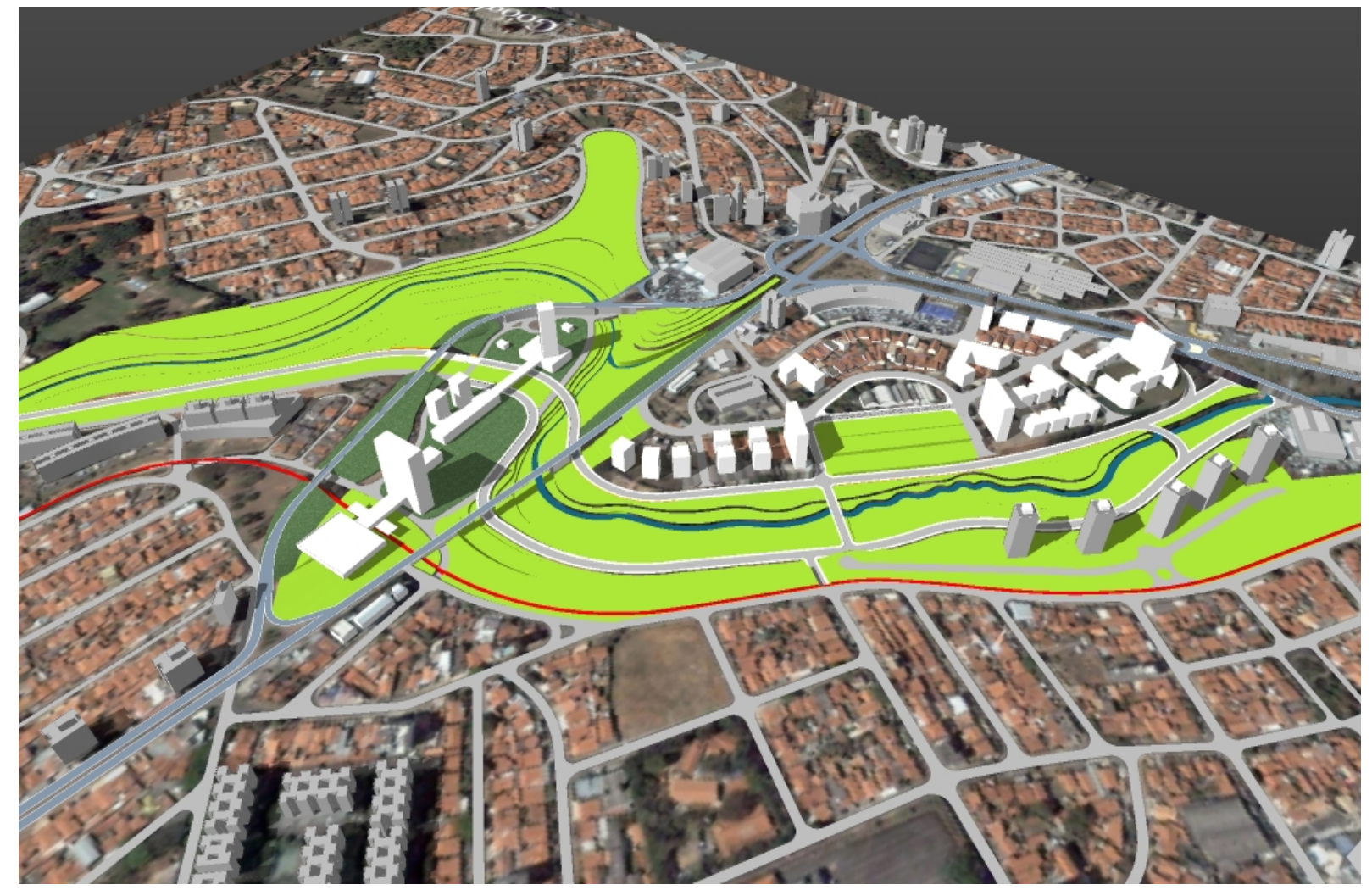

Imagem 92: Projeto Urbano Anhumas - Vista geral.

O partido adotado foi o de considerar as condições atuais como indutoras de um novo processo de intervenção, estruturado por dois eixos de abordagem: o solo público e o solo privado, sendo que a qualidade da intervenção será resultado, entre outros fatores, pela correta relação entre os dois.

Em relação ao solo público, cria-se o Parque Linear às margens do Ribeirão Anhumas - a ser integrado aos Eixos Verdes Metropolitanos, com o objetivo de integrar fragmentos isolados. O entorno do Ribeirão Anhumas passa de barreira física ao papel de articulador das intervenções, estruturando a implantação das funções e dos equipamentos. Ao longo da várzea é proposta a Avenida Parque.

A relação entre o espaço público e o privado é intermediada pela questão da acessibilidade, dada em dois momentos: A Avenida Parque e a Interligação Ferroviária.

A Avenida Parque, prolongamento do sistema viário existente, conecta a área aos acessos viários da Rodovia Dom Pedro. 




Imagem 93: Projeto Urbano Anhumas- Vista geral.

Esta conexão tem papel importante na definição dos usos propostos, pois é a interligação da rodovia Dom Pedro I com o Centro expandido. Dada esta situação, a implantação de setores de Serviços, Comércial e Institucional, entre outros, passam a ser possíveis na área de estudo.

A Interligação Ferroviária entre a área e o centro da cidade, e deste ao Aeroporto de Viracopos, amplia as possibilidades de instalação de edificações de diferentes usos, voltados aos usuários em diferentes escalas, do local ao internacional.

Quanto ao solo privado, as soluções de desenho urbano propostas são baseadas no desenho das quadras, intermediadoras da metrópole e a pequena escala. Repensar a quadra significa repensar as relações entre os edifícios e a cidade e também o papel da rua. As quadras, constituídas de variações tipológicas dos edifícios, variações de gabarito e de alinhamento, permitem manter a legibilidade da rua como espaço público estruturador da cidade.

Para melhor entendimento das propostas, as intervenções foram divididas em setores A, B e C, conforme apresentado no capítulo anterior. 


\section{SETOR A - MEMORIAL CONCEITUAL}

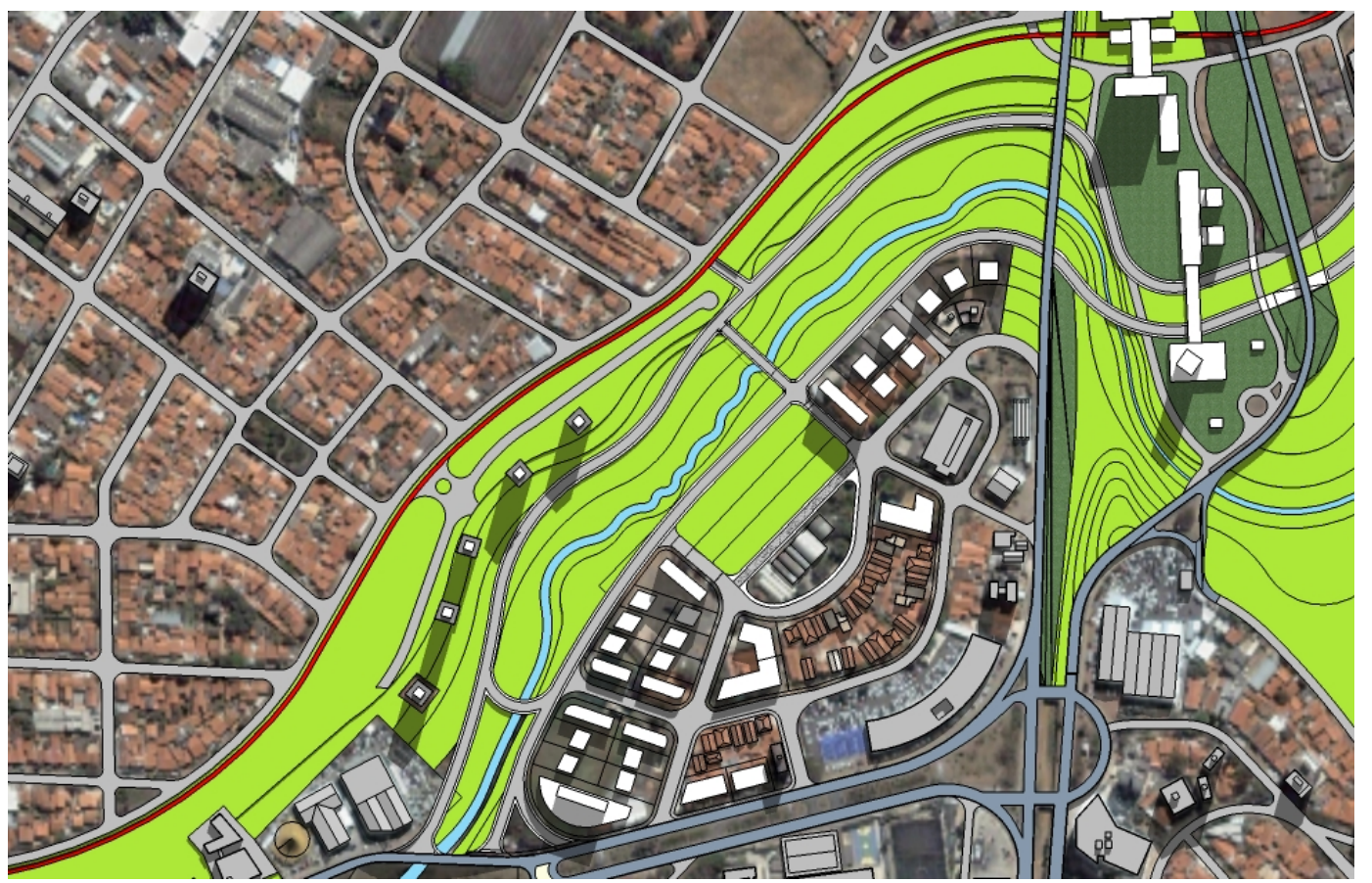

Imagem 94: Setor A - Implantação geral.

No Setor A, ao norte, junto ao limite com o bairro Taquaral, nas imediações da rua Paula Bueno, procurou -se viabilizar a integração com a parte Sul bem como a urbanização, via Parque Linear, da encosta existente.

No Setor A, ao sul - imediações da Igreja Menino Jesus de Praga a redefinição das quadras partiu do entendimento que o sistema viário deveria sofrer alterações para promover uma maior legibilidade do desenho geral. Para isto foi necessária a criação de algumas ruas e a inutilização de outras.
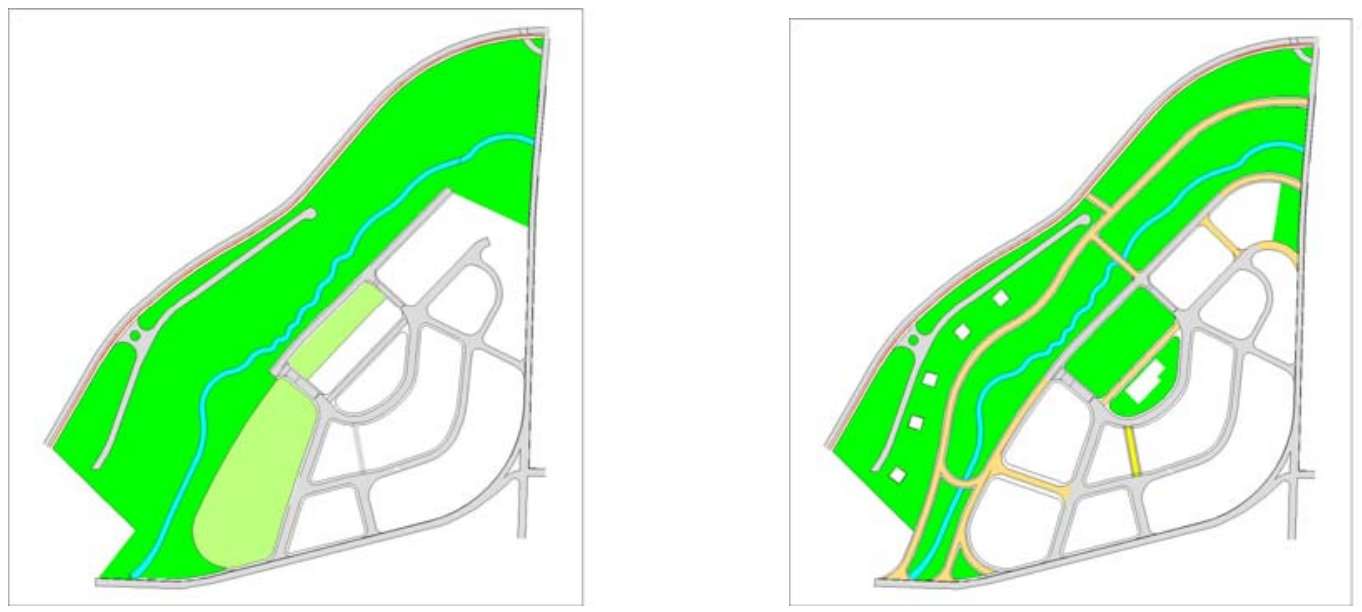

Imagem 95 e 96: Setor A - Situação Existente e Novo Viário em cor laranja. 
A melhoria da acessibilidade local do bairro com a Av. Norte-Sul assim como a relação das novas quadras em relação a Avenida Parque teve como objetivo dar continuidade e fluidez ao desenho concêntrico da estrutura viária existente. A proposta reforça o caráter do arruamento existente de modo a criar uma identidade de lugar diferenciado na malha da cidade.

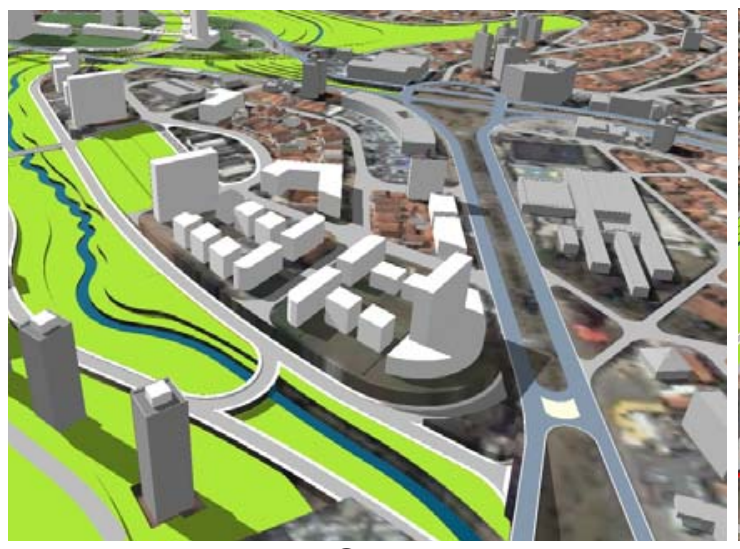

Imagem 97 e 98: Setor A - Vistas gerais do Setor A no contexto urbano

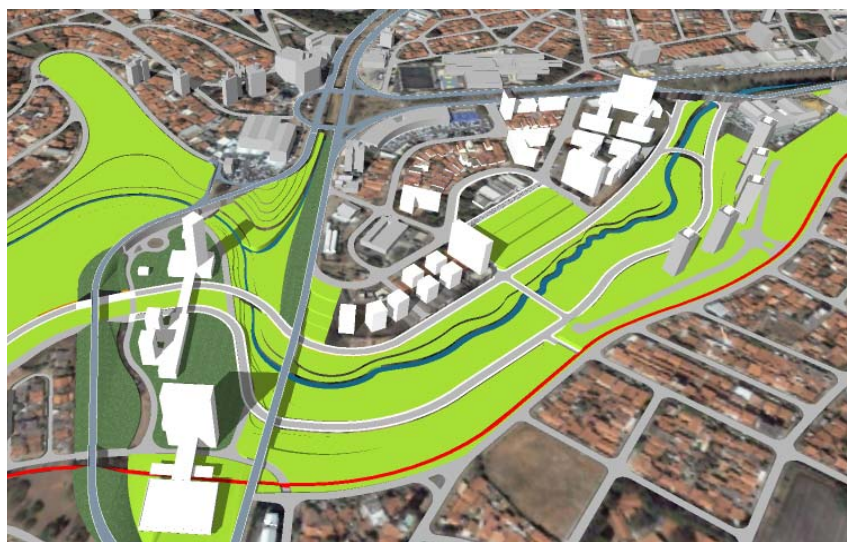

A principal articulação espacial desta área se dá pela sucessão de novas quadras ao longo da Avenida Parque. Esta seqüência é interrompida em um ponto de exceção, na Quadra da Praça. Ela se caracteriza pela ausência de construções, e pela relação desta área livre com o edifício da Igreja Jesus de Praga. A rua entre a Igreja e a praça será calçada com pavimento diferenciado do das outras ruas, e nivelado com a calçada. Desse modo, fisicamente, fica definida a prioridade do pedestre em relação ao automóvel, que deverá ter fluxo somente esporádico.
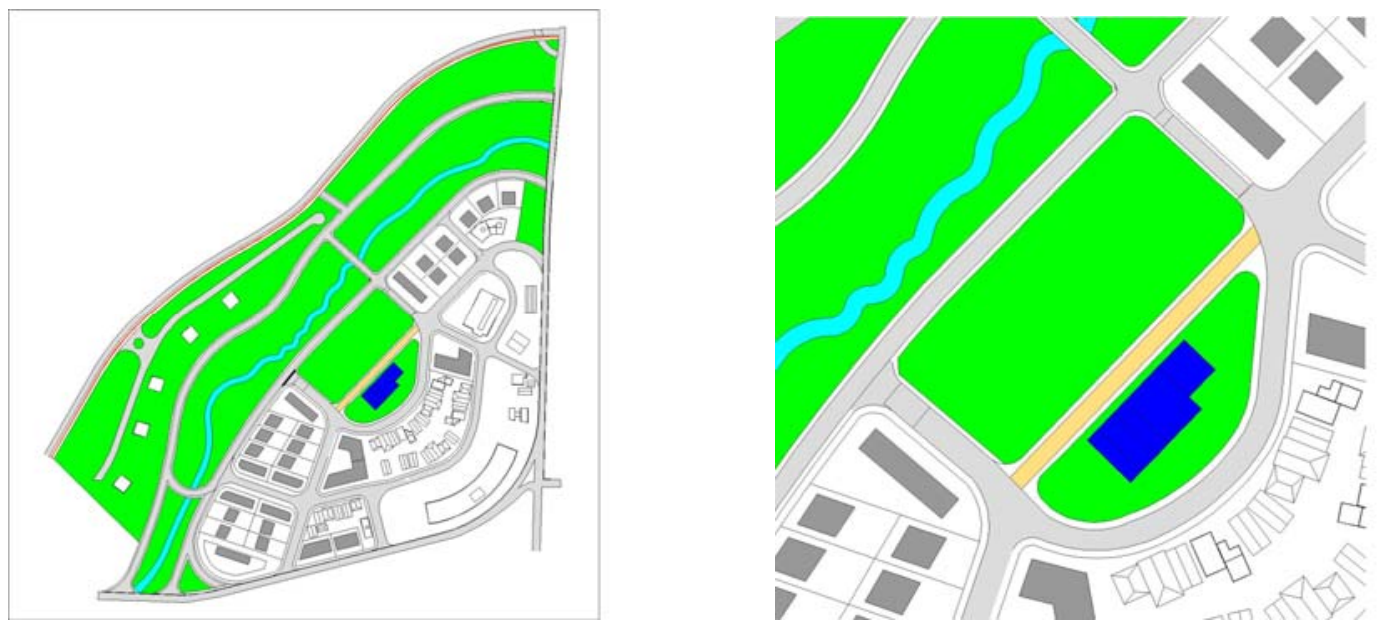

Imagem 99: Setor A - Ilustração da implantação da Praça e Zoom da Quadra da Praça 
A outra característica importante da Quadra da Praça é o fato de ser um espaço onde o Parque Linear, ao longo da Avenida Parque, obtém maior expressividade, através da integração entre as escala metropolitana e a local. O Parque Linear deixa de ficar confinado ao vale entre as vias e passa a reordenar a definição do espaço privado.

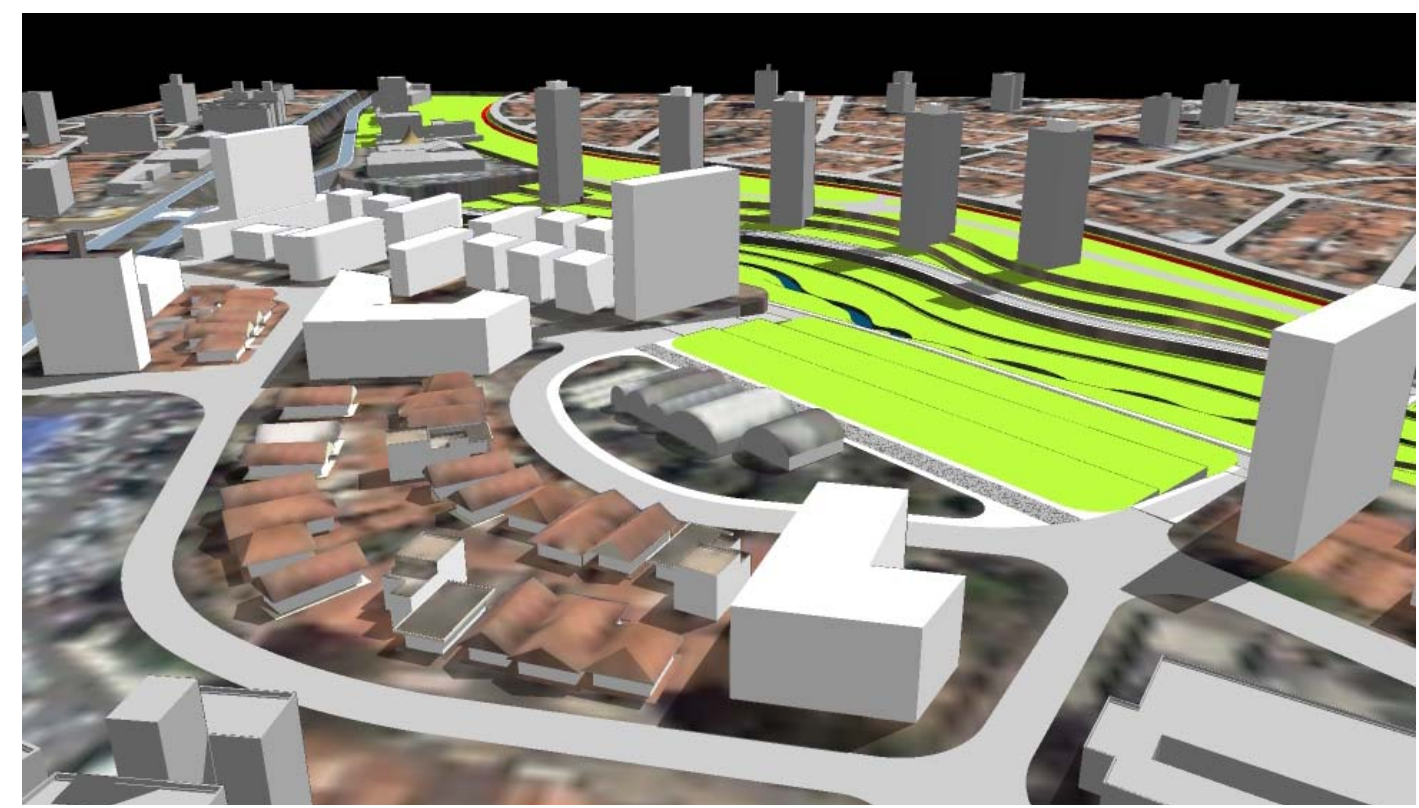

Imagem 100: Setor A - Ilustração da implantação da Praça

A volumetria das edificações junto à praça é definidora de um espaço vazio entre outros de média densidade. Essa volumetria reforça, ainda, a situação geográfica, pois estando o observador junto à igreja, a paisagem avistada entre as duas edificações propostas terá como pano de fundo a Avenida Parque e a vegetação na encosta do morro. Importante lembrar que a Quadra da Praça tem a regularidade das outras quadras, possibilitando ao espaço livre se destacar pelo caráter exceção.
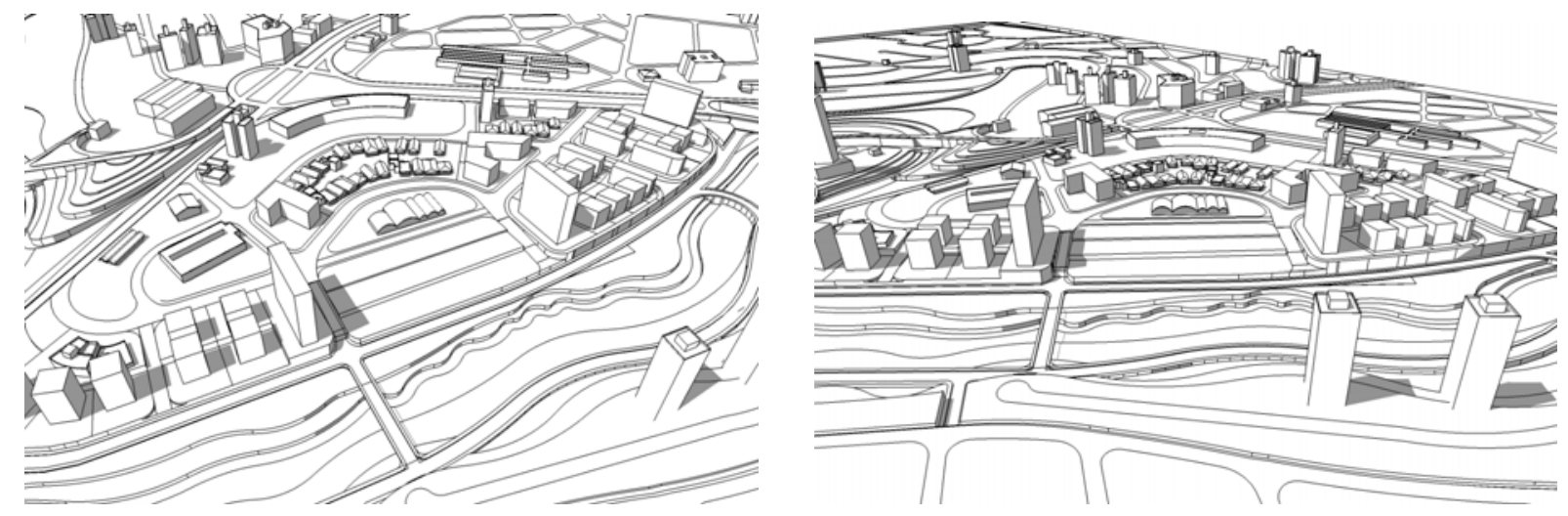

Imagem 101 e 102: Setor A - Ilustração da implantação da Praça 
As outras quadras situadas ao longo da Avenida Parque possuem dimensionamentos semelhantes, e volumetria que explora os espaços entre as edificações como característica principal. Diferentes alinhamentos e recuos permitem permeabilidade visual, facilitando a visualização do Parque Linear e a criação de uma seqüência referencial diferenciada ao percurso do pedestre.

O dimensionamento das quadras e a variação dos gabaritos, recuos e alinhamentos permite uma integração das quadras propostas ao tecido urbano existente e à sua volumetria. A interface entre as quadras projetadas e as existentes resultam em um conjunto urbano único, dinâmico, que passa a ser reconhecido como parte integrante da cidade consolidada, alinhado com os conceitos de "Quadra aberta" apresentados por Christian de Portzamparc em sua proposta para o bairro Massena, no Projeto Urbano Rive Gauche, em Paris, conforme descrito no capítulo anterior.

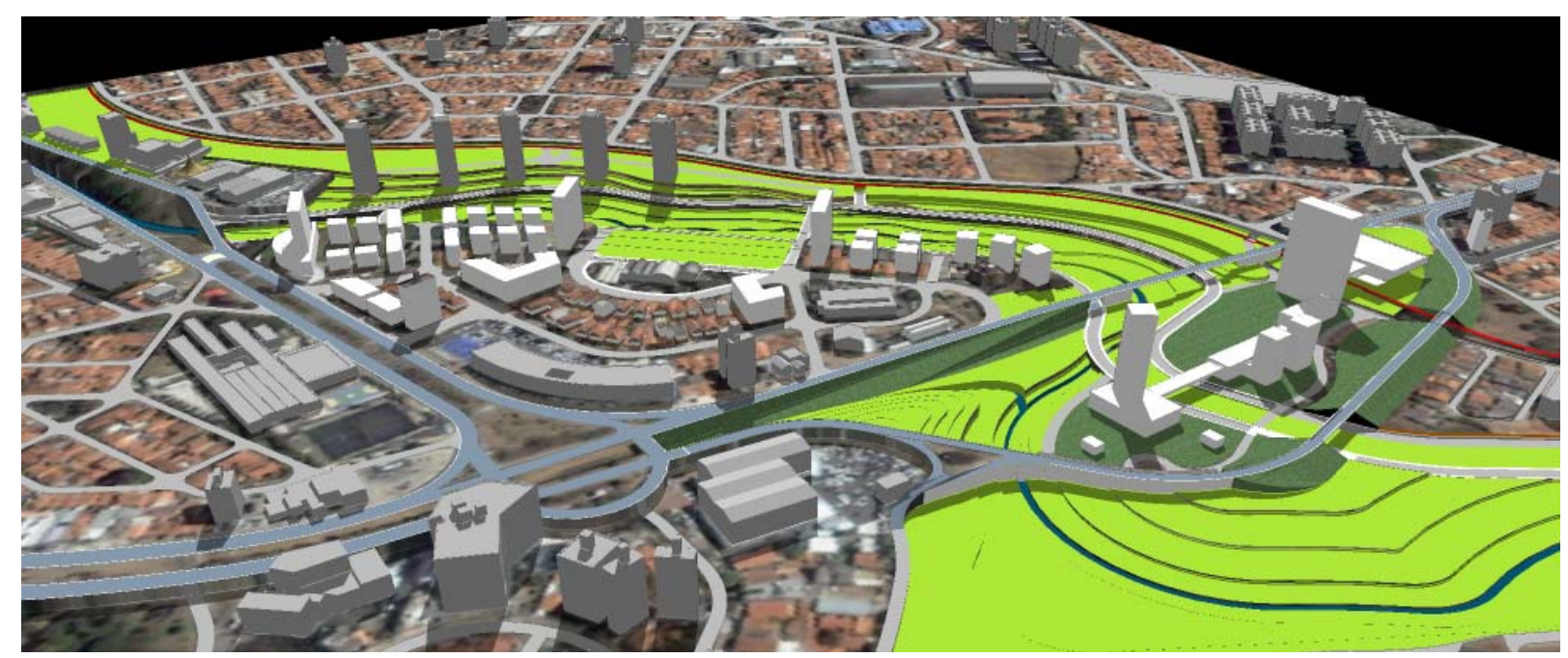

Imagem 103 : Setor A - Integração ao Parque Linear e ao tecido urbano existente

São previstos diferentes usos para esta área, de modo a fortalecer uma dinâmica urbana intensa, com mix de funções complementares e com diferentes perfis de moradores. 


\section{SETOR A - MEMORIAL DESCRITIVO}
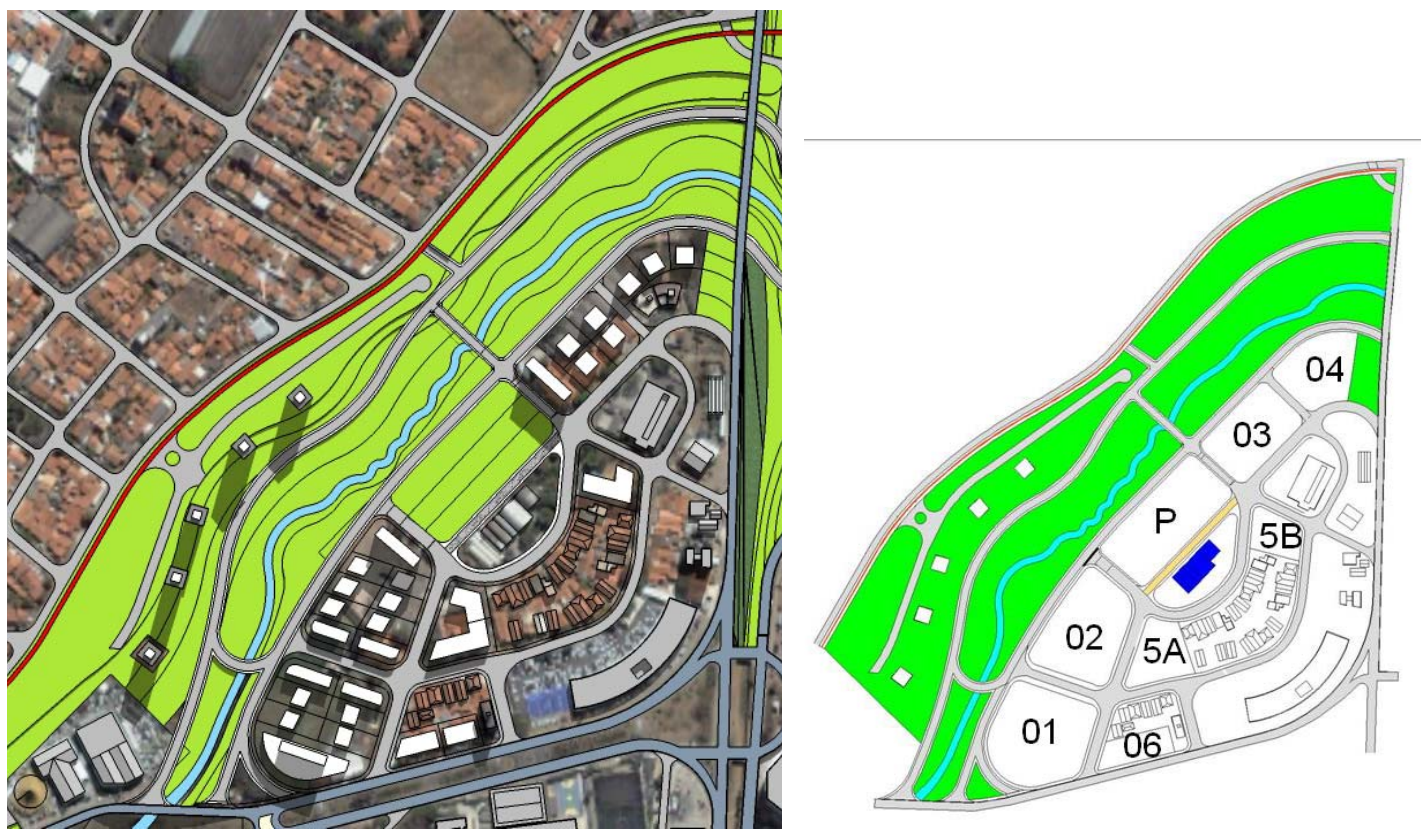

Imagem 104 e 105: Setor A - Vistas da implantação das quadras.

O Setor A possui área total de $230.630 \mathrm{~m} 2$.

A Avenida Parque, ocupa o fundo de vale, totalizando $63.354 \mathrm{~m} 2$

A antiga parte denominada Bairro Paula Bueno, com 55.692 m2, foi subdividida em duas partes:

Uma, de 38.345 m2 foi destinada a um empreendimento imobiliário, em fase de implantação, configurado por 5 torres de uso habitacional de alta e média renda.
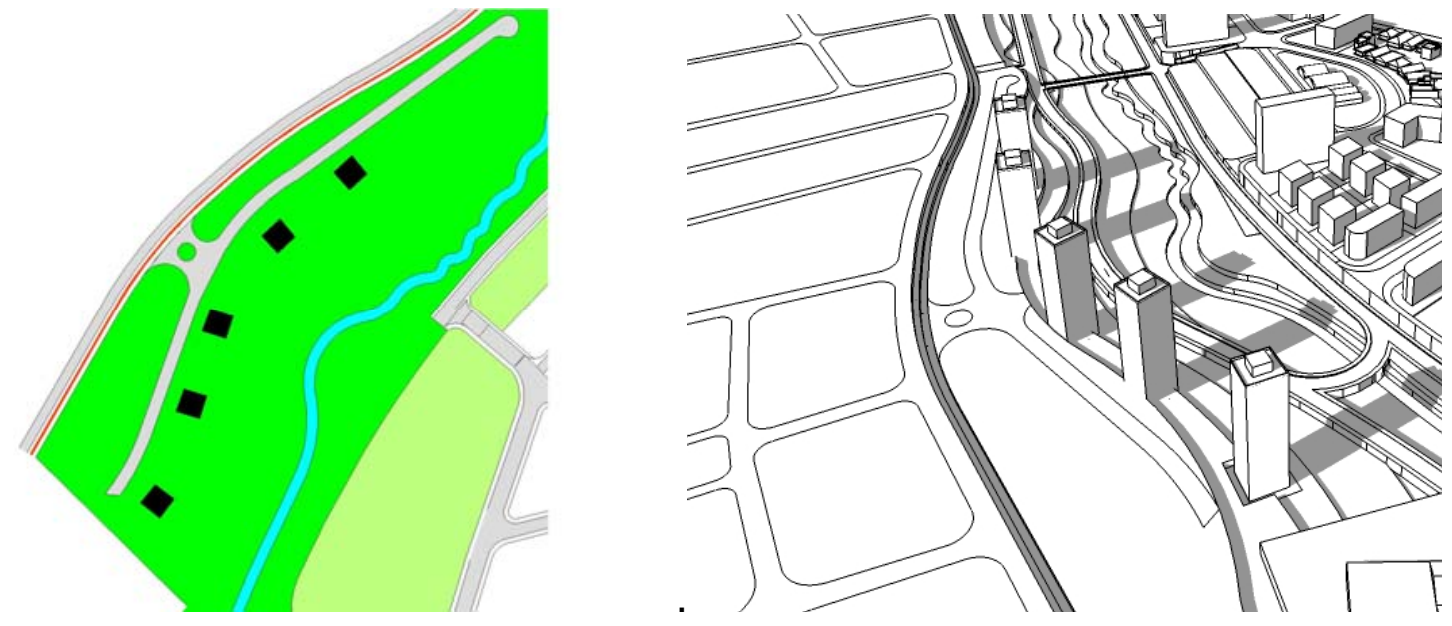

Imagem 106 e 107: Setor A - Ilustração dos edifícios propostos pelo mercado imobiliário em planta e em volumetria. 
A outra parte, de $17.347 \mathrm{~m} 2$ foi caracterizada como parte do Parque Linear.

O Bairro Menino Jesus de Praga tem uma área total de 111.584 m2.

Uma área de 48.559 m2 não foi afetada diretamente pela intervenção proposta.

Os restantes $67.714 \mathrm{~m} 2$ sofreram alterações, como a alteração do lote da Igreja Jesus de Praga, que foi ampliado para 5892 m2 e o sistema viário e as calçadas, que ocupam $11.131 \mathrm{~m} 2$.

O restante de $40.691 \mathrm{~m} 2$ foram distribuídos em 07 quadras somando $40.691 \mathrm{~m} 2$ de área total.

Destes, 8856 m2 são destinados à quadra da praça.

Os outros 31.835 m2 estão em 06 quadras, subdivididas em 28 lotes.

São previstos 59.785 m2 de área total a ser construída, com coeficientes de aproveitamento variantes de 1,69 a 2,03. 


\section{QUADRA 01 - MEMORIAL CONCEITUAL}

A Quadra 01, situada junto à av. Orozimbo Maia, tem como característica volumétrica, a diversidade de gabaritos e funções.

O lote 01 apresenta edifício constituído de Base e Torre, de modo a adensar a ocupação do lote que está na confluência de avenidas de grande fluxo. $\mathrm{O}$ uso proposto para a Base é de centro comercial, enquanto que a torre é voltada aos escritórios de profissionais liberais. O alinhamento da torre é paralelo aos edifícios dos lotes 06 e 07, de modo a circunscrever uma área, à qual pertencem os lotes 02 , 03, 04 e 05. Estes edifícios de uso misto apresentam grandes recuos frontais, enquanto que os edifícios situados nos limites da quadra apresentam recuos menores, configurando um espaço interessante ao percurso do pedestre.

Os edifícios dos lotes 06 e 07 são de uso residencial e se apresentam como os definidores volumétricos da quadra 01.
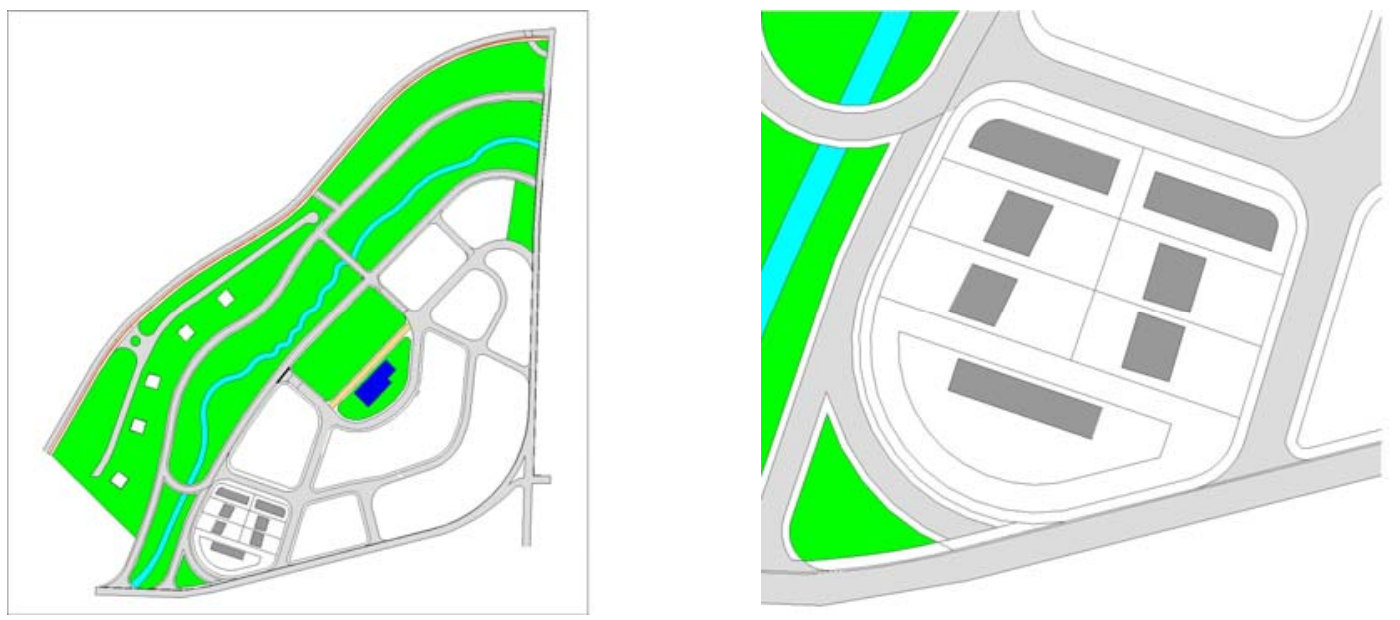

Imagem 108: Setor A - Quadra 01- Implantação Geral e zoom.

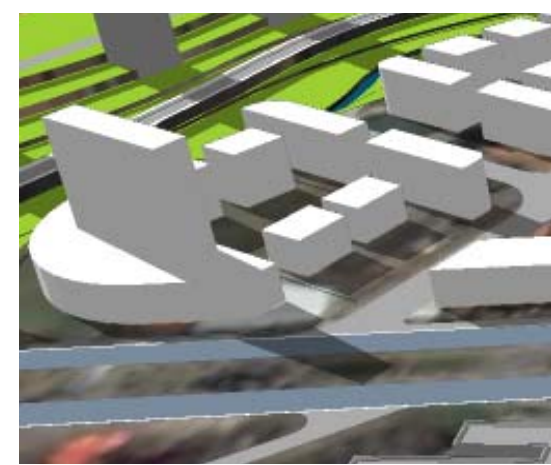

Imagem 109: Setor A - Quadra 01- Implantação Geral 


\section{QUADRA 01 - MEMORIAL DESCRITIVO}

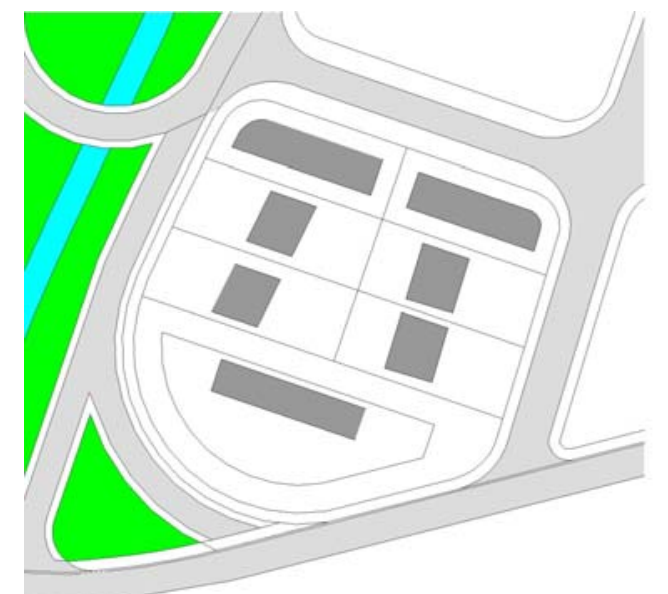

Imagem 110: Setor A - Quadra 01- Implantação

A Quadra 01, tem coeficiente de aproveitamento de 1,69. São $9430 \mathrm{~m} 2$ de terreno, divididos em 07 lotes e com 15940 m2 de área total estimada de construção.

No lote 01, com uma metragem de 3308 m2, onde será construída uma edificação composta de base e torre. A base é de 1260m2, com

4 pavimentos, com altura total de $12 \mathrm{~m}$ somando $5040 \mathrm{~m} 2$.

$O$ recuo e os afastamentos da base são de $7 \mathrm{~m}$.

A torre é constituída por pavimento tipo de $358 \mathrm{~m} 2$, com 10 pavimentos, somando 30 metros de altura e uma área construída total de 3580 m2.

O recuo é de $16 \mathrm{~m}$ sendo que os afastamentos são de $9 \mathrm{~m}$.

Nos lotes 02, 03, 04 e 05, cada um com uma metragem de 1058 m2, onde serão construídas 4 torres, com 5 andares somando 15 metros de altura. $\mathrm{O}$ pavimento tipo é de $179 \mathrm{~m} 2$, perfazendo um total de $895 \mathrm{~m} 2$ cada uma.

Para os lotes 02 e 03,voltados para a avenida, o recuo é de $20 \mathrm{~m}$, sendo que os afastamento lateral é de $3 \mathrm{~m}$ e o afastamento de fundo é de $18 \mathrm{~m}$.

Para os lotes 04 e 05 , voltados para a rua, o recuo é de $20 \mathrm{~m}$, sendo que os afastamento lateral é de $3 \mathrm{~m}$ e o afastamento de fundo é de $12 \mathrm{~m}$

Nos lotes 06 e 07, cada um com uma metragem de $945 \mathrm{~m} 2$, onde serão construídas 2 torres, com 5 andares somando 15 metros de altura. $\mathrm{O}$ pavimento tipo é de $374 \mathrm{~m} 2$, perfazendo um total de $1870 \mathrm{~m} 2$ cada uma.

O recuo e os afastamentos são de $5 \mathrm{~m}$. 


\section{QUADRA 02 - MEMORIAL CONCENTUAL}

A volumetria destaca-se pela variação entre os gabaritos do edifício do lote 09 junto à Quadra da Praça e o dos outros edifícios, como apresentado anteriormente, possibilita definir a Quadra da Praça através de seu espelhamento ao edifício do lote 01 da quadra 03. O uso proposto ao edifício 09 é de habitação.

Os edifícios dos lotes 03,04 e 05, de uso misto, voltados para a Avenida Parque, possuem recuos menores do que os edifícios da Quadra 01, de modo a criar uma variação das elevações quando no percurso da Avenida Parque.

Por sua vez, os edifícios dos lotes 06, 07 e 08, de uso misto, voltados para a rua, possuem um recuo maior em relação à rua, criando um largo em relação à volumetria do edifício situado no lote 05 da quadra 05 . Este contexto será enriquecedor do percurso do pedestre consistindo em variações de configurações do espaço da rua, culminando com a chegada à Quadra da Praça. Os edifícios situados nos lotes 01 e 02, são de uso habitacional.
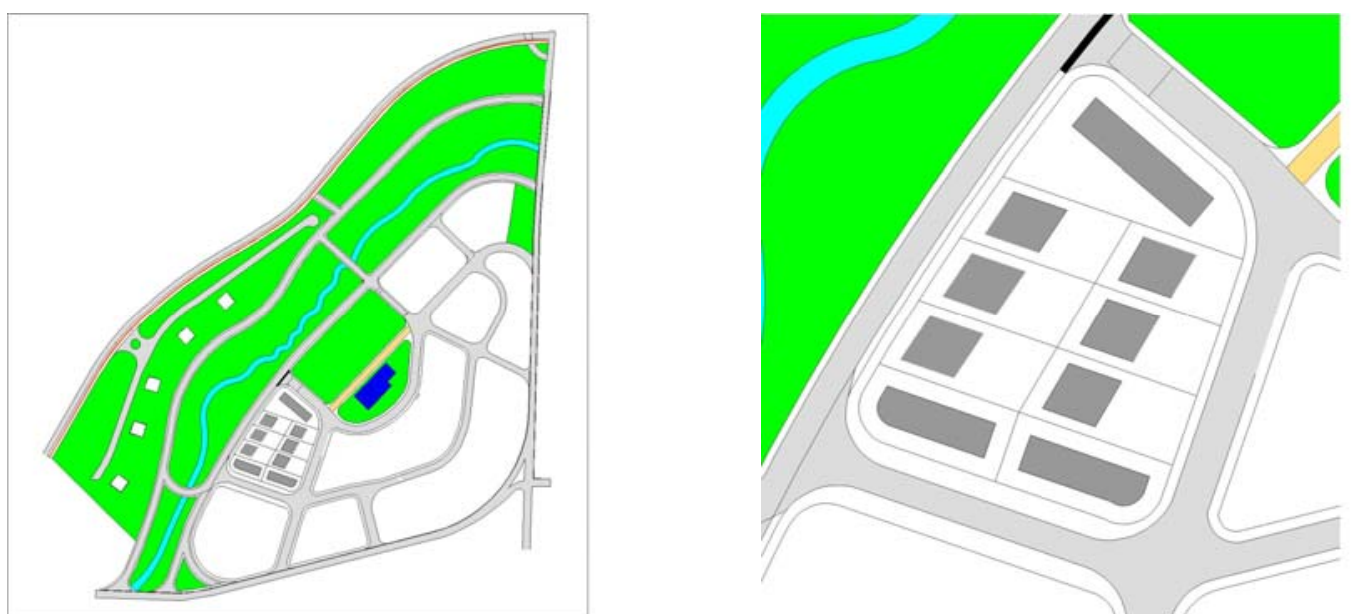

Imagem 111: Setor A - Quadra 02- Implantação Geral e zoom.

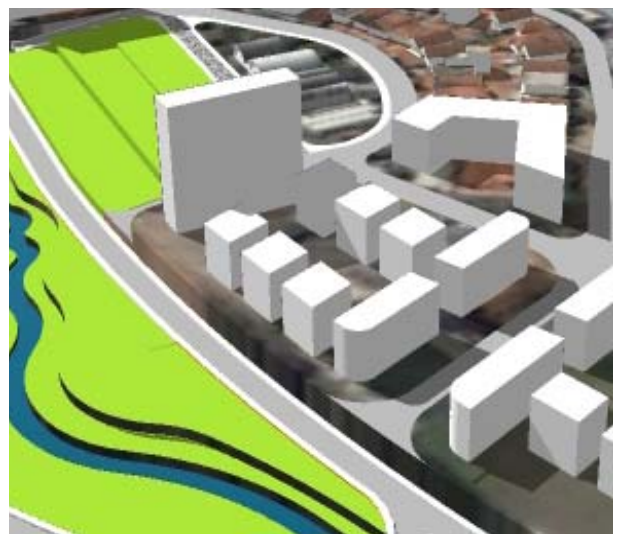

Imagem 112: Setor A - Quadra 02- Implantação Geral 


\section{QUADRA 02 - MEMORIAL DESCRITIVO}

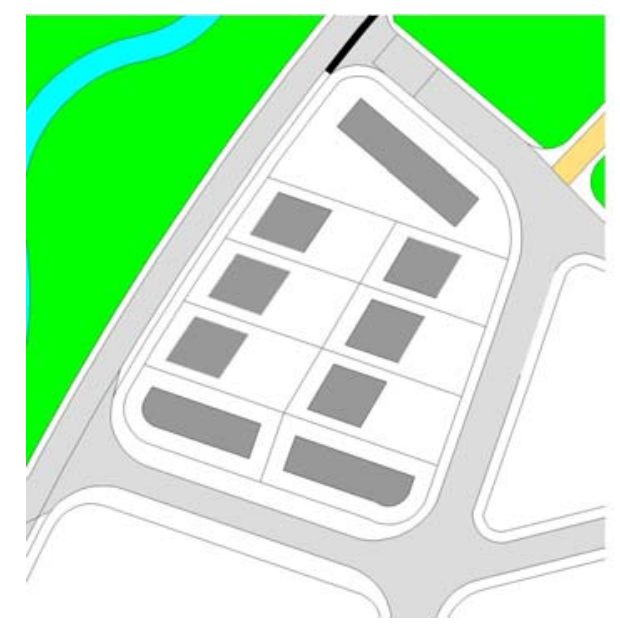

Imagem 113: Setor A - Quadra 02- Implantação Geral

A Quadra 02, têm coeficiente de aproveitamento de 2,03. São 7294 m2 de terreno, divididos em 09 lotes e com $14814 \mathrm{~m} 2$ de área total estimada de construção.

Nos lotes 01 e 02, cada um com uma metragem de $814 \mathrm{~m} 2$, onde serão construídas 2 torres, com 5 andares somando 15 metros de altura. O pavimento tipo é de $315 \mathrm{~m} 2$, perfazendo um total de $1575 \mathrm{~m} 2$ cada uma.

$\mathrm{O}$ recuo e os afastamentos são de $5 \mathrm{~m}$.

Nos lotes 03, 04, 05, 06, 07 e 08, cada um com uma metragem de 804 m2, onde serão construídas 6 torres, com 5 andares somando 15 metros de altura. O pavimento tipo é de $220 \mathrm{~m} 2$, perfazendo um total de $1100 \mathrm{~m} 2$ cada uma.

Para os lotes 03, 04 e 05, voltados para a avenida, o recuo é de $5 \mathrm{~m}$, sendo que os afastamento lateral é de $3 \mathrm{~m}$ e o afastamento de fundo é de $20 \mathrm{~m}$

Para os lotes 06,07 e 08 , voltados para a rua, o recuo é de $20 \mathrm{~m}$, sendo que os afastamento lateral é de $3 \mathrm{~m}$ e o afastamento de fundo é de $5 \mathrm{~m}$

No lote 09, com uma metragem de $1656 \mathrm{~m} 2$, onde será construída uma torre, com 12 andares somando 40 metros de altura. O pavimento tipo é de 422 $\mathrm{m} 2$, perfazendo um total de $5064 \mathrm{~m} 2$.

O recuo é de $5 \mathrm{~m}$, o afastamento lateral é de $3 \mathrm{~m}$ e o afastamento de fundo é de $5 \mathrm{~m}$.. 

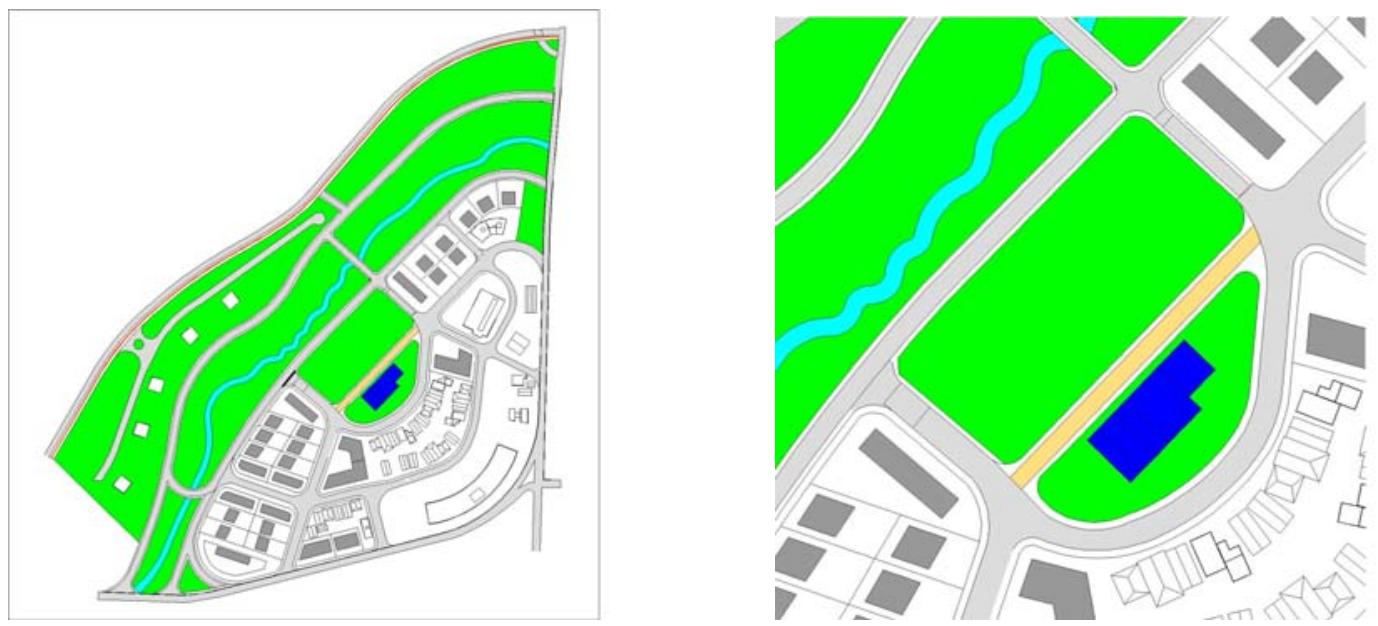

Imagem 114: Setor A - Ilustração da implantação da Praça e Zoom da Quadra da Praça
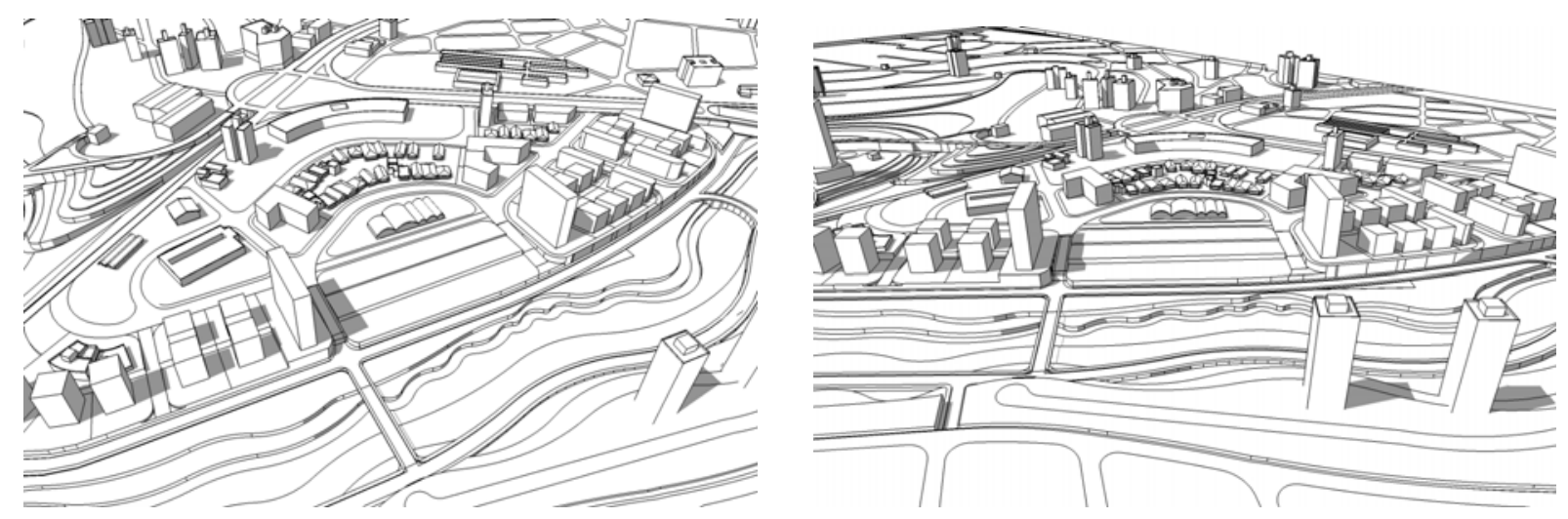

Imagem 115 e 116: Setor A - llustração da implantação da Praça

A Quadra da Praça, com 8856 m2, conforme explicado no Conceito Geral do Projeto Urbano Anhumas, é o espaço público que organiza a implantação das outras quadras, sendo que é também uma das peças chave da integração entre o tecido urbano das porções Sul (imediações da igreja Menino Jesus de Praga) e Norte (Taquaral - imediações da r. Paula Bueno), de modo a qualificar a intervenção como um todo. 


\section{QUADRA 03 - MEMORIAL CONCEITUAL}

$\mathrm{Na}$ quadra 03, conforme explicitado no texto referente à quadra 02, 0 edifício do lote 01 configura o vazio da Quadra da Praça e é de uso habitacional assim como as demais edificações.

Nos lotes 02, 0, 04 e 05 os edifícios configuram uma continuidade visual em relação ao volumes da quadra 04, contrapondo-se, como conjunto, ao vazio da Quadra da Praça.
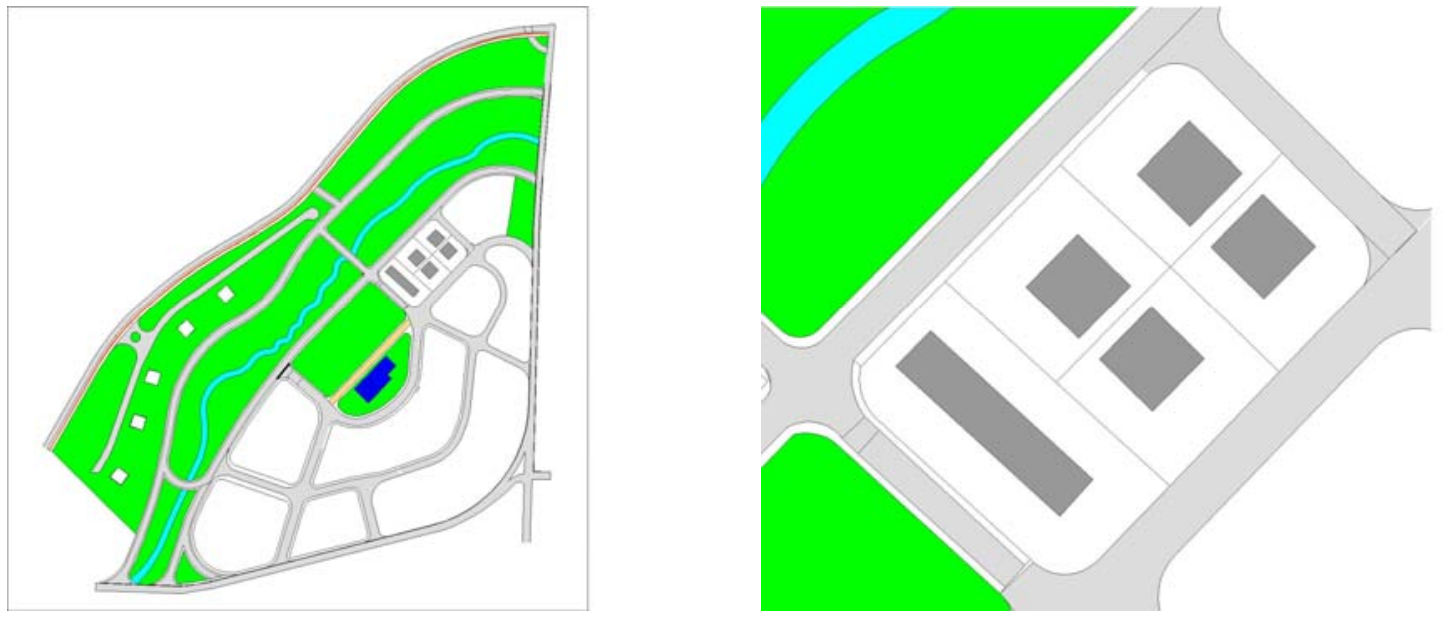

Imagem 117: Setor A - Quadra 03- Implantação Geral e Zoom

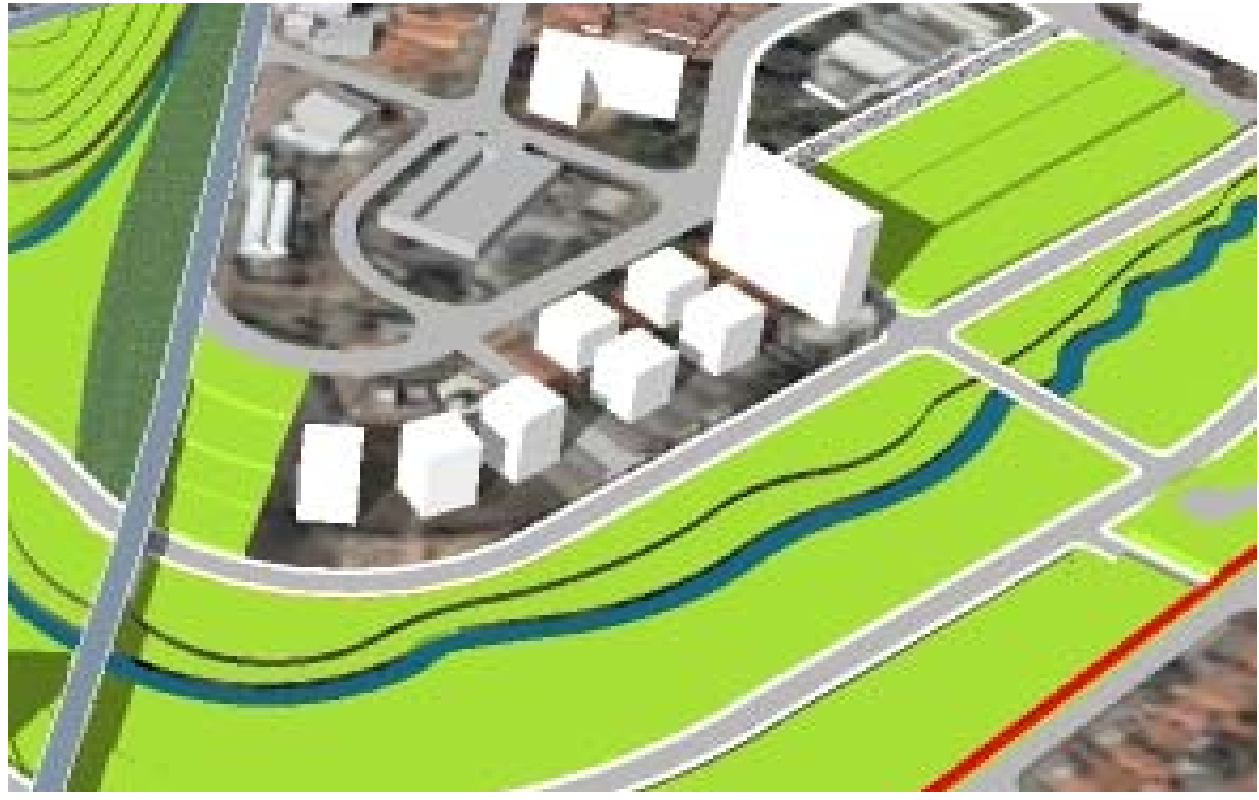

Imagem 118: Setor A - Quadra 04- Implantação Geral e Zoom 
QUADRA 03 - MEMORIAL DESCRITIVO

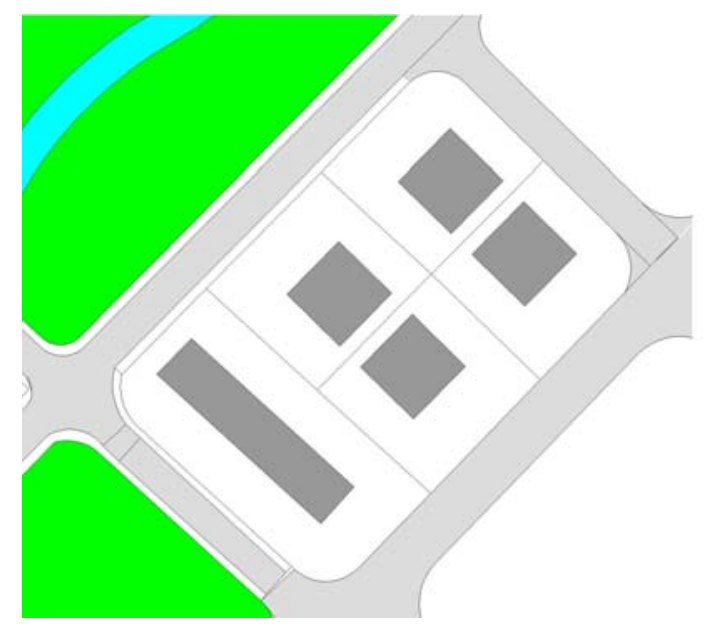

Imagem 119: Setor A - Quadra 03- Implantação Geral e Zoom

A Quadra 03, tem coeficiente de aproveitamento de 2,00. São $5840 \mathrm{~m} 2$ de terreno, divididos em 05 lotes e com 11664 m2 de área total estimada de construção.

No lote 01, com uma metragem de $1816 \mathrm{~m} 2$, onde será construída uma torre, com 12 andares somando 40 metros de altura. O pavimento tipo é de 447 $\mathrm{m} 2$, perfazendo um total de $5364 \mathrm{~m} 2$.

O recuo e o afastamento de fundo são de $10 \mathrm{~m}$, e o afastamento lateral é de $5 \mathrm{~m}$.

Nos lotes 02, 03, 04 e 05, cada um com uma metragem de 1006 m2, onde serão construídas 4 torres, com 7 andares somando 21 metros de altura. $\mathrm{O}$ pavimento tipo é de $225 \mathrm{~m} 2$, perfazendo um total de $1575 \mathrm{~m} 2$ cada uma.

O recuo é de $12 \mathrm{~m}$, sendo que o afastamento lateral é de $5 \mathrm{~m}$ e o afastamento de fundo é de $3 \mathrm{~m}$.

Os três edifícios propostos, voltados à Avenida Parque, de uso misto, configuram a continuidade volumétrica conforme descrito nos edifícios da quadra 03. 


\section{QUADRA 04 - MEMORIAL CONCEITUAL E DESCRITIVO}

Os três edifícios propostos, voltados à Avenida Parque, de uso misto, configuram a continuidade volumétrica conforme descrito nos edifícios da quadra 03.
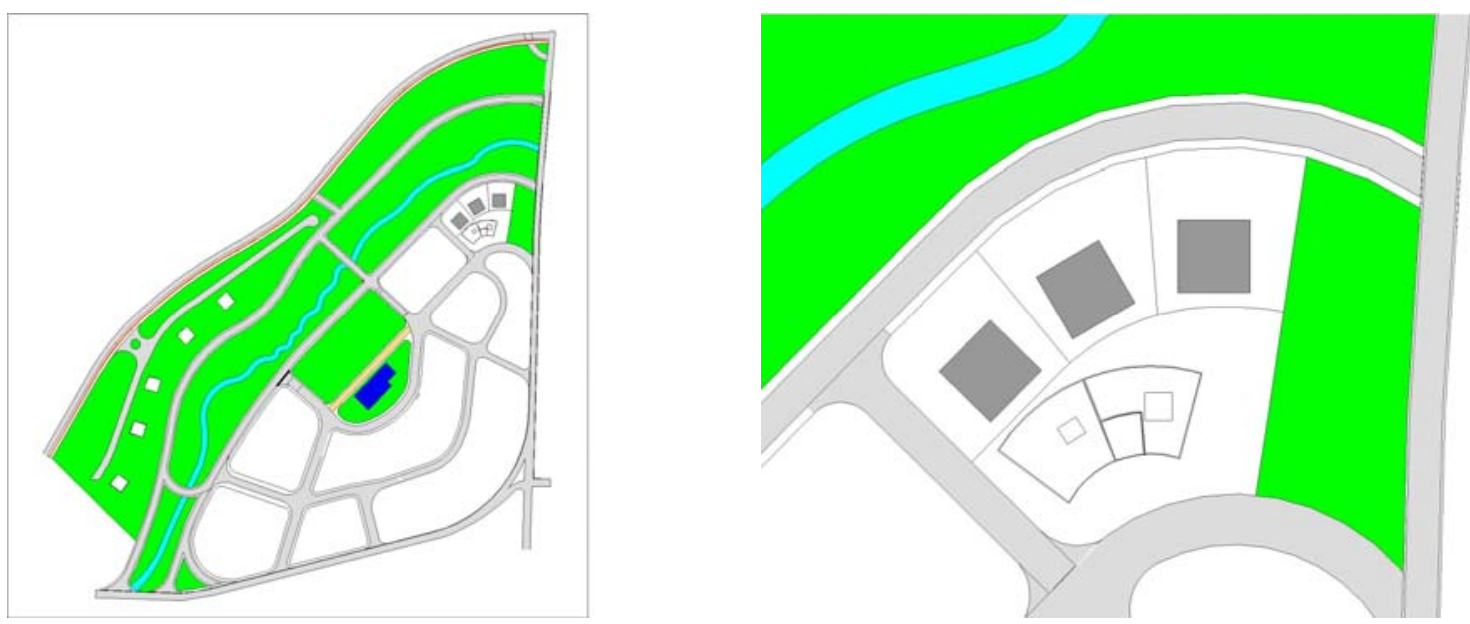

Imagem 120: Setor A - Quadra 04- Implantação Geral e Zoom

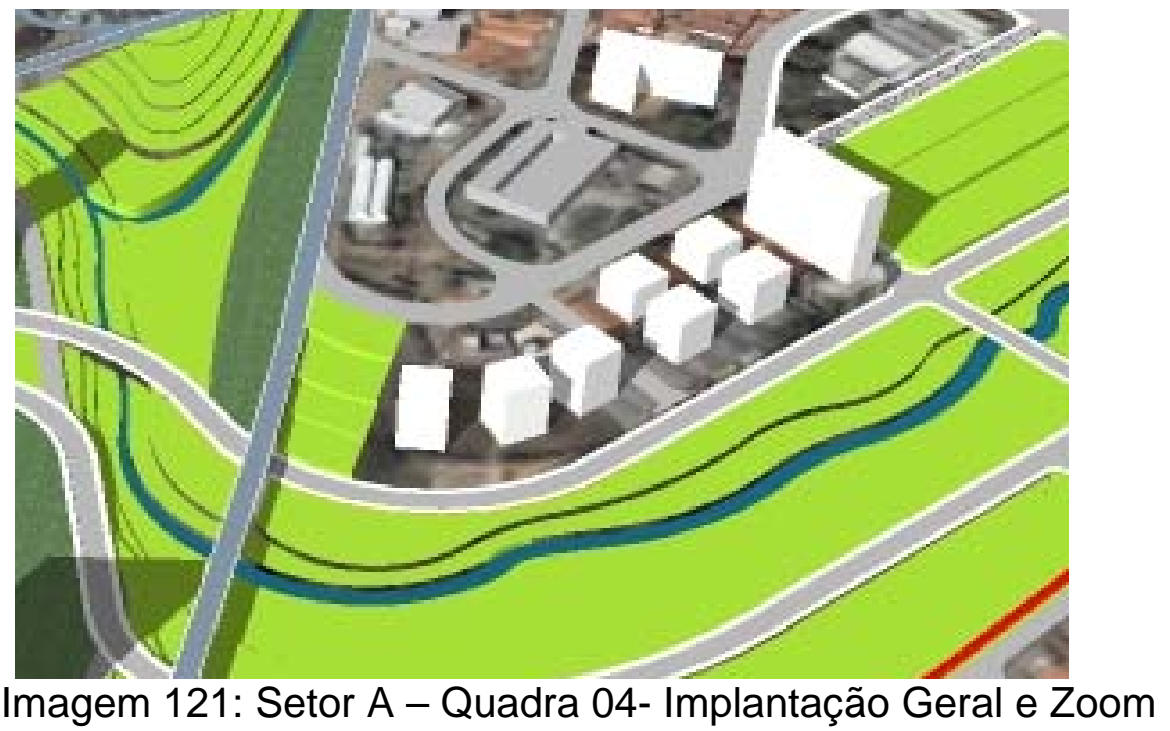

A Quadra 04, tem coeficiente de aproveitamento de 1,97. São 2742 m2 de terreno, divididos em 03 lotes e com 5400 m2 de área total estimada de construção.

Nos lotes 01, 02 e 03, cada um com uma metragem de 914 m2, onde serão construídas 3 torres, com 8 andares somando 25 metros de altura. 0 pavimento tipo é de $225 \mathrm{~m} 2$, perfazendo um total de $1800 \mathrm{~m} 2$ cada uma.

O recuo é de $12 \mathrm{~m}$, sendo que o afastamento lateral é de $5 \mathrm{~m}$ e o afastamento de fundo é de $3 \mathrm{~m}$. 


\section{QUADRA 05 - LOTE 5A - MEMORIAL CONCEITUAL}

No lote 5A, a edificação de uso misto, configura-se como definidora do largo, descrito pela noção de percurso apresentada na Quadra 02.

Este lote foi criado com a desativação de uma rua existente, visando melhorar o sistema viário local e reforçar o desenho concêntrico pré- existente.
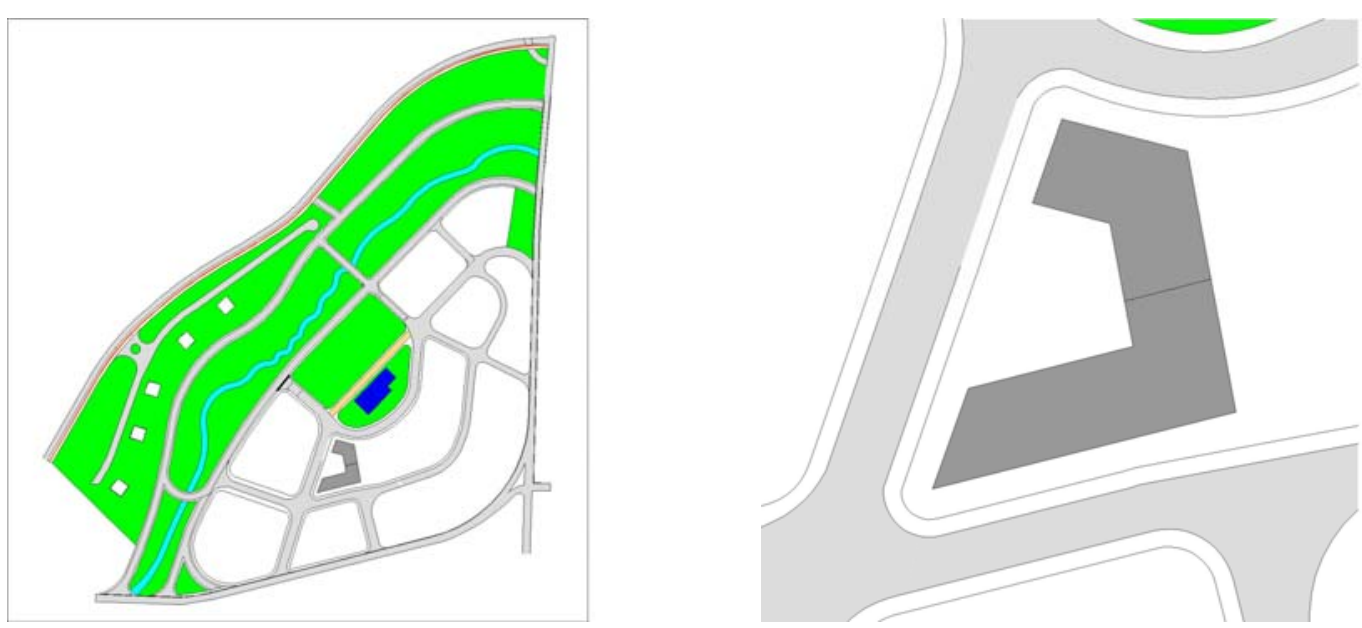

Imagem 00 e 00: Setor A - Quadra 05A- Implantação Geral e Zoom

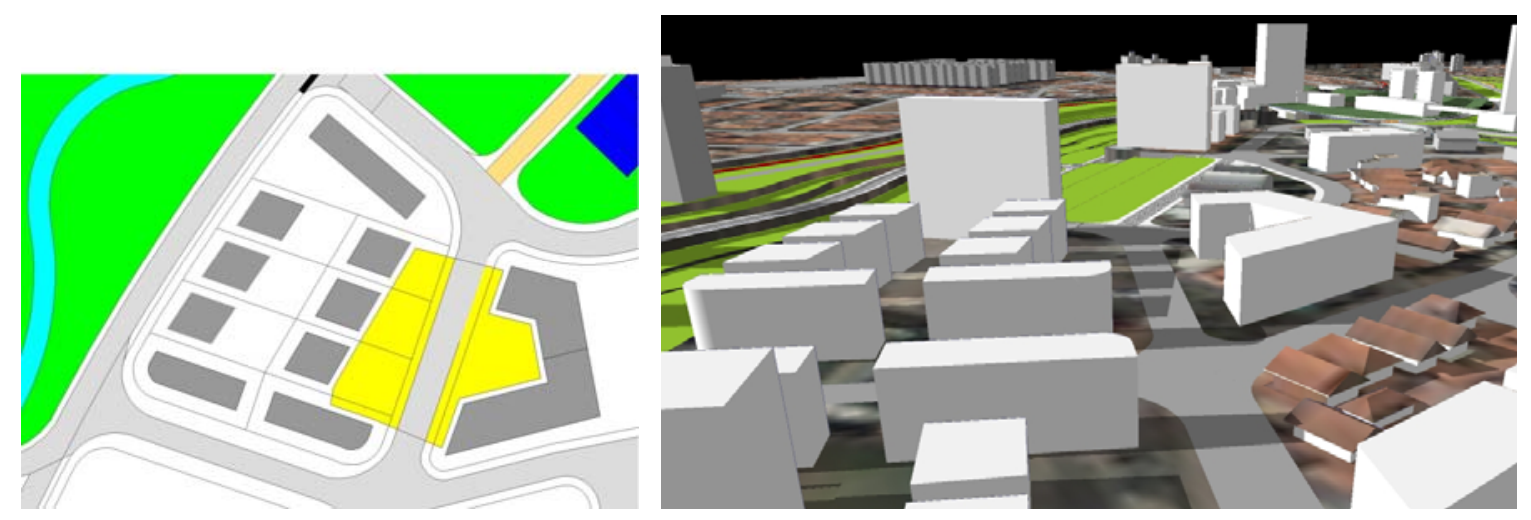

Imagem 122 e 123: Setor A - Quadra 05A - Relação Urbana com Quadra 02 em planta e em vista 


\section{QUADRA 05 - LOTE 5A - MEMORIAL DESCRITIVO}

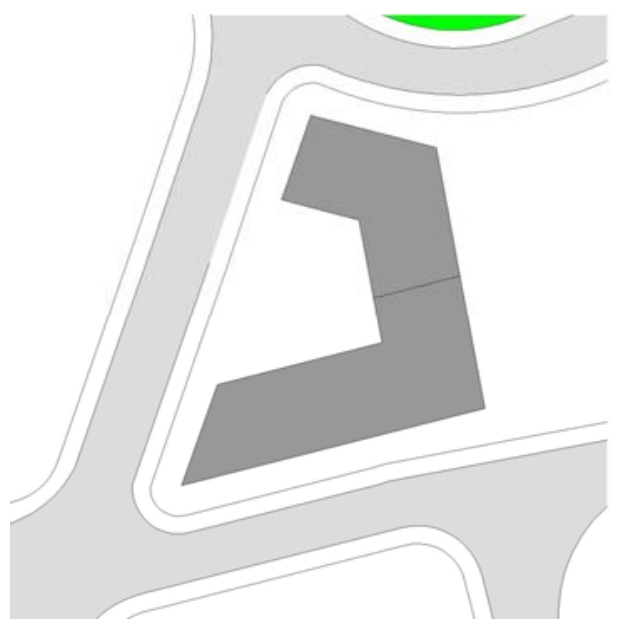

Imagem 124: Setor A - Quadra 05A- Implantação

A Quadra 05, tem coeficiente de aproveitamento de 1,85. São 4487 m2 de terreno, divididos em 02 lotes e com 8295 m2 de área total estimada de construção.

No lote $5 \mathrm{~A}$, com uma metragem de $2411 \mathrm{~m} 2$, onde será construída um edifício com 5 andares somando 15 metros de altura. O pavimento tipo é de $841 \mathrm{~m} 2$, perfazendo um total de $4205 \mathrm{~m} 2$.

O recuo e os afastamentos são de $5 \mathrm{~m}$.

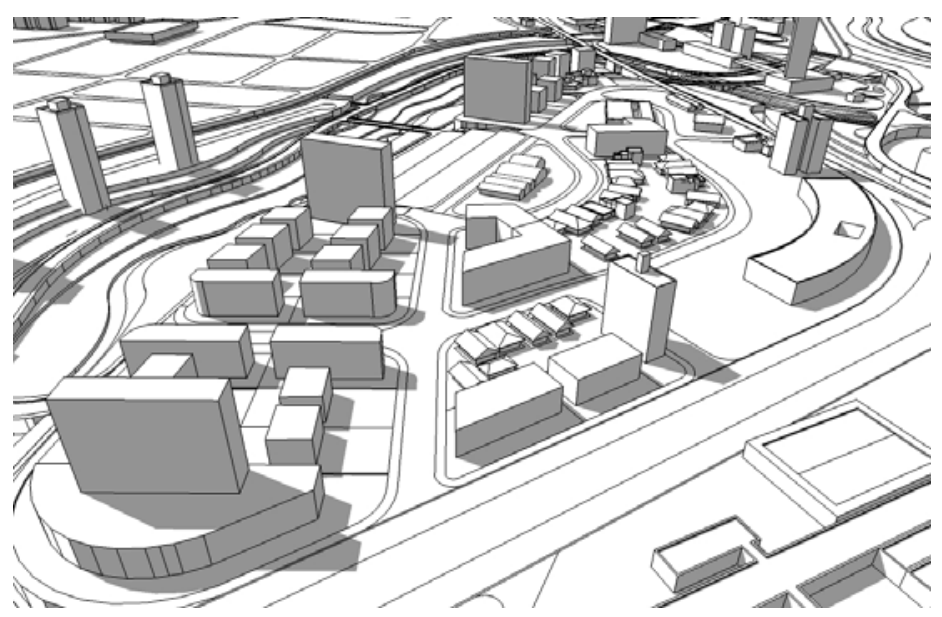

Imagem 125: Setor A - Vista Geral 


\section{QUADRA 05 - LOTE 5B - MEMORIAL CONCEITUAL E DESCRITIVO}

No lote 5B, a edificação de uso misto está implantada de forma a valorizar a volumetria das edificações do entorno, e ao mesmo tempo cria um espaço livre para a integração entre o lote 5B e o lote da Igreja Menino Jesus de Praga e a Quadra da Praça.
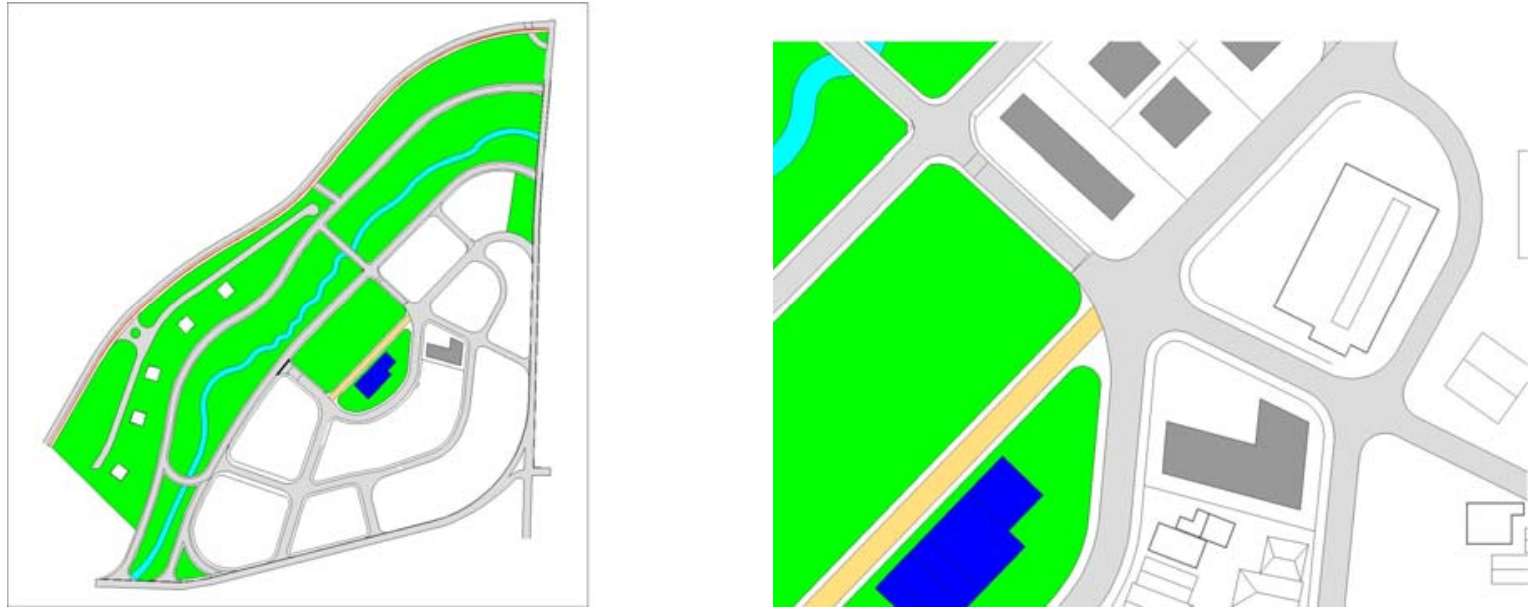

Imagem 126 e 127: Setor A - Quadra 05 Lote 5B - Relação Urbana com Quadra 04, a praça e a Igreja(em azul).

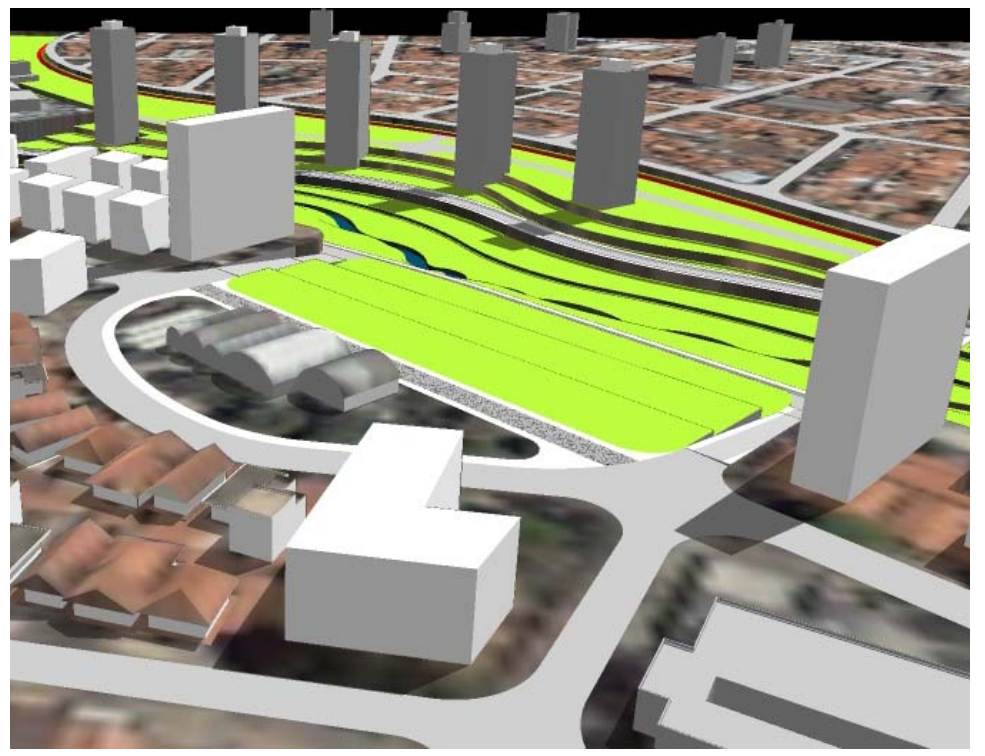

Imagem 128: Quadra 05 Lote 5B - Volumetria da relação urbana com Quadra 04, a praça e da Igreja.

No lote 5B, com uma metragem de $2.076 \mathrm{~m} 2$, onde será construída um edifício com 5 andares somando 15 metros de altura. O pavimento tipo é de 818 m2, perfazendo um total de $4090 \mathrm{~m} 2$. O recuo e o afastamento são de $5 \mathrm{~m}$. 


\section{QUADRA 06 - MEMORIAL CONCEITUAL E DESCRITIVO}

Na quadra 06, os edifícios estão alinhadaos à avenida orozimbo maia, e tem como uso previsto, o uso comercial. Com gabarito baixo, reforçam a integração da volumetria proposta ao entorno do bairro existente.
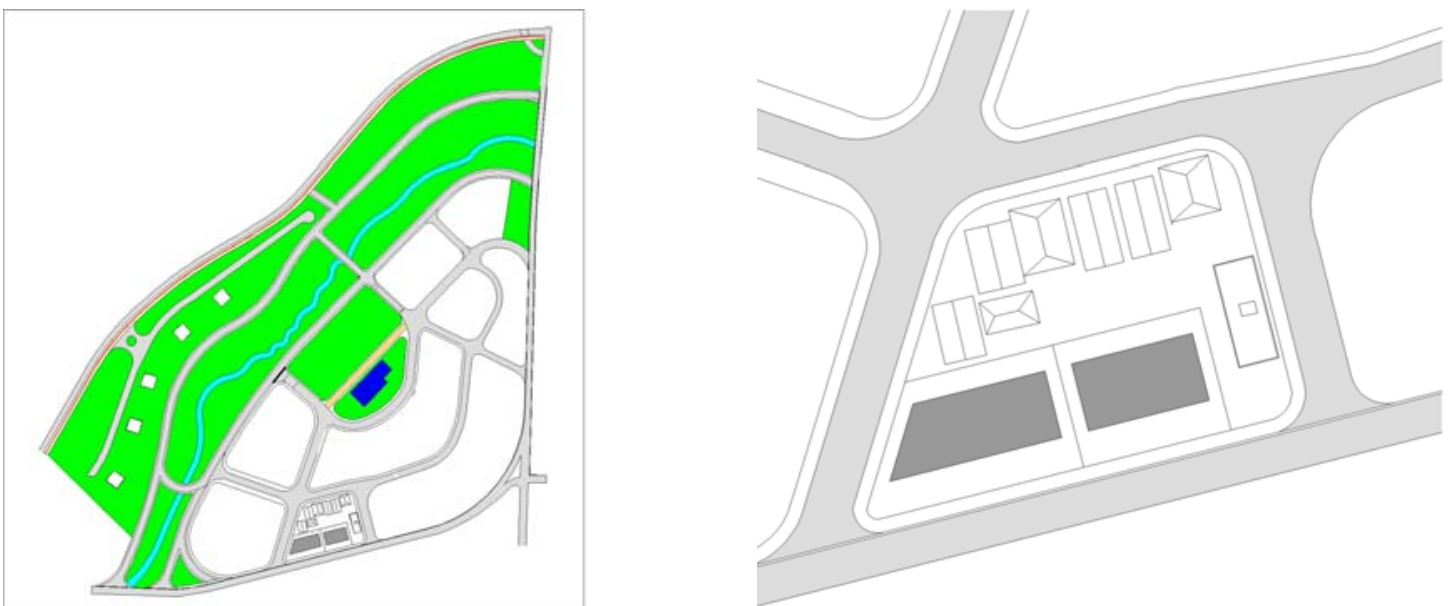

Imagem 129 e 130: Setor A - Quadra 06 - Implantação Geral e Zoom.

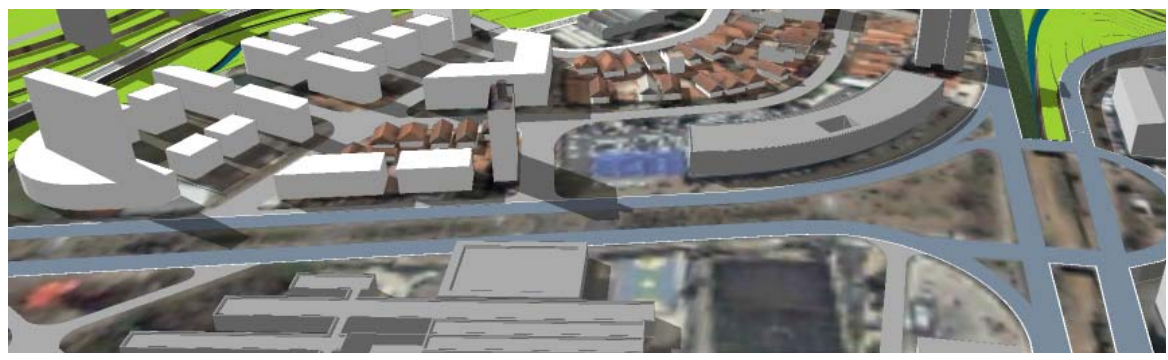

Imagem 131 : Setor A - Quadra 06 - Vista geral do contexto

A Quadra 06, tem coeficiente de aproveitamento de 1,80. São 2042 m2 de terreno, divididos em 02 lotes e com 3672 m2 de área total estimada de construção.

No lote 01, com uma metragem de 1133 m2, onde será construída um edifício com 4 andares somando 12 metros de altura. O pavimento tipo é de $512 \mathrm{~m} 2$, perfazendo um total de $2048 \mathrm{~m} 2$.

O recuo é de $7 \mathrm{~m}$, sendo que o afastamento lateral é de $3 \mathrm{~m}$ e o afastamento de fundo é de $5 \mathrm{~m}$.

No lote 02, com uma metragem de 909 m2, onde será construída um edifício com 4 andares somando 12 metros de altura. O pavimento tipo é de $406 \mathrm{~m} 2$, perfazendo um total de $1624 \mathrm{~m} 2$.

O recuo é de $7 \mathrm{~m}$, sendo que o afastamento lateral é de $3 \mathrm{~m}$ e o afastamento de fundo é de $5 \mathrm{~m}$. 


\section{SETOR B - MEMORIAL CONCEITUAL}

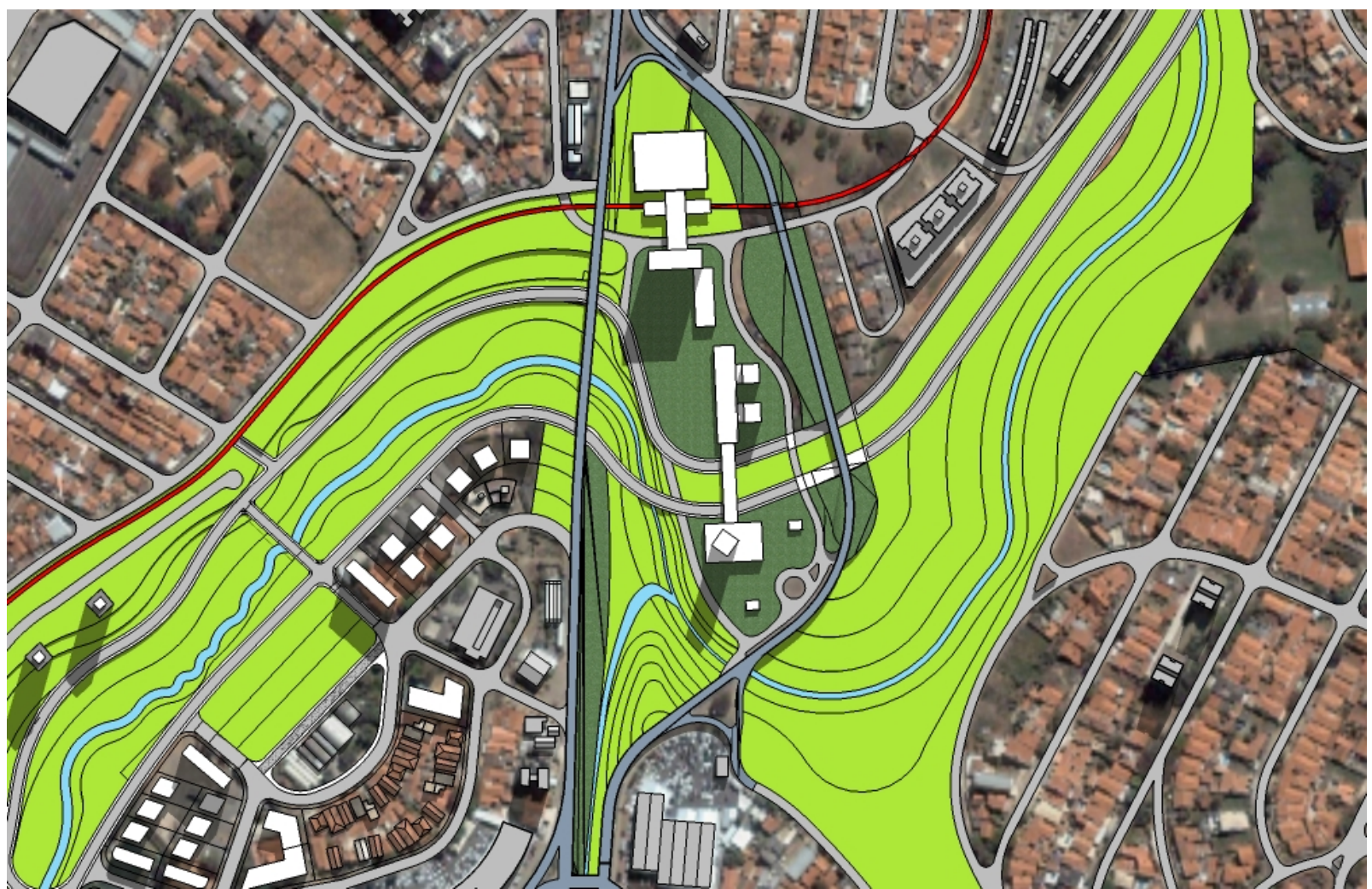

Imagem 132: Setor B - Implantação.

No Setor B, estamos enfatizando a articulação entre diferentes escalas do Projeto Urbano, seja local ou a escala metropolitana do Parque Linear e dos fluxos regionais articulados pela Estação Intermodal e a Avenida Parque, mediados pela área livre, que percorre a proposta como um todo.

Dada as condições do entorno, como as alças dos viadutos, elevadas, e já configuradas anteriormente como barreiras físicas e visuais, o partido adotado foi a ocupação com baixo índice de aproveitamento, possibilitando que o Parque Linear permeie todas a quadras do setor. Este baixo coeficiente permite a criar a integração visual das glebas, apesar de serem seccionadas tanto pela Avenida Parque como pelo leito ferroviário. Desse modo, os fragmentos urbanos compõe um novo tecido urbano que passa a se integrar à cidade, não mais como espaços residuais. 


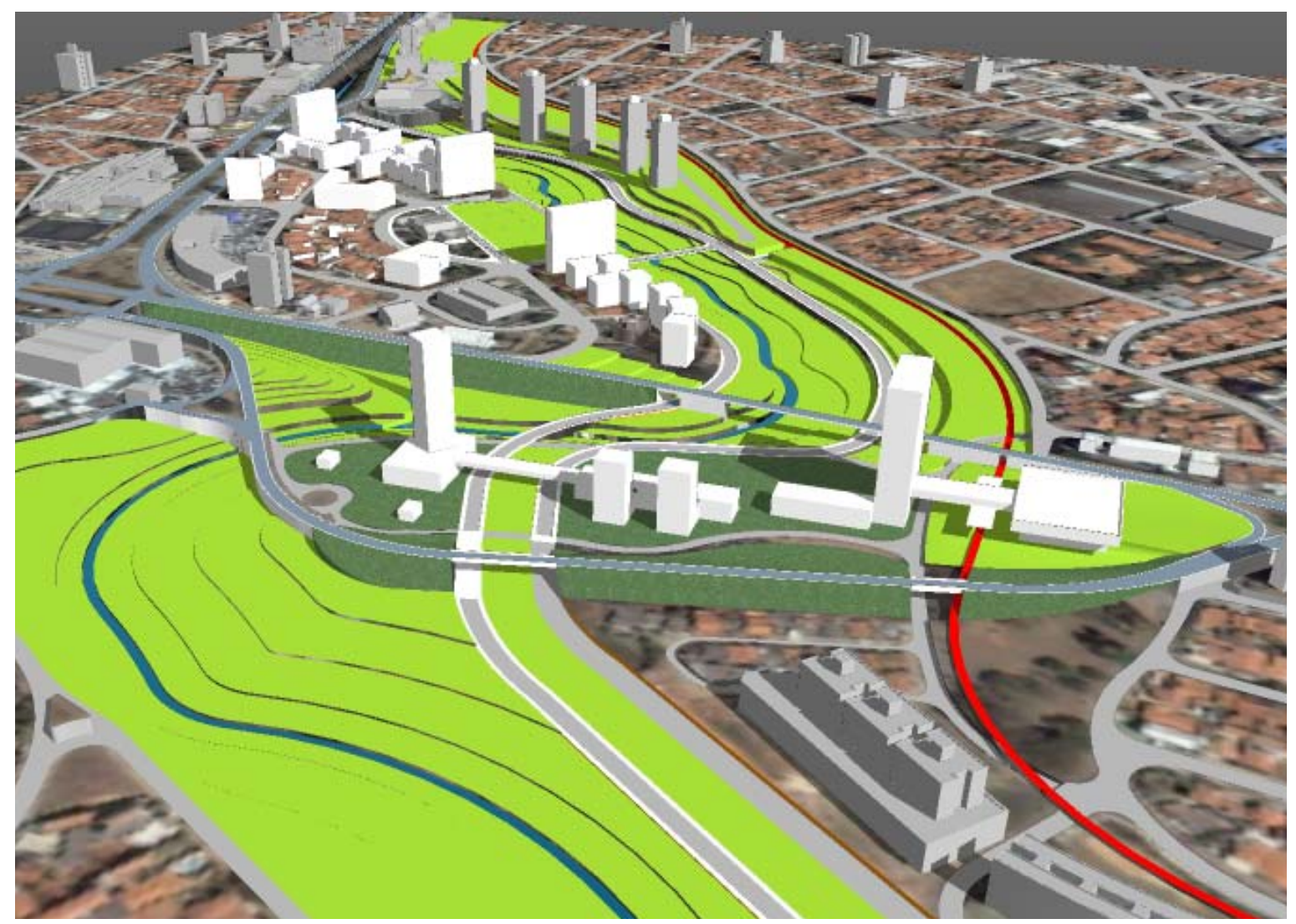

Imagem 133: Setor B - Vista geral com o Centro de Negócios como elemento articulador entre a Estação Intermodal e o Centro de Exposições

As novas funções de caráter regional propostas, como Centro de Negócios, Centro de Eventos e Hotel, são resultados das condições de acessibilidade já mencionadas. A verticalização do programa pretende atender as premissas dos coeficientes já citados, e atendem à outra importante função: criar um conjunto marco referencial como marco na paisagem, de modo a aumentar o interesse da iniciativa privada, articulando e ampliando, assim, a composição dos interessados no Projeto Urbano Anhumas. 


\section{SETOR B - MEMORIAL DESCRITIVO}
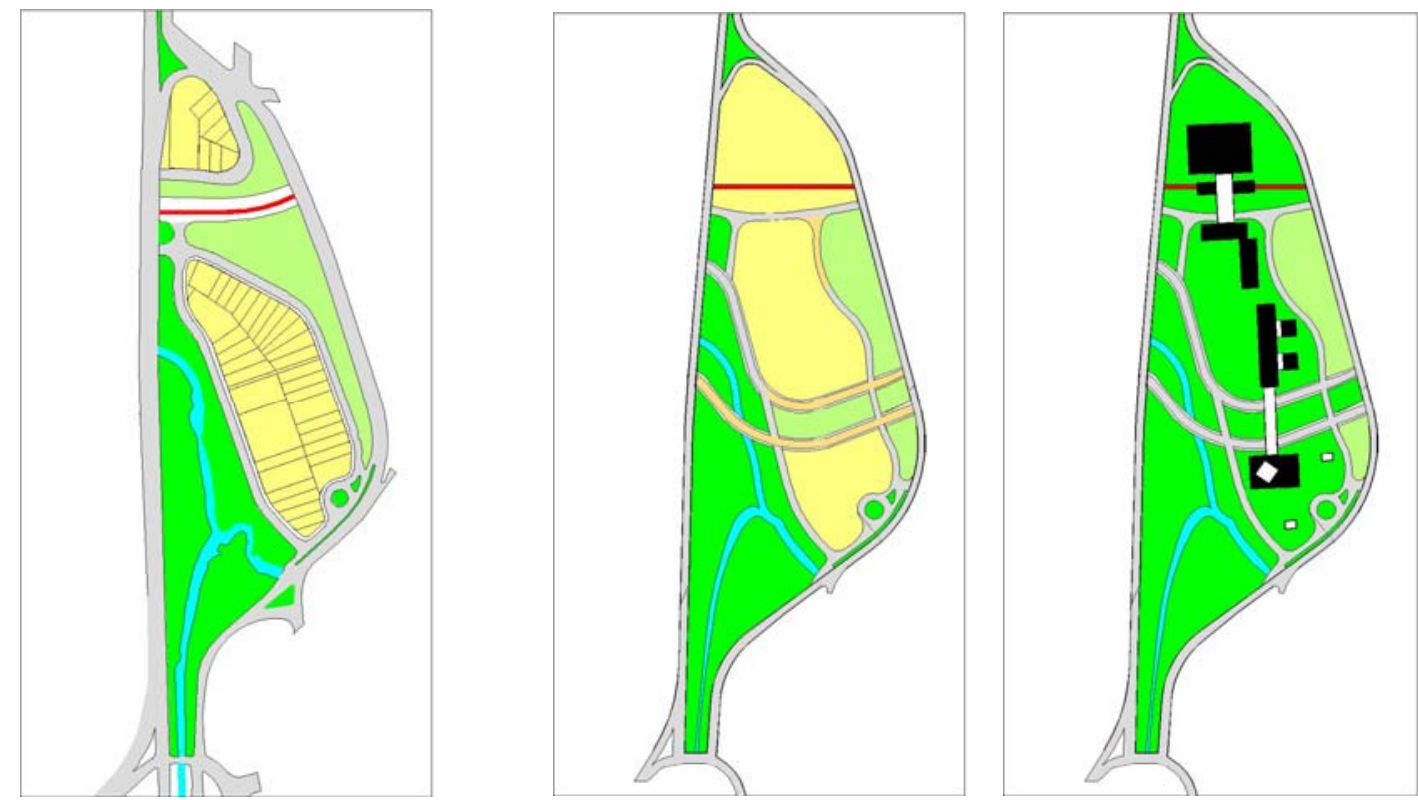

Imagem 134 e 135: Setor B - Situação Existente, novo viário e Proposta.

O Setor B, com área total de $91.407 \mathrm{~m} 2$, destina $14.622 \mathrm{~m} 2$ para o sistema viário estrutural existente.

As áreas verdes ocupam grande proporção do setor e são sudividas em:

O trecho da formação do ribeirão Anhumas, situado ao sul do setor, tem área de $21.356 \mathrm{~m} 2$.

AS áreas das áreas verdes, são:

Fragmento A, com 1043 m2, situado ao Sul do setor, Fragmento B, com $5.287 \mathrm{~m} 2$, situado a leste do setor e Fragmento C, com $735 \mathrm{~m} 2$ e situado a oeste do setor.

A continuação da Avenida Parque e do seu canteiro central, que se configura como parque do Parque Linear, ocupa $12.637 \mathrm{~m} 2$

O Sistema viário entre estas áreas e as quadras redesenhadas possui $3.902 \mathrm{~m} 2$.

O local das intervenções edificadas, possui $31.825 \mathrm{~m} 2$ de área, divididos em 03 quadras. São previstos 42.409 m2 de área total a ser construída, com coeficientes de aproveitamento variantes de 0,91 a 1,80. 


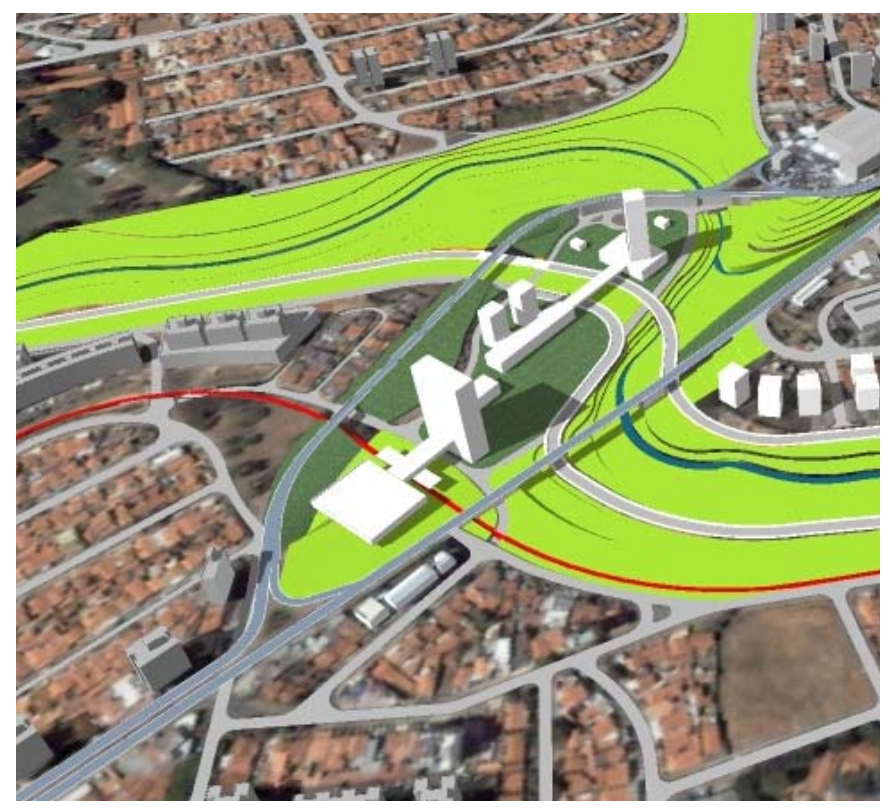

Imagem 136: Setor B - Situação Volumétrica Proposta em vista.

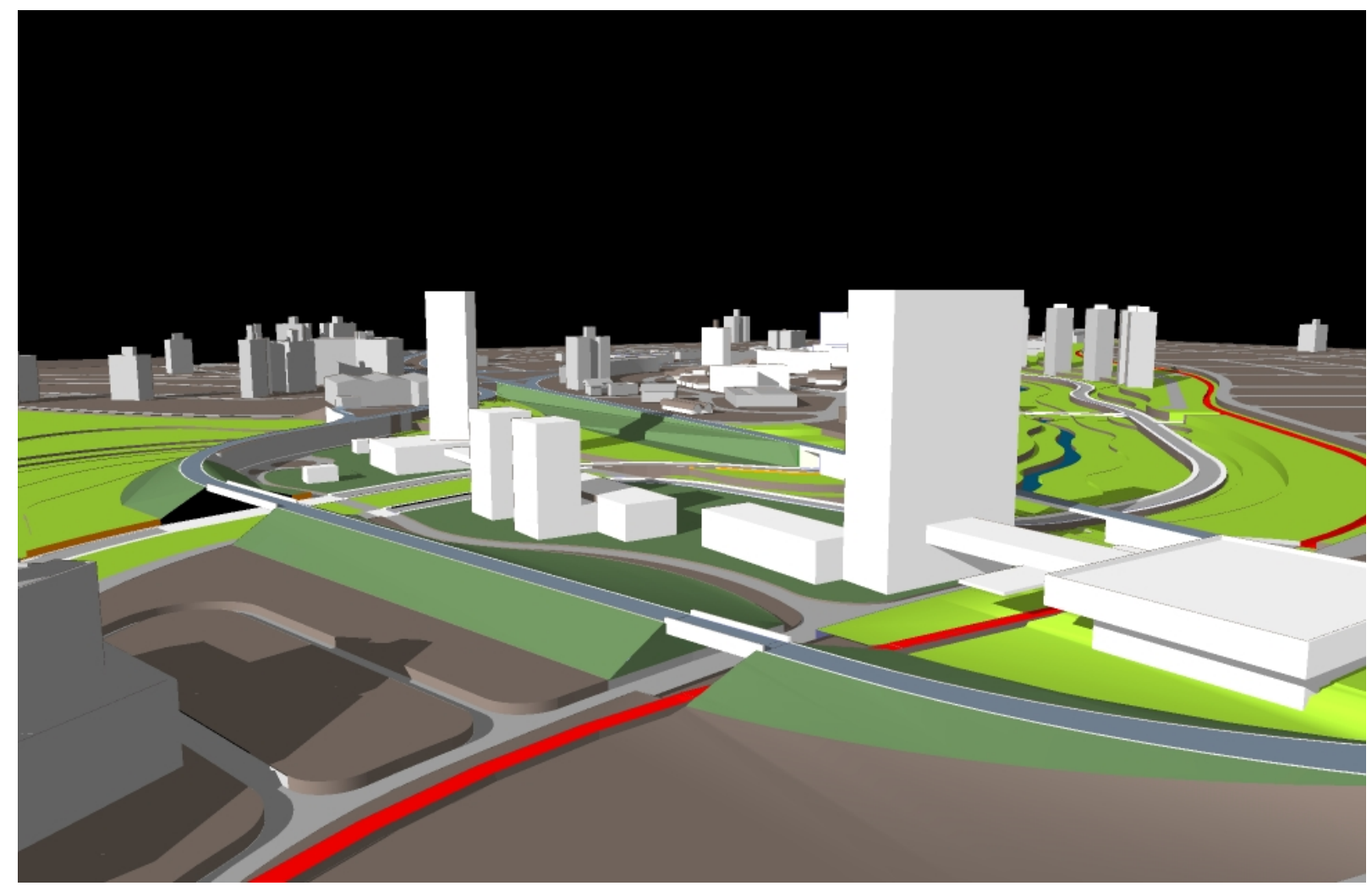

Imagem 137: Setor B - Vista Geral. 
QUADRA DA ESTACAO INTERMODAL - MEMORIAL CONCEITUAL
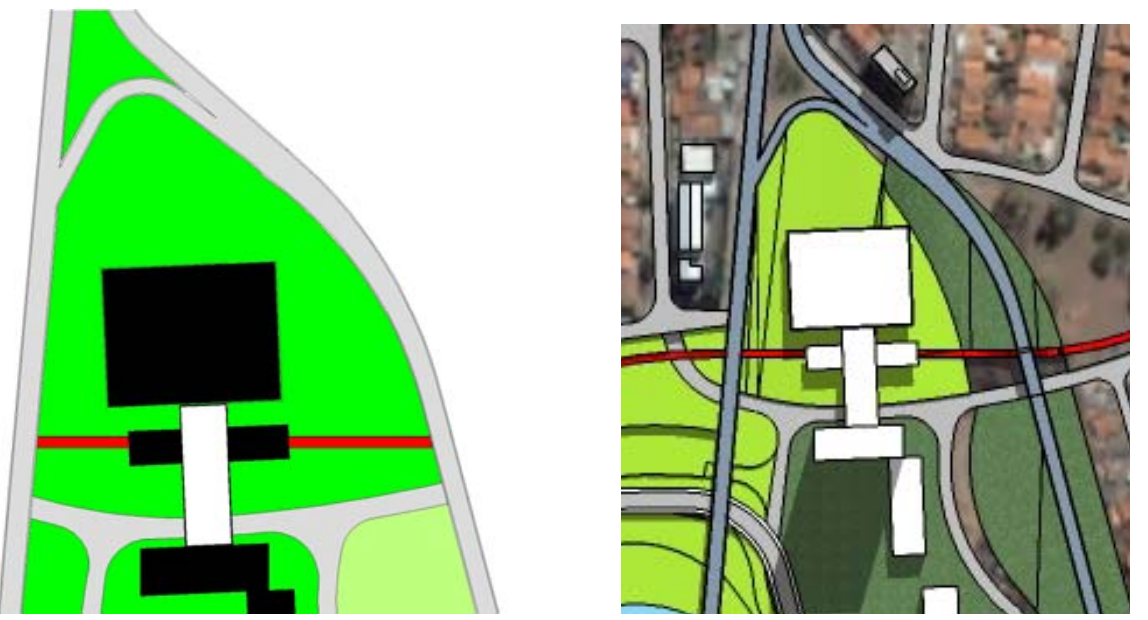

Imagem 138: Setor B - Zoom da proposta da Estação Intermodal.

A existência do desnível topográfico junto à ferrovia, no trecho norte da área, foi o fator decisivo para a o posicionamento de uma nova Estação Intermodal para a região, possibilitando o uso da acessibilidade viária local existente e o acesso do pedestre em diferentes níveis. Esta articulação dos níveis permite que um usuário possa transpor as barreiras urbanas, como trem ou a avenida.

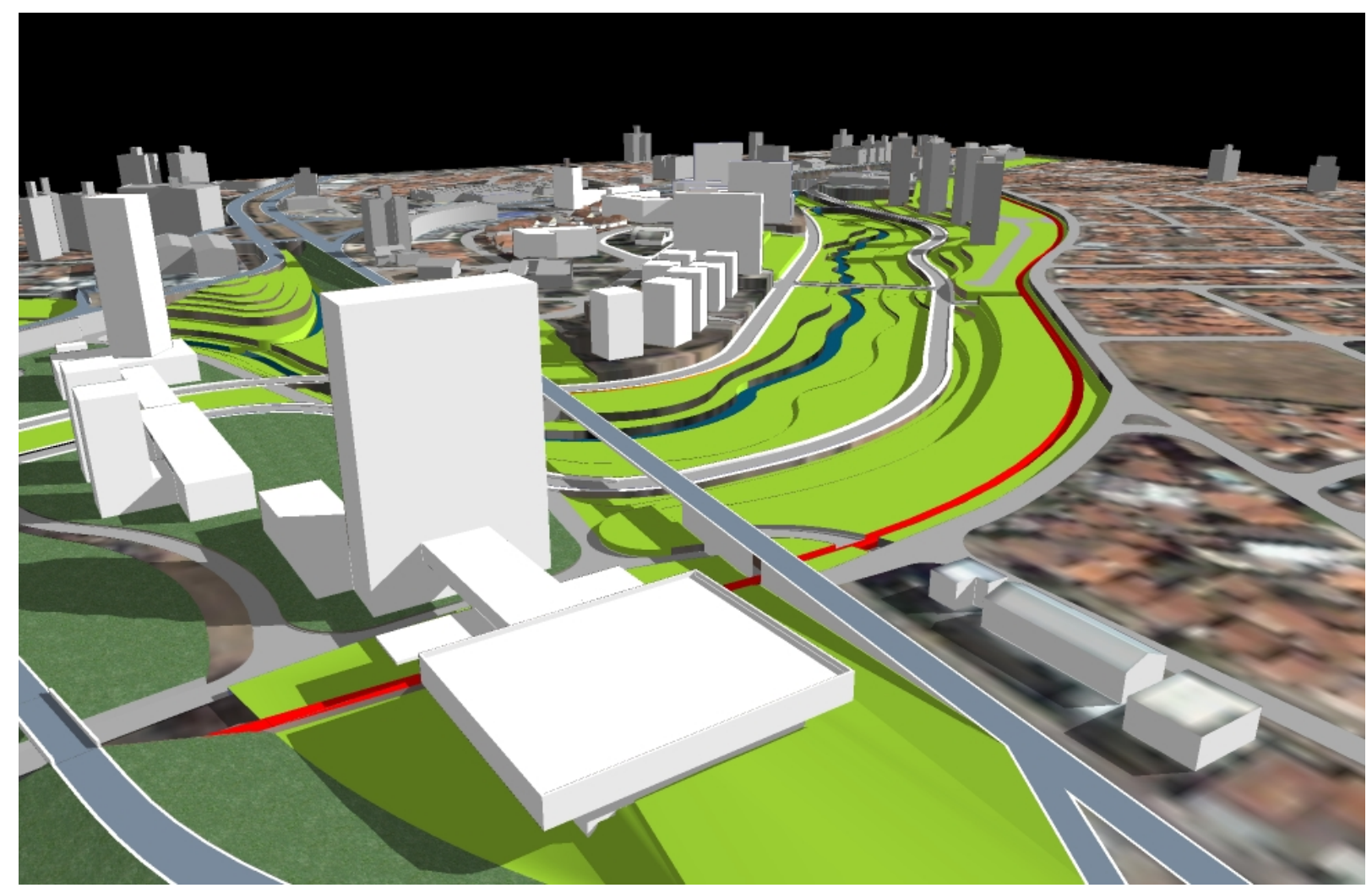

Imagem 139: Setor B - Proposta da Estação Intermodal. 


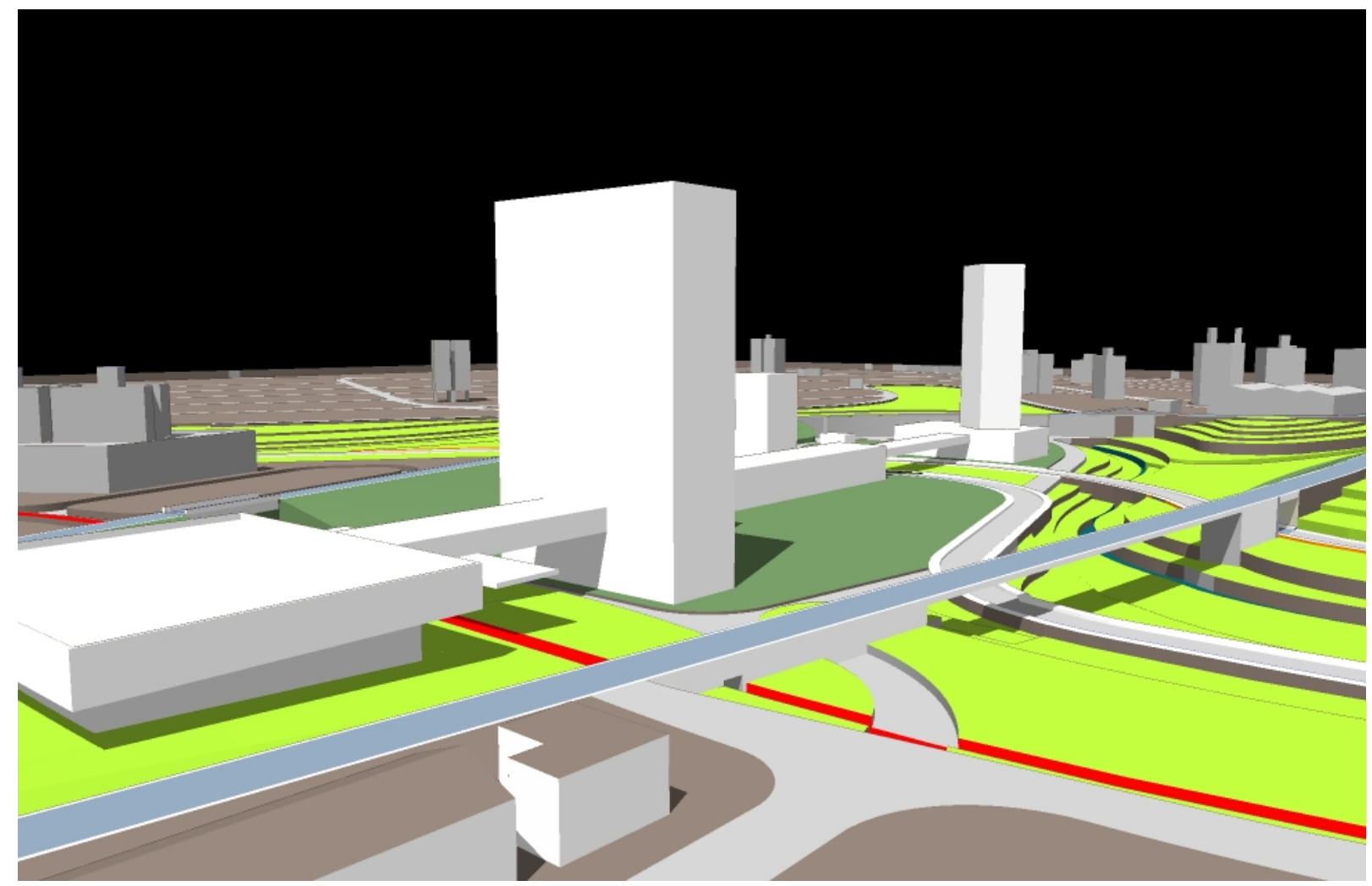

Imagem 140: Setor B - Zoom da proposta da Estação Intermodal aproveitando os desníveis existentes do terreno de modo a organizar a acessibilidade e as diferentes funções .

A cobertura da plataforma de embarque é situada ao longo dos trilhos e esta situada paralelamente ao Edifício de Serviços do Centro de Negócios, na quadra ao lado. Esta implantação define um trecho de rua com características de espaço "entre", configurado de modo a marcar claramente o acesso, tanto do Edifício quanto da Estação. Este Edifício de Serviços também é integrado à Quadra da Estação pela Conexão, que se trata de uma passarela elevada, suspensa 8 metros da rua, de modo a fazer com que o pedestre transponha, em outro nível, a rua de acesso. 


\section{QUADRA DA ESTAÇÃO INTERMODAL - MEMORIAL DESCRITIVO}

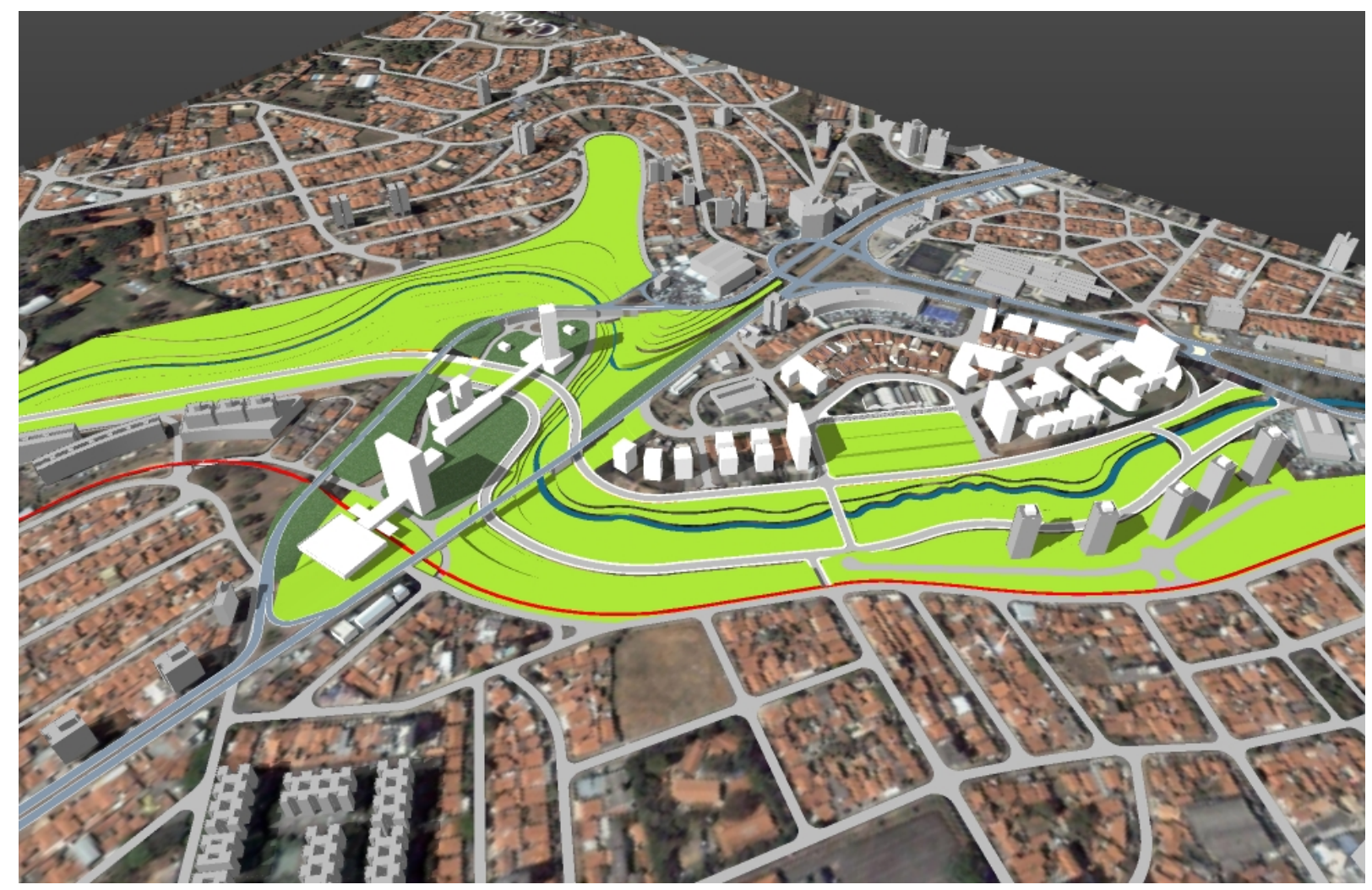

Imagem 141: Setor B - Zoom da proposta da Estação Intermodal no contexto geral.

A Quadra da Estação, tem coeficiente de aproveitamento de 1,06. São $12.621 \mathrm{~m} 2$ de terreno e $13.371 \mathrm{~m} 2$ de área total estimada de construção, divididos em 3 edificações.

A Estação Intermodal, com 5 andares somando $15 \mathrm{~m}$ de altura, tem 0 pavimento tipo de $2.462 \mathrm{~m} 2$ perfazendo um total de $12.310 \mathrm{~m} 2$.

A Cobertura de Embarque, com 2 andares somando $6 \mathrm{~m}$ de altura, tem o pavimento tipo de $185 \mathrm{~m} 2$, perfazendo um total de $370 \mathrm{~m} 2$.

A Conexão, com um andar somando 03 m de altura, tem 691 m2 de área total. 


\section{QUADRA DO CENTRO DE NEGÓCIOS - MEMORIAL CONCEITUAL}
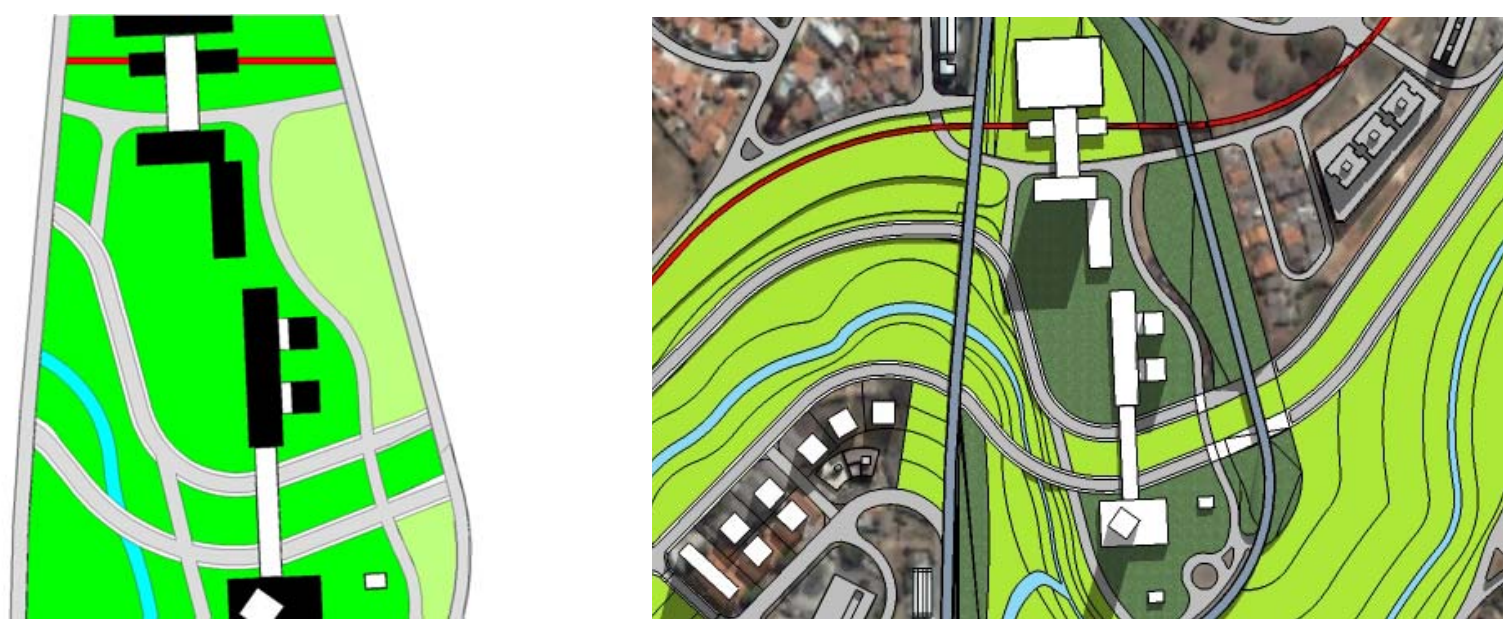

Imagem 142: Setor B - Zoom da proposta de Centro de Exposições.

A implantação dos edifícios da Quadra do Centro de Negócios cria uma praça retangular livre, definida por elementos construídos em duas das suas bordas, valorizando o impacto visual do Edifício de Serviços. Este edifício, conforme descrito na Quadra da Estação, se articula com a Estação Intermodal por passarela suspensa em relação ao nível da rua. Volumetricamente funciona como contraponto ao vazio da área livre proposta, e está conectado às outras duas Torres de Escritórios ( $\mathrm{A}$ e B) pelo percurso interno entre o Edifício Anexo e o Edifício Lâmina, ambos alinhados, formando um eixo construído. Este corpo linear vincula-se à rua pelo alinhamento, valorizando-a, ao mesmo tempo em que é borda edificada da área livre, no interior quadra, configurada como praça.

O Edifício Lâmina foi pensado para atender, na macro escala de projeto da quadra, o papel de espaço de transição entre o interior da quadra e a rua de acesso. Esta implantação sugere, entre outros, a instalação de um estabelecimento comercial - restaurante - no térreo, permitindo tirar partido da visibilidade da praça interna. Na micro escala, articula os fluxos de acesso entre os edifícios da quadra e o hall de acesso das duas Torres de Escritório (A e B) que estão destacadas do bloco, ganhando expressividade volumétrica por seu maior gabarito. 


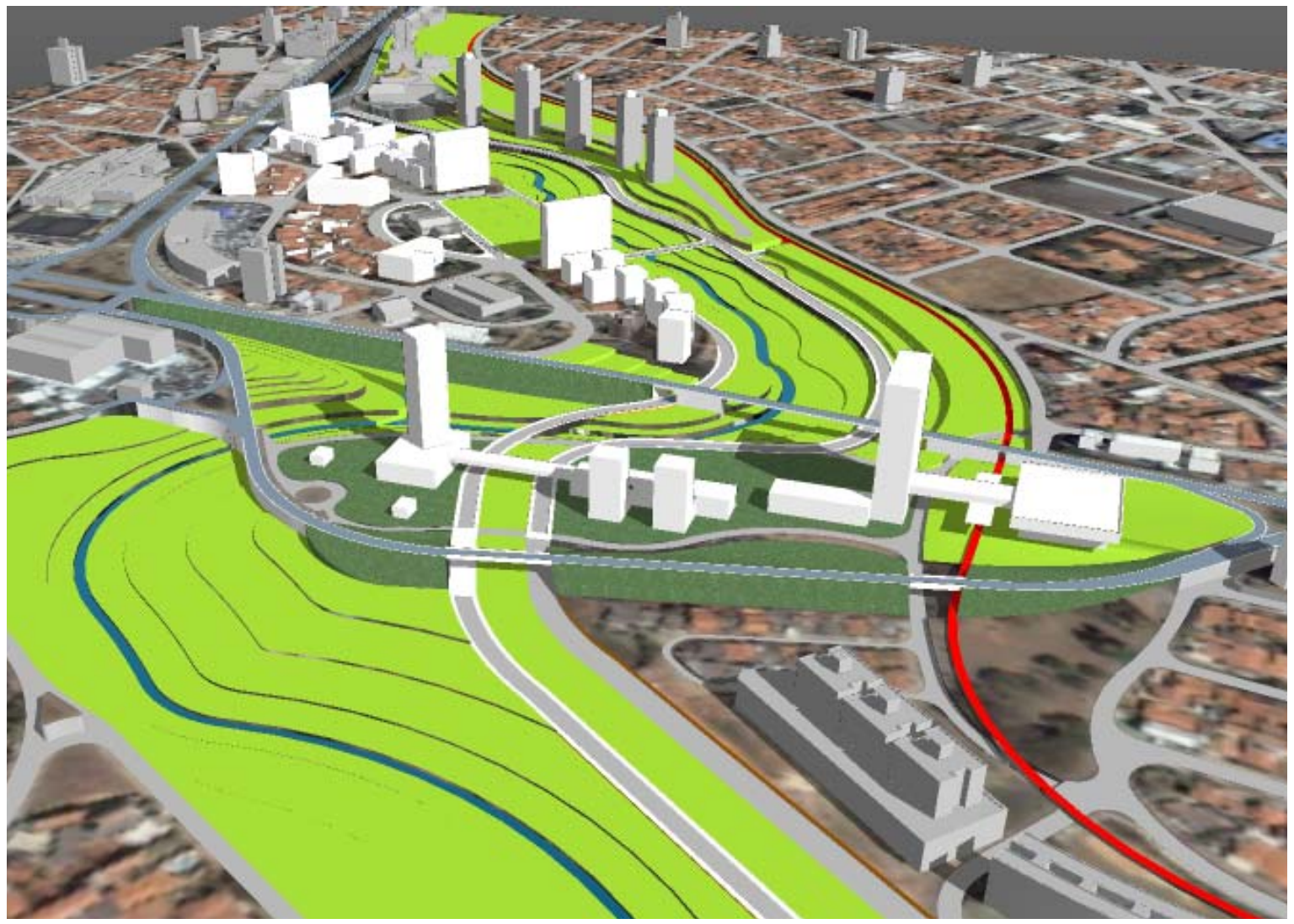

Imagem 143: Setor B - Vista geral com o Centro de Negócios como elemento articulador entre a Estação Intermodal e o Centro de Eventos.

O papel da área livre, definida pela implantação do conjunto de edificações da Quadra de Negócios é integrar a Quadra ao entorno, também configurado como área Parque Linear. A praça é elemento chave da integração entre as quadras do Setor $B$, pois, além do seu caráter paisagístico, pode ser parcialmente ocupada como superfície plana em eventos temporários, acessos e estacionamento.

A Edificação que possibilita ao pedestre transpor a Avenida Parque é a Conexão entre o Edifício Lâmina e o Centro de Eventos, situada à 8 metros de altura em relação à Avenida Parque. Além da função de ligação, este edifício potencialmente poderá abrigar outros usos, como comércio, ou como acesso ao Parque Linear, para que o pedestre possa percorrer a área livre do canteiro central de modo a desfrutar do Parque Linear sem que haja contato com o fluxo de veículos. Vale lembrar que o canteiro central poderá abrigar diversas funções de apoio como quiosques e equipamentos de lazer. 


\section{QUADRA DO CENTRO DE NEGÓCIOS - MEMORIAL DESCRITIVO}

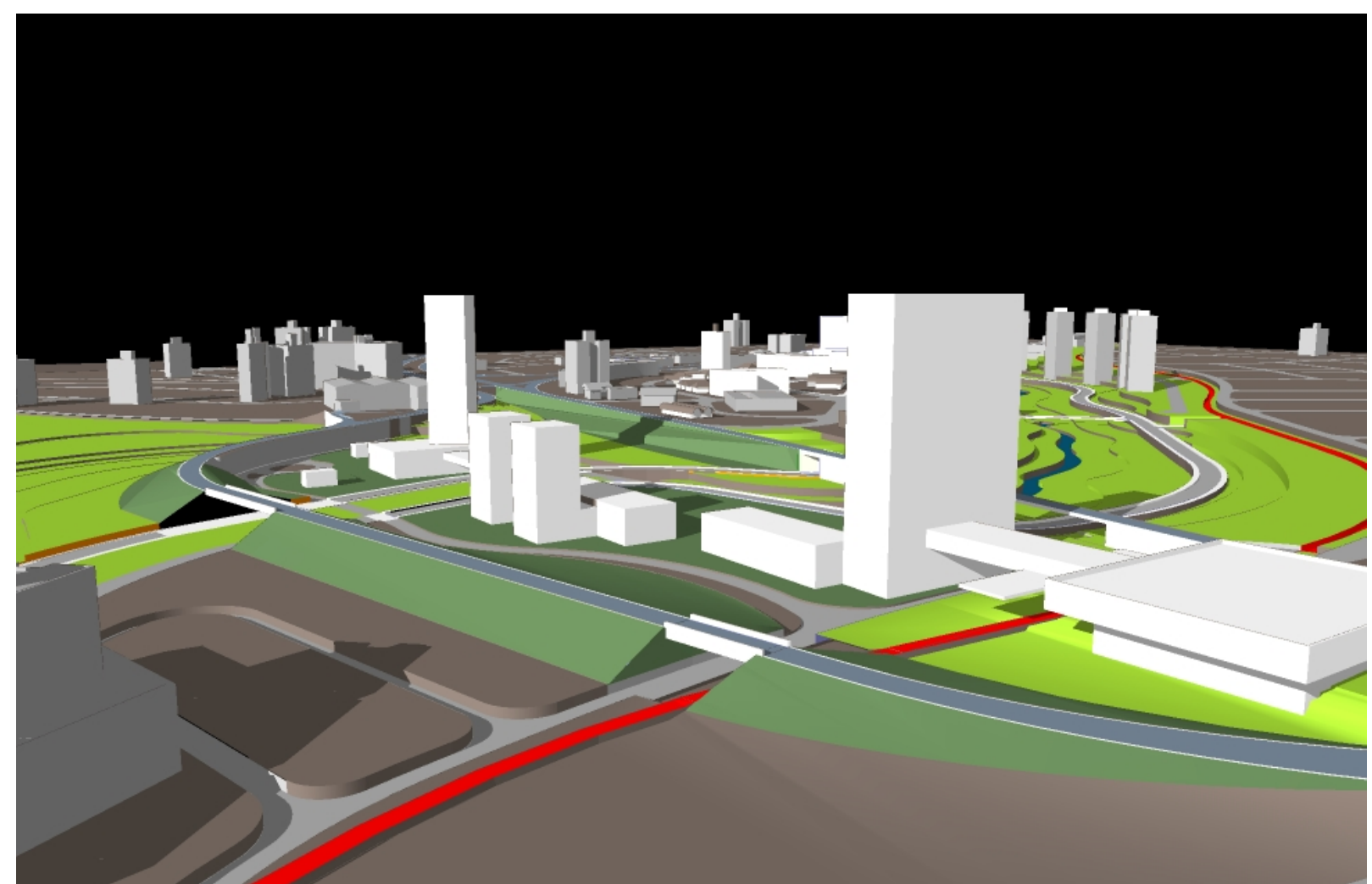

Imagem 144: Setor B - Vista geral com edificações do Centro de Negócios entre a estação Intermodal e o Centro de Eventos.

A Quadra do Centro de Negócios, têm coeficiente de aproveitamento de 1,80. São $12.948 \mathrm{~m} 2$ de terreno e $23.349 \mathrm{~m} 2$ de área total estimada de construção, divididos em 5 edificações.

O Edifício Vertical, com 21 andares somando 63 de altura, tem o pavimento tipo de $619 \mathrm{~m} 2$, perfazendo um total de $12.999 \mathrm{~m} 2$.

O Anexo, com 4 andares somando $12 \mathrm{~m}$ de altura, tem o pavimento tipo de $685 \mathrm{~m} 2$, perfazendo um total de $2740 \mathrm{~m} 2$.

O Edifício Lâmina, com 3 andares somando $9 \mathrm{~m}$ de altura, tem o pavimento tipo de $1215 \mathrm{~m} 2$, perfazendo um total de $3645 \mathrm{~m} 2$.

O Edifício $A$, com 10 andares somando $30 \mathrm{~m}$ de altura, tem o pavimento tipo de $196 \mathrm{~m} 2$, perfazendo um total de $1960 \mathrm{~m} 2$.

O Edifício $\mathrm{B}$ é igual ao $\mathrm{A}$. 


\section{QUADRA DO CENTRO DE EVENTOS - MEMORIAL CONCEITUAL}
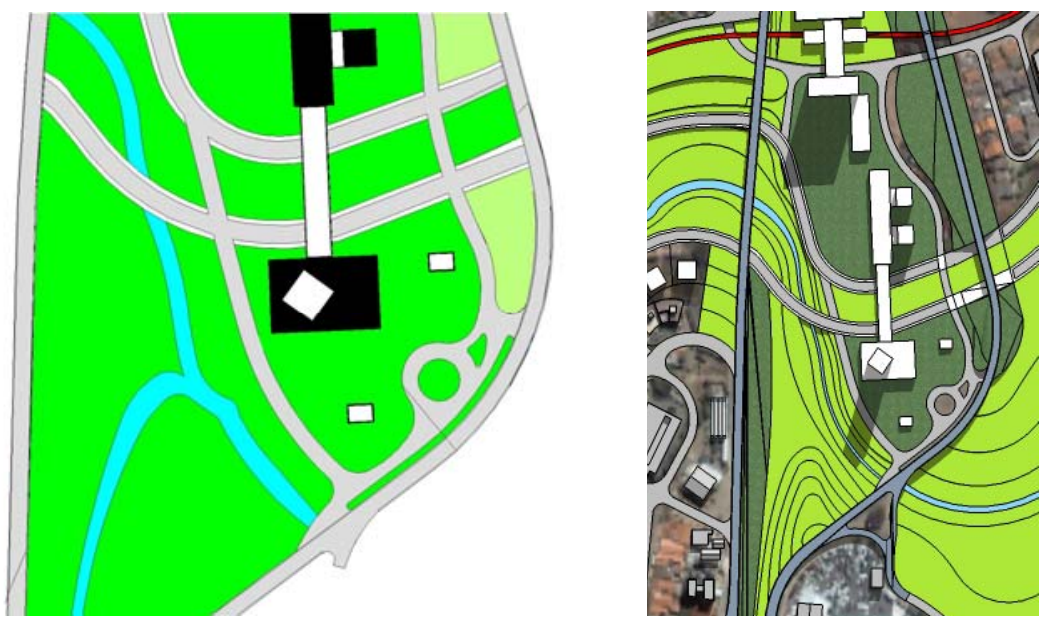

Imagem 145: Setor B - Zoom da proposta de Centro de Eventos.

A quadra do Centro de Eventos configura-se como um complexo edificado junto ao alinhamento da Avenida Parque. Constituído de Base e Torre, destaca-se visualmente no contexto geral, fator este acentuado pela rotação da torre em relação à sua base. Esta questão projetual se relaciona com o grande eixo visual criado pela Avenida Parque, caracterizado uma visão em perspectiva do conjunto. Esta implantação valoriza as áreas livres da quadra, integrando-a ao Parque Linear que a limita.

O uso proposto para a Base do complexo é o de espaço para feira de eventos, simpósios e atividades afins. A Torre, por sua vez, esta planejada como Hotel, procurando criar uma relação de uso entre os corpos do edifício, acentuado pelo caráter de acesso metropolitano da proposta em geral.

As construções ( $A$ e $B$ ) dispersas na área livre da quadra, têm uso flexível, variando de acordo com a necessidade ou evento. 


\section{QUADRA DO CENTRO DE EVENTOS - MEMORIAL DESCRITIVO}

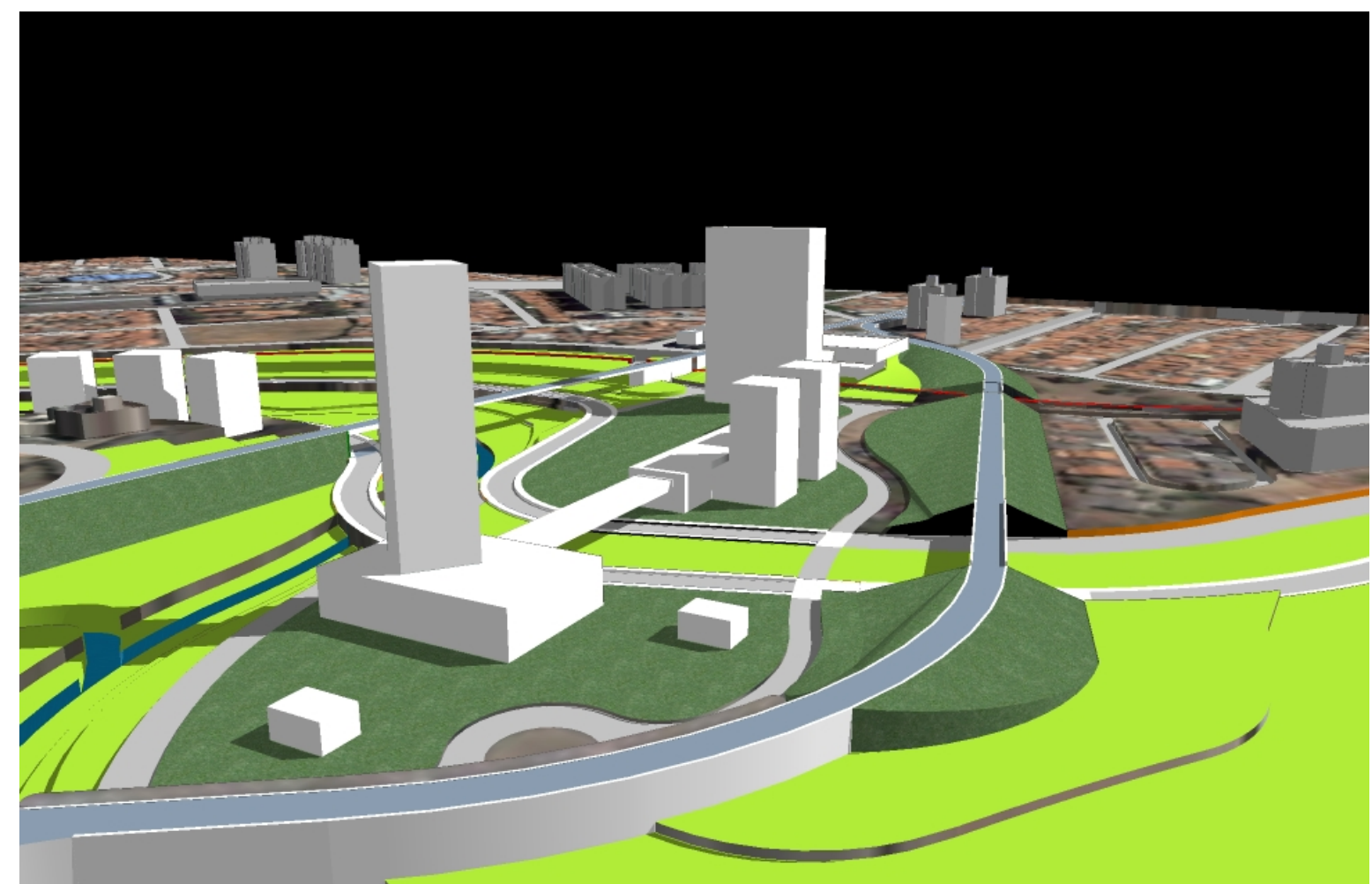

Imagem 146: Setor B - Zoom da proposta do Centro de eventos.

A Quadra do Centro de Eventos, tem coeficiente de aproveitamento de 0,91. São $6.256 \mathrm{~m} 2$ de terreno e $5.689 \mathrm{~m} 2$ de área total estimada de construção, divididos em 4 edificações.

O Complexo Centro de Eventos, possui um Edifício Base de 1100 m2, com 3 pavimentos, com altura total de $9 \mathrm{~m}$ somando $3.300 \mathrm{~m} 2$.

A torre é constituída por pavimento tipo de $225 \mathrm{~m} 2$, com 21 pavimentos, somando 63 metros de altura e uma área construída total de 4725 m2.

O Anexo A, com 2 andares somando 6 de altura, tem o pavimento tipo de $80 \mathrm{~m} 2$, perfazendo um total de $160 \mathrm{~m} 2$.

O Anexo $B$ é igual ao $A$.

A Conexão, com um andar de $3 \mathrm{~m}$ de altura, terá $644 \mathrm{~m} 2$ de área construída. 


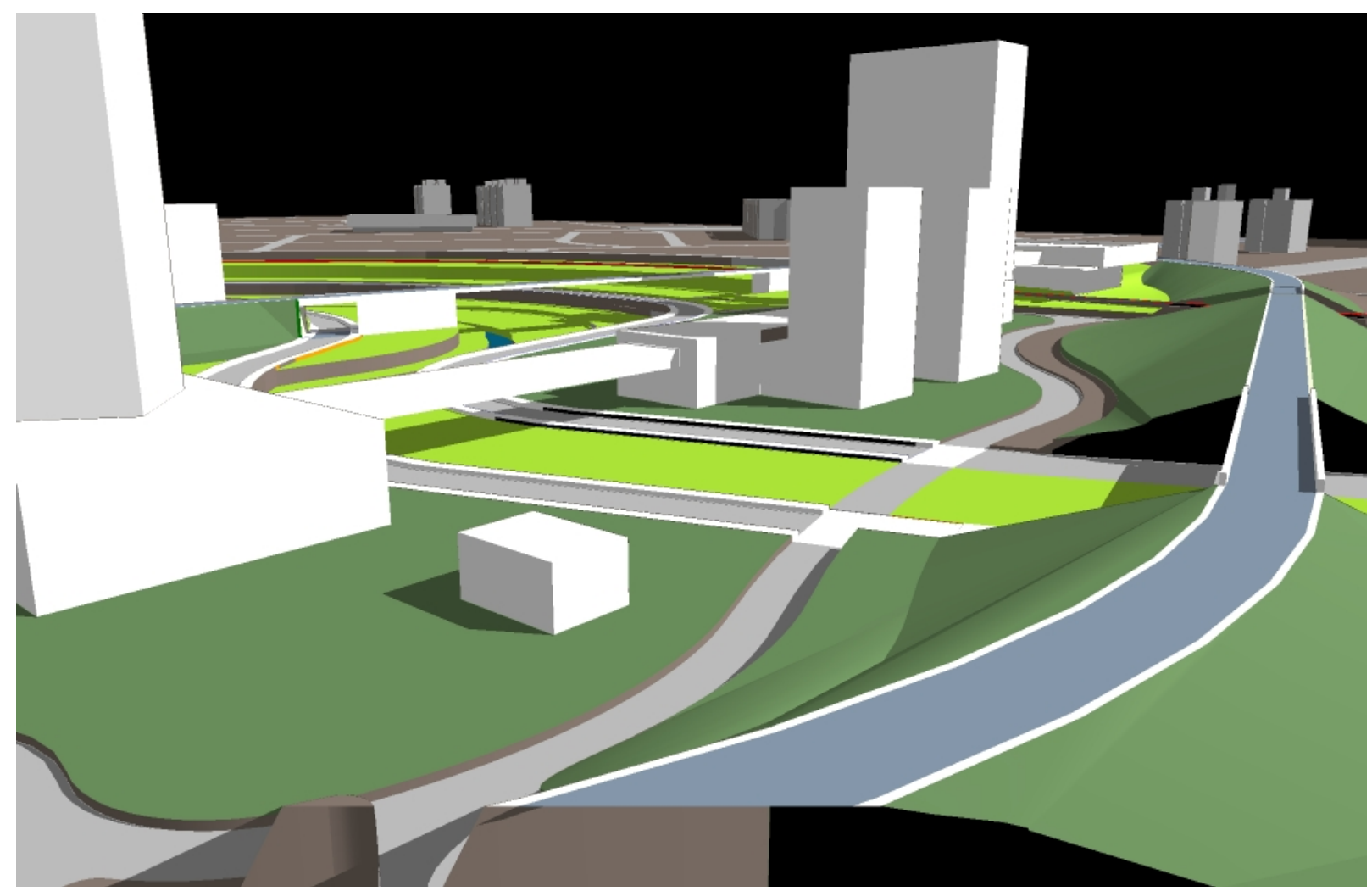

Imagem 147: Setor B - Zoom da proposta do Centro de Eventos com passarela suspensa de conexão ao Centro de Negócios.

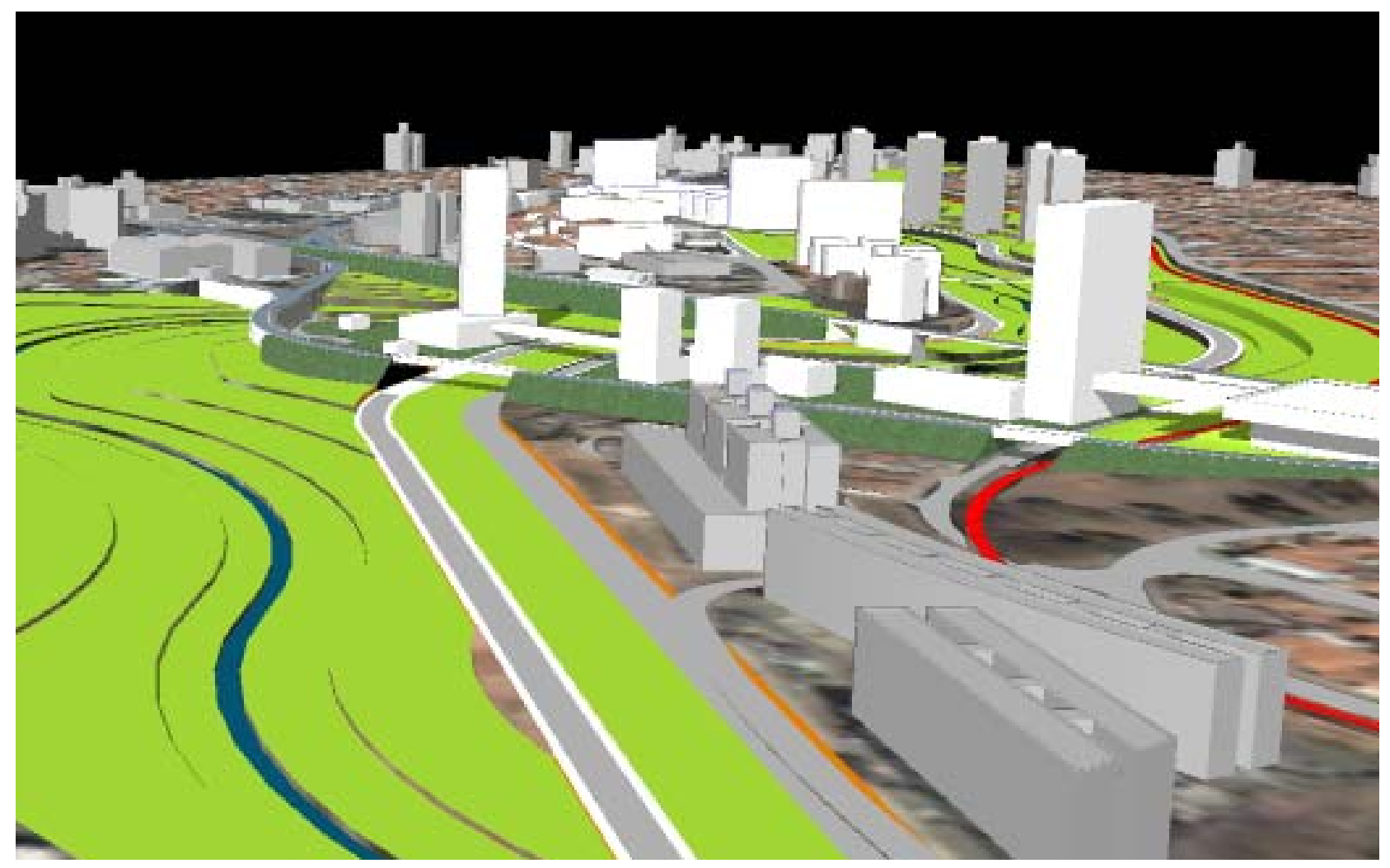

Imagem 148: Setor B - Vista geral do Setor B com a torre do Centro de Eventos (a esq) como marco visual referencial para quem esta percorrendo a nova Avenida Parque. 


\section{SETOR C - MEMORIAL CONCEITUAL}

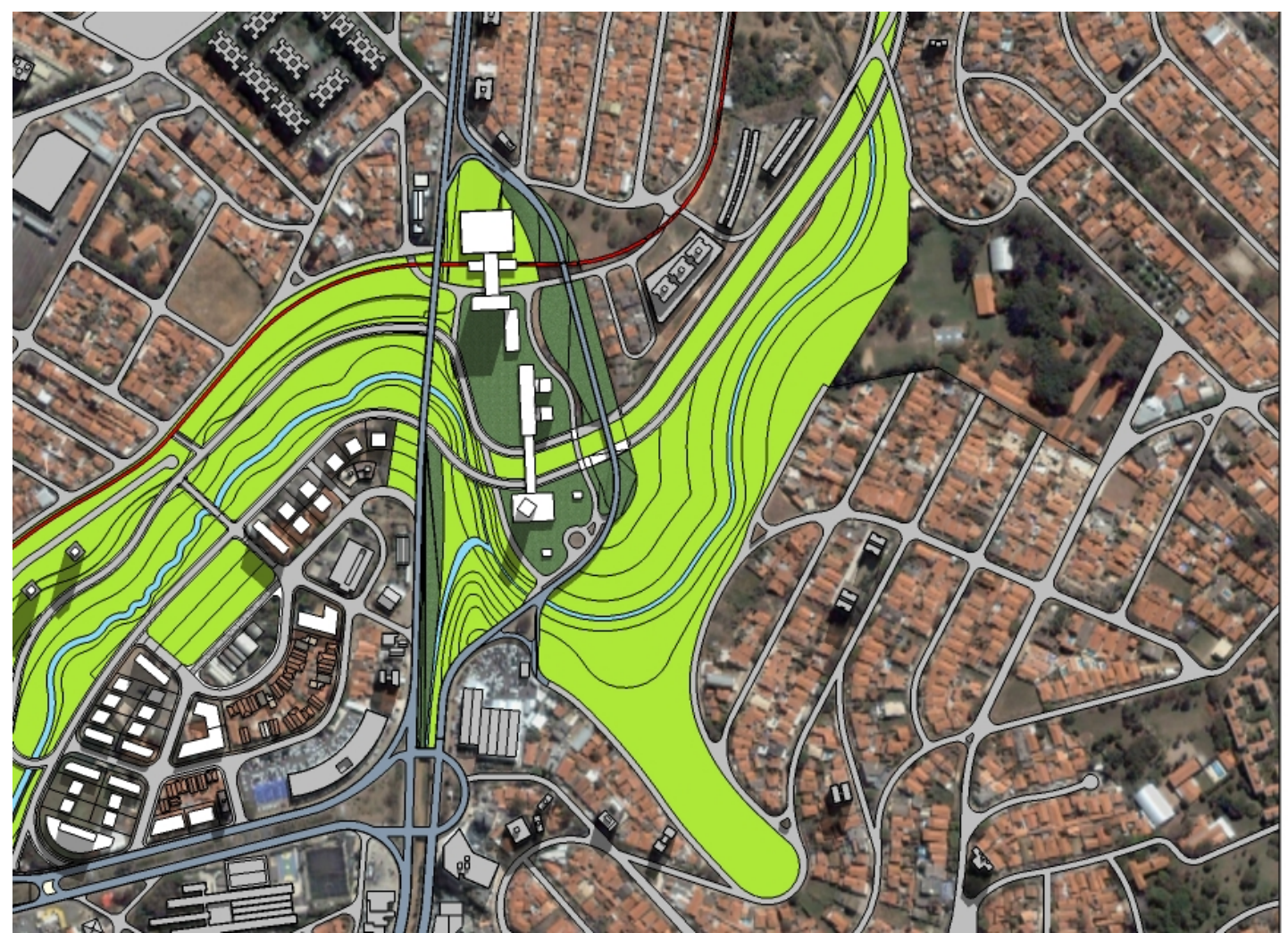

Imagem 149: Setor C - Zoom da proposta do Centro de Eventos com passarela suspensa de conexão ao Centro de Negócios.

No Setor C, a ênfase é a transformação de área ambientalmente degradada em um espaço público requalificador do entorno, com a criação do Parque Linear. Importante lembrar que o Parque Linear é trecho do sistema de Eixos Verdes, que percorre as margens do Ribeirão Anhumas como um todo.

A transição do espaço público ao espaço privado das quadras consolidadas é feita pela a Avenida Parque, limite do parque, sendo que o elemento físico que traduz essa transição é o largo canteiro central da avenida.

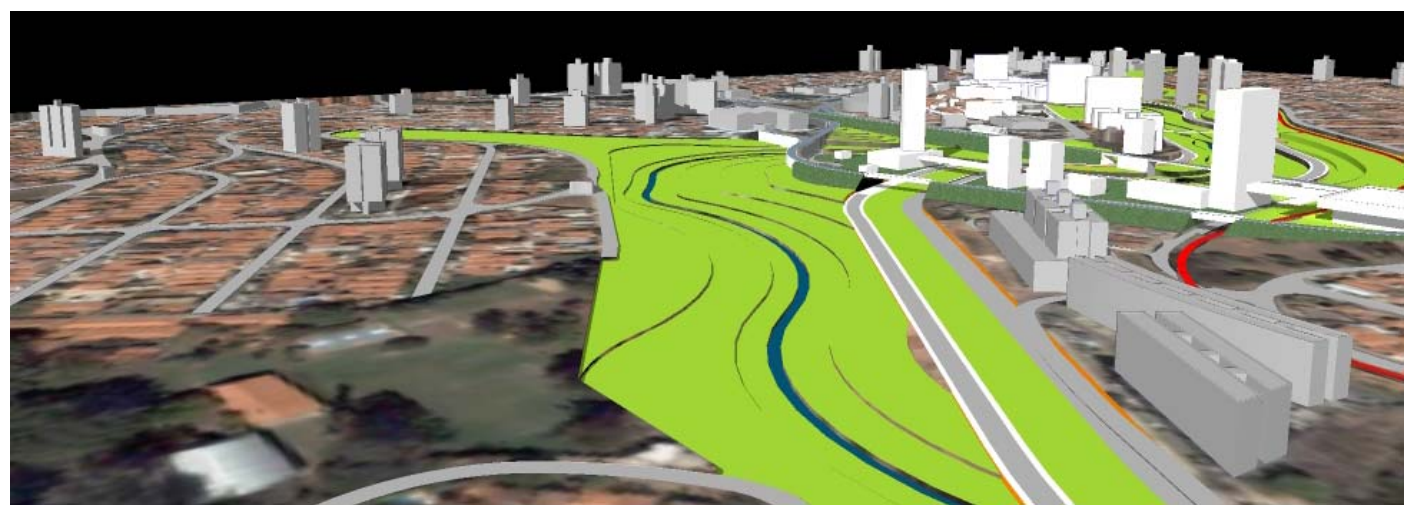

Imagem 150: Setor C - Zoom da proposta da Avenida Parque e do Parque Linear. 


\section{SETOR C - MEMORIAL DESCRITIVO}

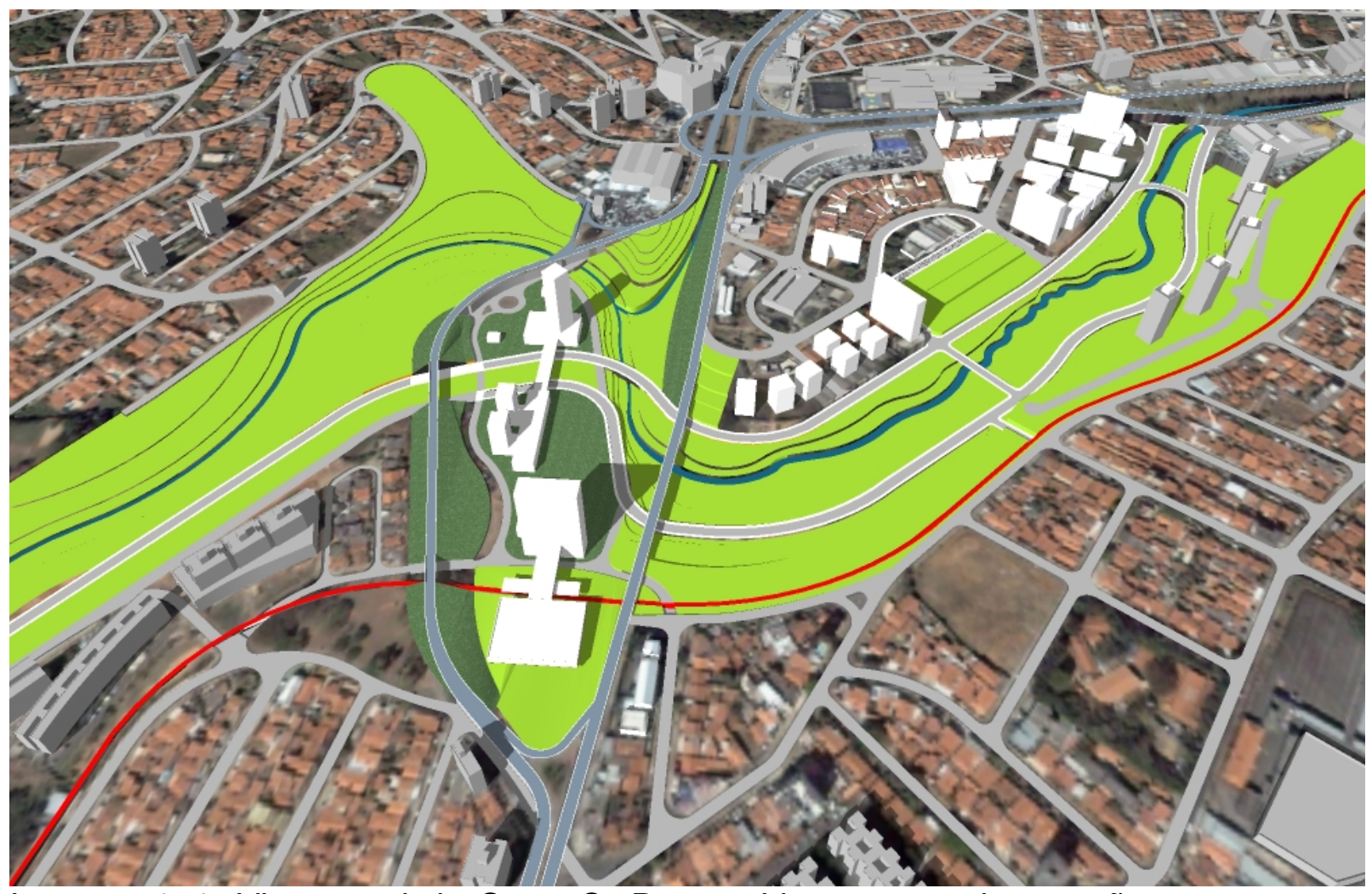

Imagem 151: Vista geral do Setor C -Parque Linear e sua integração ao contexto urbano.

O Setor C tem área total de $163.523 \mathrm{~m} 2$.

Destes, 53.986 m2 são considerados como Área Consolidada.

Os restantes $109.573 \mathrm{~m} 2$ foram objeto da proposta, sendo que 21.361 m2 foram destinados à implantação da Avenida Parque, enquanto 88.176 m2 foram destinados ao Parque Linear.
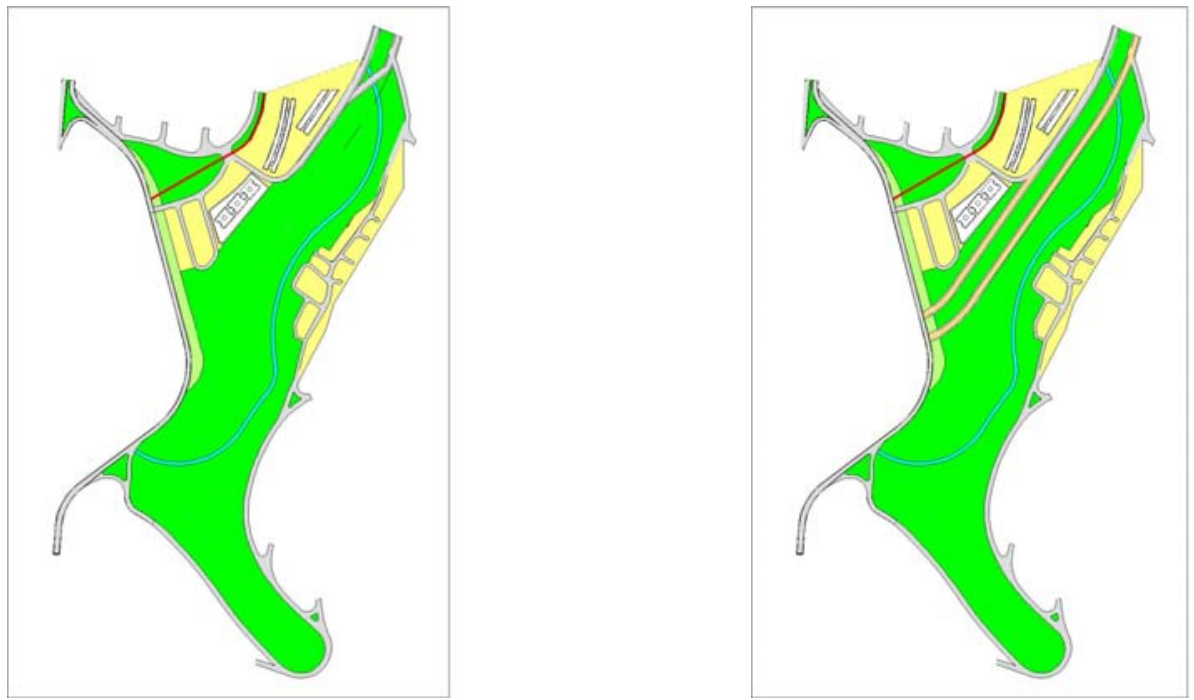

Imagem 152 e 153: Setor C - Situação atual e Situação Proposta, com sistema viário novo (cor laranja). 


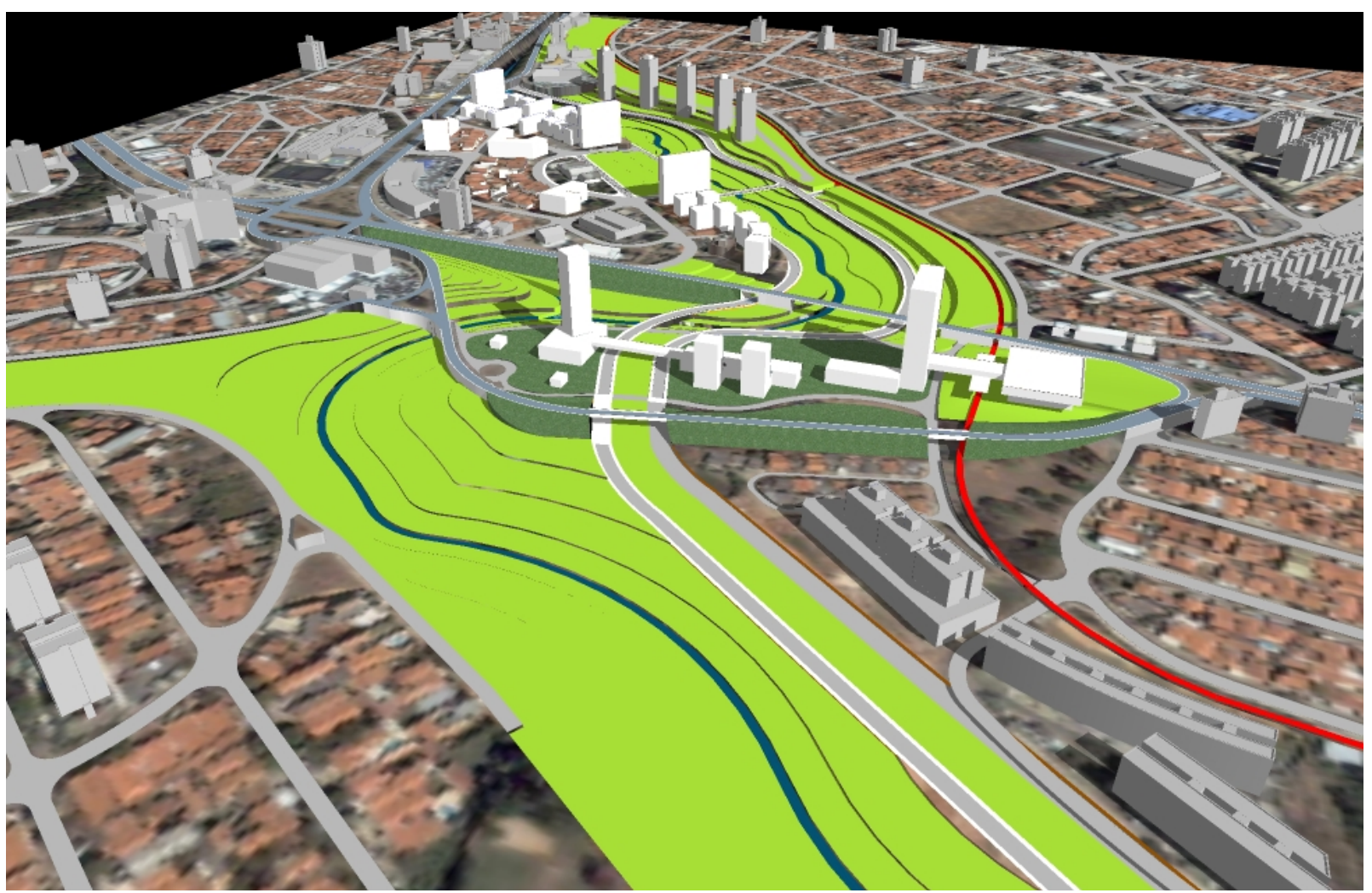

Imagem 154 e 155: Setor C - Zoom da proposta da Avenida Parque e do Parque Linear.

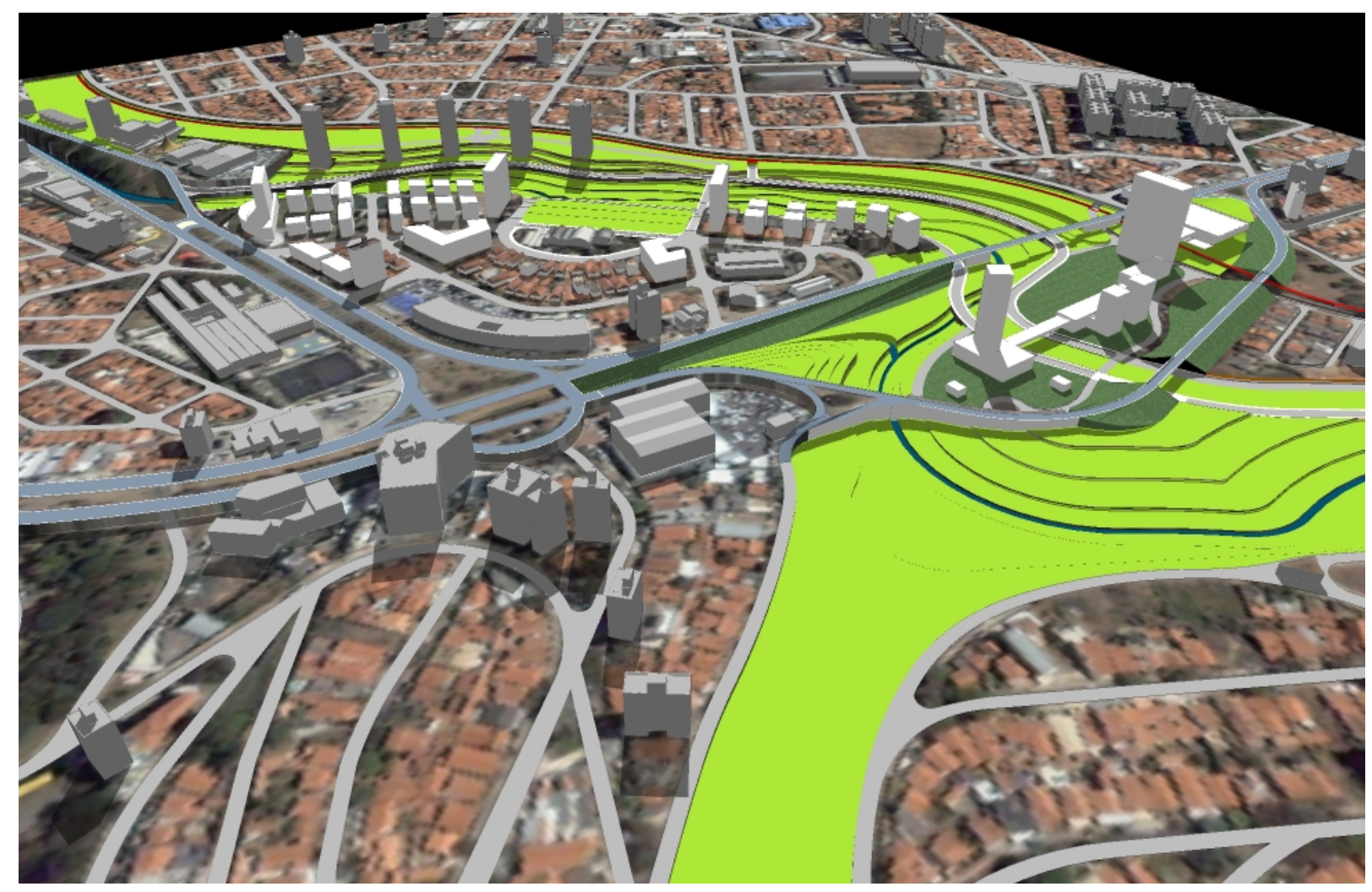

Imagem 156 e 157: Setor C - Zoom da proposta da Avenida Parque e do Parque Linear. 


\section{ANÁLISE DO USO DO SOLO}

Entendendo que o projeto urbano deve servir para a simulação de possibilidades para a área de estudo que podem servir de referência inicial ao processo de negociação entre os agentes envolvidos nos possíveis desdobramentos desta contribuição, proponho uma análise do estoque de áreas resultantes da intervenção. De acordo com a metragem de construção apresentada, o Projeto Urbano Anhumas propõe, em linhas gerais, que sejam destinados:

- $\quad 8.712 \mathrm{~m} 2$ para uso comercial (8\%)

- $\quad 23.618$ para uso habitacional (23\%)

- $\quad 32.373$ para uso serviço (30\%)

- $\quad 41.161$ para uso misto (39\%)

De maneira setorizada, lembrando que o Setor C se apresenta como Parque Linear e não apresenta edificações novas, podemos afirmar que os diferentes perfis de ocupação entre o setor A e o B se refletem nos seguintes índices:

\section{Setor A}

Os usos propostos são:

- $\quad$ Comercial $14,5 \%$

- $\quad$ Residencial 39,5\%

- $\quad$ Serviços $6 \%$

- Misto 40\%

Setor B

Os usos propostos são:

- $\quad$ Comercial 0\%

- $\quad$ Residencial 0\%

- $\quad$ Serviços $62 \%$

- Misto 38\% 


\section{Considerações}

Entendemos que os dados da análise de uso do solo são referenciais para a caracterização do perfil das intervenções, e, metodologicamente, para serem base da investigação de outras relações, que não são o foco deste trabalho, como as pesquisas e ações sócio-econômicas de definição do perfil da população diretamente destinada a ocupar os espaços disponibilizados pelo Projeto Urbano Anhumas.

Diante do raciocínio apresentado, destaca-se a contribuição do Projeto Urbano Anhumas para a criação de nova polaridade junto à estação intermodal proposta e desenvolvimento de nova centralidade linear ao longo do eixo ferroviário.

O Projeto Urbano Anhumas atende as questões legais, ambientais e sobre a urbanização dispersa, abordadas ao longo da dissertação, nas diferentes escalas, tanto metropolitana quanto local.

Essa experiência será potencializada caso essa mesma metodologia seja aplicada, guardada as especificidades de cada local, nos vazios urbanos situados ao longo dos eixos ferroviários de Campinas.

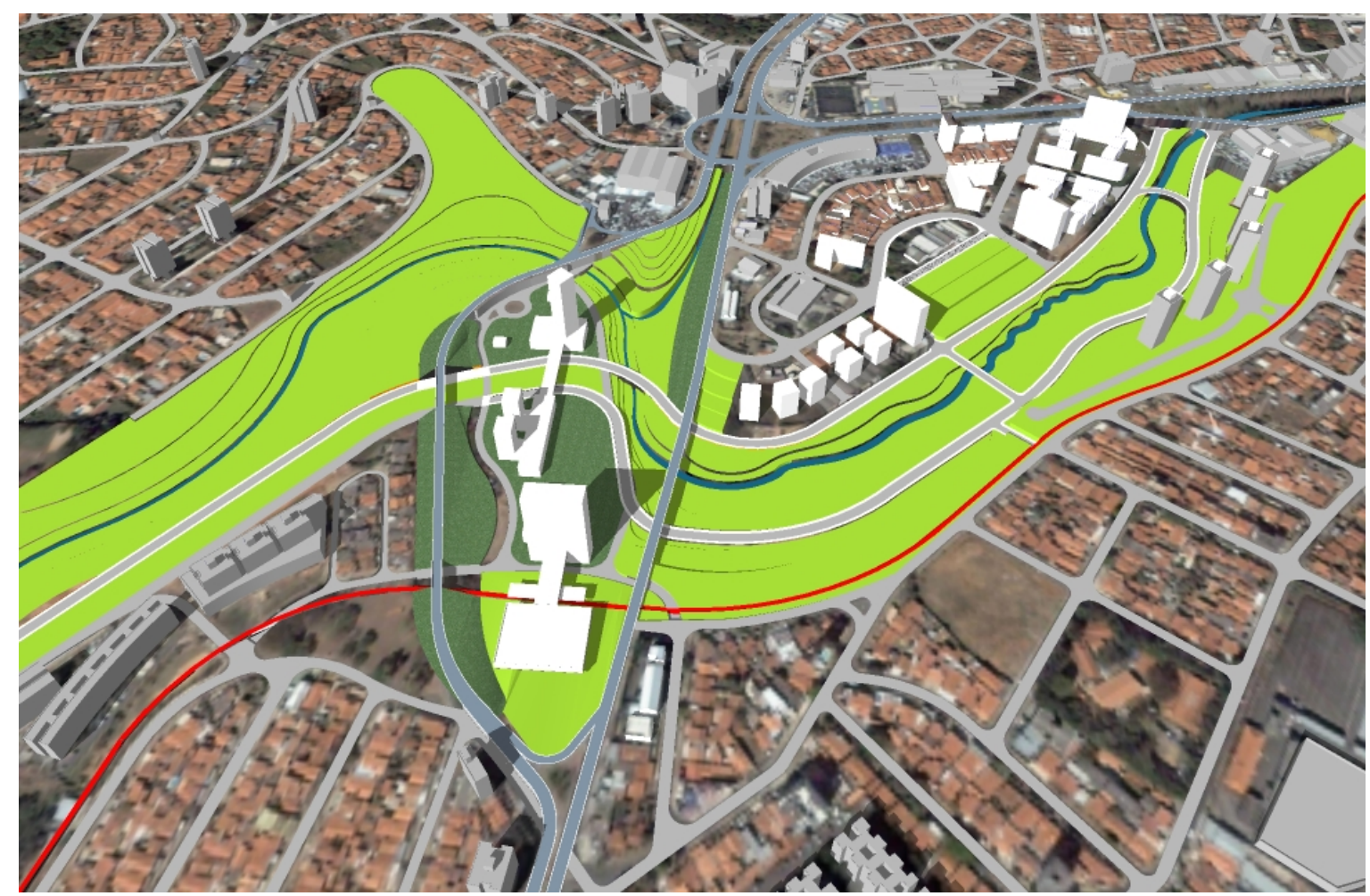

Imagem 158 Vista Geral do Projeto Urbano Anhumas. 


\section{CONCLUSÃO}

A dissertação inicialmente aborda, de forma resumida, o contexto histórico do urbanismo contemporâneo, da passagem do planejamento ao projeto urbano, através das chamadas três gerações de projeto urbano. Destaca a postura crítica da segunda geração e a nova realidade sócio-econômica dos anos 70 que se reflete nas cidades e influencia a terceira geração. Com a análise das experiências práticas internacionais e nacionais, forma-se a base teórica e prática que orientam as diretrizes propostas pelo Projeto Urbano Anhumas.

O breve histórico da cidade de Campinas embasa a análise da configuração da morfologia da área de estudo ao longo dos tempos. O perfil atual da cidade, é identificado através da leitura, em escala metropolitana, dos aspectos legais, ambientais e relativos à urbanização dispersa, estruturadores da área.

A passagem da escala metropolitana para a escala local se dá através do estudo dos mesmos aspectos, na escala da área da intervenção e fundamentam a sua setorização. Após análise das potencialidades do local é proposto um conjunto de diretrizes para o desenvolvimento e ocupação, configurados pelo Projeto Urbano Anhumas, que estabelece uma relação entre o espaço público e o privado de modo a criar uma idéia de cidade que privilegia os percursos do pedestre e na qual as diferentes escalas e funções são integradas. A proposta amplia a área livre existente e promove o adensamento através da utilização de áreas ociosas.

O Projeto Urbano Anhumas se estrutura ao longo de um parque linear configurado como espaço público às margens do ribeirão Anhumas. As quadras habitacionais são dimensionadas e ocupadas de modo a promover a integração ao tecido urbano existente, induzindo a re-qualificação do entorno. Com a implantação de uma nova Estação Intermodal, a área se integra ao sistema de transporte regional de modo a gerar uma concentração de usos comerciais e de serviços para atender o caráter metropolitano, reforçado pela proposta de Avenida Parque que conecta a área ao eixo de desenvolvimento ao longo da rodovia D. Pedro I.

Os resultados da proposta promovem a re-integração da área ao entorno e à cidade, alcançando os objetivos de melhoria da estrutura viária, de recuperação ambiental e de conexão a um sistema estruturador de transporte coletivo de massa, de modo a se configurar como uma nova centralidade que valoriza e induz o desenvolvimento da região. 


\section{REFERÊNCIAS BIBLIOGRÁFICAS}

ARANTES, Otilia Beatriz Fiori. - "O lugar da arquitetura depois dos Modernos". São Paulo: Editora da Universidade de São Paulo, 2000.

BADARÓ, Ricardo de Souza Campos. - "Campinas, o despontar da modernidade". Unicamp, 1996,Campinas.

BENEVOLO, Leonardo. 1923 - "A arquitetura no novo milênio"- tradução: Letícia Martins de Andrade. Editora Estação Liberdade, 2007.

BUSQUETS, Juan. - "Proyectos olímpicos y estrategia urbanística - Barcelona Olímpica - La ciudad renovada". Ambit Serveis Editorials S. A.

CALTHORPE, Peter. - "The next American metropolis: ecology, community, and the American dream". Princeton Architectural Press, NY, 1993.

CAMPOS FILHO, Candido Malta. - "Reinvente seu bairro: caminhos para você participar do planejamento de sua cidade" Editora 34, 2003

CHOAY, Françoise. - "O Urbanismo". Editora Perspectiva, 1965

FAROLDI, Emilio. - "Diálogos de Arquitetura”. Editora Siciliano,1997.

HALL, Peter. - "Cidades do amanhã". Editora Perspectiva, 1995, São Paulo.

HARVEY, David. - "A Condição pós-moderna”. Edições Loyola. São Paulo: 1994.

KOPP, Anatole. - "Quando o moderno não era um estilo e sim uma causa". Editora Nobel. Edusp 1990

MONTANER, Josep Maria. - "Después Del movimento moderno. Arquitectura de la segunda mitad Del siglo XX". Editorial Gustavo Gigli,1995.

. - "A modernidade superada na arquitetura, arte e pensamento do século XX". Editorial Gustavo Gigli, 2001, Versão Portuguesa: Esther Pereira da Silva, arquiteta e Carlos Munõz Gallego, jornalista.

POWELL, Keneth. - "City Transformed - Urban Architecture at the Beggining of the 21st Century". Ed. Laurence King, 2004.

REIS, Nestor Goulart. - "Estação Cultura: Patrimônio Ferroviário do povo de Campinas". Ed. Vias das Artes, São Paulo 2004. 
. - "Urbanização Dispersa e Novas Formas de Tecido Urbano". Ed. Vias das Artes, São Paulo 2006.

SOLÁ-MORALES, Ignasi de. - "Diferencias: Topografia de la arquitectura contemporânea". Editora Gustavo Gili,S. A, Barcelona.

. - "Ações estratégicas de reforço do centro". Ciclo de Palestras São Paulo, 1995.

TESES e DISSERTAÇÕES

BASSANI Jorge. - A função é a comunicação". Tese de Doutorado, FAU USP, 2005.

BELLEZA, Adriana Regina Prado. - "Arquitetura e Cidade: Recuperação e Requalificação Urbana em São Paulo. Estudos e Proposições". Dissertação de Mestrado, FAU USP, São Paulo, 2002.

MARZOLA, Nádia. - "O processo de regionalização do Estado de São Paulo a partir de 1950: Estudo de caso da região de Campinas". Dissertação de Mestrado FAU USP São Paulo, 1991.

NOBRE, Eduardo A. Cusce. - "Reestruturação econômica e território: Expansão recente do terciário na marginal do rio Pinheiros". Doutorado FAU USP Agosto de 2000-SP

PINTO, Julio Cezar Bernardes. - "Arquitetura e Lugar: Edifícios, Interstícios e Espaço Urbano". Tese de Doutorado, FAU USP, São Paulo, 2004.

SCHNEIDER, Ingrid Elisabeth. - "Confronto e dificuldades na implementação dos instrumentos urbanísticos propostos nos planos diretores municipais de Campinas na década de 90". Dissertação de Mestrado FAU USP,São Paulo, 2002.

SOUZA, Carlos Leite de. - "Fraturas Urbanas e a possibilidade de novas territorialidades metropolitanas: A Orla Ferroviária Paulistana". Tese de Doutorado, FAU USP,São Paulo, 2002. 
HECK, Eneida R. Belluzzo Godoy. - "A EMURB como instrumento de planejamento urbano em São Paulo: 1971 - 2001". Tese de Mestrado, FAU USP, São Paulo, 2004.

NUNES, Mônica Balestrin. - "A configuração espacial da várzea do rio Tietê: a região da Água Branca e as áreas municipais". Tese de Mestrado, FAU USP, São Paulo, 2004.

\section{DOCUMENTOS}

CAMPINAS, Prefeitura Municipal. Plano de Requalificação Urbana da Área Central de Campinas", 2002.

CAMPINAS, Prefeitura Municipal "Plano Diretor", 2006.

CAMPINAS, "Lei de Uso e ocupação do Solo", 1997. Campinas, Prefeitura Municipal Instituto Pólis e Câmara dos Deputados.

Estatuto da Cidade, "Guia para implementação pelos municípios e cidadãos." Brasília 2001 -- Coordenação de publicações. p. 90

TORRES, R.B; Costa, M.C.; NOGUEIRA, F.P. e PEREZ Filho, A. (coord). "Recuperação Ambiental, participação e poder público: uma experiência em Campinas". Relatório de Pesquisa 2006.

\section{REVISTAS}

REVISTA OCULUM Nº 9 - "Portzamparc e Urbanismo Contemporâneo" “PESQUISANDO E NORMALIZANDO" - Noções básicas e recomendações úteis para a elaboração de trabalhos científicos', 2004, Editora EDUFSCAR Editora da Universidade Federal de São Carlos.

REVISTA FERROVIÁRIA, Ayrton Camargo - "Seminário Trem de Aeroporto", set 2004, São Paulo. 


\section{ACERVOS PESQUISADOS}

Arquivos da Diretoria de Documentação e Informação (DIDC) da Secretaria Municipal de Planejamento e Meio Ambiente (SEPLAMA) da Prefeitura Municipal de Campinas.

Centro de Documentação da Coordenadoria Setorial do Patrimônio Cultural (CSPC) da Secretaria de Cultura da Prefeitura Municipal de Campinas

\section{SITES}

Prefeitura Municipal de São Paulo. Disponível em:

http://portal.prefeitura.sp.gov.br/empresas autarquias/emurb/operacoes urbanas/ag ua espraiada/0001/index html. Acesso em: 11 de dezembro de 2007

SALES, Pedro M. R.. "Operações Urbanas em São Paulo: crítica, plano e projetos". Parte 1 Introdução

Disponível em: http://www.vitruvius.com.br/arquitextos/arq000/esp295.asp

Acesso em 15 de dezembro de 2007.

"Operações Urbanas em São Paulo: crítica, plano e projetos. Parte 3 Operações Urbanas: plano-referência e proposições".

Disponível em: http://www.vitruvius.com.br/arquitextos/arq000/esp310.asp

Acesso em 18 de dezembro de 2007.

"Operações Urbanas em São Paulo: crítica, plano e projetos. Parte 4 Operação Urbana Butantã-Vila Sônia".

Disponível em: http://www.vitruvius.com.br/arquitextos/arq000/esp311.asp

Acesso em 18 de dezembro de 2007.

"Operações Urbanas em São Paulo: crítica, plano e projetos. Parte 5 Operação Urbana Diagonal Sul.

Disponível em: http://www.vitruvius.com.br/arquitextos/arq000/esp315.asp

Acesso em 18 de dezembro de 2007.

BERNARDINI, Marcelo M.. "Operações Urbanas em São Paulo: crítica, plano e projetos". Parte 6 - Operação Urbana Vila Leopoldina Jaguaré.

Disponível em: http://www.vitruvius.com.br/arquitextos/arq062/arq062 03.asp Acesso em 10 de dezembro de 2007.

OLIVEIRA, José G. M. de. "Operações Urbanas em São Paulo: crítica, plano e projeto". Parte 7 - Operação Urbana Carandiru - Vila Maria.

Disponível em: http://www.vitruvius.com.br/arquitextos/arq065/arq065 03.asp Acesso em 7 de setembro de 2007. 
Prefeitura Municipal de Campinas. Secretaria de Planejamento Urbano e Meio Ambiente.

Disponível em:

http://www.campinas.sp.gov.br/seplama/projetos/pqcapivari/portparqcapivari.htm

Acesso em março de 2007.

BOLETIM INOVAÇÂO UNICAMP.

Disponível em: http://www.inovacao.unicamp.br/report/news-parque.shtml.

Publicada em 14 de julho 2005

\section{HEMEROTECA}

JORNAL CORREIO POPULAR - "Área Férrea trava ocupação urbana", 04 de setembro, Campinas, 2005.

JORNAL CORREIO POPULAR - "Espólio ferroviário - Alternativas", 01 de outubro, Campinas, 2005.

JORNAL CORREIO POPULAR - "Novos pólos de desenvolvimento de Campinas". 30 de outubro, Campinas, 2005.

\section{LISTA DE IMAGENS}

Imagens 1 a 12 - Arquivos da Diretoria de Documentação e Informação (DIDC) da Secretaria Municipal de Planejamento e Meio Ambiente (SEPLAMA) da Prefeitura Municipal de Campinas.

Imagens 13 a 17 e 38 a 40 - CAMPINAS, Prefeitura Municipal "Plano Diretor", 2006.

Imagens 22 a 26 e 31 a 33 - REVISTA FERROVIÁRIA, Ayrton Camargo "Seminário Trem de Aeroporto", set 2004, São Paulo.

As demais imagens são do acervo do autor

Campinas, fevereiro de 2008.

e.mail: pedropm2001@uol.com.br 